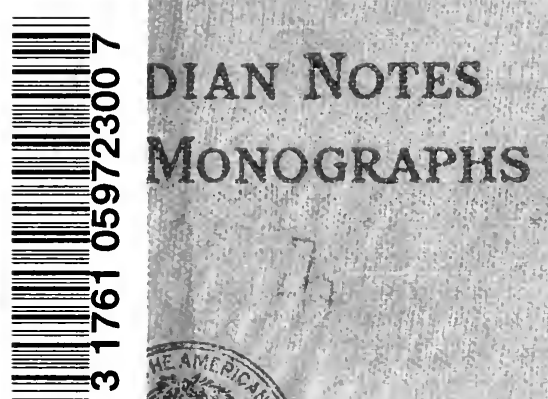




\section{INDIAN NOTES}

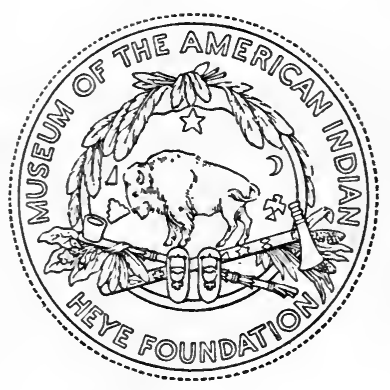




\section{A ND MONOGRAPHS}

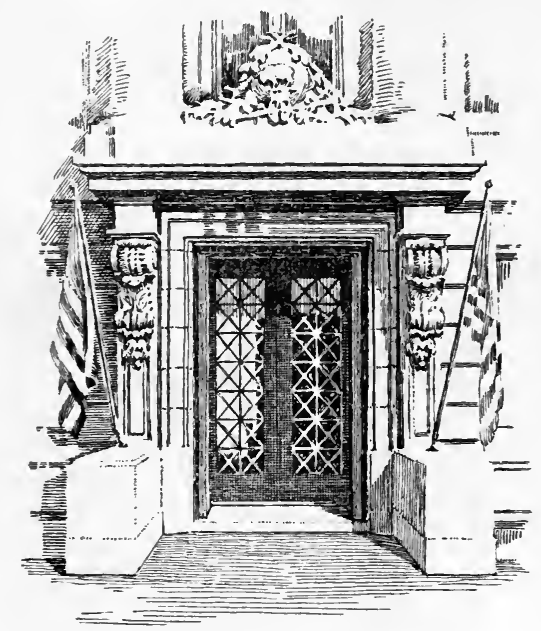

HEYE FOUNDATION 




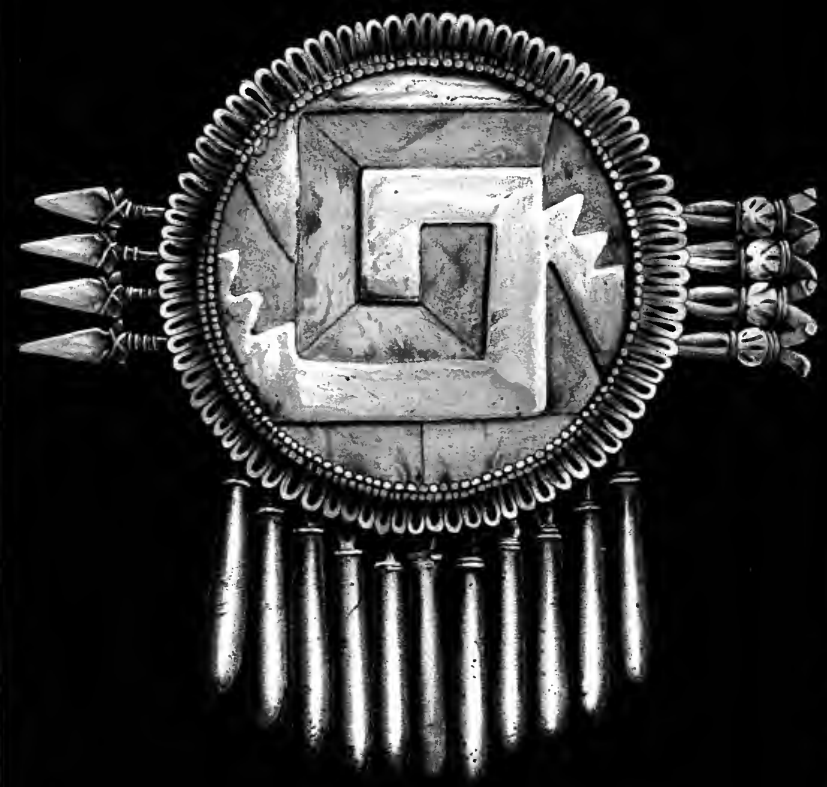


$P$

Anthrop + Ethnot

$M$

2

\section{INDIAN NOTES AND MONOGRAPHS}

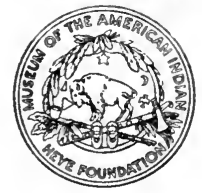

A SERIES OF PUBLICATIONS RELATING TO THE AMERICAN ABORIGINES

\section{THE GOLDSMITH'S ART IN ANCIENT MEXICO \\ BY \\ MARSHALL H. SAVILLE}

NEW YORK

MUSEUM OF THE AMERICAN INDIAN

1 HEYE FOUNDATION

1920 


\section{F \\ 1219 \\ 53}

This series of Indian Notes and MonoGRAPHS is devoted primarily to the publication of the results of studies by members of the staff of the Museum of the American Indian, Heye Foundation, and is uniform with Hispanic Notes and Monographs, published by the Hispanic Society of America, with which organization this Museum is in cordial coöperation.

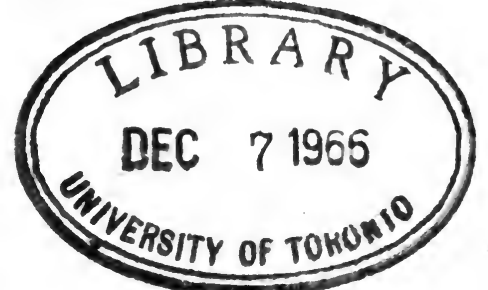

\section{5}




\section{ERRATA}

Page 7, line 8, "iron and bronze," read bronze and iron.

" 17, line 12, "for shields," read for the knees.

" 17, line 14, "head pieces," read knee guards.

" 18 , line 5 from bottom, "he brought," read he brought a woman.

“ 99, line 17, "[arenque, herring?]," read a tadpole.

" 127, line 17, "an ornament for the Huaxtecans," read a Huaxteca.

" 127 , line 22, "a serpent by means of obsidian needle points," read a serpent with obsidian points.

(To be inserted in The Goldsmith's Art in Ancient Mexico, by Marshall H. Saville, Indian Notes and Monographs.) 
Digitized by the Internet Archive in 2007 with funding from Microsoft Corporation 


\title{
THE GOLDSMITH'S ART IN ANCIENT MEXICO
}

\author{
BY \\ MARSH.ALL H. SAVILLE
}





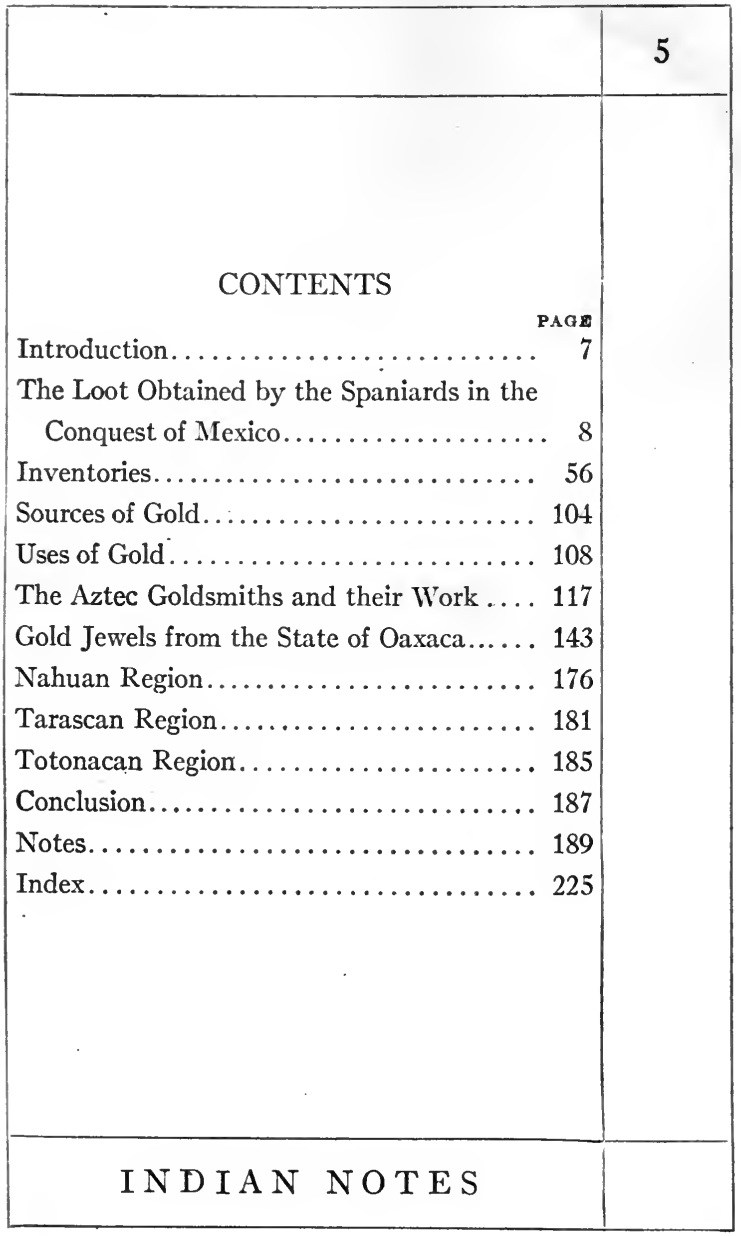


<smiles>CCCCC</smiles> 


\title{
THE GOLDSMITH'S ART IN ANCIENT MEXICO
}

\author{
By Marshall H. Saville \\ INTRODUCTION
}

archeology generally
and वIEP-T) distinguish the sequence of the stages of primitive culture by the character of the remains, based on geological stratification, and to divide the so-called stone age into several epochs, followed by the ages of (ron and bronze. This method cannot be followed in studying the remains of the ancient civilized tribes of Mexico and Central America. These tribes used chipped and polished stone implements, tools and ornaments of copper and possibly of bronze, and ornaments and idols of silver and gold, at the same time. The use of iron was un-

INDIAN NOTES 


\begin{tabular}{|l|l|}
\hline 8 & \multicolumn{1}{|c}{ G O L D S M I T H'S A R T } \\
\hline $\begin{array}{l}\text { known. This was their condition at the } \\
\text { time of the Spanish conquest, hence the } \\
\text { attempt to apply the same classification in } \\
\text { Mexican archeology as that in vogue in } \\
\text { European archeology is useless, and we must } \\
\text { look to other means to aid us in elucidating } \\
\text { the difficult problem of the rise and progress } \\
\text { of old Mexican cultures. } \\
\text { These observations at the beginning of } \\
\text { this monograph on the use of gold in ancient } \\
\text { Mexico must be borne in mind, so that we } \\
\text { may not fall into the error of judging the } \\
\text { civilization of the Mexican people by the } \\
\text { well-known method to which we have re- } \\
\text { ferred. We cannot assign any definite age } \\
\text { to the gold jewels about to be described, } \\
\text { although most of them doubtless belong to } \\
\text { the period shortly before the discovery of } \\
\text { America. It does not follow, however, that } \\
\text { gold was not known and used by these an- } \\
\text { cient tribes for many centuries. } \\
\text { THE LOOT OBTAINED BY THE SPAN- } \\
\text { IARDS IN THE CONQUEST OF MEXICO } \\
\text { The lust for gold formed one of the most } \\
\text { important factors in the conquest of Mex- }\end{array}$ \\
\hline I N D I A N N O T E S \\
\hline
\end{tabular}




\section{SPAN ISH LOOT}

ico and the exploration of New Spain. In order to extort the precious metal from the unfortunate Indians, barbarous methods were often resorted to. Peter Martyr, the first chronicler of events in the New World, commenting on conditions therein, and especially in the larger islands of the West Indies, writes that "our men's insatiable desire for gold so oppressed these poor wretches with extreme labor and toil, whereas before they lived pleasantly and at liberty, given only to plays and pastimes as dancing, fishing, fowling and hunting of little conies, that many of them perished even for very anguish of mind, the which (their unaccustomed labor) are things of themselves sufficient to engender new diseases. . . . But it shall suffice to have said thus much of the pestiferous hunger of gold. . . . The ravenous hunger of gold hath hitherto greatly hindered our men from tillage of the soil."'1

The first knowledge which the Spaniards received concerning the rich field of New Spain, was on the return of the expedition of Córdoba to Cuba in 1517, which had re-

\section{AND MONOGRAPHS}




\begin{tabular}{|c|c|}
\hline 10 & GOLDSMITH'S ART \\
\hline & $\begin{array}{l}\text { sulted in the discovery of Yucatan. }{ }^{2} \text { Ber- } \\
\text { nal Diaz, who was a member of the expedi- } \\
\text { tion, mentions that on the arrival of the } \\
\text { ships at Santiago (de Cuba), they sent on } \\
\text { shore to the Governor, "a little chest with } \\
\text { the diadems and the ducks and little fish } \\
\text { and other articles of gold and the many } \\
\text { idols. These showed such skilful workman- } \\
\text { ship that the fame of them traveled through- } \\
\text { out the Islands, including Santo Domingo } \\
\text { and Jamaica, and even reached Spain." } \\
\text { These objects must have been obtained from } \\
\text { the Maya Indians of the coast of the penin- } \\
\text { sula of Yucatan and Campeche, as Cór- } \\
\text { doba skirted the shore only from the vicinity } \\
\text { of Cape Catoche to the present state of } \\
\text { Campeche. On the receipt of these ob- } \\
\text { jects, Velasquez, the governor, determined } \\
\text { to send his nephew, Juan de Grijalva, to this } \\
\text { country in } 1518 \text { to follow up the discoveries } \\
\text { of Córdoba. Grijalva sailed around Yuca- } \\
\text { tan, and coasted the shores of southern } \\
\text { Mexico to a point between the present } \\
\text { cities of Vera Cruz and Tampico. He se- } \\
\text { cured at various places numerous gold jewels } \\
\text { either by barter or as presents from the }\end{array}$ \\
\hline & INDIAN NOTES \\
\hline
\end{tabular}




\section{SPANISH LOOT}

Indians. Regarding the treasure of gold procured by Grijalva, we have meager accounts from the two eye-witnesses who have written about the expedition, namely, Bernal Díaz, and the chaplain Juan Díaz. ${ }^{4}$ In relating what took place along the coast of the present state of Tabasco, Bernal Díaz says that in one place where they landed the Indians "spread on the ground some mats, which here they call petates, and over them a cloth, and they presented some golden jewels, some were diadems, and others were in the shape of ducks, like those in Castile, and other jewels like lizards and three necklaces of hollow beads and other articles of gold but not of much value-for they were not worth more than two hundred dollars." Chaplain Juan Díaz makes a somewhat different statement about this first barter; he writes that "they brought a mask of gilded wood and two other pieces like discs of gold of little value." He also mentions a mask of gold obtained at another place along the coast. He states that one day the cacique "told an Indian that he should clothe the Captain [Grijalva], and the Indian dressed

\section{A ND MONOGRAPHS}




\begin{tabular}{|c|c|}
\hline 12 & \multicolumn{1}{|c|}{ G O L D S M I T H' S A R T } \\
\hline $\begin{array}{l}\text { him in a corselet and some armlets of gold, } \\
\text { buskins up to the middle, and on his head } \\
\text { he put a crown of gold, only that the said } \\
\text { crown was made of very thin gold leaves."' } \\
\text { This cacique offered to give to Grijalva the } \\
\text { weight in gold of an Indian whom he had cap- } \\
\text { tured if he would release him, but this offer } \\
\text { was refused. The Indian women here were } \\
\text { described as wearing bracelets, little bells, } \\
\text { and necklaces of gold. } \\
\text { While the Spaniards were near the north- } \\
\text { ern shores of the Isthmus of Tehuantepec, } \\
\text { the following amusing incident occurred, } \\
\text { which we will quote in the words of Bernal } \\
\text { Díaz. After relating that the Spaniards } \\
\text { engaged in a brisk trade with the Indians, } \\
\text { giving them white and green glass beads } \\
\text { and other articles in exchange for jewels of } \\
\text { low-grade gold, he goes on to say: "Besides } \\
\text { these things for barter the Indians of that } \\
\text { province usually brought with them highly } \\
\text { polished copper axes with painted wooden } \\
\text { handles, as though for show or as a matter of } \\
\text { elegance, and we thought that they were } \\
\text { made of inferior gold, and began to barter } \\
\text { for them, and in three days we had obtained }\end{array}$ \\
\hline I N D I A N N O T E S \\
\hline
\end{tabular}


more than six hundred, and we were well contented thinking that they were made of debased gold, and the Indians were even more contented with their beads, but it was no good to either party, for the axes were made of copper, and the beads were valueless." $7 \mathrm{He}$ further states that at this place a sailor went to one of the temples and found a wooden chest containing many articles of gold, such as diadems and necklaces, and two idols and some hollow beads.

When the Spaniards came to the part of the Mexican coast near the present city of Vera Cruz, they found more abundant evidences of the great quantity of gold used by the Indians. Near the Island of Sacrificios, certain Indians arrived to visit the Spaniards, and they were told by the Captain that they (the Spaniards) desired only gold, to which the Indians responded that they would bring some. According to Juan Díaz, "on the following day, (they) brought gold cast into bars. The Captain told them to bring more. The next day they came with a very beautiful mask of gold, a small figure of a man wearing a little

\section{A N D MONOGRAPHS}




\begin{tabular}{|c|c|}
\hline 14 & GOLDSMITH'S ART \\
\hline & $\begin{array}{l}\text { mask, and a crown of gold beads, and other } \\
\text { jewels and stones of divers colors. Our } \\
\text { men asked them for some native gold, and } \\
\text { the Indians showed them some and told } \\
\text { them that it came from the foot of the coast } \\
\text { range, because it was found in the rivers } \\
\text { which had their source in the mountains. } \\
\text { An Indian could leave here and reach the } \\
\text { source by midday, and have time before } \\
\text { dark to fill a reed as thick as a finger. In } \\
\text { order to get the gold they had to go to the } \\
\text { bottom of the water and fill their hands with } \\
\text { sand in which they searched for the grains, } \\
\text { which they kept in their mouths. From } \\
\text { the foregoing it is believed that there is } \\
\text { much gold in this country. These Indians } \\
\text { melted the gold in a crucible, in whatever } \\
\text { place they found it, making use of cane } \\
\text { reeds as bellows to light the fire. We saw } \\
\text { them do this in our presence." } \\
\text { On the return of Grijalva to Cuba, the } \\
\text { Spaniards living there were much excited } \\
\text { over the gold obtained by the expedition. } \\
\text { No doubt Grijalva made an official report, } \\
\text { and it is evidently this report which was } \\
\text { used by Oviedo in the extended account of }\end{array}$ \\
\hline & INDIAN NOTES \\
\hline
\end{tabular}




\begin{tabular}{|l|}
\hline S P A N I S H L O O T \\
\hline this expedition included in his history. \\
Governor Velasquez must have made an \\
inventory of the treasure which he remitted \\
to the King of Spain, and this is probably \\
the list published by López de Gomara, ${ }^{10}$ a \\
translation of which follows: \\
The Barter that was got by Juan de Grijalva \\
Juan de Grijalva obtained by barter with \\
the Indians of Potonchan, San Juan de Ulúa \\
and other places of that coast, so much and so \\
many things, that those of his company cher- \\
ished the wish to remain there, and for the little \\
price that [they paid] they took pleasure to ex- \\
change with them as much as they [the Indians] \\
brought. The work of many of them [the things \\
brought] was worth more than the material. He \\
got, in fine, the following: \\
A little hollow idol of gold. \\
Another idol of the same [material], with \\
horns, and long hair, which has a necklace on \\
the neck, a fan in the hand, and a small stone \\
in the navel. \\
One like a disc of thin gold with some stones \\
inlaid. \\
A helmet of gold with two horns, and a switch \\
of long black hair. \\
Twenty-two ear-rings of gold, each with three \\
pendants, of the same [material]. \\
Other smaller ear-rings of gold. \\
Four very wide bracelets of gold. \\
A delicate head-band of gold. \\
\hline A N D M O N O G R A P H S \\
\hline $\begin{array}{l}\text { A } \\
\text { A }\end{array}$ \\
\hline
\end{tabular}

I. N. M. -2 


\begin{tabular}{|c|c|}
\hline 16 & GOLD S M I TH'S A R T \\
\hline & $\begin{array}{l}\text { A necklace of hollow gold beads, with a very } \\
\text { well made frog among them. } \\
\text { Another necklace of the same [kind], with a } \\
\text { little lion of gold. } \\
\text { A pair of drop ear-rings. } \\
\text { Two eaglets of gold, well cast. } \\
\text { A small saucer of gold [that weighed six } \\
\text { ounces, Bustamante edition]. } \\
\text { Two drop ear-rings of gold and turquoises, } \\
\text { each with eight pendants. } \\
\text { A woman's necklace ot twelve pieces [each] } \\
\text { with twenty-four pendants of stones. } \\
\text { A large gold collar. } \\
\text { Six small collars of thin gold. } \\
\text { Seven other collars of gold with stones } \\
\text { Four drop ear-rings of gold leaf. } \\
\text { Twenty fish-hooks of gold with which the } \\
\text { fished. } \\
\text { Twenty grains of gold which weighed fifty } \\
\text { ducats. } \\
\text { A braid of gold. } \\
\text { Small thin slabs of gold. } \\
\text { An olla of gold. } \\
\text { A thin hollow idol of gold. } \\
\text { Some delicate poniards of gold. } \\
\text { Nine hollow gold beads, with their ends. } \\
\text { Two strings of gilded beads. } \\
\text { Another string of gilded wood [beads], with } \\
\text { little gold quills. } \\
\text { A small gold cup with eight purple stones } \\
\text { and twenty-three of other colors. } \\
\text { A mirror with two faces, adorned with gold. } \\
\text { Four gold bells. } \\
\text { A small thin saucer of gold. } \\
\text { A small gold canister. }\end{array}$ \\
\hline & I N D I N NOTES \\
\hline
\end{tabular}


Certain small necklaces of gold, of little value, and some small pendant ear-rings of base gold.

One like an apple (manzana) of hollow goild.

Forty hatchets of gold with a mixture of copper, that were worth as much as twentyfive hundred ducats.

All the pieces needful for arming a man, of thin gold.

An armor of wood with gold leaf, and [inlaid with] small bits of black stones.

$A$ head-dress of leather and gold.

Four armors of wood for tht fits, covered with gold leaf.

Two large heat piefes of wood, [covered] with gold leaves.

Two shields, covered with many fine colored feathers.

Other shields of gold and feathers.

A large colored feather piece, with a small bird of natural size in the center.

A fan of gold and feathers.

Two fans of feathers.

Two small pitchers of alabaster, filled with divers stones, somewhat fine, and among them one of the value of two thousand ducats.

Certain beads of tin.

Five necklaces of round clay beads covered with very thin gold leaf.

One hundred and thirty hollow gold beads.

Many other necklaces of gilded wood and clay [beads].

Many other gilded beads.

Some tijeras [possibly tiraderas, throwingsticks], of gilded wood.

Two gilded masks.

A mosaic mask with gold.

\section{A N D MONOGRA P H S}




\begin{tabular}{|c|c|}
\hline 18 & G OL D S I T H'S ART \\
\hline$=$ & $\begin{array}{l}\text { Four masks of gilded wood, one of which } \\
\text { has two straight rods of mosaic with small bits } \\
\text { of turquoise, and another [with] the ears of the } \\
\text { same, although with more gold. } \\
\text { Another was a mosaic of the same as the } \\
\text { nose above, and the other as the eyes above. } \\
\text { Four plates of wood, covered with gold leaf } \\
\text { [or jicaras like great dishes of large calabashes, } \\
\text { Bustamante edition]. } \\
\text { A head of a dog covered with stone mosaic- } \\
\text { work. } \\
\text { Another head of an animal of stone adorned } \\
\text { with gold with its crown and crest, and two } \\
\text { pendants which were all of more delicate gold. } \\
\text { Five pairs of shoes like rope-soled sandals. } \\
\text { Three red skins. } \\
\text { Seven flint knives for [use in] sacrificing. } \\
\text { Two small wooden painted shields, and a jar. } \\
\text { A very handsome doublet with short sleeves, } \\
\text { of colored feathers. } \\
\text { Something like a wrapper of fine cotton } \\
\text { [cloth]. } \\
\text { A large mantle of fine feathers. } \\
\text { Many mantles of delicate cotton [cloth]. } \\
\text { Many other mantles of coarse cotton [cloth]. } \\
\text { Two hoods or Moorish veils, of good cotton } \\
\text { [cloth]. } \\
\text { Many pinetes [pevetes, Bustamante cdition] } \\
\text { of soft colors. } \\
\text { Much aji (peppers) and with other fruits. } \\
\text { Besides this he brought' } \\
\text { him, and certain was gives given man whom he had } \\
\text { taken. For one of the men he had been offered } \\
\text { his weight in gold, but he would not take it. } \\
\text { He also brought news that there were Amazons }\end{array}$ \\
\hline & I N I A N NOTES \\
\hline
\end{tabular}




\section{S P A N I S L OOT}

in certain islands, and many believed it, surprised at the barter which he brought at such sordid price: because all of it had cost not more than six shirts of coarse linen, five kerchiefs, three common breeches, five women's shoes, five wide belts of leather worked with spun colors with their bags, many little bags of sheepskin, many laces of one and two ferrules six satinwood mirrors, four glass plaques, two thousand green glass beads, which they much appreciated, one hundred necklaces of manycolored beads, twenty combs which they valued highly, six scissors. which they were pleased with, fifteen large and small knives, one thousand sewing needles, two thousand pins, eight sandals, some pliers, a hammer, seven colored hoods, three large coats with colored strips, a coat of frieze with a hood, and a threadbare loose garment of black velvet, with a cap of black velvet.

Peter Martyr, in the Fourth Decade of his De Orbe Novo, first printed in 1521, in describing the voyage of Grijalva; writes that: "Off the coast of Yucatan and well on the way from the island of Cozumel, the Spaniards encountered a canoe filled with fishermen. There were nine of them, and they fished with golden hooks."11

These are probably the hooks mentioned in the above list. No specimens of

\section{A N D MONOGRAPHS}




\begin{tabular}{|l|l|}
\hline 20 & \multicolumn{1}{|c|}{ G O L D S M I T H S A R T } \\
\hline $\begin{array}{l}\text { gold fish-hooks from Mexico are known to } \\
\text { the writer, although they are common } \\
\text { enough from the Ecuadorian and Colombian } \\
\text { coasts. }{ }^{12} \\
\text { Velasquez now resolved to send another } \\
\text { expedition to establish a permanent settle- } \\
\text { ment in the new country, and in 1519 it set } \\
\text { forth from Cuba under command of Hernan } \\
\text { Cortés. After the arrival of the Spaniards } \\
\text { on the coast of Vera Cruz, the Indians were } \\
\text { not long in ignorance of the consuming } \\
\text { thirst of the conquerors for gold. In order } \\
\text { to placate the formidable strangers, with } \\
\text { childlike confidence that by giving them } \\
\text { their wish the invasion of his dominions } \\
\text { would be averted, Montezuma sent rich } \\
\text { presents to Cortés through Tendile (Teuh- } \\
\text { tlile), governor of Cuetlaxtla (the modern } \\
\text { Cotastla), which was then subject to the } \\
\text { Aztecs. When all this treasure thus } \\
\text { brought together was ready to be sent to } \\
\text { Spain, with the report of the voyage, an } \\
\text { inventory or list of the objects was drawn } \\
\text { up and despatched with two special mes- } \\
\text { sengers, Alonso Portocarrero and Francisco } \\
\text { de Montejo, who were charged to deliver }\end{array}$ \\
\hline I N D I A N N O T E S \\
\hline $\begin{array}{l}\text { and } \\
\text { and }\end{array}$
\end{tabular}




\section{SPAN ISH LOOT}

the treasure to the King. These valuable gifts have been briefly described by several members of the expedition who saw them before they left Mexico, and on their receipt in Spain they were described by various other chroniclers. ${ }^{13}$

We present a translation of the important inventory, ${ }^{14}$ with certain valuable notes made by Mora in his edition of the work of Clavigero.

"Report of the Jewels, Shields, and Clothing sent to the Emperor Charles the Fifth by Don Fernando Cortés and the Town Council of Vera Cruz with their Proctors Francisco de Montejo and Alonso Hernandez Portocarrero.

"That which is contained in this repcrt is of the greatest interest, because it manifests what was the state of the fine arts of the Mexicans before they had any communication with the Europeans. D. Juan Muñoz collated, on March 30, 1784, the report which follows of the presents sent from New Spain, with another which he found in the book called Manual del Tesorero of the Casa de la Contratacion of Seville, and of this latter manuscript are the variants which we place at the foot. [Given here as footnotes.]

\section{A ND MONOGRAPHS}




\begin{tabular}{|c|c|}
\hline 22 & GOLDSM I TH'S A R T \\
\hline$:$ & 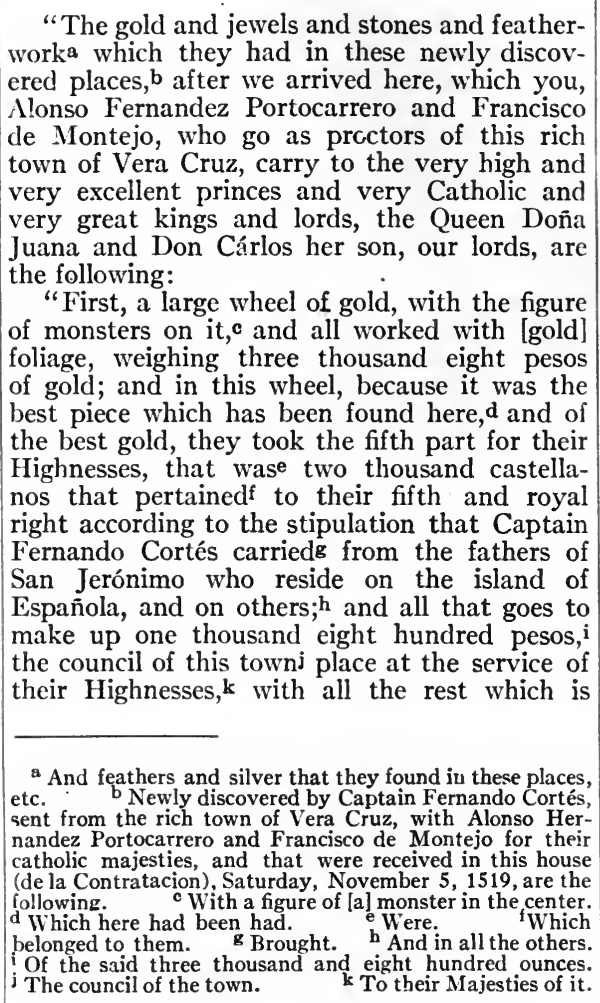 \\
\hline & I N I A N NOTES \\
\hline
\end{tabular}




\section{SPAN ISH LOOT}

contained in this report, which belonged to those of this said town.a

"Item: two collarsb of gold and stone mosaicwork (precious stones), one of which has eight strings, and in them two hundred and thirty-two red stones, and one hundred and sixty-three green stones; and hanging from the said collard from the border of it twenty-seven gold bells, and in the center of them there are four figures of large stones sete in gold, and from each one of the two in the center ${ }^{f}$ hang simple pendants, $\mathrm{g}$ and of those at the endsh each [has] four doubled pendants. ${ }^{i}$ And the other collar hasj four strings that have one hundred and two red stones and one hundred and seventy-two stones that appear to have a green color, and around the said stones twenty-six gold bells, and in the said collar ten large stones set in gold, from which hang one hundred and forty-two pendantsk of gold.

"Four pairs of antiparras (leggings), two pairs being of delicate gold leaf, with a trimming of yellow deerskin, and the other two [pairs], of thin silver leaf, with a trimming of white deerskin, ${ }^{1}$ and the others of featherworkm of divers colors, and very well made, from each one of which hang sixteen gold bells, and all trimmed with red deerskin.

"Another item: a hundred ounces of gold

a Which belongs to them. collars. the said collar. That the one of them.

b Another item: two large one. the two. ${ }^{g}$ Hang seven pendants.

$k$ Pendants.

i Pendants.

$f$ And in the hang from

$m$ And the rest of feather-work.

$h$ And in the ends of $j$ And one of them. 1 of white deer [skin] the trimming.

\section{AND MONOGRAPHS}




\begin{tabular}{|c|c|}
\hline 24 & GOLDSMITH'S ART \\
\hline & 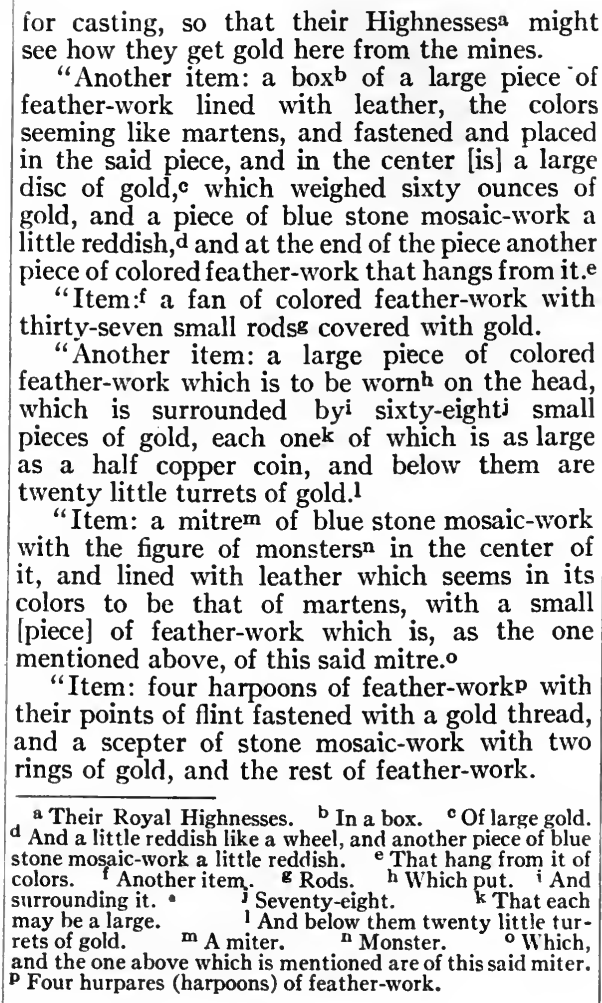 \\
\hline & I N I A N NOTES \\
\hline
\end{tabular}




\section{S P A N I H L OOT}

"Item:a an armlet of stone mosaic-work, and furthermore, a piece of small black featherwork $\mathbf{b}$ with other colors.

"Item: a pair of large sandals of colored leatherc that appears like martens, the soles white, sewed with threads of gold.d

"Furthermore: a mirror placed in a piece of blue and red stone mosaic-work with featherwork stucke to it, and two strips of red leather stuck $f$ to it, and another skin that seemsg like those martens.

"Item:h three colored [pieces] of featherwork, which are (pertain to) a large gold head like a crocodile.

"Item: some leggings of bluei stone mosaicwork, lined with leather, of which the colors seemj like martens; on each onek of them [there are] fifteen gold bells.

"Item:1 a maniple (standard) of wolf-skin, with four strips of skin like martens.

"Furthermore: some fibersm placed in [the quills of] colored feathers, and the said fibers are white, and appearn like locks of hair.

"Item:o two colored [pieces of] featherwork which are for two [pieces of] head armorp of stone mosaic-work, which is mentioned further on.

another item.

b of feathers.

a pair of shoes of a skin which in its colors looks like, etc. d Some small tiritas (bands) of gold. e Stuck. f Stuck. $\mathrm{g}$ Which appear. ${ }^{\mathrm{h}}$ Another item. more, some leggings of blue stone-mosaic. $j$ Appear. $\mathrm{k}$ With each. more in some barbas (fibers). ${ }^{n}$ And appear. o Another item. $\quad$ capacetes (head armor).

\section{A ND MONOGRAPHS}




\begin{tabular}{|c|c|}
\hline 26 & GOL D S M I TH'S A R T \\
\hline & $\begin{array}{l}\text { "More, two other [pieces of] colored feather- } \\
\text { work which are for two pieces of gold which } \\
\text { they weara on the head, made likeb great shells. } \\
\text { "More, two birds of green feathers with } \\
\text { their feet, beaks, and eyes /made] of gold, which } \\
\text { are put in a piece of one of those shell-like pieces } \\
\text { of gold.c } \\
\text { "More, two guariques (ear ornaments) of } \\
\text { blue stone mosaic-workd which are to be put } \\
\text { in the big head of the crocodile. } \\
\text { "In another square box a head of a large } \\
\text { crocodile of gold, which is the one spoken of } \\
\text { above, where the said piecese are placed. } \\
\text { "More, another head armorf of blue stone } \\
\text { mosaic-work withg twenty gold bells which } \\
\text { hang pendent at the border, with two stringsh } \\
\text { of beads which are above each bell, and two } \\
\text { guariques of wood with two plates of gold. } \\
\text { "More, a birdj of green feathers, and the } \\
\text { feet, beak, and eyes of gold. } \\
\text { "Item: another head armork of blue stone } \\
\text { mosaic-work with twenty-five gold bells, and } \\
\text { two beads of gold above each bell, that hang } \\
\text { around it with somel guariques of wood with } \\
\text { plates of gold, and a bird of green plumage } \\
\text { with the feet, beak, and eyes of gold. } \\
\text { "Item: in an haba of reed two large pieces } \\
\text { of gold which they put on the head, which are } \\
\text { made like a gold shell with their guariques of } \\
\text { wood and plates of gold, and besides, two birds } \\
\text { a Which are worn. } \\
\text { lacking in the Sevillian manuscript. } \\
\text { e For which are the pieces. } \\
\text { g In. } \\
\text { canada (pendentth two beads. } \\
\text { k Capacele (head armor). }\end{array}$ \\
\hline & INDIAN NOTES \\
\hline
\end{tabular}




\section{SPA N ISH LOOT}

of green plumage, with their feet, beaks, and eyes of gold.a

"Moreover: sixteen shields of stone mosaicwork, with their colored feather-work hanging from the edge of them, $b$ and a wide-angled slab with stone mosaic-work with its colored featherwork, and in the center of the said slab, made of the said stone mosaic-work, a cross of a wheelo which is lined with leather, which has the color of martens.

"Again, a scepter of red stone mosaic-work, made liked a snake, with its head, teeth, and eyes from what appears to be mother-of-pearl, and the hilt is adorned with the skine of a spotted animal, and below the said hilt hang six small pieces of feather-work.

"Another item: a fanf of feather-work, placed in a reed adorned with the skin of a spotted animal, after the manner of a weathercock, and above it has a crown of feather-work, and finallyg has all over it long green feathers.

"Item: two birds madeh of thread and featherwork, having the quills of their wings, tails, and the claws of their feet, and the eyes and the ends of the beaks made of gold, $i$ placed in respective reeds, covered with gold, and below some feather down, one white, the other yellow, $\mathbf{j}$ with certain gold embroidery between the feathers, and from each one hang seven strands of feathers.

a This part is lacking in the Sevillian manuscript. b Around them. cof wheels. d Like. e With a skin. i A fan. ${ }^{2}$ Which finally. h Item: two ducks made. ${ }^{i}$ And they have the quills of the wings and the tails of gold and the claws of the feet and the eyes and the ends of the feet placed, etc. $\quad$ The one white and the other yellow.

\section{A N D MONOGRAPHS}




\begin{tabular}{|c|c|}
\hline 28 & GOLD S M I TH'S A R T \\
\hline & 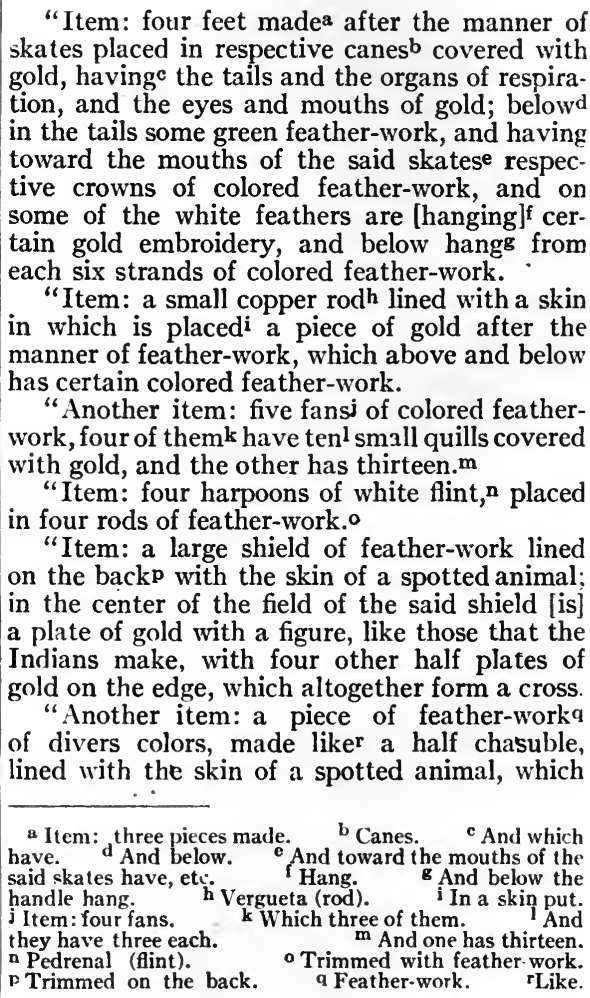 \\
\hline & I N D I N NOTES \\
\hline
\end{tabular}


the lords of these parts whom we have seen up to now, placea hanging from the neck, and over the chest they have thirteen piecesb of gold very well fitted [together].

"Item: a piece of colored feather-work which the lords of this land are wont to put on their heads, ${ }^{c}$ and from it hang two ear-ornamentsd of stone mosaic-work with two bells and two beads of gold, and above a featherwork of wide green feathers, and below hange some white, long hairs.

"Again, four heads of animals: two seem to be wolves, and the other two tigers, $f$ with some spotted skins, and from it hangg metal bells.

"Item: two skins of spotted animals, lined on some mantles of cotton, $\mathrm{h}$ and the skins appear like those of the gato cervali [wildcat?].

"Item: a reddish and grayish skin of another animal, and two other skins that seem like deer.j

"Item: four skins of small deer, of which they make here the small prepared gloves. $k$

"Moreover, two books of those which the Indians have here.

"Moreover: a half-dozen fansl of colored feather-work.

"Moreover: a perfume censer of colored feathers, with certain embroidery on it.m

a Which the lords of these parts, who until now, were put. b And on the breast thirteen pieces. $c$ Like the helmet of one who plays at jousts. $\mathrm{d}$ Ear ornaments. $\mathrm{e}$ From. And the other two tigers. BAnd from them. h Mantles of cotton. $\quad$ Which seems of gato cerval [wildcat?]. i Of another animal which seems to be a lion, and two other deerskins. $\quad \mathrm{k}$ Furthermore: four small tanned deerskins, and furthermore a half dozen [pieces] of stamped leather, which the Indians here make. $\mathrm{m}$ This part is lacking in the Sevillian manuscript.

\section{A ND MONOGRAPHS}




\begin{tabular}{|c|c|}
\hline 30 & GOLDSMITH'S A R T \\
\hline & 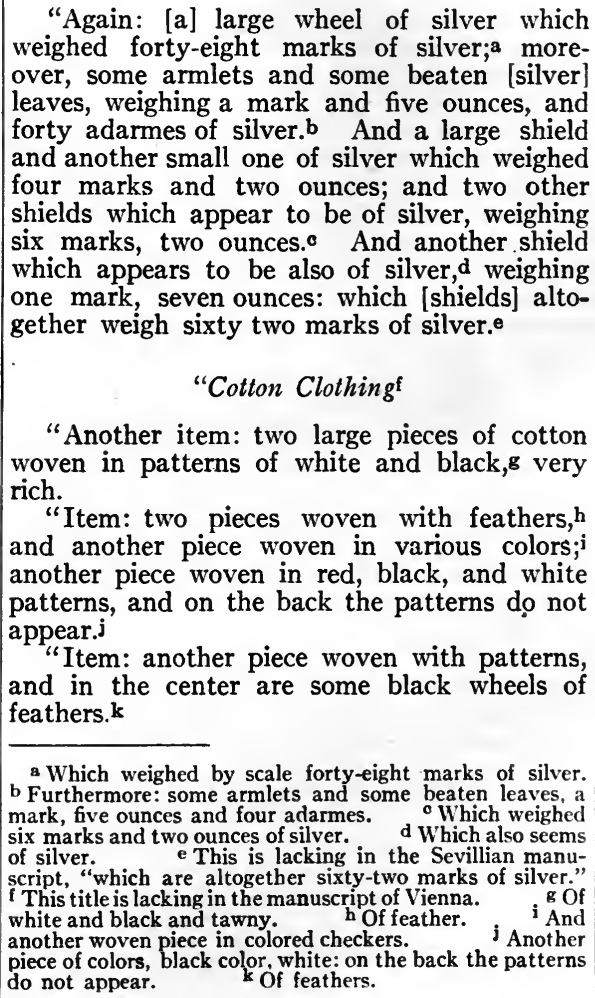 \\
\hline & I NDIAN NOTES \\
\hline
\end{tabular}


"Item: two white cotton cloths with some feather-work woven in.a

"Another cotton cloth with some colored cords attached to it.b

"A loose garment of the men of the land.

"A whitec piece with a great wheel of white feathers in the center.

"Two pieces of grayish guascasad with some wheels of feathers, and two others of tawny guascasa.e

"Six painted pieces, ${ }^{\mathrm{f}}$ another red piece with some wheels, and two other blue painted pieces, and two women's shirts.

"Eleven veils.g

"Six shields, each one having a plate of gold, that covers the shield, and a half miter of gold. $h$ "

"Which things, each one of them, as set forth by these chapters that declare and settle it, we, Alonso Fernandez Puertocarrero and Francisco de Montejo, the said proctors, [certify] it is true that we have received them, and they were delivered to us to carry to their Highnesses, from thou, Fernando Cortés, chief justice for their Highnesses in these parts, and from you, Alonso de Avila and Alonso de Grado, treasurer and overseer of their Highnesses over here. And because it is true, we sign it with our names. Dated, the sixth of July of the year 1519. Puertocarrero. Francisco de Montejo.

a With some woven feather-work. $\quad$ b Another mantle with some little colored pieces stuck on. Another

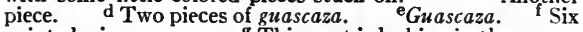
painted pieces. $\quad \mathrm{g}$ This part is lacking in the manuscript of Vienna. ${ }^{\mathrm{h}}$ Six shields, which has each one a plate of gold which covers all the shield.-Item: a half miter of gold.

\section{A ND MONOGRAPHS}

I. x. M. -2 


\begin{tabular}{|l|l|}
\hline 32 & \multicolumn{1}{|c|}{ G O L D S M I T H ' S A R T } \\
\hline "The things above enumerated in the said \\
memorial, with the aforesaid letter and report \\
sent by the Council of Vera Cruz, were received \\
by our Lord, the King, Charles the Fifth, as \\
has been beforesaid, in Valladolid during Holy \\
Week, at the beginning of April, of the year of \\
Our Lord, 1520." [End of the inventory.] \\
"In place of the two preceding paragraphs \\
which are not found in the manuscript of the \\
Manual del Tesorero de la Casa de la Con- \\
tratacion of Seville, there is [there] the following: \\
'All of those said things, as they have come to \\
us, we send to His Majesty with Domingo de \\
Ochandiano, by virtue of a letter which His \\
Majesty commanded us to write about, dated \\
in Molina del Rey, the fifth of December, 1519: \\
and the said Domingo brought a decree of His \\
Majesty, in which he commanded that the \\
above-mentioned things should be delivered \\
to Luis Veret, guardian of the jewels of His \\
Majesty, and the receipt of the said Luis Veret \\
that he had received them, is in the power of \\
the said treasurer.' \\
"Don Juan Bautista Munoz adds: 'It is \\
stated in the same (Manual del Tesorero) \\
that in fulfilment of the said decree, four \\
Indians were richly dressed, two of them \\
caciques, and two Indian girls, who were \\
brought by Montejo and Puertocarrero, and \\
sent to His Majesty in Tordesillas, where His \\
Majesty was [living]. They left Seville, \\
February 7, of the year 1520, and on the trip, \\
and during their stay, and on the return, \\
which was on the twenty-second of March, \\
they spent forty-five days. One of the Indians \\
I N D I A N N O T E S \\
\hline
\end{tabular}




\section{SPANISH LOOT}

did not go to Court, because he was taken sick in Cordoba, and returned to Seville. After coming from Court, one died. The five remained in Seville very well taken care of until March, 1521, the day on which they left on the ship of Ambrosio Sanchez directed to Diego Velasquez in Cuba, that he should do with them that which would be best for the service of His Majesty.'"

\section{Notes by Mora}

"As at the present time many of the terms here are forgotten which are used in this preceding report, it is necessary to give some idea of the things that now correspond to them for greater intelligence. The pujantes or pinjantes that served to adorn the collars and other jewelry were pendants such as are now used in drop ear-rings and necklaces.

"The antiparras or antiparas are described in this manner in the first dictionary of the Spanish language, published by the Academy in 1726 , that gives the origin of the words and authorities in which the meaning is founded: 'certain kind of stockings reaching to the knees or leggings that cover the legs and the feet only, for the front part.' . . . . The patena was a round adornment with some figures sculptured on it, that was worn hanging from the neck.

"The moscador or mosqueador was a kind of feather fan, like those recently used by the women. It was used quite frequently among the ancient Mexicans, and in hardly any paint-

\section{AND MONOGRAPHS}




\begin{tabular}{|c|c|}
\hline 34 & GOLDSM I TH'S ART \\
\hline & $\begin{array}{l}\text { ing of that time, is it not found. They em } \\
\text { ployed in making them the richest feathers } \\
\text { and the handles were adorned with the precious } \\
\text { stones of which they had knowledge. } \\
\text { "The guariques, I have not been able to } \\
\text { discover what thing it was. 15 } \\
\text { "Caparetes were capacetes, a piece of armor } \\
\text { that covered the head. } \\
\text { "The lizas were an imitation of the fish of } \\
\text { that name; placed in sendas cimas, that is. } \\
\text { placed each one in the extremity of a small } \\
\text { rod. In this class of casting with divers metals, } \\
\text { the Mexican silversmiths were very skilful, } \\
\text { for not only dit they know how to take out the } \\
\text { pieces in a single casting, like those here de- } \\
\text { scribed, with the tails, and the sides of the } \\
\text { heads of birds, the eyes and the mouths of } \\
\text { gold, besides altering the scales, some of gold } \\
\text { and others of silver. } \\
\text { "The verjitas were little rods of metal or } \\
\text { other material like a cane or walking-stick, } \\
\text { with some figure or feather-work in the end. } \\
\text { They are frequently seen in the ancient Mexi- } \\
\text { can paintings. } \\
\text { "The prepared gloves are to be understood } \\
\text { as tanned skin. } \\
\text { "The woven pieces of cotton with designs } \\
\text { that do not appear on the reverse, prove the } \\
\text { advancement that they had made, for they } \\
\text { knew how to weave with double woof, for that } \\
\text { is what this artifice consisted of. } \\
\text { "The Indians who were taken to Court, } \\
\text { according to Bernal Diaz, were the four who } \\
\text { were in Tabasco being fattened in 'bird- } \\
\text { cages' of wood, in order to be sacrificed, and }\end{array}$ \\
\hline & I N I A N NOTES \\
\hline
\end{tabular}




\section{SPAN ISH LOOT}

they were the first who were sent as examples of the inhabitants of the land."

The two great discs of gold and silver, likened to cart-wheels in size, which figure as the most imposing of the presents given to Cortés at this time, are described by a number of persons who examined the treasure. These notable pieces were seen and commented on by Bernal Díaz, Andrés de Tápia, Francisco de Aguilar, and a serving man, before they left Mexico. It is strange that they are not mentioned in the letter sent to the Queen and Emperor of Spain by the judiciary and municipal authorities of the newly founded city of Villa Rica de la Vera Cruz, which is dated July 10. They are not specifically referred to in the mention of certain jewels of gold presented to the Captain, "and the others which we obtained afterward of which we make relation to Your Majesties in a memorial which our proctors take with them." This memorial is of course the Inventory printed above. It would be interesting to note what Cortés says about them in the missing First letter.

\section{A ND MONOGRAPHS}




\begin{tabular}{|l|l|}
\hline 36 & \multicolumn{1}{|c|}{ G O L D S M I T H'S A R T } \\
\hline After their receipt in Spain, these wheels, \\
with the rest of the objects, were examined \\
in Seville by Oviedo y Valdes, one Diego \\
Dienz, and an anonymous writer, and in \\
Valladolid by Peter Martyr and Las Casas. \\
Descriptions more or less brief of all these \\
persons have been published, and they all \\
agree in the main. Measurements are at \\
hand to establish the immense size of these \\
discs. The gold wheel, according to Peter \\
Martyr, was 28 palms in circumference; \\
Oviedo and Gomara make it 30. In diam- \\
eter, Oviedo gives it as 91 palms wide, \\
Gomara makes it 10, while the servant \\
gives 7. All the writers say that it was the \\
size of a cart-wheel, except Martyr, who \\
likens it to the size of a millstone. The \\
palm is about $8 \frac{1}{4}$ inches, hence, from the \\
estimates of the diameter, it is safe to say \\
that it measured between five to a little \\
less than seven feet in width and height. \\
The estimates made of the circumference \\
would make it fully six and one-half feet in \\
diameter. The weight of gold is given in \\
the Inventory as 3800 pesos. Peter Mar- \\
tyr writes " 3800 castellanos," while Oviedo \\
I N D I A N N O T E S \\
\hline
\end{tabular}




\section{S P A N I H L OOT}

makes it 4800 pesos, and Las Casas simply thinks that it weighed more than 100 marks, and other writers have different estimates. We are safe in following the $\mathbf{3 8 0 0}$ pesos of the Inventory. Only one estimate is given of its thickness, that of Las Casas, who says that it was of the thickness of a four-real coin, but both Las Casas and Peter Martyr agree in saying that it was massive, hence probably not very flexible.

There can be no doubt that the Mexican calendar was represented on this golden disc, for we have the specific statement that the sun was depicted, by Bernal Díaz, Andrés de Tápia, Francisco de Aguilar, Oviedo, and Las Casas. Bernal Díaz says that it had all kinds of pictures on it; Las Casas writes that certain animals were stamped on it, while Peter Martyr, who is more explicit, describes it as having "in the center the image of a man, a cubit high, resembling a king, seated upon his throne, the figure being draped to the knees: it is like a zemi lan Antillean word for idol], that is to say, it has the features we ascribe to nocturnal goblins." In the Inventory we find the state-

\section{AND MONOGRAPHS}




\section{G OLDSMITH'S ART}

ment that it had on it the figures of monsters.

The silver disc is generally described as being about the same size as the one of gold, one statement being that it was a little finger smaller. All agree that it represented the moon. Clavigero writes that according to what Gomara says, the gold wheel represented the figure of their century, and that of silver the figure of their year. That these extraordinary objects were not preserved is a matter of lasting regret.

The description of the two gold necklaces as given by the early authorities agree in nearly every particular. We have the Inventory, the description of Peter Martyr, and that of Gomara. The first necklace was composed of eight chains or strings, containing 232 red stones,- -so far they are in accord. Peter Martyr and Gomara state that there were also 183 greenstones; the Inventory says 163. Hanging from the necklace were 27 golden bells; the Inventory states that "in the center of them [the line of bells] are four figures of large stones set in gold, and from each one of the two in the

\section{NDIA N NOTES}


center hang simple pendants, and of those at the end, each has four doubled pendants." Martyr says, "The bells are surrounded by four figures set in jewels of wrought gold, and hang from the collar; from each bell hangs a gold pendant." Gomara writes, "Twenty-seven little gold bells and some heads of pearls or rock hang from them [the strings of beads]."

All the writers agree that the second necklace had four chains or strings, 102 red stones, and 172 greenstones. Gomara and the Inventory give 26 gold bells; Martyr does not mention them. The Inventory also states that it contained "ten large stones set in gold from which hang 142 gold pendants." Martyr writes, "ten large stones set in gold from which are suspended 150 wrought pendants." Gomara says, "ten good pearls, not badly set, and for a border 26 little gold bells, and there are other beautiful things besides those mentioned." Thus in the main we have three different accounts which closely agree in their description of these two remarkable collars.

\section{A ND MONOGRAPHS}




\begin{tabular}{|c|l|}
\hline 40 & \multicolumn{1}{|c|}{ G O L D S M I T H'S A R T } \\
\hline $\begin{array}{l}\text { While Cortés was on his famous journey } \\
\text { from the coast to the valley of Mexico, } \\
\text { Montezuma sent to him, in Tlaxcala, valu- } \\
\text { able gold objects which are stated by Bernal } \\
\text { Díaz to have been worth about ten thousand } \\
\text { dollars, and later, while at Cholula, he re- } \\
\text { ceived from the same source a gift of gold } \\
\text { objects worth more than two thousand dol- } \\
\text { lars. On his entry ínto Tenochtitlan, Mon- } \\
\text { tezuma came out on the causeway at the en- } \\
\text { trance of the city to meet Cortés and his } \\
\text { followers, and in exchange for a collar of } \\
\text { pearls and glass beads which Cortés placed } \\
\text { around his neck, he gave to the conqueror } \\
\text { "two collars of prawns, wrapped in a cloth, } \\
\text { which were made of the cores of red shells, } \\
\text { which they esteemed highly, and from each } \\
\text { collar depended eight golden prawns, almost } \\
\text { a span long, executed with much perfec- } \\
\text { tion."'16 } \\
\text { But the treasure already secured was a } \\
\text { mere handful compared with that obtained } \\
\text { by Cortés in Tenochtitlan after the invasion } \\
\text { of the Aztec capital. Reports of the great } \\
\text { wealth hoarded by the Aztecs had been } \\
\text { given the Spaniards by the natives of Tlax- }\end{array}$ \\
\hline \multicolumn{1}{|c|}{ I N D I A N N O T E S } \\
\hline
\end{tabular}


cala. There are very interesting stories as to how the Spaniards came into possession of this treasure. Sahagun, who was not, however, one of the conquerors, says that it was a free-will offering on the part of Montezuma, who conducted the Spaniards to a chamber called Teuhcalco where the wealth inherited from his ancestors was stored, and turned it over to them. ${ }^{17}$

The version of Cervantes de Salazar is that one day Cortés told Montezuma that the King (of Spain) had need of money on account of the great expenses he had incurred in wars. So Montezuma "ordered that some Spaniards should go with certain of his servants to the house of birds, who on entering a great hall saw a great quantity of gold in slabs, small tiles, jewels, and worked pieces." 18

Cortés does not expatiate in his letter about this hoard of gold and other precious objects which had been accumulated and augmented by the different Aztec kings, and handed from monarch to monarch as the property of the people. He mentions in his report to the King of Spain that Mon-

\section{AND MONOGRAPHS}




\begin{tabular}{|c|c|}
\hline 42 & GOLDSMITH'S ART \\
\hline & $\begin{array}{l}\text { tezuma, in refuting the "fabulous stories" } \\
\text { about the vast wealth that he possessed, } \\
\text { such as "houses with walls of gold" and fur- } \\
\text { niture and other things of the same mate- } \\
\text { rial, stated, "It is indeed true that I have } \\
\text { some things of gold, which have been left to } \\
\text { me by my forefathers. All that I possess } \\
\text { you may have whenever you wish." } \\
\text { The most detailed account is that furn- } \\
\text { ished us by Father Diego Duran, "a son of } \\
\text { Mexico," who wrote his invaluable Historia } \\
\text { de las Indias de Nueva España during the } \\
\text { sixteenth century while some of those who } \\
\text { took part in the conquest were still living. } \\
\text { He says that he procured his information } \\
\text { from the mouth of a religious conqueror. } \\
\text { This was Francisco de Aguilar, who is men- } \\
\text { tioned as Alonso de Aguilar by Bernal Diaz, } \\
\text { who states that Friar Aguilar was a good } \\
\text { soldier and a devout man, who later entered } \\
\text { the order of the Dominicans. He was } \\
\text { wealthy, and had a good apportionment of } \\
\text { Indians. When more than eighty years of } \\
\text { age he was persuaded to write an account of } \\
\text { the conquest. This is the fifth account of } \\
\text { the conquest which has come down to us }\end{array}$ \\
\hline & I N I A N NOTES \\
\hline
\end{tabular}




\section{SPANISH LOOT}

from eye-witnesses. It has only recently come to light, the manuscript having been found by Troncoso in the Biblioteca del Escorial in Spain in 1892, and has been published in the Anales del Museo Nacional de Mexico, tomo viI, 1900. It was apparently written about the year 1579, and is entitled "Relatio breue de la Conquista de la Nueva España, por Fr. Francisco de Aguilar de la Orden de Santo Domingo."

Aguilar informed Duran that a search was made with great diligence for the wardrobe and treasure of Montezuma, until one day their solicitude and greed were rewarded by their observing that-

"a very small, low door that was stopped up in a secret chamber, and recently covered with plaster, should not be so without mystery, and it was ordered to be opened, and entering by that narrow and low door, they found a large and spacious room, in the middle of which was a heap of gold, jewels, and precious stones, as high as a man; so high was it, that one was not seen on the other side: which pile. if we wish to know about it according to history, was not a thing acquired by Montezuma, nor a thing that he might be able to profit by, because it was the treasure that all the kings, his forefathers, went on leaving, and which

\section{AND MONOGRAPHS}




\begin{tabular}{|c|c|}
\hline 44 & GOLDSM I'TH'S ART \\
\hline & $\begin{array}{l}\text { the king who came in was not able to profit by: } \\
\text { and so on the death of the king, the same day } \\
\text { that he died, all the treasure that he left of } \\
\text { gold, stones, feathers, and arms, and finally all } \\
\text { his wardrobe, was put in that room, with } \\
\text { much care, as a sacred thing, and of the gods, } \\
\text { soliciting the king who came to reign to acquire } \\
\text { [more]: and so they were there as a treasure of } \\
\text { the city and for the grandeur of it. } \\
\text { "At the same time there was in this room a } \\
\text { great quantity of piles of very rich cotton } \\
\text { cloths and women's finery; there were hanging } \\
\text { on the walls a great number of shields and } \\
\text { arms, and devices of rich workmanship and } \\
\text { colors; there were many piles of vessels of gold, } \\
\text { dishes and porringers made according to their } \\
\text { style, from which the kings ate, especially four } \\
\text { large dishes made like platters, all of gold, very } \\
\text { elaborately worked, as big as a large shield, } \\
\text { and they were so filled with dust that one } \\
\text { understood that many days had passed in } \\
\text { which they had not been in service. There } \\
\text { were many gold chocolate cups, made and } \\
\text { decorated in the same manner of those of the } \\
\text { gourds, used for drinking cacao, some with } \\
\text { feet and others without; there were in the } \\
\text { corners of the room many stones for working } \\
\text { all manner of precious stones; in fine, there was } \\
\text { in this room the greatest riches ever seen, so } \\
\text { that the Spaniards were surprised and mar- } \\
\text { velled [at it], giving notice to the Marquis } \\
\text { and carrying the gold dishes that he might } \\
\text { see the great riches that were there, and running } \\
\text { to see the room; and seeing so much handsome- } \\
\text { ness and beauty, and that they had already }\end{array}$ \\
\hline & INDIAN NOTES \\
\hline
\end{tabular}


that which they desired, he ordered that under penalty of [loss of] life, that no one shculd dare to go near there, and then he sealed up the room as it had been, and placed guards that they should guard it in the name of His Majesty, for there was there the better, and the part of his fifths; and so they placed guards and then closed the room as it had been, so that no one should dare to go there." 19

Other details are given by Bernal Díaz, and we quote what he says about this secret chamber. He writes that, searching for a convenient place to set up an altar in the quarters where they were established-

"two of our soldiers, one of whom was a carpenter, named Alonso Yañes, noticed on one of the walls marks showing that there had been a door there, and that it had been closed up and carefully plastered over and burnished. Now, as there was a rumor and we had heard the story that Montezuma kept the treasure of his father Axayaca in that building, it was suspected that it might be in this chamber which had been closed up and cemented only a few days before. Yañes spoke about it to Juan Velásquez de León and Francisco de Lugo, who were captains and relations of mine, and Alonso Yañes had attached himself to their company as a servant, and those captains told the story to Cortés, and the door was secretly opened. When it was open Cortés and some of his captains went in first, and they

\section{A ND MONOGRAPHS.}




\begin{tabular}{|c|c|}
\hline 46 & GOLDSMITH'S ART \\
\hline & $\begin{array}{l}\text { saw such a number of jewels and slabs and plates } \\
\text { of gold and chalchihuites and other great } \\
\text { riches, that they were quite carried away and } \\
\text { did not know what to say about such wealth. } \\
\text { The news soon spread among all the other } \\
\text { captains and soldiers, and very secretly we } \\
\text { went in to see it. When I saw it, I marveled. } \\
\text { and as at that time I was a youth and had } \\
\text { never seen such riches as those in my life before, } \\
\text { I took it for certain that there could not be } \\
\text { another such store of wealth in the whole } \\
\text { world. It was decided by all our captains and } \\
\text { soldiers that we should not dream of touching } \\
\text { a particle of it, but that the stones should } \\
\text { immediately be put back in the doorway and } \\
\text { it should be sealed up and cemented just as we } \\
\text { found it, and that it should not be spoken } \\
\text { about, lest it should reach Montezuma's ears, } \\
\text { until times should alter." } \\
\text { Andrés de Tápia, one of the most impor- } \\
\text { tant of the captains of Cortés, gives the } \\
\text { credit of the discovery of this secret chamber } \\
\text { to Cortés, for he writes: } \\
\text { "The Marquis, after he had rested a little, } \\
\text { the day that he arrived, exercising the care that } \\
\text { he had for his life and of his company, went } \\
\text { passing around in his chamber, and saw a door } \\
\text { that appeared to have been recently closed with } \\
\text { stone and mortar; and he had it opened, and } \\
\text { entered through it, and found a great number } \\
\text { of chambers, and in some of them considerable } \\
\text { quantity of gold in jewels and idols, and many }\end{array}$ \\
\hline & I N D I A N NOTE S \\
\hline
\end{tabular}


feathers; of these many things were well worth seeing; and having entered with two of his servants, he turned and went out without taking anything whatever."21

That Montezuma kept watch over the movements of the Spaniards, and knew about their discovery of the secret chamber with its hoard of gold, is indicated by Bernal Díaz, who later quotes Montezuma as saying, when about to give up to Cortés this treasure and that which he had collected from different parts of his domain at the "request" of the conqueror, "I know well enough that as soon as you came here you opened the chamber and beheld it all, and that you sealed it up again as it was before."'22

None of the gold specimens of this great loot are now known to exist, and undoubtedly none ultimately escaped the meltingpot. Many estimates as to its intrinsic value have been made, and we will not discuss here the problem of the present-day equivalents of the various terms used by those who drew up the inventories to express the value of the spoil. Prescott makes the amount $\$ 6,300,000{ }^{23}$ Probably the esti-

\section{A N D M N O G R P H S}

I. N. M. -2 


\begin{tabular}{|c|c|}
\hline 48 & GOLDSMITH'S A R T \\
\hline & $\begin{array}{l}\text { mate of the Mexican historian Jose Fer- } \\
\text { nando Ramirez is nearest the truth; he } \\
\text { places the value at about } \$ 3,500,000 .^{24} \text { Let } \\
\text { us turn again to Bernal Diaz for information } \\
\text { concerning it. He writes: } \\
\text { "After some more polite conversation, Mon- } \\
\text { tezuma at once sent his mayordomo to hand } \\
\text { over all this treasure and gold and wealth that } \\
\text { were in the plastered chamber, and in looking it } \\
\text { over and taking off all the embroidery with } \\
\text { which it was set, we were occupied for three } \\
\text { days, and to assist us in undoing it and taking } \\
\text { it to pieces, there came Montezuma's gold- } \\
\text { smiths from the town named Azcapotzalco, and } \\
\text { I say that there was so much, that after it was } \\
\text { taken to pieces there were three heaps of gold, } \\
\text { and they weighed more than six hundred thou- } \\
\text { sand pesos, as I shall tell further on, without the } \\
\text { silver and many other rich things, and not } \\
\text { counting the ingots and slabs of gold, and the } \\
\text { gold in grains from the mines. We began to } \\
\text { melt it down with the help of the natives of } \\
\text { Azcapotzalco, and they made broad bars of it, } \\
\text { each bar measuring three fingers of the hand } \\
\text { across. When it was already melted and made } \\
\text { into bars, they brought another present sepa- } \\
\text { rately, which the grand Montezuma had said } \\
\text { that he would give, and it was a wonderful thing } \\
\text { to behold, for some of the chalchihuites were so } \\
\text { fine that among these caciques they were worth } \\
\text { a vast quantity of gold. - - . Let me say } \\
\text { that all the gold I have spoken about was } \\
\text { marked with an iron stamp, which had been }\end{array}$ \\
\hline & I N D I N NOTES \\
\hline
\end{tabular}


made by order of Cortés and the King's officers, who had been appointed by Cortés with the consent of all of us and in the name of His Majesty until he should give other instructions. At that time these were Gonzalo Mejía, who was treasurer, and Alonso Dávila who was accountant, and the stamp was the royal arms like those on a real and the size of a testoon [a half peso]. The mark was not put on the rich jewels, which it did not seem to us should be taken to pieces. For weighing all these bars of gold and silver, and the jewels which were not taken to pieces, we had neither marked weights nor scales, and it seemed to Cortés and to these same officers of His Majesty's treasury that it would be as well to make some iron weights, some as much as an arroba [twenty-five pounds], others of half an arroba, two pounds, one pound, and half a pound, and of four ounces, and so many ounces, and this not that it would turn out very exact, but within half an ounce more or less in each lot that was weighed.

"After the weight was taken, the officers of the king said that there was of gold, both that which was cast in bars as well as grains from the mines, and in ingots and jewels, more than six hundred thousand pesos, and this was without counting the silver and other jewels which were not yet valued. . . . At that time many of our captains ordered very largegolden chains made by the great Montezuma's goldsmiths . . Cortés, too, ordered many jewels made, and a great service of plate. Some of our soldiers had their hands so full that many ingots of gold, marked and unmarked, and jew-

\section{AND MONOGRAPHS}




\begin{tabular}{|c|c|}
\hline 50 & GOLDSM I T H'S A R T \\
\hline & $\begin{array}{l}\text { e's of a great diversity of patterns, were openly } \\
\text { in circulation. So this was the condition we } \\
\text { were in; but let us stop talking of the gold and } \\
\text { of the bad way it was divided, and worse way } \\
\text { in which it was spent."'25 } \\
\text { We will now quote what the commander, } \\
\text { Cortés, writes about the spoil: } \\
\text { "This decision and offer of the said lords, for } \\
\text { the royal service of Your Majesty having been } \\
\text { completed, I spoke to Montezuma one day, and } \\
\text { told him that Your Highness was in need of } \\
\text { gold, on account of certain works ordered to be } \\
\text { made, and I besought him to send some of his } \\
\text { people, and I would also send some Spaniards, } \\
\text { to the provinces and houses of those lords who } \\
\text { had there submitted themselves, to pray them } \\
\text { to assist Your Majesty with some part of what } \\
\text { they had. Besides Your Highnesses' need, } \\
\text { this would testify that they began to render } \\
\text { service, and Your Highness would the more } \\
\text { esteem their good will toward your service; and } \\
\text { I told him that he should alsogive me from his } \\
\text { treasures, as I wished to send them to Your } \\
\text { Majesty, as I had done with the other things. } \\
\text { He asked me afterward to choose the Spaniards } \\
\text { whom I wished to send, and two by two, and } \\
\text { five by five, he distributed them through many } \\
\text { provinces and cities, whose names I do not re- } \\
\text { member, as the papers have been lost, and also } \\
\text { because they. were many and divers; and more- } \\
\text { over some of them were at eighty and one hun- } \\
\text { dred leagues from the said great city of Temix- } \\
\text { titan. He sent some of his people with them, }\end{array}$ \\
\hline & I N D I A NOTES \\
\hline
\end{tabular}




\section{SPANISH LOOT}

ordering them to go to the lords of those provinces and cities, and tell them that I had commanded each one of them to contribute a certain measure of gold which he gave them. Thus it was done, and all these lords to whom he sent gave very compliantly, as had been asked, not only in valuables, but also in bars and sheets of gold, besides all the jewels of gold, and silver, and the feather-work, and the stones, and the many other things of value which I assigned and allotted to Your Sacred Majesty, amounting to the sum of one hundred thousand ducats and more. These, besides their value, are such, and so marvelous, that for the sake of their novelty and strangeness they have no price, nor is it probable that all the princes ever heard of in the world possess such treasures. Let not what I say appear fabulous to Your Majesty, because, in truth, all the things created on land, as well as in the sea, of which Montezuma had ever heard, were imitated in gold, most naturally, as well as in silver, and in precious stones, and feather-work, with such perfection that they seemed almost real. He gave me a large number of these for Your Highness, besides others he ordered to be made in gold, for which I furnished him the designs, such images, crucifixes, medals, jewelry of small value, and many other things which I made them copy. In the same manner Your Highness obtained, as the one-fifth of the silver which was received, one hundred and odd marks, which I made the natives cast in large and small plates, porringers, cups, and spoons, which they executed as perfectly as we could make them comprehend.

\section{AND MONOGRAPHS}




\begin{tabular}{|c|c|}
\hline 52 & GOLDSMITH'S ART \\
\hline & $\begin{array}{l}\text { "Besides these, Montezuma gave me a large } \\
\text { quantity of stuff, which, considering it was cot- } \\
\text { ton and not silk, was such that there could not } \\
\text { be woven anything similar in the whole world } \\
\text { for texture, colors, and handiwork. Amongst } \\
\text { these, there were many marvelous dresses for } \\
\text { men and women, bed clothing with which that } \\
\text { made of silk could not be compared, and other } \\
\text { stuffs, such as tapestry, suitable for drawing- } \\
\text { rooms and churches. There were also blankets } \\
\text { and rugs, for beds, both made of feather-work } \\
\text { and of cotton in divers colors, also very marvel- } \\
\text { ous, and many other things so curious and nu- } \\
\text { merous I do not know how to specify them to } \\
\text { Your Majesty. He also gave me a dozen cer- } \\
\text { batanas (blow guns) with which he shoots, and } \\
\text { of their perfection I likewise know not what to } \\
\text { say to Your Highness; for they were decorated } \\
\text { with very excellent paintings of perfect hues, in } \\
\text { which there were figures of many different kinds } \\
\text { of birds, animals, trees, flowers, and divers other } \\
\text { objects, and the mouth-pieces and extremities } \\
\text { were bordered with gold, a span deep, as was } \\
\text { also the middle, all beautifully worked. He } \\
\text { gave me a pouch of gold network for the ball, } \\
\text { which he told me he would also give me of gold. } \\
\text { He gave me also some turquoises of [set in] gold, } \\
\text { and many other things, whose number is almost } \\
\text { infinite." } \\
\text { But the Spaniards were not to receive the } \\
\text { full benefit of all this plunder. On the con- } \\
\text { trary, its possession was to be the cause of } \\
\text { the loss of many lives. After the uprising }\end{array}$ \\
\hline & I N D I N NOTES \\
\hline
\end{tabular}




\section{SPANISH LOOT}

of the Indians subsequent to the imprisonment and death of Montezuma, Cortés saw that he could no longer retain in safety to himself and followers the capital city. Again let Bernal Díaz tell the story of the preparations made for the retreat:

"In order to bring out the gold and divide it up and carry it, Cortés ordered his steward, name Cristóbal de Guzman, and other soldiers who were his servants, to bring out all the gold and jewels and silver, and he gave them many Tlaxcalan Indians for the purpose, and they placed it in the Hall. Then Cortés told the King's officers named Alonso Dávila and Gonzalo Mejía, to take charge of the gold belonging to the His Majesty, and he gave them seven wounded and lame horses and one mare, and many friendly Tlaxcalans, more than eighty in number, and they loaded them with parcels of it, as many as they could carry, for it was put up into very broad ingots, as I have already said in the chapter that treats of it, and much gold still remained in the Hall piled up in heaps. Then Cortés called his secretary and the others who were King's notaries, and said, 'Bear witness for me that I can do no more with this gold. We have here in this apartment and Hall over seven hundred thousand pesos in gold, and, as you have seen, it cannot be weighed nor placed in safety. I now give it up to any of the soldiers who care to take it, otherwise it will be lost among these dogs [of Mexicans].' When

\section{A N D MONOGRAPHS}




\begin{tabular}{|c|c|}
\hline 54 & GOLDSMITH'S ART \\
\hline & $\begin{array}{l}\text { they heard this, many of the soldiers of Narvaez } \\
\text { and some of our people loaded themselves with } \\
\text { it." } \\
\text { The great fight between the Spaniards } \\
\text { and the Mexicans took place at the bridges } \\
\text { placed by the Spaniards over the canals, } \\
\text { and Bernal Díaz says that "the passage or } \\
\text { water opening was soon filled up with dead } \\
\text { horses, Indian men and women, servants, } \\
\text { baggage, and boxes." His estimate of the } \\
\text { number of men lost in five days' fighting is } \\
\text { eight hundred and sixty soldiers, and more } \\
\text { than one thousand 'Tlaxcalan Indians. He } \\
\text { remarks that "if many more of the followers } \\
\text { of Narvaez than those of Cortés died at the } \\
\text { bridges, it was because they went forth } \\
\text { laden with gold, and owing to its weight } \\
\text { they could neither escape nor swim." } \\
\text { Duran makes the statement that Cortés } \\
\text { lost "seven hundred men, whom the Indi- } \\
\text { ans hacked to pieces without any mercy, } \\
\text { those canals remaining filled with dead men, } \\
\text { horses, and Indian men and women without } \\
\text { number, and filled with the gold and jewels } \\
\text { which these badly risked [people] had car- } \\
\text { ried, and of mantles, feathers, and all kind }\end{array}$ \\
\hline & INDIAN NOTES \\
\hline
\end{tabular}




\section{SPANISH LOOT}

of riches." ${ }^{\text {"28 }}$ Cervantes de Salazar, in commenting on the losses suffered by the Spaniards on this night, June 13,1520, and still known as the "Noche Triste," says that there were many estimates as to the number of lives lost, but his estimate, which he says is the nearest the truth, is six hundred Spaniards, four thousand Indian allies, all their prisoners, and forty-six horses. ${ }^{29}$

We are in ignorance as to how much of the great treasure was lost at this time. Cortés says that "all the gold and jewels and many other things which we carried, and all the artillery, were lost;" but Bernal Díaz says, "The horses with the gold and the Tlaxcalans got out in safety." Cortés speaks of much treasure belonging not only to the King but to himself that had to be abandoned in the city, and also states that some of the loot left behind which certain of his followers later tried to take to Vera Cruz, was captured on the road.

We are fortunate in having had published during recent years several of the lists drawn up and certified to, which accompanied this and other treasure sent by Cortés

\section{A N D MONOGRAPHS}




\begin{tabular}{|c|c|}
\hline 56 & GOLDSMITH'S A RT \\
\hline & $\begin{array}{l}\text { to Spain during the years from } 1520 \text { to } \\
\text { 1526. We herewith append translations of } \\
\text { eight of these inventories which have come } \\
\text { to light in the archives of Spain. }{ }^{30} \text { They are } \\
\text { interesting as giving some slight description } \\
\text { and as conveying some information regard- } \\
\text { ing the character of the very few gold jewels } \\
\text { and other precious objects which were not } \\
\text { torn to pieces by the Spaniards in order to } \\
\text { get out the gold for melting. } \\
\text { INVENTORIES } \\
\text { REPORT of THE FEATHER-work AND JEwELS } \\
\text { SENT To SPAIN TO BE DiSTRIBUTED TO THE } \\
\text { FOLLOwnG CHURCHES AND MoNASTERIEs AND } \\
\text { SPECIAL PERSONS. (Without date.) } \\
\text { (Archives of the Indies, Patronato, Cabinet 1, } \\
\text { Box 1.) } \\
\text { First Box } \\
\text { For Our Lady of Guadalupe } \\
\text { Item: a shield, with a field of blue, with a } \\
\text { First, a lpiece of] feather-work like a cape, the } \\
\text { center green and the border of long green plumes, } \\
\text { the neck part worked with gold and blue feath- } \\
\text { ers, lined with a tiger-skin. } \\
\text { Item: a cosete (corselete, corselet?) of blue } \\
\text { feathers and gold, open at the breast, like those } \\
\text { used in sacrificial ceremonies, as customary } \\
\text { here, with the girdle of green feathers. } \\
\text { man the center wrought of gold. }\end{array}$ \\
\hline & I N I A N NOTES \\
\hline
\end{tabular}




\section{N V E N T O R I E S}

For the Monasterio de las Cuevas de Sevilla

A [piece] of feather-work of red feathers, the center and the neck part blue and red, with some gold, and in the field are strewn some ears of corn, with the border of green feathers and gold.

Item: a red shield with a blue field, and in the middle a head of gold from which emanates shining lights.

For Our Lady of the Antigua of the City of Sevilla

A [piece of] feather-work like the half of a chasuble, the center and the border green, and the collar green with some colored figures in it.

Item: a vestment for the body and legs of yellow feathers with the girdle green and in the center of the said vestment some red spots, and strewn all over with embroidery of gold.

Item: a shield, the field blue, with a man figured in the center, of gold and feathers, and the border yellow.

Item: also, a small hood, green and yellow, [shaped] like the little hood of a gold cape.

For the Chapel of Sant Elifonso of the Principal Church of Toledo

A [piece of] feather-work, fashioned like onehalf of a chasuble, the field green, the border yellow, and with the head-piece of green feathers and gold.

Item: a shield, blue and green, and in the center an arrow of gold and feathers.

Item: a fan, green and red, with some green and yellow flowers, and some gold embroidery.

\section{A ND MONOGRAPHS}




\begin{tabular}{|c|c|}
\hline 58 & GOLDSM I'TH'S A R T \\
\hline 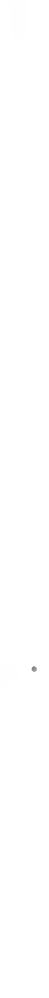 & $\begin{array}{l}\text { Item: another fan, brown and round, [made] } \\
\text { of turkey-feathers, with some gold. } \\
\text { Item: another small cape like the hood of a } \\
\text { choir cape, the field and border blue, [with] } \\
\text { some buttons worked from gold at the ends } \\
\text { around it. } \\
\text { For the Crucificio of Burgos } \\
\text { A [piece of] feather-work of long green feath- } \\
\text { ers, the center and border of red and green } \\
\text { feathers. } \\
\text { Item: a shield, the field blue, with a man fig- } \\
\text { ured in the center of plumes of gold. } \\
\text { Item: a fan of green and orange feathers, } \\
\text { with some embroidery. } \\
\text { Item: a duck made of green feathers and } \\
\text { some gold. } \\
\text { For Santo Tomás de Avila } \\
\text { A feather-piece made like a half chasuble, } \\
\text { the field green, of long feathers, and the border } \\
\text { red, with some small blue buttons at the end. } \\
\text { Item: a shield, the field blue, and [the image } \\
\text { of] a man [made] of feathers and gold figured } \\
\text { on it. } \\
\text { Item: a fan of green feathers, with ten small } \\
\text { gold quills. } \\
\text { Item: a cord for the hair, which consists of } \\
\text { two small pieces of feather-work of green and } \\
\text { red feathers tied together, with some small } \\
\text { gold quills. } \\
\text { For San Francisco de Cibdad de Real } \\
\text { Ale, one half of red feathers, the other half of }\end{array}$ \\
\hline & I N D A N NOTES \\
\hline
\end{tabular}




\section{N V E N T O R I E S}

long green feathers, and the border of red feathers, with some colored bands on the neck part, and some moons of gold.

Item: a shield, the field green, with a serpent of gold in the center.

Item: a cord, that is to say, two small pieces of plumage of green feathers tied together, with some fore-feet of the tiger, with claws of gold.

For the Monastery of the Order of San Gerónimo

A feather-piece like a half chasuble, the field red and the border green, the neck part of gold and blue, with certain gold embroidery.

Item: a shield, the field blue, with a serpent of gold and red feathers in the middle.

Item: two red birds with green tails, of feathers.

For the Monastery of San Francisco de la Villa de Medellin

A feather-piece made like a half chasuble, the field red and the border of long green feathers, the neck part made of gold and green feathers.

Item: an eagle with the tail green, with certain gold-work on it, and a gold mirror in the middle.

Item: a fan of green feathers with gold embroidery, and a cuco (caterpillar) of gold in the center.

Item: two birds of green feathers with beaks of gold.

Item: a corselet, a man's vestment of red feathers, the girdle of green feathers, with embroidery of gold strewn all over it.

\section{A N D MONOGRA P H S}




\begin{tabular}{|c|c|}
\hline 60 & GOLDSMITH'S ART \\
\hline & $\begin{array}{l}\text { Item: a green branch. } \\
\text { Item: a shield with the head of a monster } \\
\text { in the middle, of gold. } \\
\text { Item: another shield with the field blue, } \\
\text { with some bars of gold, and some [ornaments] } \\
\text { like gold snail-shells close to it. } \\
\text { Item: three cords of green feathers, that is, } \\
\text { six small pieces of feather-work tied together in } \\
\text { pairs, which are mounted on the feet of golden } \\
\text { eagles. } \\
\text { Item: a fan of tortoise shell. } \\
\text { For Santa Clara de Tordesillas } \\
\text { Two feather-pieces of feathers and gold, one } \\
\text { with certain long green feathers. } \\
\text { Item: a shield, the field blue, with a serpent } \\
\text { of gold and red feathers in the center. } \\
\text { For San Salvador de Oviedo } \\
\text { A piece of feather-work of long green feathers, } \\
\text { with the border red, and the neck part of green } \\
\text { feathers and gold. } \\
\text { Item: a shield, the field green, with a mon- } \\
\text { ster, the body [of which is] of gold, and the face } \\
\text { has some loops, and around the head are some } \\
\text { scallops of gold. } \\
\text { For Senor Santiago de Galicia } \\
\text { A large feather-piece, green and round, with } \\
\text { a large wheel of gold in the center. } \\
\text { Item: a shield having in the middle an arm } \\
\text { with two monsters of gold, the arm being of } \\
\text { feathers and gold embroidery. } \\
\text { Item: another shield, the field blue, with }\end{array}$ \\
\hline & I NDIAN NOTES \\
\hline
\end{tabular}


three plumes of gold, and at the top some flowers of gold plumes.

Item: a crest (head-piece) of green and red feathers which are tied together.

Item: another larger feather-piece, green and red, and [with] two plates of gold on both sides.

Item: another feather-piece, like a hood, the field green, with the border of some loops of gold.

For Our Lady of the Portal de Toro

A feather-piece like a mozetta made of some bands of different colors, and gold embroidery, and the neck part of gold and blue.

Item: a shield, the field red, and in the center a monster of gold and feathers.

Item: a cord of two small green featherpieces, tied with gold.

\section{For the Lord Bishop of Burgos}

A cape like a mozetta, the field blue, of thick gold embroidery, and the collar elaborately trimmed with colored feathers, and the border white.

Item: one [cape] something like a green hood: this collar is elaborately trimmed with designs and colors of feathers and gold, and on the border are monsters embroidered in feathers.

Item: four shields, one of a monster of many colors and gold, with the field blue; the other, the field green worked in blue and gold, with a ruby in the center; the other with the field blue,

\section{A N D MONOGRAPHS}




\section{GOLDSMITH'S ART}

and two wheels of gold in the center, and a monster in one of the wheels; the other, the field blue, with four snail-shells of gold on it, and two gold bands.

Item: a parrot worked in feathers lying (or resting) on some herbs (or twigs?), with a gold beak.

Item: a parrot worked in feathers, perched (or sitting) on grass.

Item: a large cicada of feathers, that is madc after the manner of betalcs (veined?).

Item: a feather-piece of a cimera (crest of a helmet or coat of arms), with some long green feathers, and some gold quills that appear like a sprig or vinc.

Item: something like a staff (crosier?) of stone mosaic-work of many colors, for him (the Bishop).

\section{For the Lord Cardinal of Tortosa}

Item: two shields, one, the field yellow, with a large cicada of gold and blue feathers in the middle; the other, the field blue and green, with a golden sun and other fancy designs on it.

For the Lord Admiral of Castilla

Item: thrce shiclds, one the field green with some serpents of gold and blue in the center; the other, the field green with the head of an owl in the middle; the other, the field red with some fancy work of gold.

For the Lord Constable of Castilla

Item: three shields, one, with half of the field blue, with some moons and bars of gold,

\section{N D I A N NOTES}


the other half red, without feathers, and with two half-wheels of gold; the other two, with some serpents of gold and fields of blue feathers.

For the Lord Bishop of Palencia, Don Pedro Ruiz de la Mota

Item: three shields, one [with] the field red, with a monster of gold and feathers; another, the field green, with a serpent of gold and blue in the center; the other, the field blue, with a red butterfly of gold.

\section{For Don García de Padilla}

Item: three shields, one, the field ycllow and red, with four heads of monsters of gold and feathers, and a green band in the center; another, the field green, with a serpent of gold ancl blue in the middle; the other, the field red, with a large bee of gold and feathers in the center.

\section{For the Licentiate Zapata}

Item: two shields, one, the field blue, with a monster of gold and feathers in the center; the other, the field green, with a serpent of gold and blue in the center.

\section{For the Secretary Cobos}

Item: three shields, one, the field blue, with a monster of gold and feathers in the center; another, the field green, with a serpent of gold; the other, the field white, with a loop (or bow) and feathers, and some scallops of gold.

\section{A N D MONOGRAPHS}




\begin{tabular}{|c|c|}
\hline 64 & GOLDSMITH'S A R T \\
\hline$\cdot$ & $\begin{array}{l}\text { For the Lord Knight Hernando de Vega } \\
\text { Item: two shields, one, the field blue, and an } \\
\text { eagle of feathers in the center, with the feet and } \\
\text { beak of gold, and a snake in the golden beak; } \\
\text { the other, the field blue, and a serpent of gold } \\
\text { and red feathers. } \\
\text { For the Licentiate Polanco } \\
\text { Item: two [three] shields, one, the field blue } \\
\text { and a serpent in the center, and the center is } \\
\text { [made] of red feathers; another, the field green, } \\
\text { and another serpent of gold and blue; the other, } \\
\text { the field blue, and a serpent of red feathers and } \\
\text { gold in the center. } \\
\text { [See Note 110, page } 224 \text {.] } \\
\text { For the Secretary Juan de Sámano } \\
\text { Item: a shield, the field blue, and a red ser- } \\
\text { pent of gold and blue, for the Secretary Juan de } \\
\text { Samano. } \\
\text { For Pedro Martin } \\
\text { Item: a shield, the field blue, and a red ser- } \\
\text { pent of gold in the center. } \\
\text { [with] four snail-shells of gold in the middle, } \\
\text { and two bands of gold in the center; another, } \\
\text { Item: a shield, the field red, and in the cen- } \\
\text { ter a gold wheel with a serpent's mouth above. } \\
\text { For the Licentiate Santiago }\end{array}$ \\
\hline & I NDIAN NOTES \\
\hline
\end{tabular}




\section{N V E N T O R I E S}

the field blue, and the leg of a golden eagle in the middle; the other, the field red, and a serpent of gold and blue; this [latter] is for Don Diego Pacheco, his son.

\section{For the Lord Duke of Alba}

Item: two shields, one, the field green and red, with three birds worked in gold and feathers; the other, the field red, and a serpent of gold and feathers; the other, the field red, and a serpent of gold and blue in the center.

\section{For Señor Antonio de Fonseca}

Item: two shields, one, the field red, and a head of a monster of gold and feathers in the center; the other, the field red, with a serpent of gold and blue in the center.

\section{For Doctor Carbajal}

Two shields, one, the field green, with a monster of blue and of gold; the other, the field blue, and a red and gold serpent in the center.

\section{For Mingoval, Master of the Horse}

Two shields, one, the field red, with a serpent of gold and blue; the other, the field blue, with some branches of gold like a loop (or bow).

For the Chief Steward Mosiu de Urré

Two shields, one, the field blue, with a serpent of gold and red feathers in the center; the other, the field yellow, with a cicada of gold and red feathers.

\section{A ND MONOGRAPHS}




\begin{tabular}{|c|c|}
\hline 66 & GOLDSMITH'S ART \\
\hline • & $\begin{array}{l}\text { For the Governor Baeza } \\
\text { Two shields, one, the field blue, with a ser- } \\
\text { pent of gold and red feathers in the middle; the } \\
\text { other, the field red, and a large cicada of gold } \\
\text { and blue in the center. } \\
\text { For the Count de Medellin } \\
\text { Two shields, one square, the field blue, with } \\
\text { a red band in the middle, and a loop (or bow) } \\
\text { of gold; the other, the field red, with a serpent } \\
\text { of gold and blue in the center, and also two } \\
\text { feather birds, the body red and the wings green; } \\
\text { and also two round feather fans. } \\
\text { For Don Juan Puerto-Carrero, grandson of the } \\
\text { Count de Medellin } \\
\text { Two shields, one, the field yellow, with a } \\
\text { wheel of gold and feathers in the middle; the } \\
\text { other, the field without feathers, and some } \\
\text { bands of blue feathers and some stripes of gold; } \\
\text { furthermore, a little hood of colors of snakes. } \\
\text { Fernando Cortés. } \\
\text { Note: This document does not give the date } \\
\text { in which it was made, but it must have been in } \\
\text { the first years of the conquest of New Spain, } \\
\text { from what appears in the report. } \\
\text { REPokr of THE OBJEcrs of Goond THAT ARE } \\
\text { PACKED IN A Box FOR HIs MAJESTY wHICH } \\
\text { ARE SENT IN CARE OF DIEGo DE SoTO. (With- } \\
\text { out date.) } \\
\text { (Archives of the Indies, Patronato, Shelf 1, Box 1.) } \\
\text { A tiro (cast ?) called Fenix, of silver weighing }\end{array}$ \\
\hline & I N D A N NOTES \\
\hline
\end{tabular}




\begin{tabular}{|l|l|}
\hline I N V E N T O R I E S & 67 \\
\hline twenty-two and one-half quintal when it was \\
placed in the melting pot. \\
A mirror with two figures. \\
A mirror with a figure of guaxteca [?]. \\
A guaxteca[?] mirror with a crystal in the \\
narices (nostrils). \\
A round mirror like a sun. \\
A large round mirror. \\
A mirror with the head of a lion. \\
A mirror with the figure of an owl, with some \\
chalchihuites. \\
A mirror with a case of knife stone (obsidian \\
or flint). \\
Two carnicles[?] with their pendants, and a \\
tree on them with a little bird. \\
A necklace with ten bollones (large nails \\
with large heads). \\
A similar necklace of twenty-two pieces, with \\
their pendants. \\
Another necklace with some round hawk- \\
bells. \\
A necklace with eighteen large pieces, of the \\
form of the head of an eagle, with their pendants. \\
A small necklace of doubled pieces with their \\
pendants. \\
A necklace of turtles, forty-eight pieces with \\
their pendants. \\
A necklace with eight beads and ten weights \\
like turtles, with a man. \\
A necklace of eight pieces with their pendants. \\
A necklace like turtle-shells of fifteen pieces \\
with their pendants. \\
\hline A N D M O N O G R A P H S \\
\hline
\end{tabular}


A necklace of snail-shells of fifteen pieces with pendants.

A necklace of snail-shells of forty pieces without pendants.

A necklace with nine pieces like the heads of men, with their pendants. pieces.

A necklace of small snail-shells of eighteen

A necklace with nine round beads and eight eye-teeth of lizards.

A necklace with twenty-seven large cicadas with their pendants.

A necklace of snail-shells of twenty-nine pieces without pendants.

A large necklace like a gorget of gold.

A large disc of gold with a monster of the figure of a man.

Another disc of gold of the same kind.

Two gold flutes.

Three rosettes of gold like artichokes.

Another rosette of gold with six leaves (petals) and six gold beads.

A rosette of gold also with six leaves, three of silver, the other three of gold.

A piece of chalchihuite like a bell set in gold with a small bird and a large cicada.

A flower of chalchihuite set in gold and on it a little tree.

A turtle of gold set in a chalchihuite.

A head of gold with the face of chalchihuite, and a necklace of small snail-shells of silver.

Three pieces of the same kind set in chalchihuites, and with other large chalchihuites with settings of gold at the end.

\section{NDIA N NOTES}




\section{N V E N T O R I E S}

A large piece like a pyx with a large chalchihuite in the middle.

A shield of gold with a banneret and three rods fastened on the back with their flints.

A head of chalchihuite with eleven strings of chalchihuites: at the end of each one a snailshell of gold.

A head of gold, with the face of greenstone with its ear ornaments, and very small snail-shells.

$A$ head of green and white stone, with a small tube of gold through the nose.

A head of an animal set in gold, with many pendants.

A head of greenstone set in gold, with ears of snakes, and some very small snail-shells at the end.

A stone head which looks like porfirio (porphyry), set in gold with four small emeralds.

A green head set in gold, with its hair tied by a cord, and small gold ears.

A head, also looking like porfirio, set in gold with a garland of gold, and having on the forehead a snake's head.

A head of greenstone set in gold, which has in the hair a gold twist.

A head of chalchihuite, that looks like porfirio, wide, and having for ear ornaments two little bells with two butterflies, and some little hawk-bells at the end.

A similar piece with different ear ornaments.

A death's head of gold.

A head of greenstone set in gold, with plumes of gold hanging [down].

A head, one half of gold, and one half of greenstone, with the mouth of a snake.

\section{A ND MONOGRAPHS}




\begin{tabular}{|c|c|}
\hline 70 & GOL D S M I TH'S A R T \\
\hline & $\begin{array}{l}\text { A head of gold and greenstone. } \\
\text { A head of greenstone set in gold, with mouth } \\
\text { and chin of gold. } \\
\text { A head of greenstone set in gold, with gold } \\
\text { flowers at the end of the pendants; sixteen heads } \\
\text { of monsters differing one from the other, of gold. } \\
\text { 'Two monsters of gold made [in the shape of] } \\
\text { ducks. } \\
\text { A cerni [cemi, zemi] of gold with a stone in } \\
\text { the belly and four pendants. } \\
\text { An eagle of gold with four hawk-bells in the } \\
\text { tail. } \\
\text { Two small discs with their monsters. } \\
\text { A disc with a monster and eight pendants. } \\
\text { A large stone set in gold, and a flower of } \\
\text { silver and gold. } \\
\text { Fourteen medals with pendants and without } \\
\text { them, all with their greenstones. } \\
\text { A purple shell with a green chalchihuite in } \\
\text { the center set in gold. } \\
\text { A piece of gold with five hearts and a round } \\
\text { greenstone, and another long one set in gold. } \\
\text { A stone flower set in gold with a border of gold. } \\
\text { A gold flower with six leaves and a green- } \\
\text { stone in the middle. } \\
\text { A greenstone set in gold and on the bottom } \\
\text { a turquoise. } \\
\text { Three little flowers of gold and greenstones, } \\
\text { one with two beads and the other with a cross. } \\
\text { A large flower of three leaves having inside } \\
\text { five other leaves that move. } \\
\text { Five butterfies, three of gold and stone, and } \\
\text { two of red and green shell. } \\
\text { Two alcarrazas (porous jars generally with } \\
\text { two handles) of gold, with their pendants. }\end{array}$ \\
\hline & I N I A N NOTES \\
\hline
\end{tabular}


A head of averramia of gold, with its pendants.

Seventeen pieces of medals with their greenstones, some with pendants, others without.

Sixteen red shells set in gold.

Two white snail-shells with greenstones tied with gold thread.

Three flowers of land snail-shells set in gold.

Eight spindles with their whorls and a spinner which carries the spindle, all of gold.

Nine gold spoons.

A spoon of silver and gold.

A little duck of gold coming out of a stone.

A face of gold with the features of stone mosaic.

Three gold tigers.

Sixty-nine gold beads and six chalchihuites and a tiger of gold, all on a bead-string.

A rosary with seventy-seven beads and a rosette of gold.

Eighteen leathers of eagle-claws of silver and gold; there are in all sixty eagle-claws.

Three armlets of points made of gold.

Six bracelets for the arms, made of gold.

Fifteen strands in a necklace of beads, green and of gold, and hawk-bells.

An armlet of claws and fingers of gold.

A face of tiger-skin with two ear ornaments of gold and stone mosaic.

A necklace for a grayhound, of turquoise. the lips.

Six lip ornaments of gold which they put in

A lip ornament of amber adorned with gold.

A lip ornament of gold of the same workmanship as that of amber.

\section{A N D MONOGRAPHS}




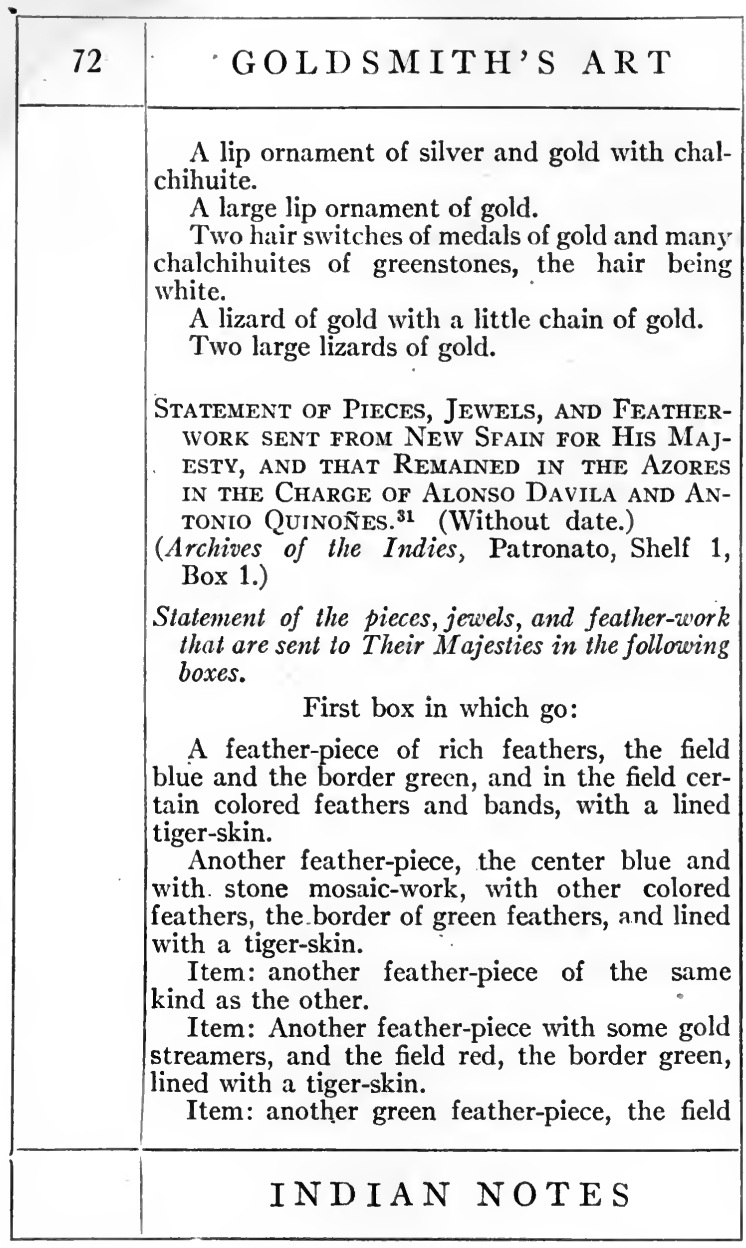


red and some bands of divers colors and the border green.

Item: another feather-piece, the field green of minute feathers, and the border green and the neck part adorned with much fancy work of gold and feathers.

Item: another feather-piece of the same kind, except that the feathers of the field are longer.

Item: $t$ wo feather-pieces like mosaics, one, the field green worked with gold; and the other, the field blue, also worked in the same manner with gold, and the border of both of long green feathers with much fancy work on them.

Item: two green feather-pieces, cimeras (helmets) with gold embroidery-work in the center, and along the neck part, among which fancy work there are blue feathers.

Item: two others of the same kind as those above.

Item: two others of the same kind.

Item: another of the same kind.

Item: another mosetta embroidered with feathers of various colors and gold embroidery.

Item: another helmet (cimera) of feathers, green, red, blue, and flesh-colored, worked with gold embroidery, with a medal of gold on the front, with certain hair placed on it.

Item: a branch made of feathers, with some clusters or streamers extending from it.

Item: a poma (a box or container in the shape of an apple, for perfumes or incense) of green feathers with gold embroidery.

Item: another poma of colored feathers without embroidery.

\section{A N D MONOGRAPHS}




\begin{tabular}{|c|c|}
\hline 74 & GOL D S M I TH'S A R T \\
\hline & $\begin{array}{l}\text { Item: a cornstalk with its ears. } \\
\text { Item: a thistle made of green feathers. } \\
\text { Item: another leaf of thistle. } \\
\text { Item: a plumage with its socket (base). } \\
\text { Item: an eagle with the beak and wings of } \\
\text { gold and feathers. } \\
\text { Item: a small crest (headpiece) with a wheel } \\
\text { like a star with gold embroidery. } \\
\text { Item: a cord for the hair, which are two } \\
\text { small feather-pieces with two birds, with gold } \\
\text { embroidery. } \\
\text { Item: a small hood, the field red and the bor- } \\
\text { der blue. } \\
\text { Item: a poma, green, blue, and other colors, } \\
\text { with gold embroidery. } \\
\text { Item: another feather-piece of large size, } \\
\text { like a cape, with the field green, the border of } \\
\text { many-colored feathers with its buttons around } \\
\text { it, and lined with a tiger-skin. } \\
\text { Item: a helmet with the beak of an eagle, in } \\
\text { gold, worked with diverse fancy-work, with gold } \\
\text { embroidery, the field of blue feathers and the } \\
\text { rest of long green feathers. } \\
\text { Item: a mozetta, the field green, worked } \\
\text { with gold, and long green feathers on the border. } \\
\text { Item: also two branches of green feathers } \\
\text { Seventy-two shields, worked in green feath- } \\
\text { ers as well as other colors, with many monsters } \\
\text { and divers other things, made of gold in a } \\
\text { strange manner. } \\
\text { Item: also a helmet of red feathers with gold } \\
\text { embroidery, at the top of which is a greeil } \\
\text { feather. } \\
\text { Item: }\end{array}$ \\
\hline & I N I A N NOTES \\
\hline
\end{tabular}


and gold with some little hawk-bells, and above the top of them is a feather and gold.

Item: also another small plumage with base (or socket) of feathers at the end.

Small square box in which goes:

A shield with blue stone mosaic with its rim of gold.

Item: there also goes with the said shield, a corselet of gold armor, like a confas[?], with teats like a woman, with the nipples blue, and the skirt with blue bands.

Item: another corselet of the same kind, without teats, but showing on the breasts sacrificial markings, such as in sacrifices performed here.

Item: another of the same kind, with hands and sacrificial marks on the breasts.

Item: another small corselet, lacking the skirt, likewise all of gold.

Another small box in which goes:

A shield of stone mosaic-work, with a rim of blue and red feathers.

Item: there also goes in the said box, a corselet of the same kind as those in the above box.

Item: another corselet of the same kind, with a green band on the skirt.

Another small box in which goes:

A shield of stone mosaic-work, the casco (crown) of feathers and the clasps of gold, and on the rim some long green feathers.

\section{A ND MONOGRAPHS}




\begin{tabular}{|c|c|}
\hline 76 & GOLD SM I TH'S A R T \\
\hline - & $\begin{array}{l}\text { Another round box lined with deerskin. } \\
\text { A shield of stone mosaic-work and confas } \\
\text { (shells?), with some pendants on the rim, of } \\
\text { large and small gold bells. } \\
\text { Another small square box. } \\
\text { Six shields of gold with their clasps and all, } \\
\text { and two other shields of gold and silver that } \\
\text { make altogether eight. } \\
\text { Another small square box in which go: } \\
\text { Eighteen shields of gilded silver, that make } \\
\text { altogether twenty. } \\
\text { Item: two more masks and an arrow of gold. } \\
\text { REPORT of THE THINGS CARRIED BY DIEGO } \\
\text { DEL SoTo FROM THE GovERNOR IN ADDITION } \\
\text { TO wHAT HE CARRIES LISTED IN A NoTE- } \\
\text { BOoK of CERTAIN SHEETS OF PAPER FOR } \\
\text { His MAJESTY. (Without date.) } \\
\text { (Archives of the Indies, Patronato, Shelf } 1 \text {, } \\
\text { Box 1.) } \\
\text { There go in a large wide box made in the } \\
\text { Indies, the following: } \\
\text { A large shield with some moons of stone } \\
\text { mosaic-work and with much gold. } \\
\text { Another shield with the image of a man in } \\
\text { gold, whose breasts have been cut open for sac- } \\
\text { rifice, a gush of blood emanating from these } \\
\text { sacrificial cuts; some scallop-shells of silver. } \\
\text { Another shield of gold and feathers repre- } \\
\text { senting the same thing as the one above. }\end{array}$ \\
\hline & I NDIAN NOTES \\
\hline
\end{tabular}




\section{N V E N T O R I E S}

Another shield of blue feathers with a serpent of gold in the center.

Another shield of red feathers, with a cerco (rim or border) of imagery of gold, and in the center a disc of gold, also of imagery.

Another shield of feathers, red and green, with some butterflies and gold embroidery.

Another shield with a blue and green field, with some stripes, and in the center an eagle of feathers with the body of gold [marked] like the shell of a turtle.

Another shield with a blue and red field with two cercos (rims or hoops) of gold and with a gold eagle in the center.

Another green shield, made like a vase with the eyes and spout and rim of gold.

Another shield with a blue and red field; in the middle is a large plate of gold with six small gold birds around it.

A green shield with a sphere of colored feathers and gold.

A hat of grayish feathers.

A head crest, the end yellow and red, and the feathers of the upper part green, and wide, with much silver embroidery at the ends, and some gold mulberries.

Another head crest of green feathers with five feathers and their gold embroidery on each feather.

Another head crest of green feathers with their gold embroidery.

Another head crest with its green feathers and embroidery of gold.

Another head crest with its green feathers and gold embroidery.

\section{A N D MONOGRA P H S}




\begin{tabular}{|c|c|}
\hline 78 & GOLD S M T T'S A RT \\
\hline$\cdot$ & $\begin{array}{l}\text { Another head crest like the above one. } \\
\text { Another head crest with many birds of divers } \\
\text { colors and much gold embroidery. } \\
\text { Another head crest with its birds and some } \\
\text { roundlets of platted hair and silver and gold } \\
\text { embroidery. } \\
\text { Another head crest of large green feathers, } \\
\text { with gold quills without embroidery. } \\
\text { Another head crest with bohordo (wands?) } \\
\text { and some butterflies and embroidery of gold. } \\
\text { Another head crest of green feathers with } \\
\text { their gold embroidery and some butterflies. } \\
\text { A fan of green feathers, with some hoops of } \\
\text { gold, and some painted figures of men [the fa- } \\
\text { mous feather mosaic] in the center. } \\
\text { A poma of yellow and green feathers, with } \\
\text { much gold embroidery, on a bone. } \\
\text { A cimera (helmet) of green feathers with } \\
\text { some small wheels of gold. } \\
\text { Eighteen pairs of small tufts of green feath- } \\
\text { crs, some with gold embroidery and some with- } \\
\text { out. } \\
\text { A fan with some points of green feathers with } \\
\text { a turtle bone. } \\
\text { Two green birds fastened one to the other. } \\
\text { Four other pairs of head crests and two little } \\
\text { fans of green feathers. } \\
\text { A very large sun of green feathers and in the } \\
\text { center some rays of gold with a red feather. } \\
\text { Report of that which is placed in two other } \\
\text { In one box six rapiers, adorned with gold on } \\
\text { the pommels, hilts, and sheaths. } \\
\text { The case for these rapiers in another box }\end{array}$ \\
\hline & I N I A N NOTES \\
\hline
\end{tabular}


and two abitalles (atabalcs, drums?) and twenty feather-pieces.

Three shields.

The bird which produces the green feathers.

A golden hat.

The bugle.

The stick or staff of gold.

The corselet of gold mail.

Two large feather-pieces.

The portière of figures made in the land.

Three white cloths like damask-clotl.

Three black cloaks.

An image of the kings.

Two stone mosaic-work shields.

Two old corselets. silk.

Five cloths for a bed, like a kind of striped

Fifteen cloths of colors.

Thirty-six shirts.

Two small shawls of red roses.

Another shirt of roses like the shawls.

Report of the Gold, Silver, Jewels, AND

Other Things that the Proctors of New

Spain Carry to His Majesty. (Year of 1525.)

(Archives of the Indies, Patronato, Shelf 1, Box 1.)

Very Powerful Caesar. The gold and jewels and silver and other things which the proctors of this New Spain of the Atlantic bring to Your Majesty, of all that is yours pertaining to the fifth and other rights, is in the following form:

First, thirty thousand pesos of gold in this form (as follows):

\section{A N D MONOGRAPHS}

I. N. M. -2 


\begin{tabular}{|c|c|c|}
\hline 80 & \multicolumn{2}{|c|}{ GOLDSMITH'S ART } \\
\hline . & $\begin{array}{l}\text { In cast and } \\
\text { marked gold .23 } 221 \text { ps. } \\
\text { In six gold shields } \\
\text { that weighed... } 6 \text { \% } 010 \text { ps. } \\
\text { In two gold masks } \$ 401 \text { ps. } \\
\text { In a spear-thrower } \\
\text { of gold like a } \\
\text { staff (bishop's } \\
\text { crozier)........ } \$ 368 \text { ps. } \\
\text { So the aforesaid amount to thi } \\
\text { pesos of gold which the said attorr } \\
\text { Your Majesty. } \\
\text { Item: by the report that we } \\
\text { Majesty it will be seen that there } \\
\text { Your Highness by the right of casti } \\
\text { ing, one thousand, two hundred an } \\
\text { pesos, three tomins, and four grai } \\
\text { which there was given to the silv } \\
\text { casters, one hundred and seventy- } \\
\text { tomins, and two grains: so that the } \\
\text { thousand and ninety-seven pesos, } \\
\text { and two grains, which the said at } \\
\text { to Your Majesty. } \\
\text { Item: One hundred and sixty-t } \\
\text { fine gold, that was obtained from } \\
\text { and re-washings (of the gold) of th } \\
\text { Low-grade Gold } \\
\text { Likewise they take one hund } \\
\text { pesos, two tomins, and one grain } \\
\text { gold, that are from one hundred } \\
\text { four pesos, six tomins, and one } \\
\text { belonged to Your Highness, by } \\
\text { casting and marking, because the }\end{array}$ & $\begin{array}{l}30 \text { \& } 000 \mathrm{ps} \\
\text { rty thousan } \\
\text { eys bring for } \\
\text { end to Your } \\
\text { pertained to } \\
\text { ng and mark } \\
\text { Iseventy-four } \\
\text { ns of gold, of } \\
\text { ersmiths and } \\
\text { six pesos, six } \\
\text { re remain onn } \\
\text { five tomins } \\
\text { torneys carry } \\
\text { hree pesos of } \\
\text { the sweepings } \\
\text { e foundry. } \\
\text { eed and nine } \\
\text { of low-grade } \\
\text { and twenty- } \\
\text { grain, which } \\
\text { the rights of } \\
\text { fifteen pesos, }\end{array}$ \\
\hline & I N D I A N NOT & ES \\
\hline
\end{tabular}


four tomins, that remained, were given to the said silversmiths and casters.

Item: one hundred and thirty pesos of gold from the sweepings and relabes of the said foundry.

The jewels and other things carried to Your Majesty by the said proctors are these:

A head of a duck, of gold, with a greenstone, weighing altogether with the gold, three pesos and four tomins.

Another larger head of a duck of blue stone mosaic-work and a greenstone, weighing with the gold thirty-nine pesos, four tomins.

Two small medals of gold with greenstones, weighing twelve pesos, four tomins.

A flower of stone set in gold like a small bell, weighing twenty-four pesos, four tomins.

A. death's figure of greenstone with certain pendants of stone set in gold, altogether weighing twenty-five pesos.

A medal of gold with a greenstone that appears like the open mouth of an owl, altogether weighing twenty-two pesos, four tomins.

A crab of greenstone and gold, weight fourteen pesos.

A greenstone set in gold having two small gold hands for handles, weighing thirty-eight pesos, four tomins.

Another greenstone with another stone like marble protruding from it, set in gold, weighing twelve pesos.

Another similar stone, weighing with the gold twenty-six pesos, four tomins.

Another greenstone, perforated, with two

\section{AND MONOGRAPHS}




\begin{tabular}{|c|c|}
\hline 82 & GOLD SM I T H'S A R T \\
\hline & $\begin{array}{l}\text { small rings on the back, set in gold, altogether } \\
\text { weighing twenty-six pesos, four tomins. } \\
\text { A head of curly gold, with a face of green- } \\
\text { stones, weighing altogether seventeen pesos, four } \\
\text { tomins. } \\
\text { A head of greenstone, with two ears of green- } \\
\text { stone, with some small pendants, set in gold, } \\
\text { weighing altogether fourteen pesos, four tomins. } \\
\text { A piece of white shell, with a greenstone, } \\
\text { with its pendant of gold at the end [held] with } \\
\text { a gold thread. Not weighed. } \\
\text { Two pieces of gold, such as the natives of } \\
\text { these parts wear in their ears with some red and } \\
\text { blue stones, weighing altogether ten pesos. } \\
\text { A collar of small melons consisting of thirty- } \\
\text { two pieces of greenstones, made so that they } \\
\text { seem to issue from the flower, the flowers and } \\
\text { stalks being of gold, that with the cord on which } \\
\text { they are put, weigh altogether one hundred and } \\
\text { nineteen pesos. } \\
\text { Two bracelets, each one with four eagle's } \\
\text { claws of silver and gold. } \\
\text { Another bracelet with four greenstones set } \\
\text { in gold like the hoof of a stag. Not weighed. } \\
\text { Another bracelet of gold with ten pieces like } \\
\text { a icates, and two claws of greenstone set in gold. } \\
\text { An armlet of tiger-skin with four greenstones } \\
\text { and four small bars of gold of little weight. } \\
\text { Three greenstones and beads with three } \\
\text { little quills of gold in them. } \\
\text { A square greenstone set in gold with certain } \\
\text { pendants of greenstones and gold, weighing } \\
\text { altogether thirty-one pesos. } \\
\text { A shell like a venerica (small scallop-shell) set } \\
\text { in gold with a greenstone in the center. }\end{array}$ \\
\hline & $\cdot$ I N D A N NOTES \\
\hline
\end{tabular}




\section{N V E N T OR I E S}

Another large shell set in gold, with a face of greenstone, with some blue and yellow little stones around the neck.

A butterfly of gold with the wings of venera (scallop-shell), and the body and head of greenstone.

Another vencra set in gold with eyes of an owl and a greenstone.

Another venera like the above, except that it has a red beak and blue ears.

Two veneras, one purple and the other yellow, each one respectively with greenstones in the center and other blue ones around it, set in gold.

Another white vencra like a broncha (poniard or jewel) set in gold.

A head of yellow shell, set in gold.

A butterfly of gold without stones, having some blue and red eyes, weighing eleven pesos.

Another white venera, set in gold, with some greenstones in the center, the one inserted in the other.

Another red venera, set in gold.

An eagle of gold with its pendants and a greenstone in the center, weighing altogether twelve pesos.

A monster of gold with some greenstone mosaic-work in the belly, weighing altogether eleven pesos.

A poniard (or jewel, broncha) of white shell set in gold, weighing altogether thirty-seven pesos, five tomins.

A butterfly of shell, of fancy work, set in gold, weighing altogether eleven pesos, six tomins.

\section{A ND MONOGRAPHS}




\begin{tabular}{|c|c|}
\hline 84 & GOLDSMITH'S ART \\
\hline & $\begin{array}{l}\text { A head of gold, with a face of chalchihuite, } \\
\text { with some pendants of gold, weighing altogether } \\
\text { six pesos. } \\
\text { Two shields of silver, gilded, without brazales } \\
\text { (attachments for the arm), with some bollones, } \\
\text { weighing altogether seven marks, four ounces. } \\
\text { Eight more plain armlets of gilded silver, } \\
\text { weighing altogether two marks, six ounces. } \\
\text { Item: a gilded copper strip with three ro- } \\
\text { dezicas (little wheels) that are worn on the } \\
\text { head, which weighed [weight not mentioned]. } \\
\text { Fourteen more pieces of gilded silver for the } \\
\text { ears, weighing six ounces. } \\
\text { Eighteen shields of low-grade silver, with } \\
\text { some bollones on them, without attachments for } \\
\text { the arms, weighing forty-seven marks, six } \\
\text { ounces. } \\
\text { Item: twenty armlets of low-grade silver, } \\
\text { plain, weighing altogether twenty-three marks, } \\
\text { six ounces. } \\
\text { Also a strip of silver with a little wheel (rode- } \\
\text { zica) on it, weighing two ounces. } \\
\text { Item: three pairs of shoes, such as they wear. } \\
\text { Item: three pairs of leather collars lined with } \\
\text { colored feathers. } \\
\text { Eight more collars of leather, which seem to } \\
\text { be for grayhounds. } \\
\text { Twenty more brazales of leather which the } \\
\text { natives in these parts wear on the arm for } \\
\text { shooting with bows [wristguards]. } \\
\text { Item: eight white armlets of skin. } \\
\text { Twwelve white head-crests of feather-work, } \\
\text { and six blue feathers. } \\
\text { Twelve dozen small tumblers of calabashes. }\end{array}$ \\
\hline & I N I A N NOTES \\
\hline
\end{tabular}




\begin{tabular}{|c|}
\hline I N V E N T O R I E S \\
\hline Half a dozen larger ones painted in various \\
colors. \\
Half a dozen tufted cotton cloths [may also \\
be mantles or blankets]. \\
Another half-dozen cloths of a different kind. \\
Another half-dozen cloths of a different kind \\
and colors. \\
Two bracelets of low-grade gold, with some \\
pieces of black leather. \\
Two other bracelets of low-grade gold, like \\
carrancas [?]. \\
Fifteen little birds' heads, with their pend- \\
ants of low-grade gold, weighing nine pesos, \\
two tomins. \\
Five smallparrots and nine beads of low-grade \\
gold, weighing thirty-eight pesos. \\
Five large lip ornaments, four set in glass \\
[probably quartz], and the other like a snake; \\
they are of low-grade gold. \\
Item: six large garments which can beor are \\
worn also like mantles, painted, and with gold \\
embroidery. \\
Item: six green and white feather-pieces. \\
Two other feather-pieces with some hands \\
placed on them. \\
Two shields of gilded silver with some foliage \\
(showy ornaments, follages) weighing one, \\
twelve marks and four ounces and four reals, \\
the other, eleven marks, six ounces, altogether \\
weighing, twenty-four marks, two ounces, and \\
four reals, which said shields were obtained in \\
the city of Temistitan, and which captain Her- \\
nando Cortés and the people with him, together \\
with the rest of the fifth pertaining to Your \\
Majesty, render to you. \\
Hernando Cortés.-Alonso de Grado. \\
\hline A N D M O N O G R A P H S \\
\hline
\end{tabular}




\begin{tabular}{|c|c|}
\hline 86 & GOLD S M I T'S A RT \\
\hline & 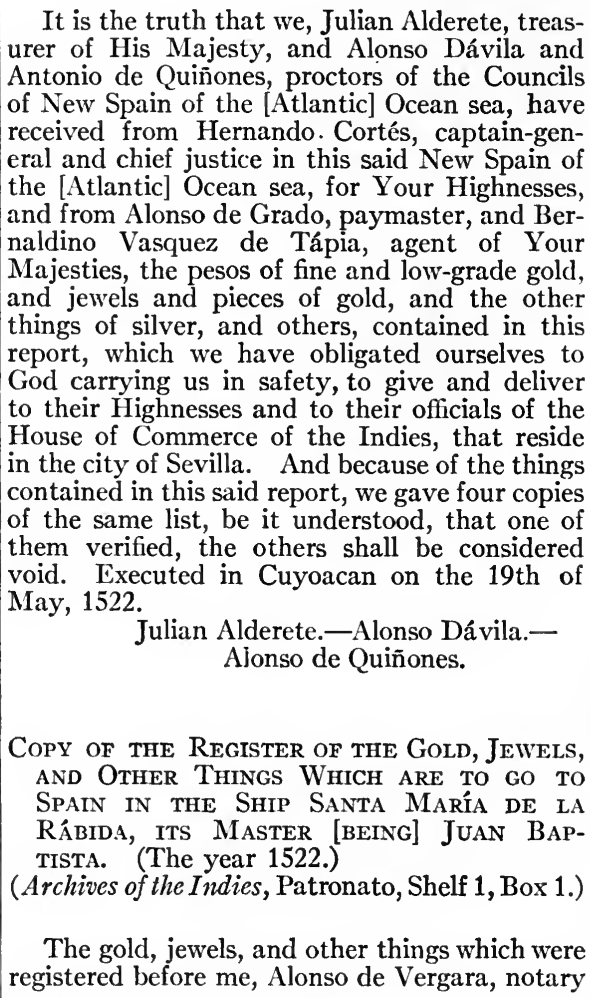 \\
\hline & I N I A N NOTES \\
\hline
\end{tabular}




\section{N V E N T O R I E S}

public and of the Council of this wealthy town of Vera Cruz, which are to go on the ship, God may preserve, which has for name Santa María de la Rábida, of which Juan Baptista is master, and the persons who have registered it, is in the following form:

On the twenty-second of June of the the year fifteen hundred and twenty-two, treasurer Julian Alderete and Alonso Iávila and Antonio de Quiñones proctors who go from this New Spain, who carry in the said ship for their Majesties sixteen thousand two hundred and sixty pesos of fine gold, cast and marked, in which are included certain shields of gold, which also go to His Majesty, and also were registered two hundred and thirty-nine pesos of low-grade gold, that go to His Majesty sent by captain Hernando Cortés and the officials of His Highness who reside in this New Spain.

Registered by the said Alonso Dávila proctor of this New Spain, that on said ship, he takes, as his own (property) six thousand pesos of gold, and other hundred and fifty pesos in jewels.

Antonio de Quiñones, proctor of this New Spain, registered five thousand pesos of gold, cast and marked, as his own property, he carries another five hundred pesos in gold.

Under

239 pesos.

[These] remained in the Azores on the island of Santa María.

Item: Juan de Rivera registered, that he carries for the captain general Fernando Cortés, five thousand pesos of

\section{A ND MONOGRAPHS}




\begin{tabular}{|c|c|c|}
\hline 88 & GOLDSM I'TH'S A R T & \\
\hline $\begin{array}{l}\text { Juan de } \\
\text { Rivera de- } \\
\text { clares that } \\
\text { these eight } \\
\text { h undred } \\
\text { and twenty } \\
\text { five pes os } \\
\text { he gave to } \\
\text { the mari- } \\
\text { ners of the } \\
\text { caravel on } \\
\text { account of } \\
\text { their wages }\end{array}$ & $\begin{array}{l}\text { gold, cast and marked, to give to Martin } \\
\text { Cortés, his father. } \\
\text { Item: the said Juan de Rivera regis- } \\
\text { tered, that he carries for the captain gen- } \\
\text { eral Hernando Cortés, certain jewels of } \\
\text { gold for the said [one] his father, accord- } \\
\text { ing as it is contained in a report signed by } \\
\text { the officials of His Majesty. } \\
\text { The said Juan de Rivera registered } \\
\text { that he carried as his own, four thousand } \\
\text { pesos of gold cast and marked. } \\
\text { The said Juan de Rivera registered that } \\
\text { he carried as his own, certain jewels of } \\
\text { gold according as it is contained in a re- } \\
\text { port signed by the said treasurer. } \\
\text { The said Rivera registered that he car- } \\
\text { ries eight hundred and twenty-five pesos } \\
\text { of gold cast and marked, for wages of } \\
\text { certain mariners who go in this said ship. } \\
\text { The said [Rivera] registered that he } \\
\text { carries for Diego de Ordas, proctor of this } \\
\text { New Spain, four hundred pesos cast and } \\
\text { marked. } \\
\text { The said [Rivera] registered two hun- } \\
\text { dred pesos of gold, which he carries, to } \\
\text { give to Mencia de Roa of Medellin. } \\
\text { Item: the said (Rivera) registered } \\
\text { that hecarries for the heirs of Diego Nieto, } \\
\text { deceased, a citizen of Majadas, one hun- } \\
\text { dred pesos of gold cast and marked. } \\
\text { The said [Rivera] registered that he } \\
\text { carries for an ornament of a church in } \\
\text { Medellin fifty pesos of gold. } \\
\text { The said [Rivera] registered that he } \\
\text { carries sixty marks of silver for certain }\end{array}$ & $\begin{array}{l}400 \\
200\end{array}$ \\
\hline · & I N I A N NOTES & \\
\hline
\end{tabular}


lamps for certain monasteries, which are, Nuestra Señora de Guadalupe, and San Francisco of Medellin, and Nuestra Señora de la Antigua of Sevilla.

Pero Hernandez, tailor, registered, that he carries as his own, two hundred pesos of gold.

Pero López de Balbas registered nine hundred pesos, his own, in cast and marked gold, and sixty pesos in jewels.

Andrés Osorio registered that he carried, as his own, one hundred and forty pesos of gold, cast and marked.

On the twenty-third of June of the said year, Alonso de Benavides registered that he takes as his own property, two thousand five hundred pesos of gold, cast and marked, with a chain that weighed three hundred and forty pesos.

$\mathrm{He}$ also registered that he carried seven marks of silver, his own.

Hernan Peres, pilot, registered that he carried for Francisco de Rosales, mariner, five hundred and two pesos of gold cast and marked, consigned to Luis Hernandez de Alfaro and Juan de Córdova, silversmith, or either one of them.

Said Juan de Rivera registered that he carries certain samples of gold from the mines to be melted, and pearls from the South sea for His Majesty.

The said [Rivera] registered that he carries for Juan de Torres, citizen of Temiztitan, one hundred and twenty

\section{A N D MONOGRAPHS}




\begin{tabular}{|c|c|}
\hline 90 & GOLDSM I TH'S A RT \\
\hline ' & $\begin{array}{l}\text { pesos of gold for his father Antonio de la } \\
\text { Torre. } \\
\text { On June twenty-sixth of the said } \\
\text { year, Francisco de Rosales registered } \\
\text { four thousand three hundred pesos of low- } \\
\text { grade gold, assayed, which he sends with } \\
\text { Juan de Rivera to Luis Hernandez de } \\
\text { Alfaro and Juan de Cordova, citizens of } \\
\text { Sevilla. } \\
\text { In testimony of which, I, the said notary } \\
\text { public, sign it with my name. } \\
\text { Alonso de Vergara, notary public. } \\
\text { Señores: this copy we had taken from the } \\
\text { original register, that remains in our power; we } \\
\text { sign it because it goes with certainty with him. } \\
\text { Alonso Dávila. Antonio de Quinones. } \\
\text { The ship's master and the mariners of the } \\
\text { said caravel, upon oath that they had received } \\
\text { them, declared that they carried the following, } \\
\text { which they declared they received from Juan } \\
\text { de Rivera, in payment of wages which he } \\
\text { owed them for bringing said caravel from Spain, } \\
\text { which said oath was received from them on } \\
\text { said caravel by me, the paymaster, Juan López } \\
\text { de Recalde, on the eighth of November of the } \\
\text { year } 1522 \text {. } \\
\text { The master declared that he brings sixty } \\
\text { pesos of gold. } \\
\text { Hernan Peres, pilot, said that he left in } \\
\text { the Azores, his own and belonging to other } \\
\text { mariners, one hundred and forty pesos. } \\
\text { Francisco Cuervo, pilot, declared that } \\
\text { he brings twenty-five pesos. } \\
\text { Antonio Nicardo, boatswain, declared } \\
\text { that he brought forty pesos. }\end{array}$ \\
\hline & I N I A N NOTES \\
\hline
\end{tabular}


Juan Peres, Portuguese, steward, fifteen pesos.

13 Vicente Fernandez, sailor, mariner, twelve pesos, because he had spent the other thirteen pesos.

Matheo Sanchez, Genoese, twentyseven pesos.

40 pesos Diego del Salto, mariner, said that twenty pesos of his own and fifteen of Astudillo, cabin-boy, he left in the Azores.

10 Anton de Alaras said that he brings fifteen pesos of gold and ten other pesos, on account of his wages of twenty-five pesos, which were spent.

Anton Rodrigues, stationer, and Juan Molinero, mariner.

Pedro Gallego, six pesos.

Juan de Lomayca.

Pablo, cabin-boy, three pesos.

15 Hernando de la Mata said that he received fifteen pesos of his wages and he spent it in clothing.

On the cover it says:

"Copy extracted by the paymaster Juan López de Recalde, from the copy of the register of the gold, and jewels, and other things that were registered in the town of Vera Cruz, that came in the ship named Santa María de la Rábida, of which the master is Juan Baptista, that from the Azores were conveyed in the said caravel, Alonso Dávila and Antonio de Quinones; that on the margins of each entry is written that which came to Sevilla and that which remained in the Azores." (Rubrica.)

\section{A N D MONOGRAPHS}




\begin{tabular}{|c|c|}
\hline 92 & GOLDSM I TH'S A R T \\
\hline . & $\begin{array}{l}\text { COPY OF THAT WHICH UP TO THE PRESENT HAS } \\
\text { PERTAINED TO HIS MAJESTY, OF THE FIITI } \\
\text { AND OTHER RIGHTS. (YEAR OF 1522.) } \\
\text { (Archives of the Indies, Patronato, Shelf 1, } \\
\text { Box 1.) } \\
\text { Very powerful Caesar: that which has, per- } \\
\text { tained to Your Majesty, of the fifth and other } \\
\text { rights, in this New Spain of the Ocean sea, } \\
\text { after we left routed from the city of Temixtitan, } \\
\text { without the four thousand pesos of gold that } \\
\text { was sent to Your Highness with Alonso de } \\
\text { Mendoza, is the following: } \\
\text { First, fifty-two pesos, two tomins, five grains } \\
\text { of gold, of a certain balance made to the person } \\
\text { who had charge of collecting that which per- } \\
\text { tained to Your Majesty. } \\
\text { The sum total of gold that has been melted } \\
\text { from the twenty-fifth of September of the year } \\
\text { 1521 up to today the sixteenth of May, 1522, } \\
\text { [is] one hundred and sixty-four thousand, four } \\
\text { liundred and four pesos, six tomins, of fine } \\
\text { gold, of which there came out one hundred } \\
\text { and sixty thousand, four hundred and one } \\
\text { pesos, seven tomins, of which there pertained } \\
\text { to Your Highness, of the fifth, thirty-one thou- } \\
\text { sand, cight hundred and sixty pesos, three } \\
\text { tomins of gold: the reason we were short of } \\
\text { as much as those five thousand and two pesos, } \\
\text { seven tomins, is because all the gold that was } \\
\text { melted was [set] in pieces or objects that had } \\
\text { much pitch (bitumen). } \\
\text { Item: there pertains to Your Majesty, of } \\
\text { the rights of melting and marking of one hun- } \\
\text { dred and twenty-seven thousand, four hundred } \\
\text { and forty-one pesos, four tomins of gold that }\end{array}$ \\
\hline & I N I I N NOTES \\
\hline
\end{tabular}


remained after taking out the said fifth, for the captain and the conquerors, one thousand two hundred and seventy-four pesos three tomins, four grains of gold.

Item: one hundred and seventy-four pesos from the sweepings and washings of the melting of the said gold.

Item: one hundred and sixty pesos of gold, the fifth of eight hundred pesos of gold which Juan Velásquez de León and Francisco Salzeda, deceased, owed your Highness and the conquerors.

There pertained to Your Majesty five thousand, three hundred and ninety-seven pesos, two tomins, six grains, of the fifth of twenty-six thousand, nine hundred and eighty-six pesos, four tomins, six grains of gold, which were obtained and collected up to today, the said day from the sale of the slaves and other things that were obtained in the war, from the first of January of the year 1521, when the captain and the men that were with him entered into war in the province of Culiacan and the city of Tezcuco and in the other provinces of Mexico and of Temiztitan: which said sale of slaves and other things which pertained to Your Highness and to the conquerors, was made at one time and in the same form, and was collected in presence of the officials of Your Majesty; and the fifth of the said collection amounted to, as said, five thousand, three hundred and ninetyseven pesos, two tomins, six grains.

Item: there pertained to Your Majesty three thousand, one hundred and forty-six pesos, of gold, the value of the slaves that comprised the

\section{A N D MONOGRAPHS}




\begin{tabular}{|c|c|}
\hline 94 & GOLDSMITH'S ART \\
\hline & $\begin{array}{l}\text { fifth in the province of Piaca [Tepeaca?] in the } \\
\text { year } 1520 \text {. Moreover, there pertained to Your } \\
\text { Majesty one thousand and twenty pesos of } \\
\text { gold, that was given by the Indians of the city } \\
\text { of Tezcuco, that are deposited, for the estates } \\
\text { of Your Highness. } \\
\text { Item: Ninety-three pesos of gold, the value } \\
\text { of fourteen loads of cacao, that pertained as the } \\
\text { fifth for Your Highness. } \\
\text { Item: eight pesos, six tomins, of seven loads } \\
\text { of cotton, that pertained to Your Majesty of } \\
\text { the fifth. } \\
\text { Item: three hundred and thirty-three pesos } \\
\text { of gold, the value of certain cotton mantles or } \\
\text { blankets that pertained of the fifth to Your } \\
\text { Majesty. } \\
\text { Item: three hundred and seventy-one pesos, } \\
\text { two tomins, of certain jewels and pieces of gold, } \\
\text { that certain private persons have registered } \\
\text { and which they have in their power up to today. } \\
\text { Item: collected up to today, the said day, the } \\
\text { penalties of the legislature, one thousand one } \\
\text { hundred pesos. } \\
\text { So that all that belongs to Your Highness, } \\
\text { as stated here, amounts to forty-four thousand, } \\
\text { nine hundred and seventy-nine pesos, three } \\
\text { tomins, six grains, of fine gold. } \\
\text { Low-grade gold } \\
\text { There was put in the smelters eighteen } \\
\text { thousand pesos of low-grade gold up to today, } \\
\text { which, being melted, produced seventeen thou- } \\
\text { sand fifteen pesos, four tomins, of low-grade } \\
\text { gold, of which there pertain, as the fifth, to } \\
\text { Your Majesty, three thousand, four hundred } \\
\text { and three pesos, ten grains. }\end{array}$ \\
\hline & INIIAN NOTES \\
\hline
\end{tabular}


Item: from the rights of the smelters and the marking of the said gold, one hundred and twenty-four pesos, six tomins, one grain.

From the sweepings and washing of the said low-grade gold.

From a certain balance that was made to the person in charge of collecting that which pertained to Your Highness.

So that the low-grade gold pertaining to Your Majesty amounts to three thousand, six hundred and eighty-nine pesos, six tomins, eleven grains.

There has pertained to Your Highness from the said day until the present day, thirty-five marks, five ounces of gold, from the fifth one hundred and seventy-eight marks, five ounces, which have been obtained.

Item: two shields of gilded silver with some gaudy ornaments which weigh, the one, twelve marks, four ounces, four reals, and the other eleven marks five. . . . that all together [weigh] twenty-four marks, two ounces, four reals, which said shields were obtained in the city of Temiztitan and captain Hernando Cortés and the conquerors of this New Spain wish to present together with the rest of the fifth that pertains to Your Highness.

In addition to the gold and silver contained in this report there pertained to Your Majesty the fifth of the jewels and pieces of gold and stones and other things, and according to the manner as declared and signed by our names in the report that is sent to Your Highness with the present, of the gold and things which we send to you, and which are also signed by our

\section{AND MONOGRAPHS}

1. N. M. -2 


\begin{tabular}{|c|c|}
\hline 96 & GOL D S I T H'S A R T \\
\hline . & 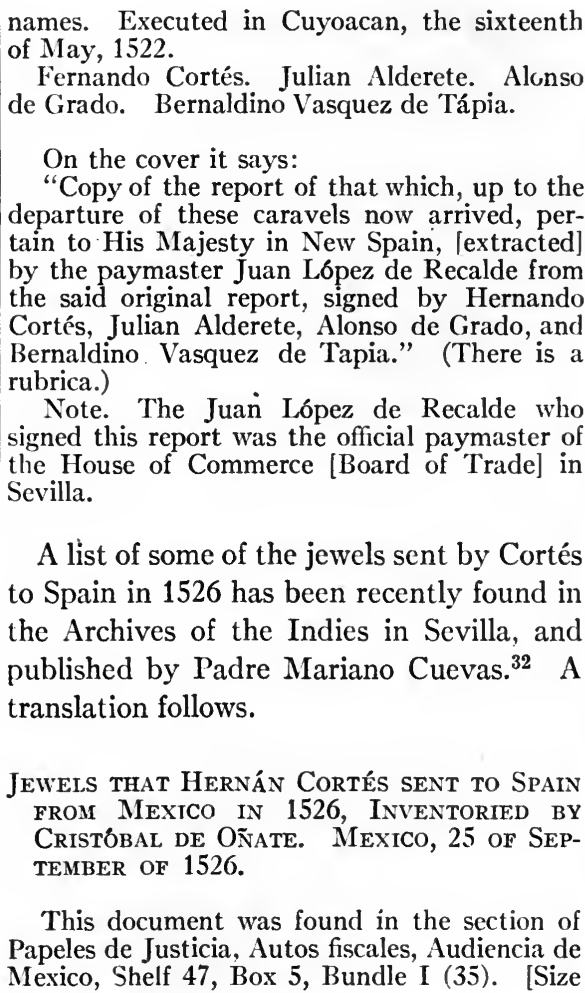 \\
\hline & I N I A N NOTES \\
\hline
\end{tabular}




\section{N V E N T O R I E S}

of paper $300 \times 210 \mathrm{~mm}$. Watermark: hand and flower with six petals.].

I, Christoval d'Oñate, paymaster in this New Spain for the paymaster Rodrigo de Albornoz, state and give testimony that in the city of Tenuxtitán on the twenty-fifth day of the month of September of the year fifteen hundred and twenty-six, the governor Don Hernando Cortés registered the following jewels:

A set of a rapier that has two heads of eagles for pommels, and two feet of eagles for hilt, and a round haft and two pieces for the center of the knife of netting.

A large chape [of a scabbard].

An owl with six pendants.

A girdle with seven pendants, and a little eagle and two rings attached to the flaccid part of the girdle.

Two large ear ornaments.

A pyx with a crucifix and images of Our Lad. and St John stamped on it.

Also several strings of beads and several little birds, and a large rosette.

A shield with sixteen pendants.

A Flemish bag with several small fish for pendants.

Thirty-four large and round beads, and thirty-three beads in another string.

A necklace of turtles that has eighteen pieces with their pendants.

Another necklace of small cocumatle [cuçumatl, weasel] heads that has thirty-five pieces.

Two boxes [made] of turtles [shells], and a large flying fish.

\section{A ND M ONOGRA P H S}




\begin{tabular}{|c|c|}
\hline 98 & GOL D S I TH'S A R T \\
\hline . & $\begin{array}{l}\text { A lizard with wings. } \\
\text { A small necklace that contains twenty-five } \\
\text { pieces with their pendants. } \\
\text { A sQcumatle (weasel) set in a turtle. } \\
\text { A shell with a berineco [?], and a little lion } \\
\text { with a chalchihuite on the back. } \\
\text { A young eagle with a brood also on the back. } \\
\text { A cocumatle with a greenstone in the belly. } \\
\text { A string of small tubes and of worms [?] that } \\
\text { contains thirty-eight pieces and their pendants. } \\
\text { A string of very small beads with some bells } \\
\text { forming the extremities, with a small medal at } \\
\text { the end with a chalchihuite. } \\
\text { A rose (rosette) with its pendants, and a } \\
\text { shield with arrows and pendants. [This seems } \\
\text { to describe the gold jewel shown on pl. I.] } \\
\text { Some strings of round and oval beads, and } \\
\text { among them four butterflies and an eagle with } \\
\text { pendants on the tail. } \\
\text { Two butterflies with two chalchihuites on } \\
\text { the backs. } \\
\text { Forty-two long beads like tubes, with a medal } \\
\text { at the end with its pendants. } \\
\text { Forty-six round beads and twenty-nine long } \\
\text { ones on a string. } \\
\text { Two images. } \\
\text { A small shield, a chalchihuite at the end and } \\
\text { two pendants hanging from it. } \\
\text { A rose (rosette) of gold and silver with a } \\
\text { chalchihuite in the center. } \\
\text { Another rose (rosette) with a butterfly in } \\
\text { the center. } \\
\text { A rosary that contains sixty beads made in } \\
\text { a string with two large fishes among them with } \\
\text { wings and a large cicada. }\end{array}$ \\
\hline & INDIAN NOTES \\
\hline
\end{tabular}


A string that contains twenty-two long beads and twenty-six round ones and a rose (rosette) of gold and silver at the end.

Another large rose (rosette) with a chalchihuite in the center that has the figure of a man carved in the chalchihuite.

Twenty-five large tubes (bugles).

A little eagle with some chalchihuites and pendants hanging from the breast.

A string of long and round beads containing forty pieces.

A rose (rosette) with a chalchihuite in the middle and ninety-six long and round beads in a string.

A small chain of long links and a crucifix at the end.

A rrenaquajo [arentadpole herring?] and a çocumatle (weasel) with a chalchihuite in the breasts.

Four pendants.

Three rings with three little eagles.

Two rings with the heads of owls.

Two others with two roses (rosettês).

A girdle with four pendants.

Thirteen rings with turquoises, and one with a greenstone, and another with a red stone, and two others without stones, and another with a little eagle, and two heads of goalteca [?].

A jar with two expansions with its foot [and] with two handles.

A xicala (jicara, gourd chocolate-cup) with a stirrer.

A cross with a crucifix and its support.

A small jar with a handle.

A girdle with the said pendants and a rose (rosette) with the head of a tiger in the center.

\section{A ND MONOGRAPH S}




\begin{tabular}{|c|c|}
\hline 100 & . GOLDSMITH'S A R T \\
\hline \multirow[t]{2}{*}{ - } & $\begin{array}{l}\text { A medal made like a sun with a carved clial- } \\
\text { chihuite, in the center a shield with thirteen } \\
\text { pendants and some greenstones in the middle. } \\
\text { A scorpion with a chalchihuite in the body } \\
\text { and a snake coiled round with a chalchihuite } \\
\text { in the middle with nine pendants. } \\
\text { A rose (rosette) with the head of an Indian } \\
\text { with six pendants. } \\
\text { A bird with a chalchihuite in the breast. } \\
\text { Another coiled serpent with a chalchihuite } \\
\text { and a pearl in the middle, and a cross on the } \\
\text { back, with its pendants. } \\
\text { A tiger with eighteen beads on a cord. } \\
\text { Two bags with some pendants, like triaqueras } \\
\text { (medicine pots). } \\
\text { A little cicada with two chalchihuites, one } \\
\text { in the head and the other in the body, and three } \\
\text { small turquoises in the tail. } \\
\text { An eagle and a tiger united the one with the } \\
\text { other, and a carved stone on the breasts. } \\
\text { A medal like a rose (rosette), with five } \\
\text { pendants with forty-four little tubes of gold. } \\
\text { Another medal with two pendants and sixty- } \\
\text { four oval and round beads. } \\
\text { Fifty beads shaped like small tubes, and } \\
\text { round ones and a piece of leaf. } \\
\text { An eagle of two heads, and in the middle of } \\
\text { it a crucifix with several pendants, forty-six } \\
\text { oval and round beads. } \\
\text { A cocumatle (weasel) with several roses } \\
\text { (rosettes) in the forefeet and a hole in the belly. } \\
\text { A tiger with two eagles, and thirty-six beads, } \\
\text { all on a cord, and a girdle with nine pendants. } \\
\text { A slab of red [red may be a weight for nets?] }\end{array}$ \\
\hline & I N I A N NOTES \\
\hline
\end{tabular}




\section{N V E N T O R I E S}

and on it a crucifix of silver and Our Lady on the other side.

Four pendants.

$A$ rose (rosette) with a chalchihuite in the center.

A coiled snake with seven pendants.

Another coiled snake with a movable tail.

Thirty-nine oval beads and a girdle with three pendants.

$A$ rose (rosette) with a sprig of small tiny stones.

A string of beads containing one hundred and five small tubular and round beads.

Another small string that contains twentysix beads of the same kind although a little smaller.

Another string of beads containing sixtysix small tubular and round beads, and several little worms [gusanillos may also be gold or silver twisted threadl for pendants.

A small crucifix with a cross.

A small hand with a tiger coming out of it.

Another large crucifix with a crooked cross, with three chalchihuites on the back of the cross, and forty-eight beads made like little bells.

'Two toothpicks, each with four little pieces.

All of gold which weighed two thousand, three hundred and fifty-nine pesos, from which the fifth and equity pertaining to His Majesty were paid, and of which the said Christoval Donate gives testimony.

Dated the first of October of the said year one thousand five hundred and twenty-six.

Christoval de oñate (rubric)

\section{A N D MONOGRAPHS}




\begin{tabular}{|c|c|}
\hline 102 & GOLDSM ITH'S ART \\
\hline & $\begin{array}{l}\text { On the back we read: "The Lords of the } \\
\text { Council ordained that I should place this } \\
\text { testimony in this process at Burgos the XVIII } \\
\text { of January, the year IUDXXVIII [1528]." } \\
\text { There is a rubrica. } \\
\text { It has been demonstrated by the state- } \\
\text { ment of Bernal Díaz, and especially by a } \\
\text { study of the lists of the great Aztecan loot, } \\
\text { that by far the greater part of the gold } \\
\text { treasure gathered by Montezuma for the in- } \\
\text { vading Cortés and his fellow Spaniards went } \\
\text { at once to the crucible to be melted into bars } \\
\text { for immediate division. Of this, the King } \\
\text { of Spain received his royal fifth and a certain } \\
\text { other small proportion of the spoils, the } \\
\text { greater part being retained by Cortés and } \\
\text { his companions. Of all the priceless relics } \\
\text { of ancient Mexican art, such as gold, jew- } \\
\text { els, stone mosaics, and the unique feather } \\
\text { mosaic-work, which were not destroyed, but } \\
\text { sent to Spain as treasure or curiosities, prob- } \\
\text { ably fewer than two score of these objects } \\
\text { are to be found today in Europe. During } \\
\text { the passing four centuries, the melting-pot, } \\
\text { careless hands, and moths, have each con- } \\
\text { tributed to carry to oblivion visual knowl- }\end{array}$ \\
\hline & INDIAN NOTES \\
\hline
\end{tabular}




\begin{tabular}{|c|c|}
\hline I N V E N T OR I E S & 103 \\
\hline $\begin{array}{l}\text { edge of these arts. Of the jewels of gold } \\
\text { sent to Europe by Cortés and others, enu- } \\
\text { merated in thelistspresented above, no speci- } \\
\text { mens are extant. Of stone mosaic-work on } \\
\text { wood, in which gold often enters as part of } \\
\text { the decoration, two dozen pieces are on } \\
\text { record as being extant, while the wonderful } \\
\text { feather-mosaics with gold are represented } \\
\text { by four or five examples. A single ancient } \\
\text { feather-mosaic shield hangs on a wall of } \\
\text { the Museo Nacional in the City of Mexico. } \\
\text { Of all this enormous quantity of gold cast } \\
\text { and hammered into jewels and other objects } \\
\text { of high esthetic merit, as we have said, no } \\
\text { examples are now known to exist in Europe. } \\
\text { Our meager knowledge of the character of } \\
\text { this art must be derived from the inventories } \\
\text { we have given, and from specimens found in } \\
\text { graves in recent years, some of which will be } \\
\text { described and illustrated in this monograph. } \\
\text { Robertson, in his History of America, writ- } \\
\text { ten at the close of the eighteenth century, } \\
\text { mentions a gold cup in England. He writes: } \\
\text { "The only unquestionable specimen of } \\
\text { Mexican art that I know of in Great Britain } \\
\text { is a cup of very fine gold, which is said to have }\end{array}$ & \\
\hline AND MONOGRAPHS & \\
\hline
\end{tabular}




\begin{tabular}{|c|c|}
\hline 104 & GOLDSM I'TH' S A R T \\
\hline & $\begin{array}{l}\text { belonged to Montezuma. It weighs five ounces } \\
\text { twelve dwt. 'Three drawings of it were ex- } \\
\text { hibited to the Society of Antiquaries, June } 18 \text {, } \\
1765 \text {. A man's head is represented on the cup. } \\
\text { On one side the full face, on the other the profile, } \\
\text { on the third and back, part of the head. The } \\
\text { relievo is said to have been produced by punch- } \\
\text { ing the inside of the cup so as to make the } \\
\text { representation of a face on the outside. The } \\
\text { features are gross, but represented with sone } \\
\text { degree of art, and certainly too rude for Spanish } \\
\text { workmanship. This cup was purchased by } \\
\text { Edward, Earl of Oxford, while he lay in the } \\
\text { harbour of Cadiz." } 33\end{array}$ \\
\hline & $\begin{array}{l}\text { According to Humboldt }{ }^{34} \text { this gold cup } \\
\text { was in the possession of Lord Archer, and } \\
\text { was reputed to have belonged to Monte- } \\
\text { zuma. Its present whereabouts are un- } \\
\text { known to the writer. From the description } \\
\text { we are reminded more of Peruvian than of } \\
\text { Mexican work, and many gold cups of this } \\
\text { type from Peru and Bolivia are to be found } \\
\text { in various museums and private collections }\end{array}$ \\
\hline \multirow[t]{3}{*}{ - } & SOURCES OF GOLD \\
\hline & $\begin{array}{l}\text { Cortés was informed by Montezuma, ac- } \\
\text { cording to Bernal Díaz, that gold was ob- } \\
\text { tained from- }\end{array}$ \\
\hline & I N I A N NOTES \\
\hline
\end{tabular}




\section{SOURCES OF GOLD}

"three places, but they usually brought most of the gold from a province named Zacatula [now called the Rio Balsas, in Guerrero], which is on the south coast ten or twelve days' journey from that city [Mexico]. The gold was collected in xicales (gourds) by washing away the earth, so that after the earth was washed away some grains of the gold remained. At the present time they also brought it to him from another province called Tustepec, near where we disembarked on the north coast where it was gathered from two rivers. Near that province there were other good mines in a land that was not subject to him, named the land of the Chinantecs and Zapotecs, who did not obey his rule." 35

Cortés, in his second letter to the King, despatched from Mexico, enters into greater detail. He writes:"

"I prayed him [Montezuma] so that I might. give a better account to Your Majesty of this country, to show me the mines from which he obtained gold, and he answered with perfect good will that he would gladly do so. He immediately sent certain of his servants, distributing them two by two over four provinces. from which he said he got the gold; and he asked me to send Spaniards with them, to see how it was taken out. So, for each of his own people, I sent two Spaniards, and some went to a province called Cuzula, eighty leagues from the great city of Temixtitan, the natives of which

\section{A N'D MONOGRAPHS}




\begin{tabular}{|c|c|}
\hline 106 & GOLDSMITH'S ART \\
\hline 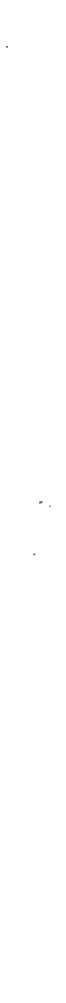 & $\begin{array}{l}\text { are his vassals, and there they were shown three } \\
\text { rivers, from each of which they brought me some } \\
\text { specimens of gold of very good quality, although } \\
\text { it was taken out with mean tools, as they had } \\
\text { only those with which the Indians extract it. } \\
\text { On the road they passed through three provinces, } \\
\text { according to what the Spaniards said, of very } \\
\text { fine land, and many hamlets and cities, and } \\
\text { towns, very populous, and containing buildings } \\
\text { equal to any in Spain. They told me especially } \\
\text { of a house and fort, greater, stronger, and better } \\
\text { built than the castle of Burgos, and that the } \\
\text { people of this province, called Tamazulapa, } \\
\text { were better dressed than any others we have } \\
\text { seen, and, as it seemed to them, more intelli- } \\
\text { gent. Others went to another province called } \\
\text { Malinaltepeque, another seventy leagues from } \\
\text { the said city, and more toward the seacoast; } \\
\text { and they brought me likewise specimens of } \\
\text { gold from a great river there. The others went } \\
\text { to a country called Teniz, farther up this } \\
\text { river, belonging to a people of a different lan- } \\
\text { guage from that of Culaa and the ruler of that } \\
\text { country is called Coatelicamat. His country } \\
\text { lies in a very high rugged mountain-chain, and } \\
\text { it is not subject to Montezuma; the people of } \\
\text { that province are very warlike, fighting with } \\
\text { lances, twenty or thirty palms long, and, } \\
\text { because they are not vassals of Montezuma, } \\
\text { the messengers did not dare enter that country } \\
\text { without first notifying the chief and asking his } \\
\text { permission. They told him they had come } \\
\text { with the Spaniards to see the gold mines in } \\
\text { his country, and besought him, on my part and } \\
\text { that of Montezuma, their lord, to permit it. }\end{array}$ \\
\hline & I N I A N NOTES \\
\hline
\end{tabular}




\section{SOURCES OF GOLD}

Coatelicamat answered that he was very willing the Spaniards should come into his country and see the mines, and whatever else they wished, but that the Culúans, who were subject to Montezuma, must not come, because they were his enemies. . . . At last they determined to go alone, and the lord and his people received them very well, and showed them seven or eight mines where they took out gold; and in their presence the Indians took some out of which they brought me some specimens. Coatelicamat sent me certain messengers with the Spaniards, offering himself and his country for the service of Your Majesty; and he sent me certain valuables of gold, and such wearing apparel as they have. The others went to another province, called Tuchitepeque, which is almost in a direct line toward the sea, twelve leagues beyond the province of Malinaltepeque, where, as I have already said, gold had been found. Two other rivers were shown them there, where gold is also found." 36

There were no mines. Nuggets of gold were found on the surface, but the principal source was the sands of the river-beds. It was kept in the form. of dust in small cane tubes or quills, or was melted in small pots by the aid of hollow reed blowpipes, and cast in bars.

\section{A ND MONOGRAPHS}




\begin{tabular}{|c|c|}
\hline 108 & GOLDSMITH'S A R T \\
\hline & $\begin{array}{l}\text { USES OF GOLD } \\
\text { Gold formed a part of the yearly tribute } \\
\text { paid by the southern provinces of ancient } \\
\text { Mexico to the Aztec kings of Tenochtitlan, } \\
\text { and we have the pictorial representation of } \\
\text { such tribute preserved in an original codex } \\
\text { on maguey paper, which depicts the objects. } \\
\text { hieroglyphs for the quantities paid, and } \\
\text { hieroglyphs for the names of the towns upon } \\
\text { which the gold tribute was levied. This } \\
\text { codex is called the Tribute Roll of Monte } \\
\text { zuma. }{ }^{37} \text { The gold was paid in dust kept in } \\
\text { gourds or cane tubes, and in bars. Manu- } \\
\text { factured articles are shown in the codex in } \\
\text { the form of diadems and head-bands, as } \\
\text { well as bells, circular breast ornaments, lab- } \\
\text { rets or lip plugs, and round beads. } \\
\text { On pl. xvil of the Peñafiel edition of the } \\
\text { Tribute Roll, }{ }^{38} \text { are ten yellow bars described } \\
\text { as being four fingers in width, three-fourths } \\
\text { of a vara in length, and of the thickness of } \\
\text { parchment. In the edition of Lorenzana } \\
\text { is the legend in Nahuatl, "Teocuitlatl coztic } \\
\text { matlactli," meaning "ten yellow gold things." } \\
\text { A yellow vessel with a flag (fig. 1), the sign }\end{array}$ \\
\hline & I N D I N NOTES \\
\hline
\end{tabular}




\section{USES OF GOLD}

for twenty, means the payment of twenty gourd vessels of gold dust. In the Lorenzana edition, this item bears the legend, "Centec pantli inxalli teocuitlatlcoztic initlacallatl," translated by him as "certain measures or tecomates (gourds) filled with gold-dust." The names of places which suggest the towns paying gold

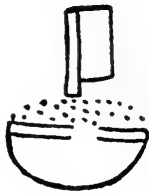

Fig. 1. tributes are, Acocozpa, "in the yellow water;" Acuitlapan, "in the place of gold," and Chipetlan, "place of the

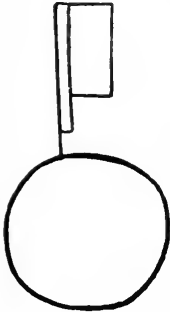

FIG. 2. terrible god Xipe Totec."

On pl. xvin the page is divided into three sections, and in the third group are represented two yellow discs, each having the sign for twenty above (fig. 2). The legend in Lorenzana is, "Ontecpantlatematli coztic," the record being, forty gold discs, and the place paying this tribute may be Ixicayan, "where the water goes down."

On pl. xxI is a record of the payment of

\section{A N D MONOGRAPH S}




\begin{tabular}{|l|l|}
\hline 110 & \multicolumn{1}{|c|}{ G O L D S M I T H S A R T } \\
\hline twenty gourds filled with gold-dust. Eleven \\
towns are represented on this page. They \\
are: (1) Coixtlahuacan, (2) Texopan, (3) \\
Tamozolapan, (4) Yancuitlan, (5) Tepuzcu- \\
lulan, (6) Nochistlan, (7) Xaltepec, (8) \\
Tamazolan, (9) Mictlan, (10) Coaxomulco, \\
$\begin{array}{l}\text { (11) Cuicatlan. The first town is north of } \\
\text { the Mixteca in the Chocho territory. } \\
\text { Towns numbered 4, 5, 6, and 8 are in the } \\
\text { Mixteca territory, 3 is in the Mixe region, } \\
\text { appears to be in the same region, 11 is in } \\
\text { the valley east of the Mixteca, and Mitla } \\
\text { is the site of the famous ruins in Zapotecan } \\
\text { territory. The legend in Lorenzana is, } \\
\text { "Teocuitlatl coztic centec pan xicalli," being } \\
\text { twenty jicaras (gourds) of yellow gold. } \\
\text { A list of tributes paid by towns in the } \\
\text { valley of Oaxaca is shown on pl. xxIr. } \\
\text { Seven of these towns may be identified with } \\
\text { present settlements, still bearing the ancient } \\
\text { names in the Nahuatl language. The first } \\
\text { is Coyollapan, probably Cuilapam; the sec- } \\
\text { ond is Etlan, now known as Etla; the fourth } \\
\text { is Huaxayac, or Oaxaca; the fifth Camotlan, } \\
\text { but there are at present four Camotlans in } \\
\text { the state, and none of this name at present }\end{array}$ \\
\hline I N D I A N N O T E S \\
\hline
\end{tabular}




\section{USES. OF GOLD}

exists in the valley. The most significant place is the sixth on the list, Teocutlan, properly Teocuitlan, meaning, "the place where gold is found," represented in the hieroglyph place-name by a bare arm with a stream of water flowing from the hand, and placed against it is the sign for gold. The eighth is Ocotlan, near which town there are now worked rich gold mines. The ninth, Tetipac; tenth, Tlacueychahayan, evidently Tlacochahuaya; and the eleventh Macuilxochitl. From this region was sent to Montezuma twenty large gold plaques. The legend given by Lorenzana is "Centec pantli coztic teocuitlacomalli," being translated as "twenty comallis [a comalli being the clay pan or griddle of circular form] of yellow gold." A note in the Peñafiel edition says they were the size of average plates and the thickness of the thumb, and he adds that this page represents the tribute paid by the ancient Zapotecan kingdom.

Between pages xxii and xxiii of the Peñafiel edition it is evident that a page is missing in the original maguey paper codex. In the edition of Kingsborough, ${ }^{40}$ which was

\section{A N D MONOGRAPHS}




\begin{tabular}{|c|c|}
\hline 112 & GOLDSMITH'S ART \\
\hline & $\begin{array}{l}\text { made from the copy on European paper } \\
\text { called the Codex Mendoza, pl. } 47 \text { and } 48 \\
\text { represent the two sides of this missing leaf. } \\
\text { It was evidently abstracted from the original } \\
\text { painting at some early time, as it is missing } \\
\text { also in the edition of Lorenzana published } \\
\text { in } 1770 \text {. On page } 48 \text { are the representations } \\
\text { of twenty-two towns in the hot country pay- } \\
\text { ing a considerable quantity of works in gold. } \\
\text { These towns are: Tochtepec, Xayaca, Otla- } \\
\text { titlan, Cocamaloapa, Mixtlan, Michapan, } \\
\text { Ayotzintepec, Michatlan, Teotlitlan, Xical- } \\
\text { tepec, Oxitlan, Tzinacanoztoc, Tototepec, } \\
\text { Chinantlan, Ayocintepec, Cuezcomatitla, } \\
\text { Puetlan, Teteutlan, Yxmatlatlan, Yautlan. } \\
\text { Toztlan, and Tlacotlal. The gold tributes } \\
\text { shown are: a gold shield; a diadem of gold, } \\
\text { being made of flexible gold like the copilli } \\
\text { or crown worn by the kings as depicted in } \\
\text { many Mexican codices; a broad band for } \\
\text { the head, a hand-breadth wide and of the } \\
\text { thickness of parchment; two strings of gold } \\
\text { beads, one of which has six bells inter- } \\
\text { spersed; twenty becotes (labrets or long } \\
\text { lip-plugs) of clear amber enchased with } \\
\text { gold at the lower end; and twenty beçotes }\end{array}$ \\
\hline & I N I A N NOTES \\
\hline
\end{tabular}




\section{USES OF GOLD}

of crystal "with a blue matrix and enchased with gold."

On pl. xxill is the tribute from the province of Soconusco in the present state of Chiapas. The towns in this hotland region also sent lip-ornaments, and we find represented in the Peñafiel and Lorenzana editions, two yellow labrets. The legend above one in Lorenzana is "Ome Tezcatl," "two columns of fine stone." Above the other is "Tezcatl," with the caption in Spanish, "columns of alabaster or other special stones." In Kingsborough they are described as. "beçotes of clear amber enchased with gold."

The last objects of gold shown in the Tribute Roll are on pl, xxv. The places paying this tribute are in the hotlands of the state of Vera Cruz. Two labrets, with the sign for twenty above each, are painted. The first one is green in the Peñafiel edition (painted blue in Kingsborough), with a yellow band on the upper part. The second is brown (yellow in Kingsborough), with the upper section yellow. They are described in Kingsborough as "twenty beçotes

\section{A N D MONOGRAPHS}




\begin{tabular}{|l|l|}
\hline 114 & \multicolumn{1}{|c|}{ G O L D S M I T H ' S A R T } \\
\hline $\begin{array}{l}\text { of beryl with a blue matrix enchased with } \\
\text { gold," and "twenty beçotes of clear amber } \\
\text { enchased with gold." } \\
\text { It was a custom, when kings, priests, } \\
\text { war chiefs, or other important persons } \\
\text { died, to bury them with their gold jewels } \\
\text { and other objects, although in some parts } \\
\text { of the country cremation was practised. } \\
\text { Concerning burial, the Anonymous Con- } \\
\text { queror writes: } \\
\text { "They made a pit in the earth with walls of } \\
\text { rough stone and mortar, in which they place } \\
\text { the dead seated in a chair. At his side they } \\
\text { placed his sword and shield, burying also cer- } \\
\text { tain jewels of gold. I helped to take from a } \\
\text { sepulcher jewels worth three thousand castella- } \\
\text { nos."4l } \\
\text { The idols representing the various deities } \\
\text { were often ornamented with jewels of gold } \\
\text { made with a mosaic of precious stones. } \\
\text { Andres de Tápia describes an idol, probably } \\
\text { that of Huitzilopochtli, which he says } \\
\text { was the size of a large man, made of a mass } \\
\text { composed of seeds ground and kneaded } \\
\text { together with the heart's blood of sacrificed } \\
\text { children, and in this kind of dough were } \\
\text { placed many gold jewels. He describes }\end{array}$ \\
\hline$\quad$ I N D I A N N O T E S \\
\hline
\end{tabular}




\begin{tabular}{|l|}
\hline U S E S O F G O L D \\
\hline two other idols of stone almost three yards \\
high- \\
"the stone covered over with mother-of-pearl, \\
and over this, fastened with bitumen like a \\
paste, were [set in] many jewels of gold, and \\
men, snakes, birds, and histories [hieroglyphs?] \\
made of small and large turquoises, of emeralds \\
and amethysts, so that all the mother-of-pearl \\
was covered, except in some places where they \\
left it [uncovered] so as to make work with \\
the stones. These idols had some plump snakes \\
of gold [as] girdles, and for collars each [one \\
had] ten or twelve hearts made of gold, and for \\
the face a mask of gold and eyes of mirror \\
[obsidian or iron pyrites]." 42 \\
\begin{tabular}{l} 
It has also been stated by some writers \\
that the interior of their temples were \\
decorated with gold, but this use of gold \\
has not been substantiated. Herrera, how- \\
ever, tells us that gold bells were used on \\
their doors. He says they used certain \\
mats made of bamboo to close the entrances \\
to their houses, that might be easily removed \\
or replaced. Attached to them were bells \\
of copper and of gold, or some other metal, \\
and marine shells, in order to make a noise \\
when they removed them or opened or \\
closed the doors. ${ }^{43}$ \\
\hline A N D M O N O G R A P H S
\end{tabular} \\
\hline
\end{tabular}




\begin{tabular}{|c|c|}
\hline 116 & GOLDSM I TH'S ART \\
\hline & $\begin{array}{l}\text { There are references to gold in the poetry } \\
\text { of the ancient Mexicans. These examples } \\
\text { will suffice from the material at hand. In } \\
\text { the treatise on the Mexican language by } \\
\text { Father Horacio Carochi, the best of the } \\
\text { early grammarians, } 4 \text { is the strophe "Xiuh- } \\
\text { coyolizitzilica in teotcuitlahuchuetl," trans- } \\
\text { lated by Carochi into - Spanish as "el } \\
\text { atambor de plata suena como cascables de } \\
\text { turquesa." Freely rendered into English } \\
\text { it is, "the silver drum sounds like bells of } \\
\text { turquoise." Brinton has pointed out care- } \\
\text { lessness in the Spanish translation, for the } \\
\text { Nahuatl word is clearly not silver, but gold. } \\
\text { Brinton gives it as "the golden drums tur- } \\
\text { quoise-bell tinkling." } 45 \text { In a song published } \\
\text { by Brinton, called an "Otomi song of the } \\
\text { Mexicans," occurs the line, "I shall speak } \\
\text { forth my song like the tinkling of golden } \\
\text { bells," } 46 \text { and again in the same song is the } \\
\text { strophe, "In the true spirit of song I lifted } \\
\text { my voice through a trumpet of gold." } \\
\text { Another poetic reference to gold is found } \\
\text { in the song to the god of the goldsmiths, } \\
\text { Xipe Totec. As translated from the } \\
\text { Nahuatl by Seler, it reads, "The nightly }\end{array}$ \\
\hline & I N I A N NOTES \\
\hline
\end{tabular}




\begin{tabular}{|l|}
\hline A Z T E C G O L D S M I T H S \\
\hline \begin{tabular}{l} 
drinker, why art thou angry? Put on thy \\
disguising, the golden garment; clothe thy- \\
self in it.'47 \\
THE AZTEC GOLDSMITHS AND THEIR \\
WORK \\
The origin of the goldsmith's art is \\
attributed by the Aztecs to the Toltecs, \\
their predecessors in the valley of Mexico, \\
and its invention and improvement has \\
been assigned by them to the culture hero, \\
who later became the great beneficent god \\
Quetzalcoatl, who was worshiped through- \\
out central Mexico, and whose chief seat \\
of worship was in Cholula, the great pyra- \\
mid, or teocalli, still to be seen there, having \\
been erected in his honor. \\
The center of the goldsmiths was the \\
town of Atzcapotzalco, a league northwest \\
of Tenochtitlan. It was the capital of the \\
Tepanecos when the Aztecs came into the \\
valley of Mexico. These artisans were \\
famed throughout Mexico, and Bernal \\
Diaz says that even the great goldsmiths \\
of Spain were forced to admire their work. \\
The profession was a highly honorable one, \\
\hline A N D M O N O G R A P H S
\end{tabular} \mid \\
\hline
\end{tabular}




\begin{tabular}{|c|c|}
\hline 118 & GOLDSMITH'S ART \\
\hline & $\begin{array}{l}\text { and its members formed a respectable body } \\
\text { held in great esteem. They had a special } \\
\text { veneration for the god Xipe, their tutelar } \\
\text { deity, and held a festival in his honor during } \\
\text { the second month of the ancient Mexican } \\
\text { year, accompanied with human sacrifice." } \\
\text { The great favor in which the trade was } \\
\text { held is indicated by the stringent laws con- } \\
\text { cerning the theft of gold. If a person was } \\
\text { convicted of stealing either gold or silver, } \\
\text { he was severely punished, the theft of gold } \\
\text { being considered a direct insult to the god. } \\
\text { In fact, the Nahuatl or Mexican word for } \\
\text { gold is teocuitlatl, a compound of teatl, } \\
\text { "god," and cuitlall, "excrement," meaning } \\
\text { "excrement of the gods," or "divine excre- } \\
\text { ment." } 49 \text { The usual penalty for the offence } \\
\text { was that the person, if found guilty, should } \\
\text { be kept until the annual festival of Xipe } \\
\text { Totec, "Our Lord the Flayed," when he } \\
\text { was sacrificed to that deity, being flayed } \\
\text { alive by the priest.50 } \\
\text { Gold, silver, and other metals, as well } \\
\text { as precious stones and feather-work, and } \\
\text { jewels made from these materials, were } \\
\text { daily sold in Tenochtitlan (Mexico). }\end{array}$ \\
\hline & I NDIAN NOTES \\
\hline
\end{tabular}




\section{A Z T E G OLDSMITHS}

Cortés describes the great market of Tenochtitlan, and the great quantity of things daily exposed for sale included jewels of gold, silver, and stones. The Anonymous Conqueror, in describing the great market, states that it was held every fifth day, and that "on one side of the plaza are those who sell gold, and adjoining are those who sell stones of various classes set in gold, in the shapes of various birds and animals."

This refers to mosaic jewels with stone and gold inlays. Cortés further informs us that Montezuma had in his house representations in gold, silver, stones, or feathers, of every object of his domain, beautifully executed; and there is also a statement that in the collection of Nezahualcoyotl, king of Texcoco, were the representations in stone mosaic-work and gold of every bird, fish, or animal which could not be obtained alive. ${ }^{52}$

We are not lacking in statements regarding the mechanical processes used in the manufacture of gold-leaf, and the modeling and casting of jewels and other objects of both gold and silver.

\section{A ND MONOGRAPHS}




\begin{tabular}{|c|c|}
\hline 120 & G OL D M I TH'S A R T \\
\hline & $\begin{array}{l}\text { In the Codex Mendoza }{ }^{53} \text { is an illustration } \\
\text { of a goldsmith at work. This is shown on } \\
\text { pl. II, B. The crucible appears to be a clay } \\
\text { tripod vessel, from which flames are rising, } \\
\text { and against the flames is the hieroglyph } \\
\text { for gold. Other hieroglyphs for gold, taken } \\
\text { from various sources, are given in our figs. } \\
3 \text { to } 6 . \text { The Indian, seated on a mat, is } \\
\text { teaching a child; he has in the right hand } \\
\text { a blowpipe, which tapers outwardly, as if } \\
\text { Fig. 3. } \\
\text { to diffuse the blast for obtaining greater } \\
\text { ignition of the charcoal to intensify the heat. } \\
\text { The implement held in the left hand may } \\
\text { perhaps represent tongs. Large copper } \\
\text { implements, usually regarded as tweezers, } \\
\text { have been found, and may have been em- } \\
\text { ployed for this purpose. } \\
\text { We have another representation of the } \\
\text { goldsmith at work in the Mappe Tlotzin, }\end{array}$ \\
\hline & I N I A N NOTES \\
\hline
\end{tabular}



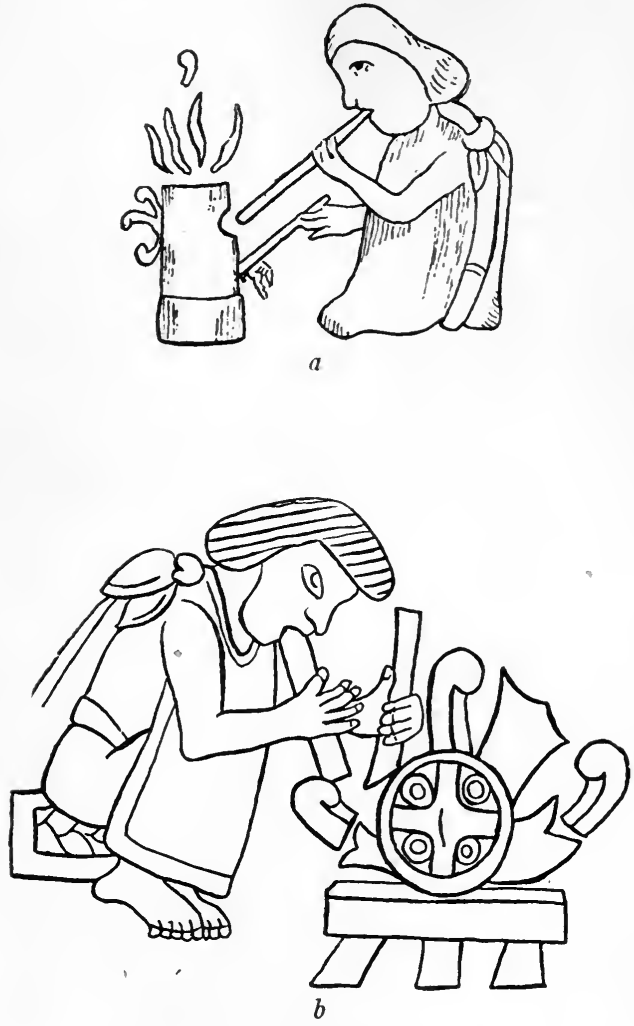

MEXICAN GOLDSMITHS AT WORK (After Mexican Codices) 

given on pl. II, A. The furnace-is not quite cylindrical, for its diameter is smaller at the top than at the base. There are two openings in the body of the crucible, just below the rim, which permitted the blast of either one or two blowpipes to be directed upon the charcoal in the crucible. Another hole near the bottom admitted air. This vessel is probably of clay, and it rests on a stand. The artisan appears to be stirring the contents of the crucible with a rod held in the left hand, while he blows the fire through a tube held in the right hand.

Motolinia, one of our best authorities, states that-

"In order to be good silversmiths or plate workers, they lacked only tools, which they did not have, but with one stone over another they make a plain cup and a plate. Moreover, to smelt a piece and make a cast, they took preference over the silversmiths oi Spain, inasmuch as they could cast a bird with movable tongue, head, and wings and cast a monkey or other monster with movable head, tongue, feet, and hands, and in the hand put a toy so that it appeared to dance with it; and even more, they take out a piece, one-half of gold and one-half of silver, and cast a fish with all its scales, the one of gold and the other of silver." 55

\section{A N D MONOGRAPHS}




\begin{tabular}{|c|c|}
\hline 122 & GOLDSMITH'S ART \\
\hline & $\begin{array}{l}\text { Motolinia also states that although the } \\
\text { ancient Mexicans were not good metal } \\
\text { beaters, a silversmith from Spain tried to } \\
\text { conceal his art fro n the Indians, telling } \\
\text { them that it took a'l apprentice eight years } \\
\text { to learn the trade, but by watching him } \\
\text { work and counting the number of blows, } \\
\text { and how he turned and revolved the mold, } \\
\text { etc., within less than a year they were able } \\
\text { to work in the same manner. } \\
\text { Notwithstanding this statement that the } \\
\text { Mexican natives were not good beaters of } \\
\text { gold, we have abundant evidence that they } \\
\text { were able to work the metal into very thin } \\
\text { gold-leaf, as in recent years pottery vessels } \\
\text { and beads have been found decorated with } \\
\text { such. Furthermore, they gilded their cere- } \\
\text { monial atlatls, }{ }^{96} \text { several of which are now in } \\
\text { European museums, probably being part } \\
\text { of the objects sent over to Spain by Cortes } \\
\text { himself. } \\
\text { That the Aztecs did not immediately lose } \\
\text { their skill in the art of casting and hammer- } \\
\text { ing gold after their subjugation by the } \\
\text { Spaniards, is shown by the statement of } \\
\text { Torquemada, }{ }^{57} \text { who, writing in } 1608 \text {, relates }\end{array}$ \\
\hline & I N I A N NOTES \\
\hline
\end{tabular}




\begin{tabular}{|c|c|}
\hline AZTEC GOLDSMITHS & 123 \\
\hline $\begin{array}{l}\text { that, being in need of some gold buttons, } \\
\text { an Aztec working in the manner of his } \\
\text { ancestors made the buttons in the shape } \\
\text { of small gourds, so perfectly imitated as to } \\
\text { excite great admiration. Sahagun, in his } \\
\text { great work on "The Things of New Spain," } \\
\text { in treating of the artisans who worked } \\
\text { gold, writes: }\end{array}$ & \\
\hline $\begin{array}{l}\text { "In this chapter commences a treatise of } \\
\text { the artisans who worked gold and silver. They } \\
\text { are of two kinds. Some of them are called } \\
\text { beaters. These worked gold with the hammer, } \\
\text { pounding with hammers to make it thin like } \\
\text { paper. Others are called tlatlaliani, that is, } \\
\text { those who fuse the gold, or anything else in it, } \\
\text { or silver. These are the true artisans, who are } \\
\text { also called by another name, Tulteca, but they } \\
\text { are divided into two classes, because each one } \\
\text { works the gold according to his own manner." }\end{array}$ & \\
\hline $\begin{array}{l}\text { The circumstantial and extended account } \\
\text { of the methods employed by the Aztecs in } \\
\text { working gold, furnished us by Father } \\
\text { Sahagun, is unfortunately not included in } \\
\text { the abridged form of the work published by } \\
\text { Bustamante and Lord Kingsborough. The } \\
\text { original work, of greater length, written in } \\
\text { the Nahuatl language and accompanied }\end{array}$ & \\
\hline A ND MONOGRAPHS & \\
\hline
\end{tabular}




\section{GOLDSMITH'S ART}

with a large number of paintings, has never been published. Part of the manuscript is in Madrid, and the other part in Florence. The Mexican scholar, the late Francisco del Paso y Troncoso, was engaged for more than twenty years in the translation into Spanish and the annotation of this work of Sahagun. In 1912 the writer was shown by Sr Troncoso, in Madrid, the first two printed volumes of his edition, and was informed that it would be completed in seven or eight volumes, the third and fourth volumes being at that time in press. Professor Seler has published several chapters of the Nahuatl text with a translation into French. ${ }^{59}$ One of these is that treating in extenso of the goldsmiths of the valley of Mexico, probably of those who lived in Atzcapotzalco. It should have formed chapter xvi, ninth book, of the Spanish text published by Bustamante, but Sahagun, in preparing this abridged Spanish version, omitted it, simply saying:

"The contents of this chapter is not of much importance, either in connection with the Faith, nor does it bear on morality, because it

\section{N D I A N N T E S}




\section{A Z T E C GOLDSM T T S}

is solely a geometric (mechanical) profession. If one wishes to learn about it, he has only to question the artisans who work at this trade, who are to be found everywhere." 60

Bustamante justly laments the omission of this section, as being one about which we would like most to learn. He scores the Spaniards for allowing the Indians to lose the knowledge of their ancient crafts, and states that it is a mortal blow to the fine arts.

From this chapter we learn of the main processes of their art. Successful experiments along this line have been made by Francisco León, the brother of Dr Nicolas León, which have been published by the latter. ${ }^{61}$

Sahagun's account is so important that we append the Nahuatl text, with a translation of the French rendering by Seler.

\section{Chapter I}

1. "Nican motcneua yn iuhqui yc tlachichiua yn ychoantin teocuitlapitzque, yn tecultica, yoan vicocuitlatica, tlatlalia, tlacuilona, ynic, quipitza teocuitlatl yn coztic yoan yn iztac."

1. Here is treated the manner of working of the goldsmiths, who make a mold by means of

\section{A N D M O NOGRAPH S}




\begin{tabular}{|c|c|}
\hline 126 & GOL D S M T H'S A R T \\
\hline & 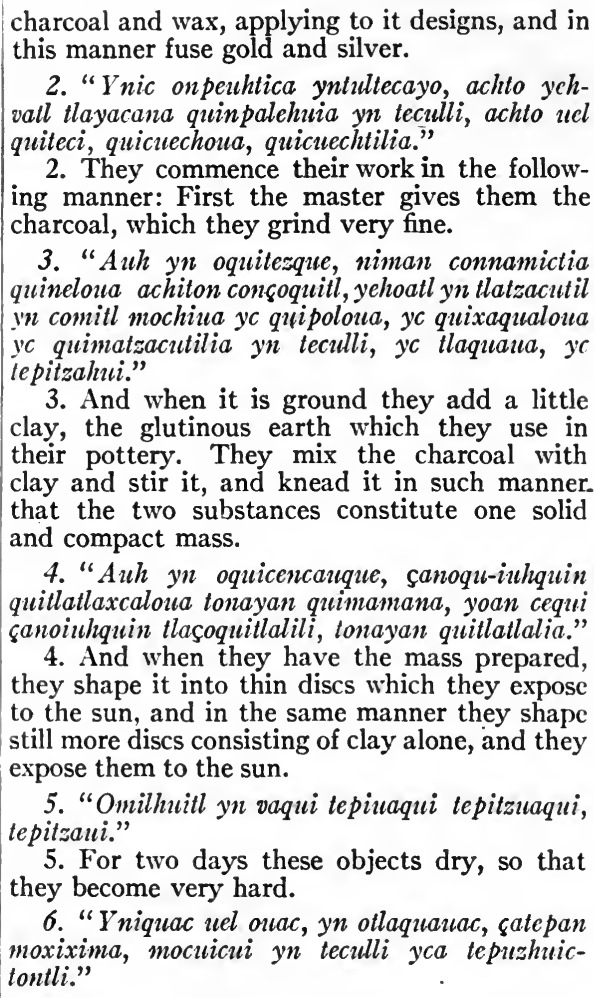 \\
\hline & I N I A N NOTES \\
\hline
\end{tabular}




\section{A ZTEC GOLDSMITHS}

6. When the charcoal is well dried and very hard, it is cut, then it is carved by means of a little scraper of copper.

7. "Can mixnenpenaltia, moyolcapenaltia, yn mocuicui, ca mixtiuia moyolhuia, yniqu-ipan quiçuz yn çą̧o tlehin mochiuaz."

7. That which is cut shall resemble the original and must have life, for whatever may be the object that is intended to be manufactured, the form resulting from it must resemble the original and have life.

8. "In ą̧o cuextccatl, aço toueyo, yacahuicole, yacacoyunqui, yxtlan mina, motlaqu-icuilo ytrconatica; niman yuh motlatlalia yn teculli, y'nic moxixima ynic motlatlamachia."

8 . For erample, if they wish to manufacture

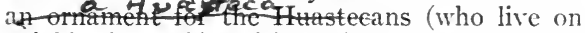
neighboring soil), with their great nose arch, the hole piercing the partition of the nasal passages, where an arrow is inserted which goes across the face, and having the body tattooed, decorated with figures of a serpent by meins of obsidian neetle points, they fashion the charcoal paste in this manner, cut it out and cover it with the above mentioned designs.

9. "Ytech mana yn catleuatl motlaychyeculhuia, yn quenami yyeliz, ytlachieliz motlaliz."

9. They are very careful to consider what animal they wish to imitate; how its being and its aspect must be represented.

10. "In aço a votl, niman yuh motlalia y'n teculli, ynicacallo ynic moliniticz, yticpa nalitstica, ynitzontecon molinitica, yniquech, yoan ynima, yniuhqui yc mamaçountica."

\section{A ND MONOGRAPHS}

1. N. 11. -2 


\begin{tabular}{|c|c|}
\hline 128 & GOLDSMITH'S A RT \\
\hline & $\begin{array}{l}\text { 10. For, example, if they wish to imitate a } \\
\text { turtle, they fashion the charcoal in this form. } \\
\text { They make its shell, in which it can move, from } \\
\text { the bottom of which its head looks out and from } \\
\text { which its four feet extend and move about. } \\
\text { 11. "Yn anoço tototl ypan quiçaz teocuitlatl, } \\
\text { niman yuh mocuicui, yuh moxima yn teculli, } \\
\text { ynic mihuiyotia matlapaltia mocuitlapiltia mocx- } \\
\text { itia.". } \\
\text { 11. Or if they desire to give the shape of a } \\
\text { bird, the charcoal is cut and carved in this man- } \\
\text { ner with its bird plumes, its wings, its tail and } \\
\text { its feet. } \\
\text { 12. "Anoco michin yn mochiuaz, niman yuh } \\
\text { moxima yn teculli, ynic moxinicayotia, yoan } \\
\text { motlallalilia ynipatlania yynmotlan, yoan yni- } \\
\text { uhquac ycuillapil maxaltic." } \\
\text { 12. Or if they might wish to make a fish, } \\
\text { they carve out the charcoal in the form of a } \\
\text { fish covered with scales, and they mold its } \\
\text { fins, its sides and its forked tail. } \\
\text { 13. "Anoço chacalin, anoço cuetzpalin mo- } \\
\text { chiuh motlalia ynima." } \\
\text { 13. Or when they desire to make a crab or a } \\
\text { lizard, its feet are molded. } \\
\text { 14. "Ynic moxima teculli, yn ça̧̧o catleuatl } \\
\text { motlaycyecalhuia yoyoli. } \\
14 \text {. Whatever may be the animal which they } \\
\text { wish to imitate, it is carved out of charcoal in } \\
\text { this manner. } \\
\text { 15. Anoço teocuitlacoscatl yccahuiz, chayau- } \\
\text { acayo, tencoyllo tlatlatlamachilli, tlaxochiycui- } \\
\text { lolli." }\end{array}$ \\
\hline & I N I A N NOTES \\
\hline
\end{tabular}




\section{A Z TEC GOLDSM I THS}

15. Or if they wish to manufacture a gold collar besprinkled with precious stones, provided with bells on the lower edge and decorated with reliefs and with designs of flowers.

16. "Yniquac yc omocencauh teculli, yn omicuilo, yn omocuicuic, niman mopauaşi yn xicocuitlatl, moneloua, yztec copalli yc uellaquaua."

16. When the charcoal is prepared in this manner, and is provided with designs and is carved out, they boil the wax, and they mix it with white copal, by which it becomes very compact.

17. "Catepan moyectia motzetzeloua, ynic ue uetzi ynitlayello, ytlalo, y̧̧oquiyo xicocuitlatl."

17. Then they clarify it by filtration, in order that the impurities of the wax, the dirt and the clay which are mixed with it, may be well settled out.

18. "Auh yniquac omocencauh xicocuitlatll çatepan ytztapaltepan mocanaua, momililoua yca quammaytl, mimiltic."

18. When the wax is prepared, they thin it out on a flat stone, and flatten it by means of a cylinder of wood which they roll over it by hand.

19. "Ye yn uel xipetztic tetl yn texixipetalli ypan mocanaua, momimiloua."

19. They thin it out and flatten it on a very smooth stone.

20. "Yniquac ouel mocanauh yn çayuhqui tocapeyotl, yn aoccan chicotilauac, niman ytech motlalia yn teculli, yc on mixquimilona."

\section{A N D M NOGRAPHS}




\section{GOL DSMITH'S ART}

20. When the wax is very thin, like the web of a spider, and is not more thick in any one place, they apply it on the charcoal, (which has been carved out) and they cover the charcoal with wax.

21. "Auh amo çan ilihuiz ynitech motlalia çan ihuian achitoton mocotoniuh motectiuh ynic çanipan oncacalaqui."

21. And they do not do it heedlessly, but they carefully cut a small piece nearly corresponding to the dimensions of the object.

22. "Yueuetzian onmotlaça, ycácalaquian, yaaquian onmaquia, yn oncan omocuicuic teculli."

22. They coat over the salient parts and cover the hollows, especially where the charcoal has been carved.

23. "Tepiton quauhtontli ynic on mogalotiuh."

23. The wax is applied (to the charcoal) by means of a bit of wood.

24. "Auh yniquac omocencauh yn ye nohuian ytech omotlali yn xicocuitlatl, çatepan teculatl yxco moteca yn ricocuitlatl."

24. And when all is done in this manner, and the wax is put on all parts of the charcoal, they put pulverized charcoal on the surface of the wax.

25. "Uel moteci, mocucchtilia yn teculatl, achi yxtilauac ynixco onmoteca xicocuitlatl."

25. They grind the charcoal powder well, and they spread a rather thick layer on the surface of the wax.

26. "Auh yn yc yuhqui yn omocencauh oc-

\section{N D I N NOTES}




\section{AZTEC GOLDSMITHS}

cepa ytech motlalia tlape pecholoni yc moquimiloua mocentlapachoua."

26. And when all is prepared thus, they put on it another covering; the shell which encompasses the mold and encloses it all over.

27. "In oyecauh tlachinalli ynic mocopinaz teocuitlatl."

27. The making of the shell is the last of the processes intended to give the gold its form.

28. "Inihin tlapepecholoni, çanno teculli, no tlanelolli tlaltzacutli, amo cuechtic, çan papay'artic."

28. This shell is also made of charcoal, mixed with clay, but the charcoal is not finely ground, only roughly crushed.

29. "Yniquac yc omopepecho ynic omocenquimilo tlacopinaloni, ocno omilhuitl yn uqqui."

29. When the mold is enclosed and encompassed by the shell, they let it dry for two more days.

30. "A uh çatepan ytech motlalia ytoca anillotl, çanno xicocuitlatl."

30. Then they put on the spout, which is made of wax also, (encompassed by a shell).

31. "Yehoatl ynipiazyo mochinaya tecuitlatl ynic oncan calaqui yniquac oatix."

31. The latter serves as a drainage canal, by which the melted gold enters.

32. "Auh yoan occepa ypan momana motlalia ytoca tlacaxxotl, çanno teculli yn tlachinalli tlacomololli."

32. And then they place the crucible on the

\section{A N D MONOGRAPHS}




\begin{tabular}{|c|c|}
\hline 132 & GOLD S M I TH'S.AR T \\
\hline . & $\begin{array}{l}\text { ground, which is also made of charcoal (and of } \\
\text { clay) and which is hollow. } \\
\text { 33. "Niman yuhmati motlalia yn teculli." } \\
\text { 33. In like manner they set out the (mold, } \\
\text { with its shell, both made of) charcoal. } \\
\text { 34. "Oncan mocaxxotia matilia yn teocuitlatl, } \\
\text { ynic catepan calaqui ylech anillotl, ynic oncan } \\
\text { mopiazyotia, ynic on totoca tlaticpa on noquihui." } \\
\text { 34. It is there where the gold is melted, in } \\
\text { order then to enter the spout, and being con- } \\
\text { ducted by the latter, to flow below and run out. } \\
\text { 35. "Auh yniquac omopitz yn çaço tleyn coz- } \\
\text { catl oyecauh yn izqui tlamantli nican omoteneuh, } \\
\text { niman yc mopetlaua yca texcalli." } \\
\text { 35. And when it is melted and run into the } \\
\text { mold, and when, for example, they have manu- } \\
\text { factured a collar, or one of the various objects } \\
\text { mentioned in this chapter, they polish it by } \\
\text { means of a stone. } \\
\text { 36. "Auh yn omopetlauh yenocuele motlalxo- } \\
\text { cohuia." } \\
\text { 36. And when it is polished, they put it in } \\
\text { an alum bath. } \\
\text { 37. "Moteci yn tlalxocotl yc maaltia yc mo- } \\
\text { mamatiloua yn tcocuitlatl yn omopitz.". } \\
\text { 37. They grind the alum, and they soak in } \\
\text { it and wash with it the gold jewel which they } \\
\text { have cast. } \\
\text { 38. "Oppa yn tleco calaqui ypan mototonia." } \\
\text { 38. A second time they put it in the fire, and } \\
\text { heat it inside. } \\
\text { 39. "Auh yn oualquiz occeppa yenocuele yce }\end{array}$ \\
\hline & I N I A N NOTES \\
\hline
\end{tabular}




\section{A ZTEC GOLDSMITHS}

maaltia yc momamatiloua ytoca teocuitlapatli, çuniuhqui tlacoztli moncloua achiton izlatl yc mocencana yc cenca coztic mochiua yn teocuitlatl."

39. And when it comes out of the fire, they bathe it a second time, and smear it with ointment of gold, which is composed of muddy earth mixed with a little salt, by means of which the gold becomes beautiful and very yellow.

40. "Auh çatepan yc mopetlaua motecpahuia yc uel mocencaua, ynic yequene uellanextia pepellaca motona meyotia."

40. And thus they rub and polish and make beautiful the jewel, so that it becomes very brilliant, resplendent, and radiant.

41. "Mitoua yye uecauh çan oc yeh yn coztic tcocuitlatl nenca yn mahuiltiaya, yn quipitzaya tecuitlanıaque yn quichinaya cozcatl yoan quitzotzonaya yn quicananaya teocuitlatzotzonque ynitech monequia tlahuiztli.'

41. They narrate that formerly there was only the gold; that it was only the gold which they used and that the goldsmiths poured it in the mold and formed of it collars, and that the smiths hammered it, and flattened it and made of it the embossed work which served for all kinds of military devices of which there was need.

42. "Ayatle catca yn istac teocuitlatl, tel onnenca çanoc canin neçia vel motlaçotlaya."

42. Silver did not exist, except in the places where it was found (like natural silver), and it was greatly valued.

43. "Auh yn axcan yenocuele çammache yn

\section{A N D MONOGR A P H S}


istuc teocuitlatl quinequi, yn cosrix yc uel motlacolla."

43. But now they use only silver (for trinkets), for the gold is too valuable.

H. "In yehoantin tcocuitlanuque, yn tlepitzque yoan yn tlatzotsonque, yn acxun yc tlachichim no quinequi yn chichitic tepustli."

44. Now, the goldworkers, the founders, and the smiths, if they manufacture some jewel. employ copper for it as well.

45. "Tel can tlayxyeyecoll. i thatamachinalli ynipan quitlaça ystac tcocuitlatl, yc çalia yc chictia."

45. But they add to the silver only a moderate and measured quantity, which alloys itself with it.

46. "A uh yntla çan mixcahui mopitza yzlac tcocuitlatl, çan tlaila paca tzatzayani yn tlachinalli."

46. And if the gold is cast without alloying, the work is broken up.

47. "A mo uel nohuianpa monanamiqui mocacamapiqui v'n oncan çaçaliuhtiuh y'c tlutlatlamachilli."

47. And the reliefs which are welded on it are not attached on all sides nor without cracks.

48. "Auh yn yehoantin teocuitlatsotzonque yn ye uecamh çan quixcahtuiay'a yn tcocuitlatl quitzolsonay a."

48. Likewise the ancient goldsmiths neither worked nor hammered out any other metal than gold.

49. "Quitsotsonaya quitealaua quipetlaua yoan quiteycuilona tlilanpa."

\section{N D I A N NOTES}


49. After they had beaten the gold, they polished it and furbished it and put designs on it, conforming to the tracings of the drawing.

50. "Achtopa quimicuilhuiaya yn amanteca."

50. In the first place they asked the featherworkers to trace the design for them.

51. "Auh çatcpan yehoantin quiteycuilouaya yca tecpatl."

51. Then they themselves put on the design by means of a stone point.

52. "Quitotocatihui yn tlilantli ynic tlatecpaycuiloua."

52. In putting on the design by means of the stone point, they followed the trace.

53. "Quitotomoloua quitotomolotihui ytech cantihui yn quenami machiotl."

53. They made corrugations, keeping always to the model.

57. "Caneyo yuh tlachichina yn axcan ynic cana monequi ynilachinal."

54. In the same manner they work today, especially where one has need of their works.

55. "A乌o yhuitlacuilolli yhuitlachinalli ytech monequi quinepahuia quimottitia yn amanteca ynic quitelequi yn quexquich quinamictiuh yhuitlachinalli."

55 . And if by chance they need a piece of feather-work, they address themselves to the feather-workers, who cut out all kinds of work in feathers which are presented to them. que."

56. "In axcan ye yc tlachichiua teocuitlaua-

\section{A N D MONOGRAPH S}




\begin{tabular}{|c|c|}
\hline 136 & GOL D M I TH's A R T \\
\hline • & 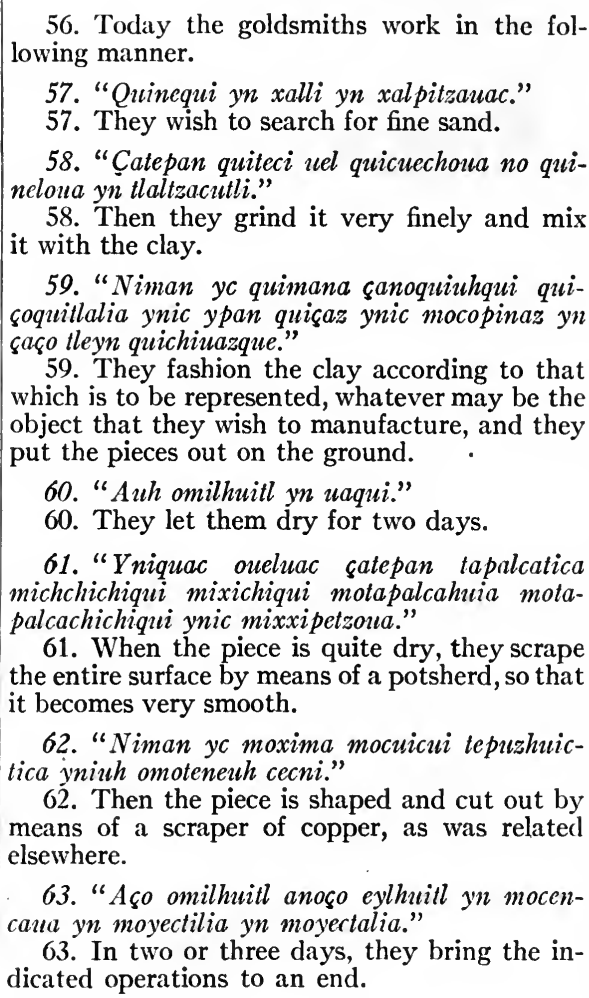 \\
\hline & I N I A N NOTES \\
\hline
\end{tabular}




\begin{tabular}{|c|c|}
\hline A ZTEC GOLDSMITHS & 137 \\
\hline $\begin{array}{l}\text { 64. "Yniquac omocencauh, niman tecullatl } \\
\text { yxco moteca yoan tzaculli yc onixxipetzihui." } \\
64 \text {. When all is ready, they spill some pul- } \\
\text { verized charcoal on the surface, producing a } \\
\text { smooth surface by means of the paste. }\end{array}$ & \\
\hline $\begin{array}{l}\text { 65. "Yc niman mopauachi yn xicocuitlatl mone- } \\
\text { loua yn iztac copalli yniuh omoteneuh." } \\
65 \text {. They boil the wax, and they add to it } \\
\text { the white copal, as has been described before. }\end{array}$ & \\
\hline $\begin{array}{l}\text { 66. "Yn oceuh yn omoyecti niman mocanaua } \\
\text { yzatapaltepan quammatica momimiloua yc." } \\
\text { 66. And when the wax has become cold and } \\
\text { when it has become clarified, they thin it out } \\
\text { and roll it out on a flat stone by means of a } \\
\text { wooden roller. }\end{array}$ & \\
\hline $\begin{array}{l}\text { 67. "Niman ytech motlalia ytech moçaloua yn } \\
\text { tlatlalilli coquitl ynic mocopinaz teocuitlatl yn } \\
\text { caço tleyn mochinaz." } \\
\text { 67. Then they apply the wax on the surface } \\
\text { of the clay mold which is to be cast in gold, } \\
\text { whatever may be the object that they wish to } \\
\text { manufacture, and they bind it to it. }\end{array}$ & \\
\hline $\begin{array}{l}\text { 68. "Yn aço jarro anoço tlapopochhuiloni yn } \\
\text { quitocayotia perfomador." } \\
\text { 68. It may be that they wish to make a jug } \\
\text { or a scent box that is called a perfomador. }\end{array}$ & \\
\hline $\begin{array}{l}\text { 69. "Ye micuilona yc mollatlamachia yn } \\
\text { qualli "lacuilolli." } \\
\text { 69. They furnish it with beautiful designs } \\
\text { (worked in wax). }\end{array}$ & \\
\hline $\begin{array}{l}\text { 70. "Occenca ye quimati yn xicucuitlatl oc-; } \\
\text { cenca ye tlahuica ynic tlacuilolo ynic tollecatiua." }\end{array}$ & \\
\hline AND MONOGRAPHS & \\
\hline
\end{tabular}




\begin{tabular}{|c|c|}
\hline 138 & GOLDSMITH'S ART \\
\hline & 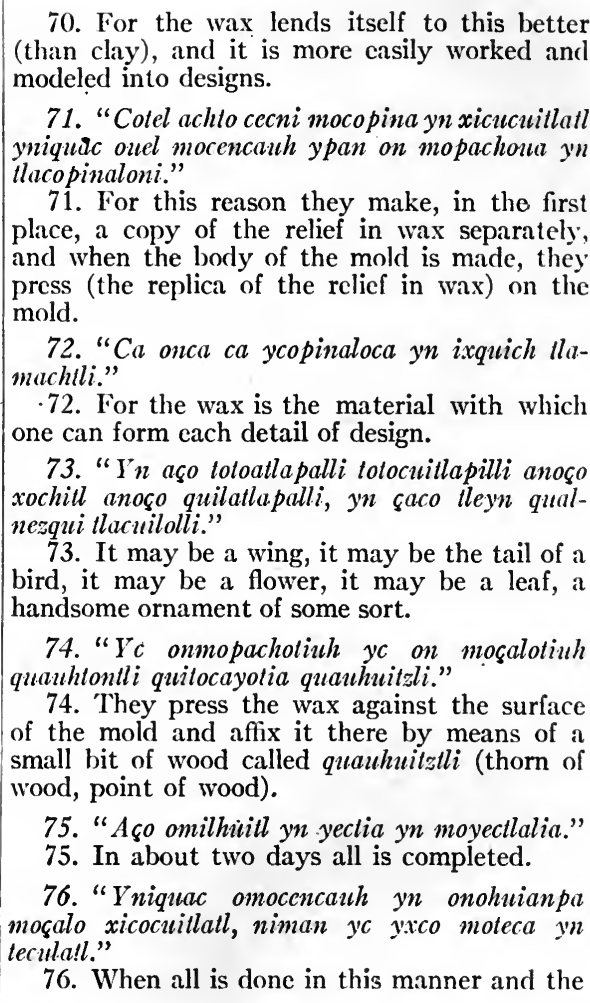 \\
\hline & I N D I A N NOTES \\
\hline
\end{tabular}




\section{A Z T E C GOLD S I TH S}

wax has been affixed on the entire surface of the mold, they coat it over with pulverized charcoal.

77. "Yn ouac yenocuele ytech motlalia $y n$ llapepecholoni yn çan papayaxtic teculli ynic mocenquimiloua yn tlacopinaloni."

77. After it has become dry, they put the shell on it, made of charcoal coarsely crushed (mixed with clay), and enclose the mold with it.

78. "Aço omilhuitl yn uaqui."

78. For about two days, they let it dry.

79. "Niman yc ytech onmotlalia yn xicocuitlall ynitoca anillotl mimiltic."

79. Then they put on it the cylinder of wax, called anillotl (spout).

So. "Achtopa momimilona, yehoatl ypiazyo mochina yn teocuitlatl ynic oncan calaqui."

80. At first they roll it (to give it a cylindrical form); it serves as a drainage canal by which the gold enters.

81. "Auh yn omotlali anillotl, yenocuele ypan momamana yn tlacaxxoll yn oncan antieg teocuitlatl."

81. And when the spout is so placed, they put the crucible in which the gold will be melted, out on the ground.

82. "Yniquac ye yuhqui yn omochi omocencauh, niman yc tleco motlalia mocentotonia."

82. After everything is done in this manner they put everything in the fire, and they heat it.

83. "Oncan quiça oncan tlatla yn xicocuitlal yn tlatic omotlalica."

\section{A N D MONOGR A P H S}




\begin{tabular}{|c|c|}
\hline 140 & GOLD SM ITH'S A R T \\
\hline & 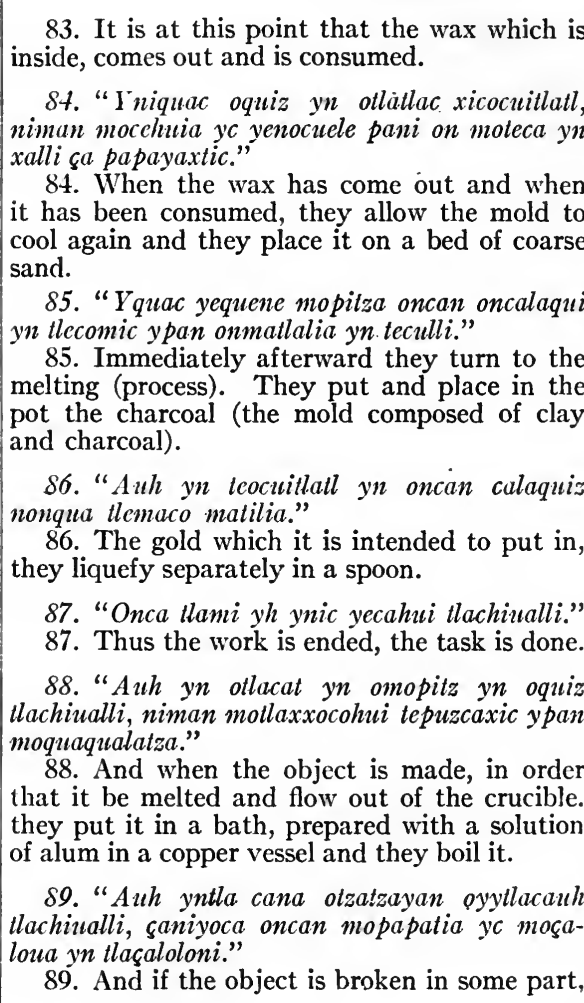 \\
\hline & I N I A N NOTES \\
\hline
\end{tabular}




\section{A Z T E C GOLDSMITHS}

or if it is cracked, they mend separately the damaged sections and they solder on the broken part.

90. "Auh çatepan yc michiqui yn timatepuztli yc mopetlaua."

90. Then they scrape it and polish it by means of an instrument of copper.

91. "Occeppa tlalxocotitlan calaqui motlaxxocohuia."

91. And they immerse it in another alum bath.

92. "Yc çatepan mocencana motecpahuia ynic uel mopetlaua."

92. Finally they polish it and furbish it so that it becomes very brilliant.

Seler summarizes the information contained in this chapter as follows:

"The contents of the preceding chapter show that the ancient Mexicans understood and exercised the two separate branches of the art of gold-working, that is to say, smithing and founding. They beat the metal by means of a stone and embossed it by means of a pointed instrument of stone. These objects manufactured by the smiths served principally for military devices worked in feathers.

"As to founding, it is necessary to distinguish between the two methods of working, an ancient one (antedating the Conquest), and a modern one (of the period of Spanish influence). The

\section{A N D MONOGRAPHS}




\begin{tabular}{|c|c|}
\hline 142 & GOLDSM ITH'S ART \\
\hline & $\begin{array}{l}\text { former was more artistic and of superior skill; } \\
\text { the latter was coarser. The ancient people } \\
\text { made the mold from a mixture of clay and of } \\
\text { charcoal, finely ground, which they let dry and } \\
\text { harden in the sun. It was a material which lent } \\
\text { itself admirably to cutting and sculpture. But } \\
\text { the ancient workers cut and sculptured all the } \\
\text { details of the object to be cast, directly in this } \\
\text { material, and before putting the shell on it, they } \\
\text { covered this mold, carved in charcoal, with a a } \\
\text { thin layer of wax, which they made follow all } \\
\text { reliefs and hollows. They cut out and sculp- } \\
\text { tured the charcoal by means of a copper instru- } \\
\text { ment. } \\
\text { "The modern workers constructed the mold } \\
\text { of a mixture of clay and sand, which they too } \\
\text { let dry in the sun. But it seems that they } \\
\text { worked in this material only on general forms } \\
\text { for the object to be cast, and that they con- } \\
\text { tented themselves with executing the detailed } \\
\text { ornamentation in wax, with which they covered } \\
\text { the mold. They covered the object with } \\
\text { thin, smooth layer of pulverized charcoal. The } \\
\text { shell itself was made of a mixture of clay and of } \\
\text { charcoal coarsely crushed. A cylinder of wax } \\
\text { (enclosed in the shell) served as the drainage } \\
\text { canal. By heating the mold in the fire they } \\
\text { made the wax run out. Then they placed the } \\
\text { mold in a vessel, and poured in the gold, which } \\
\text { they melted in a spoon (of clay mixed with } \\
\text { charcoal?). The jewel being cast, they dipped } \\
\text { the object in an alum bath, then they rubbed it } \\
\text { with a mixture of muddy earth and salt, and } \\
\text { polished it." }\end{array}$ \\
\hline & I N D I N NOTES \\
\hline
\end{tabular}




\section{OAXACA JEWELS}

GOLD JEWELS FROM THE STATE OF OAXACA

According to Bernal Díaz, when the southern part of Mexico, especially that now comprised by the state of Oaxaca, was first settled by the Spaniards, Figueroa, an officer among the conquerors, was sent by Cortés to Quaxaca (Oaxaca) to subdue the Zapotecs. Instead of so doing,-

"he determined to undertake the excavation of the graves in the burial places of the caciques of those provinces, for he found in them a great quantity of golden jewels which it was the custom in olden days to bury with the chieftains of those pueblos, and he attained such dexterity that he took out from them over five thousand pesos de oro, in addition to other jewels from the [the text reads, dos, 'two'] towns, so he determined to abandon the conquest."

In no other part of Mexico have been found so many objects of gold as in Oaxaca. All of these objects have been discovered accidentally by the Indians, who have encountered tombs while digging wells, or in making excavations to secure earth for molding adobe bricks, or when plowing; or they have been disclosed by heavy

\section{A N D MONOG A P H S}




\begin{tabular}{|l|l|}
\hline 144 & \multicolumn{1}{|c|}{ G O L D S M I T H ' S A R T } \\
\hline $\begin{array}{l}\text { showers during the rainy season. Unfor- } \\
\text { tunately the greater part of these objects } \\
\text { has gone to the melting-pot. } \\
\text { During the extended operations of the } \\
\text { Loubat Expedition in the winters of 1898 } \\
\text { to 1902, in the valley of Oaxaca and the } \\
\text { ruins of Mitla, not a single specimen of } \\
\text { gold was found by the writer. } \\
\text { For many years the late Dr Fernando } \\
\text { Sologuren, of the city of Oaxaca, was } \\
\text { active in making a collection of Zapotecan } \\
\text { and Mixtecan antiquities, which became } \\
\text { the most valuable private collection in } \\
\text { Mexico, and was later purchased by the } \\
\text { National Museum of Mexico. During } \\
\text { repeated trips to southern Mexico it was } \\
\text { the writer's privilege to make studies of } \\
\text { the objects in the collection, and to take } \\
\text { numerous photographs of the more impor- } \\
\text { tant pieces which it contained. } \\
\text { Only during recent years have any of } \\
\text { the numerous gold objects thus accidentally } \\
\text { discovered been preserved. In 1831, a } \\
\text { native, while tilling the ground on the } \\
\text { mountain called "Sombrerito," about half } \\
\text { a league from the town of Huajuapan, in }\end{array}$ \\
\hline \multicolumn{1}{|c|}{ I N D I A N N O T E S } \\
\hline
\end{tabular}



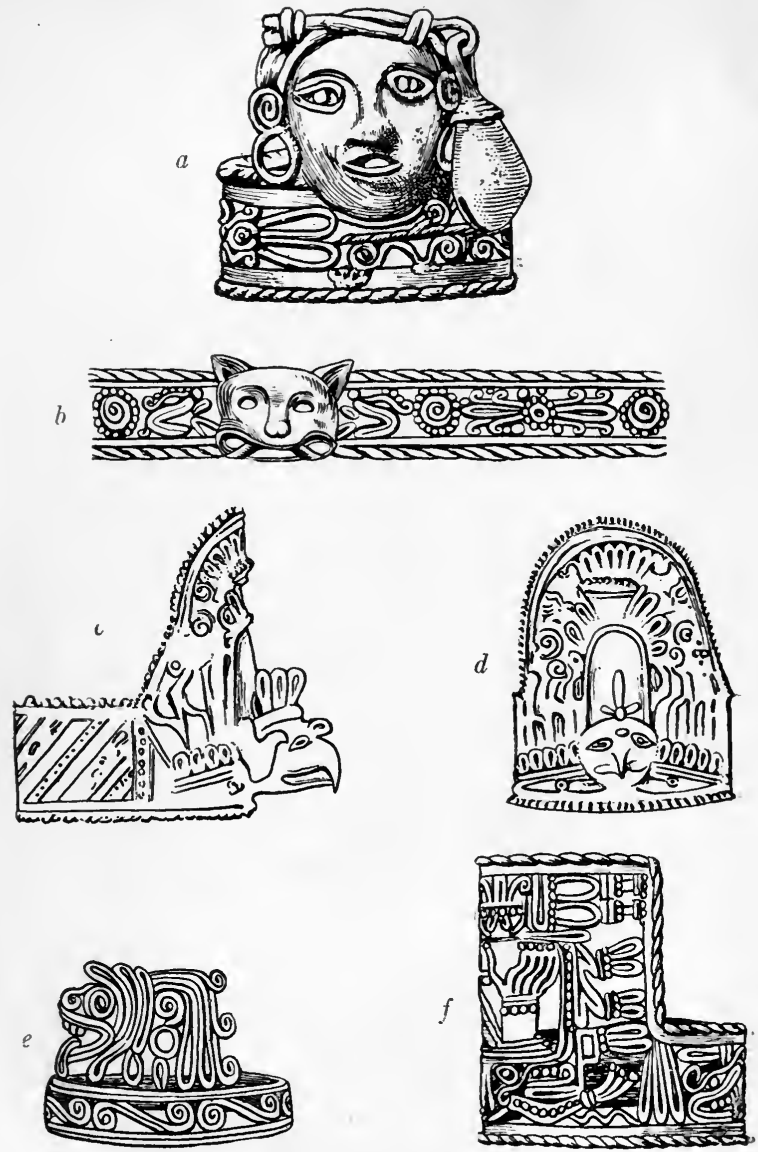

GOLD FINGS FROM THE STATE OF OAXACA 



\begin{tabular}{l} 
O A X A C A J E W E L S \\
\hline northwestern Oaxaca, discovered a tomb \\
which contained human bones, pottery, \\
gold beads, and finger-rings. Two of the \\
finger-rings were illustrated in the Museo \\
Mexicano in 1843, ${ }^{63}$ and later were illus- \\
trated and described by Peñafiel. ${ }^{64}$ The \\
largest ring was lately in the possession of \\
Mr Agustin Doorman of the City of \\
Mexico. The drawing on pl. III, a, is from \\
a photograph of the original specimen; \\
it is decorated with a human face, and from \\
above the left ear a good-sized bell hangs \\
pendent. At first glance this ring appears \\
to be made in filigree, but closer examina- \\
tion reveals that it was cast. It is 1.9 cm. \\
in diameter, and at the highest part it is \\
of the same dimension. Taken as a whole, \\
the workmanship is rather crude, and it. \\
does not compare favorably with most of \\
the gold jewels from Oaxaca. \\
The other ring is shown on pl. III, $e$, made \\
from a photograph of the original, now in \\
possession of Mr Homer E. Sargent, of \\
Chicago. It is filigree in appearance, but \\
was made by casting, and is of much finer \\
workmanship than the larger ring. Its \\
\hline A N D M O N O G R A P H S
\end{tabular}

I. N. M. -2 


\begin{tabular}{|c|c|}
\hline 146 & GOLDSMITH'S ART \\
\hline & $\begin{array}{l}\text { dimensions are } 1.8 \mathrm{~cm} \text {. in diameter and } \\
1.2 \mathrm{~cm} \text {. high. Fig. } b \text { of the same plate } \\
\text { represents a finger-ring, now in England, } \\
\text { with the design spread out; it resembles } \\
\text { the Oaxaca rings and was illustrated by } \\
\text { Joyce, }{ }^{65} \text { but with no information as to the } \\
\text { region in which it was found in Mexico. } \\
\text { It belongs to the Oaxaca type of gold orna- } \\
\text { ments, and probably came from Oaxaca. } \\
\text { Joyce states that it has the appearance of } \\
\text { gold wire, but "the reverse side shows } \\
\text { plainly that the greater portion has been } \\
\text { cast solid." } \\
\text { Among the notes of the late Dr Valentini, } \\
\text { the Mexicanist, I find certain drawings } \\
\text { made by Dr Berendt, herein reproduced } \\
\text { as pl. III, } c, d \text {. These represent the side } \\
\text { and front views, natural size, of a beautiful } \\
\text { finger-ring, with the head of an eagle pro- } \\
\text { jecting from the front. From these sketches } \\
\text { it is evident that this ring is more elaborate } \\
\text { in design and skilful in workmanship than } \\
\text { the two from Huajuapan, although pre- } \\
\text { serving the same general filigree style. } \\
\text { A note from Berendt states that the ring is } \\
\text { from the Zapoteca (Oaxaca), but the exact }\end{array}$ \\
\hline & I N 1) I A N NOTES \\
\hline
\end{tabular}




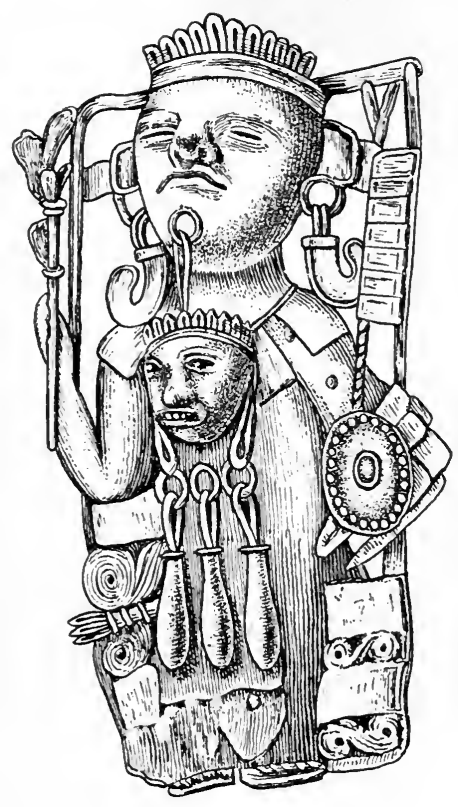

GOLD ORNAMENT FROM THE VICINITY OF TEHUANTEPEC, STATE OF OAXACA 

locality where it was discovered is not given, nor do we know where this important specimen is now preserved. The splendid ring shown in pl. $11 \mathrm{II}, f, 2 \mathrm{~cm}$. in height, has been illustrated by both Peñafiel ${ }^{66}$ and Batres. ${ }^{67}$ It is made in imitation of filigree, and was collected for the Museo Nacional of Mexico by Batres, who classes it as of Toltecan origin. Ir all its details the ring is distinctly Zapotecan in character, and it probably came from Oaxaca. Either this ring or an exact duplicate is now in the University Museum at Philadelphia.

The most notable find of gold objects reported in Mexico in modern time was made in Oaxaca in 1875. Some of the specimens discovered have been described and figured by Teobert Maler. ${ }^{68}$ At the little village of San Sebastian, near the town of Tehuantepec, some Indians, engaged in repairing a house, made an excavation in order to secure earth for making adobe bricks. They came upon an ancient tomb containing gold jewels to the value of two thousand pesos, copper objects, stone beads,

\section{AND MONOGRAPHS}




\begin{tabular}{|c|c|}
\hline 148 & GOLDSMITH'S ART \\
\hline & $\begin{array}{l}\text { shells, ornaments, and painted pottery } \\
\text { vessels. All of the gold objects, with the } \\
\text { exception of four pieces, were sold and } \\
\text { melted down. These four pieces were seen } \\
\text { by Maler, in the house of Don Gregorio } \\
\text { Toledo in Tehuantepec, and the drawings } \\
\text { published by him were made from a photo- } \\
\text { graph given him by the American Consul. } \\
\text { The most interesting piece is described by } \\
\text { Chavero }{ }^{69} \text { (see pl. Iv) as representing a dead } \\
\text { and embalmed king, with a crown of } \\
\text { feathers on the head, a shield in the left } \\
\text { hand, and a scepter in the right. Pendants } \\
\text { hang from the ears, and in the lower lip is } \\
\text { a labret, to which is attached, by a long } \\
\text { ring, a mask that hangs over the breast. } \\
\text { It is a human face, with three pendent } \\
\text { bells, two being attached to the ear-orna- } \\
\text { ments, and one placed between them. } \\
\text { It measures } 8 \frac{1}{4} \text { cm. in height. Maler states } \\
\text { that the effigy was purchased by Mr } \\
\text { Thomas Clayton, Paymaster of H. M. S. } \\
\text { Phantom, and it should be now somewhere } \\
\text { in England. The second piece, which is } \\
\text { the largest, being } 11 \frac{1}{2} \text { cm. high, is supposed } \\
\text { to represent the face of a woman (pl. v). }\end{array}$ \\
\hline & I N I A N NOTES \\
\hline
\end{tabular}




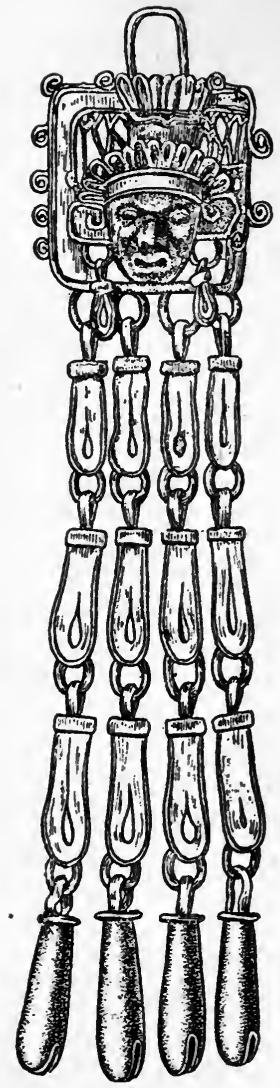

GOLD ORNAMENT FROM THE VICINITY OF TEHUANTEPEC, STATE OF OAXACA

(British Museum) 



\section{OAXACA JEWELS}

From it hang four pendants, each composed of four articulated sections, the lower one being a bell. This object has been recently illustrated by Joyce $^{70}$ and is now in the British Museum. The other two specimens are in the Ethnographical Museum in Berlin. ${ }^{71}$ The third piece (pl. vr, $b$ ), $9 \mathrm{~cm}$. high, represents an eagle's head against an openwork filigree wheel, from which hangs a small engraved plate, with four articulated pendants of two sections, the lower one of each being a bell. The fourth specimen (pl. vi, $a$ ) represents a turtle (Chavero calls it a lizard), $8 \mathrm{~cm}$. high, from which hang two articulated pendants in two sections, the lower of which is a bell, as in the other ornaments above described. This object was formerly the property of Mr J. Phillips, Consul-general of Portugal in Mexico. There can be no doubt that these jewels were buried with some distinguished priest or chief, and belong to the Zapotecan culture.

Other gold ornaments with pendent bells are shown on pl. vir. ${ }^{72}$ The largest (a) represents a human face set in the beak

A ND MONOGRAPHS 
of a bird placed on the upper edge of a thin plate. Below, attached to rings, are four flat links, each with a small ring attached, from which depend long bells. The pendants and bells are like those of the specimen shown on -pl. v. This ornament is in the Sologuren collection and was found in Oaxaca. Pl. vIr, $b$, represents, according to Batres, an ear-ornament $;^{73}$ it was collected by Batres, and is in the Museo Nacional of Mexico. Batres does not give its location, but states that it is of Toltecan origin. From its general style it would seem to be of Zapotecan derivation, though the design probably represents a conventionalized butterfly. The ornament has three bells attached by rings, but without the intervening links observed in the other specimens just described. The last piece (pl. vir, $c$ ) was collected by the writer in Oaxaca, and is now in the American Museum of Natural History; it was found with a similar object in a tomb in the valley of Oaxaca, and from the perforations through the back part of the upper section would seem to have been sewed to a garment, or

I N D IAN NOTES 

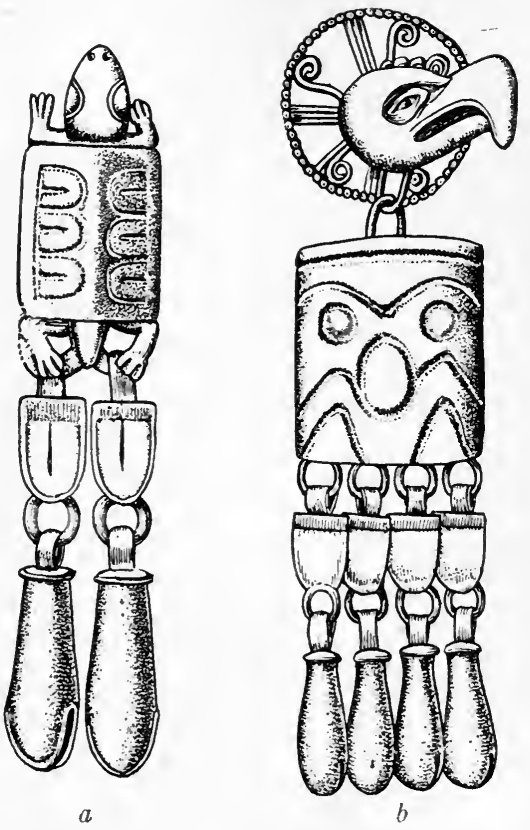

GOLD ORNAMENTS FROM THE VICINITY OF TEHUANTEPEC, STATE OF OAXACA

Ethnographical Museum of Berlin 



\section{OAXACA J E W EL S}

it may have formed an car-ornament (two having been found in the same grave) that in use was fastened by two wires or threads. The object has a bell attached by a ring. It is the last piece of this class which we have to describe.

Among the most important objects of the Sologuren collection is the beautiful broochlike jewel represented natural size in colors on pl. I. It was discovered in 1903 in a

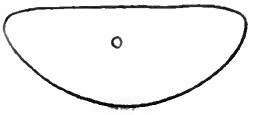

FIG. 7.

tomb in Pueblo Viejo, Yanhuitlan, in the Mixteca. The Indian from whom it was obtained stated that a skeleton was found in the burial chamber; the eyes were covered with thin gold discs, $2.8 \mathrm{~cm}$. in diameter, while over the mouth was a hemispherical, slightly concave piece of thin gold, $4.7 \mathrm{~cm}$. in length, with a perforation in the center (fig. 7). The brooch, which was found on the chest of the skeleton, represents a shield, the

\section{A N D M ONOGR A PHS}




\begin{tabular}{|c|c|}
\hline 152 & GOLDSMITH'S ART \\
\hline & $\begin{array}{l}\text { chimalli of the Mexicans, with arrows or } \\
\text { darts, and pendant bells. It is } 5.5 \mathrm{~cm} \text {. } \\
\text { in diameter, while the length of the arrows } \\
\text { or darts is } 8.3 \mathrm{~cm} \text {. The thickness of the } \\
\text { rim of the shield is } 5 \mathrm{~mm} \text {. Around the rim } \\
\text { is a scalloped decoration of gold wire. } \\
\text { Attached to the lower part of the shield } \\
\text { are eleven long, slender bells, averaging } \\
2.3 \mathrm{~cm} \text {. in length. In the illustration } \\
\text { eleven bells are shown, but there are places } \\
\text { for the attachment of two others on the } \\
\text { rear part, which are not shown in the } \\
\text { illustration. The missing bells were re- } \\
\text { moved by the Indian who found the jewel. } \\
\text { The center of the shield represents a } \\
\text { well-known Mexican hieroglyph, surrounded } \\
\text { by a mosaic of turquoise. The pieces } \\
\text { forming this mosaic were unfortunately } \\
\text { loosened and displaced by the Indian, with } \\
\text { the exception of one piece, but were fitted } \\
\text { together after the purchase of the shield } \\
\text { by Sologuren, as shown in the plate. The } \\
\text { four arrows, or darts, cross the back of the } \\
\text { shield vertically, the fore and rear shafts } \\
\text { projecting from each side. The hafting of } \\
\text { the points with wire to the foreshafts, and }\end{array}$ \\
\hline & I N I A N NOTES \\
\hline
\end{tabular}



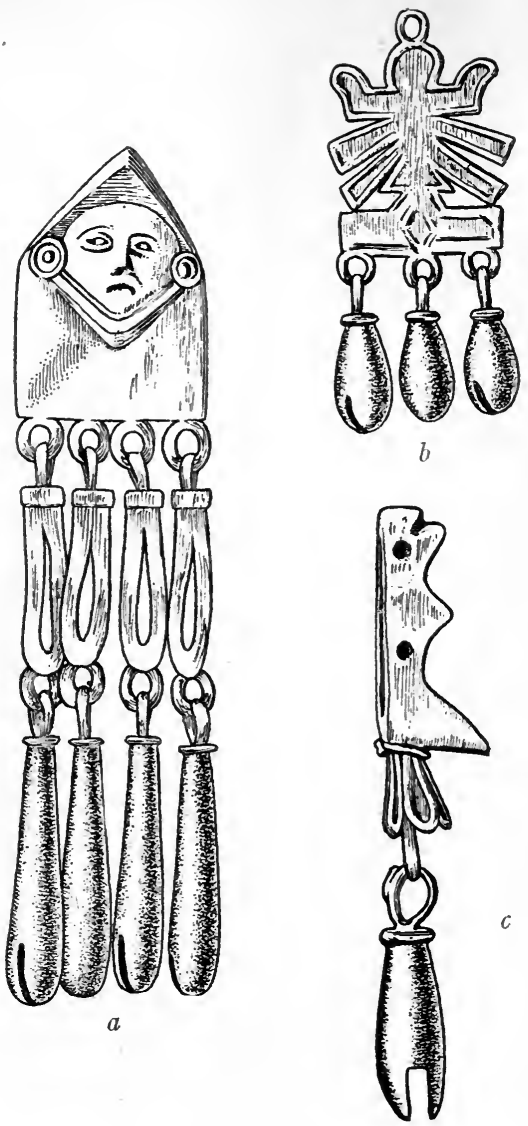

GOLD ORNAMENTS FROM THE STATE OF OAXACA 

the feathering near the nock of the shaft, are clearly indicated. The combination of four arrows and thirteen bells is significant, recalling the four year-bearers, thirteen times repeated during the century of fiftytwo solar years. This jewel may be properly called the escutcheon or heraldic emblem of the cacique or warrior on whose chest it was found.

An analogous gold jewel in the form of a shield with arrows is shown on pl. viII. It is from a codex bound in a volume of manuscripts from Lord Kingsborough's collection in the British Museum, bearing the title, "Descripcion de Indias," tome no. 13964, being a collection of various documents relating to Mexico which were not included by Kingsborough in his monumental work. As this codex is still unpublished, a brief notice of its history will not be out of place. It was first made known to students by the writer, who examined it in 1908. The codex pertained to Tepetlaoztoc, a town about two leagues north of Texcoco in the valley of Mexico. It is on European paper, dates from a

\section{A ND MONOGRAPHS}


period immediately following the conquest, and is one of the most beautifully executed codices that has come down to us. There are many pictures, in colors, of tributes of gold jewels, feather ornaments, and mantles, as well as portraits of the conquerors, accompanied with a text in Spanish giving an explanation of the paintings. The writer communicated the news of its existence to the Duc de Loubat, who in turn notified Troncoso. At the Congress of Americanists held in London in 1912, the codex was exhibited to the members, and a paper was presented by Troncoso (in abstract owing to his absence) describing the codex, in which, in honor of the great Englishman, he called it the "Codex Kingsborough."74 At that time Troncoso sent to London at least two copies of a gelatin reproduction of the codex, in black and white, one of which was presented to the British Museum and the other to Professor Seler. The writer was promised a copy by Troncoso when the other copies were connpleted, but it does not appear that the work was ever carried out. Later, Mr W. E.

\section{N D I A N NOTES}




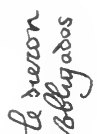

ब.

०ิ क

वั.

5 वै

वर

g कू

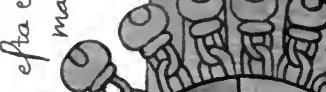
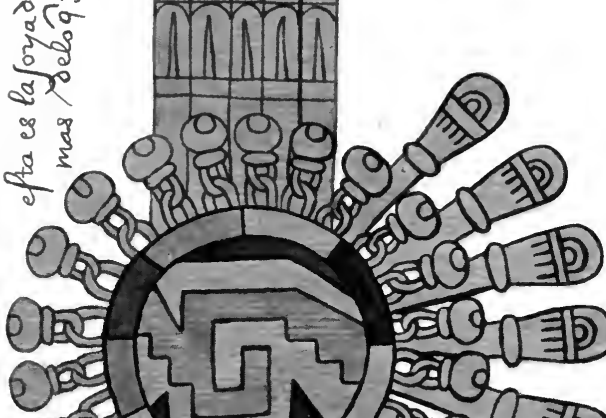

2

$\frac{\text { w }}{\frac{1}{\omega}}$

Z

z

品

$I$

इ $\frac{\pi}{5}$

중

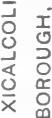

o

z

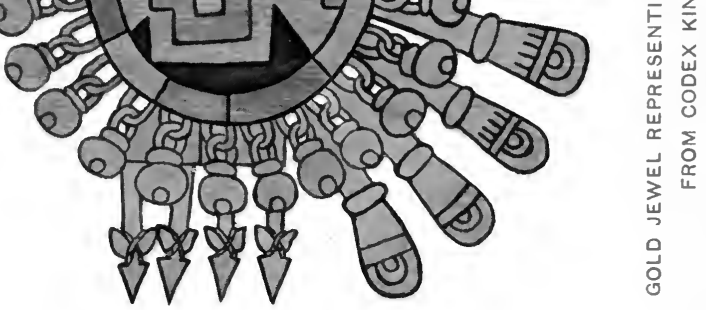



Gates had the manuscript photographed, and several copies were made from the plates. He calls it the "Codex Tepeztlaustuc."75 Recently Miss Annie Hunter has made an exact copy in colors for the Peabody Museum at Cambridge, and we are indebted to Professor Tozzer for permission to use it. Our reproduction of the jewel is from a tracing kindly made by $\mathrm{Mr}$ S. K. Lothrop. This manuscript seems to be the work to which Brinton calls attention in his "Aboriginal American Authors," published in 1883, in which that writer calls on the savants of Spain to locate it, deriving his information of its existence from the 1738 edition of León Pinelo's "Biblioteca Occidental." This citation seems to have been overlooked by Troncoso. The title of the manuscript as given by León Pinelo is, "Memorial del Pueblo de Teptlaustuque en la Nueva España; en que se refiere su Origen, i Poblacion, i de los Tributos, i Servicios, antes, i despues de la Conquista; todo pintado, i M.S."76 It was at that time (1738) in the library of the King of Spain. As the diligent search for

\section{A N D M O N G R A P S}




\begin{tabular}{|l|l|}
\hline 156 & \multicolumn{1}{|c}{ G O L D S M I T H'S A R T } \\
& $\begin{array}{l}\text { material in Madrid made by Sr del Paso y } \\
\text { Troncoso and others during many years } \\
\text { failed to bring this codex to light in that } \\
\text { famous library, it seems probable that the } \\
\text { Kingsborough copy is the original, although, } \\
\text { until a search is made in the King's library, } \\
\text { there is the possibility that it is a copy } \\
\text { made for Kingsborough, and that the } \\
\text { original manuscript still rests in some } \\
\text { obscure recess of the library in the Royal } \\
\text { Palace. } \\
\text { The jewel, represented on folio 223 of the } \\
\text { codex, is quite similar to the one from } \\
\text { Oaxaca, just described. It has within the } \\
\text { disc the same hieroglyph, placed vertically } \\
\text { instead of horizontally, as in the Oaxaca } \\
\text { specimen. It is painted yellow, with blue } \\
\text { between the two sections of the design, and } \\
\text { red outside. The encircling band of the } \\
\text { shield has a mosaic of nine pieces, respec- } \\
\text { tively red, yellow, and blue. The entire } \\
\text { disc is surrounded by twenty-three articu- } \\
\text { lated bells, like sleigh-bells in shape. } \\
\text { Hanging below are eight long pendants } \\
\text { attached to the outer rim of the shield. } \\
\text { Extending from the left side are the fore- }\end{array}$ \\
\hline \multicolumn{1}{|c|}{ I N D I A N N O T E S } \\
\hline
\end{tabular}




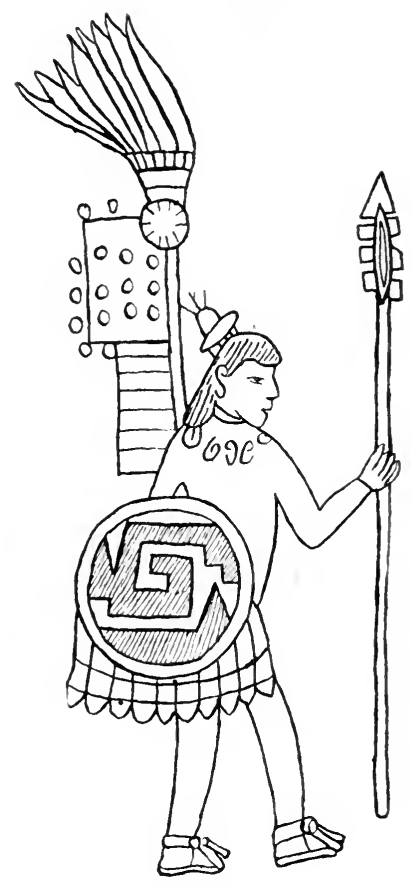

WARRIOR BEARING MOSAIC SHIELD

(After the Tribute Roll of Montezuma) 

shafts of four arrows or darts. Through some oversight five rather long rear-shafts are represented extending from the opposite side. The width of the fore and rear shafts are the same, and it seems evident that the artist drew the outline of one too many rear shafts in making the drawing. Above the jewel is the caption, "Esta es la joya de oro que le dieron mas de los que eran obligados."

There are many illustrations of this hieroglyph on shields in the Mexican codices. Pl. IX is taken from the Tribute Roll of Montezuma, contained in the Mendoza Codex. ${ }^{77}$ On this page of the codex are painted representations of the four principal chiefs of the Aztecan army, each being of one of the great quarters or wards (calpulli) into which Tenochtitlan (City of Mexico), the .capital of Montezuma, was divided. The southwestern ward was named Tecoyahualco, and its chief, shown on pl. IX, was Ticocyahuacatl, who is depicted with a shield of the same design as the jewel, the patterns on the shiclds of the three other chiefs being different.

\section{A N D M O N G R A P H S}


In the atlas accompanying the "Historia de las Indias de Nueva España," by Duran, are two plates showing a captive warrior tied to the temalacatl (a large flat circular stone with a hole in the center), through which a rope was passed, in combat with a warrior clad in a tiger-skin and bearing a shield with the same device. They are both armed with maquahuitls, the sawsword or stick of hardwood with rows of obsidian knives on each edge.

In other parts of the Tribute Roll are numerous representations of the same design on the shields which formed part of the yearly tribute levied by Montezuma, to be paid by hotland provinces. The decoration depending from the shields is in all cases rich green feathers. One example is shown on pl. $\mathrm{x}, b$, which is typical of this class of shields, accompanied by the suit and standard worn by the warrior. ${ }^{78}$ On the same plate $(a)$ is the representation of a warrior with this type of shield, taken from the Humboldt collection of Mexican paintings in Berlin. ${ }^{79}$ Another example, from an original painting in the Museo Nacional

\section{NDIA N NOTES}



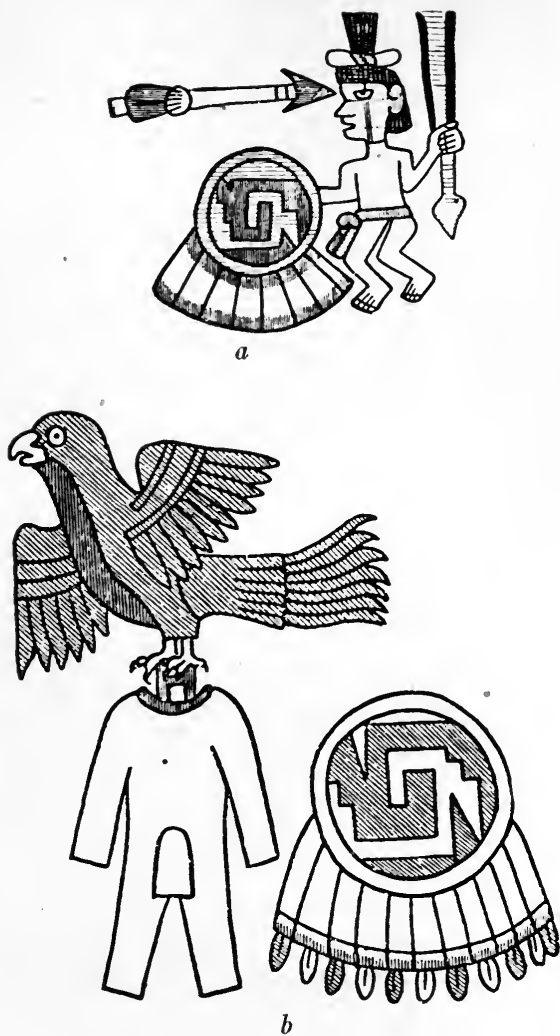

PAINTINGS OF MOSAIC SHIELDS

(After Mexican Codices) 

of Mexico, bears the same design $;^{80}$ it is figured on pl. xI, $b$. On the same plate (a) is a drawing of an original feathermosaic shield now in the Museum of Stuttgart ${ }^{81}$ it bears the same pattern and is placed vertically on the disc, and reversed to that of the Codex Kingsborough. This shield probably formed part of the loot sent by Cortés to Europe, although its history is lost.

We are fortunate in having an explanation of the meaning of this design in the Tribute Roll of Montezuma, above referred to. In the Lorenzana edition, pl. II is the record of payment of twenty shields with this pattern. Below is the inscription, "Vestido de plumas para de medio cuerpo abaxo" (Garment of feathers for the lower part of the body). On other pages of the same codex it is called "military insignia." Above the shield is the Nahuatl legend, "Quilzalxi calcolihuhqui." The first word should be quetzal instead of quilzal, and refers to the hanging quetzal feathers. Yicalcoliuhqui is the name of the design. 'The etymology of the word is xicalli (jicara),

\section{A N D MONOGRAPHS}


calabash, or gourd; coliuhqui, crooked, bent, twisted; hence the crooked or double calabash, or water gourd, is represented in a conventional manner in the design or hieroglyph. The crooked or double gourd for water has been carried from time immemorial by Mexican and Central American Indians, and are even now an everpresent article of use in every Indian hut.

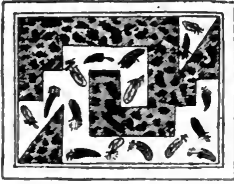

Fig. 8.

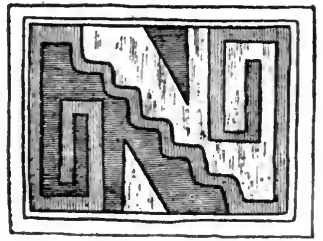

Fig. 9.

Further corroboration of the meaning of the hieroglyph is found in another Mexican codex, in the National Library at Florence, Italy. It was first reproduced in facsimile and published in 1903 by the University of California, under the direction of Mrs Zelia Nuttall, ${ }^{82}$ who brought it to light, and the Duc de Loubat issued another edition in $1904 .{ }^{83}$ A number of pages of this codex

\section{N D A N NOTES}



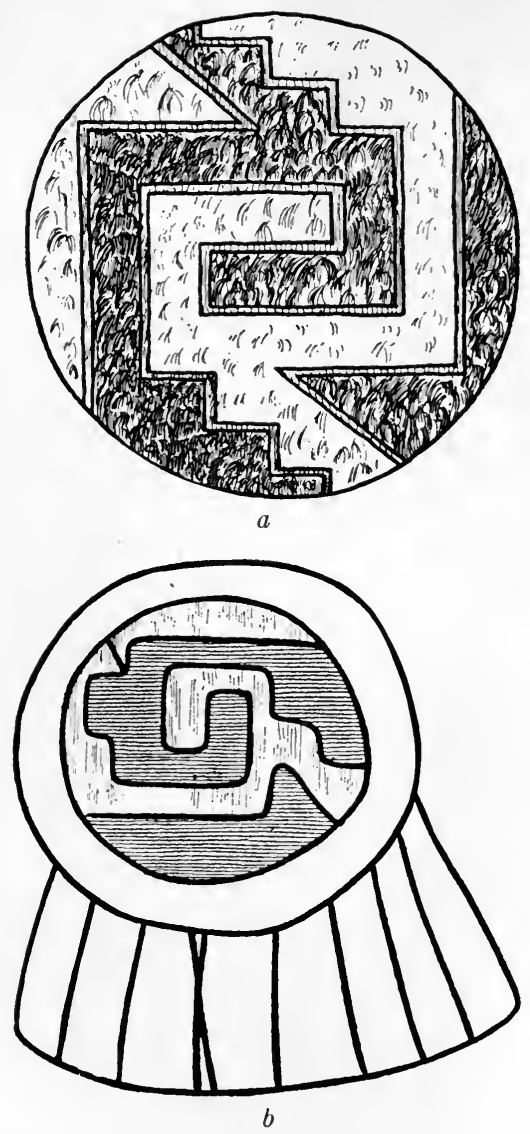

MOSAIC FEATHER SHIELDS

( $a$, In the Stuttgart Museum; $b$, Painting after a Mexican Codex) 



\section{OA X A A J E W L S}

are devoted to patterns of mantas or garments of the ancient Mexicans. On pages 5 and 6 are xicalcoliuhqui patterns (figs. 8 and 9), which are explained as "manta de xicara tuerta," or "mantle with the crooked gourd pattern." There is still another manta pattern of this design in the Codex Kingsborough (fig. 10). The meaning of

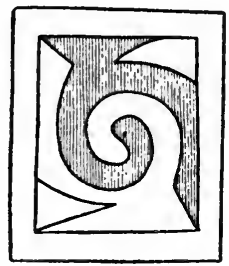

Fig. 10.

this conventional fret or grecque is thus made clear. In other instances the grecque may be derived from the coiled serpent, and again, in Mexican art, there seems reason to suppose that the spiral of the conchshell might be indicated in this conventional form. In all events we here have a pretty clear explanation from two sources

\section{A N D MONOGRAPHS}




\begin{tabular}{|c|c|}
\hline 162 & GOLDSMITH'S ART \\
\hline & $\begin{array}{l}\text { giving the gourd as the derivation of the } \\
\text { design as used on the shields, which might } \\
\text { just as well be derived from either the spiral } \\
\text { of a conch or the coil of a snake. This } \\
\text { sounds the caution which should be em- } \\
\text { ployed by the student of ancient American } \\
\text { art in attributing certain designs to a single } \\
\text { motive, when the same pattern might be } \\
\text { derived from one or more other motives. } \\
\text { In pl. xI are presented three analogous } \\
\text { designs suggestive of the xicalcoliuhqui. } \\
\text { The first outline (a) is a portion of the } \\
\text { grecque design, in highly conventionalized } \\
\text { form, of the stone mosaic-work of the walls } \\
\text { of the Temple of the Columns at Mitla. } \\
\text { The same motive at Mitla has been worked } \\
\text { out by Gordon in his series of climan- } \\
\text { kistron patterns as a direct evolution from } \\
\text { the serpent motive. The next figure (b) } \\
\text { shows the decoration around the rim of a } \\
\text { bowl from Texcoco, in the valley of Mexico, } \\
\text { in which the resemblance to the xicalcoliuh- } \\
\text { qui design is very close. Figure } c \text { of the } \\
\text { same plate is a grecque pattern from the } \\
\text { wall of the Cruciform Tomb at Mitla, dis- } \\
\text { covered by the Loubat Expedition; }{ }^{85} \text { it bears }\end{array}$ \\
\hline & I N I I N NOTES \\
\hline
\end{tabular}



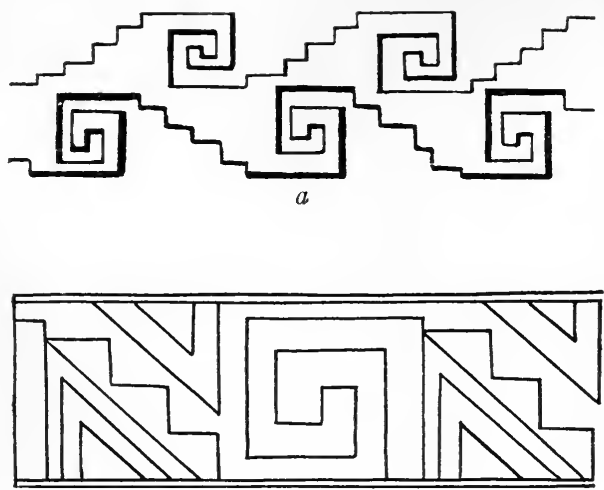

$b$

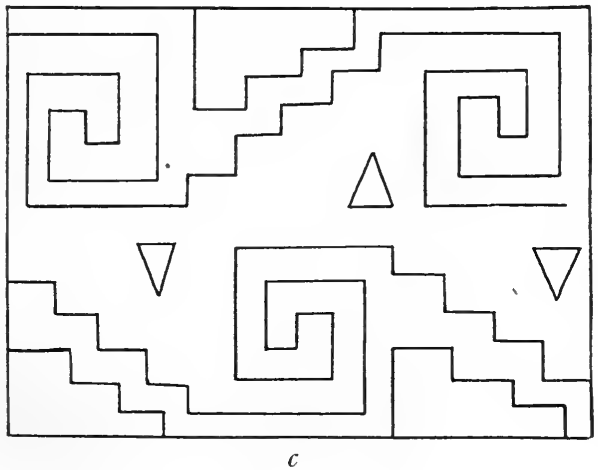

PATTERNS RESEMBLING DESIGNS ON MOSAIC SHIELDS 

close resemblance to the design we are considering, and is the only example with the triangular pieces, characteristic of the xicalcoliuhqui design, which we have found at Mitla. Scores of other examples of this design in Mexico and Central America might be given, but these suffice to indicate its widespread use in this part of America, and to identify it with a degree of certainty, at least in the region of the influence of Nahuan culture, as being derived from the crooked gourd. Its use on shields, as we have pointed out, was restricted to great warriors, and even to one of the four great war-chiefs of Montezuma. Hence the beautiful brooch or jewel must have been buried with a very important chief, and it may correspond, in a way, to the croix de guerre and other military decorations with which we are so familiar at this time.

In the notes of Valentini is the sketch by Berendt of another gold specimen from Oaxaca, here reproduced (pl. xIII, $b$ ), showing the profile of a human face attached to a bar. In a note by Berendt it is said to have been from the Zapoteca. In exam-

\section{A N D MONOGRAPHS}




\begin{tabular}{|c|c|}
\hline 164 & GOLDSMITH'S ART \\
\hline & $\begin{array}{l}\text { ining the works of Batres and Peñafiel we } \\
\text { found the front-view illustration of a } \\
\text { specimen in the Museo Nacional of Mexico, } \\
\text { which is among the specimens Batres } \\
\text { states he brought to the Museum. } 86 \text { In } \\
\text { comparing the.Berendt drawing with that } \\
\text { of this specimen (see pl. xII, a), it will be } \\
\text { readily seen that the two represent the same } \\
\text { object, and we may be certain that it is a } \\
\text { product of Zapotecan art, notwithstanding } \\
\text { the assertion of Peñafiel that, "concerning } \\
\text { its Aztec origin we have not the slightest } \\
\text { doubt, because, it represents the god of } \\
\text { night, Tzontemoc." It is a beautiful } \\
\text { example of this type of the goldsmith's } \\
\text { art, representing a human face with an } \\
\text { ornament in the upper lip and hanging over } \\
\text { the open mouth, and showing a band } \\
\text { extending across the face. The elaborate } \\
\text { headdress is of the filigree style. } \\
\text { On pl. xIv we have copied from the paper } \\
\text { of Dr Nicolas León } 87 \text { the filigree-like } \\
\text { human figure which he has illustrated, } \\
\text { but without description or location, except } \\
\text { that it is from Oaxaca. We are here } \\
\text { reminded of the figure from Vera Cruz }\end{array}$ \\
\hline & I N I A N NOTES \\
\hline
\end{tabular}



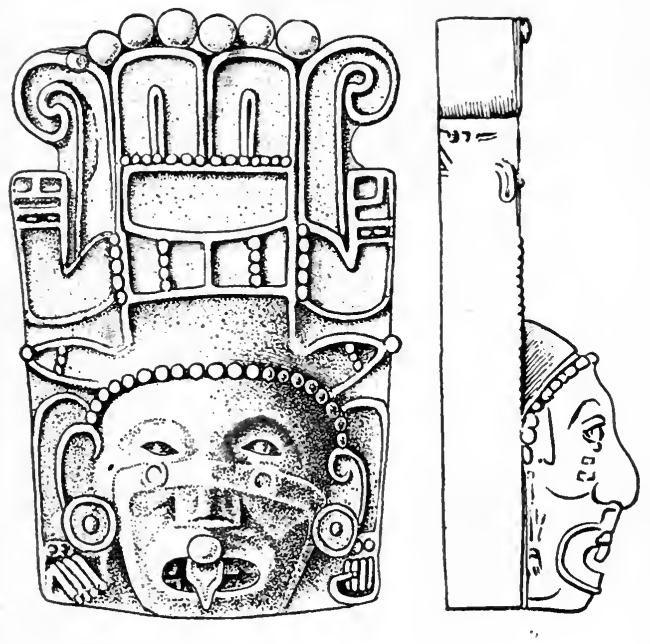

GULD ORNAMENTS FROM THE STATE OF OAXACA (Museo Nacional, Mexico) 



\section{OAXACA JEWELS}

illustrated on pl. XxI, to which further reference will be made.

The next object of this general class (pl. $\mathrm{xv}, a$ ) is one of the most important pieces from the entire Oaxaca region, as well as one of the most recent to come to light. We quote in extenso from the report of Louis M. N. Forsyth concerning the discovery of this and of other objects in the same region. In his paper on Aztec ruins in southern Mexico, ${ }^{88}$ Forsyth illustrates five gold objects, another made of gold and silver, as well as two silver turtles. These specimens were found in the vicinity of Teotitlan del Camino, in the northern part of the state of Oaxaca, near the boundary of Pueblo and Vera Cruz. This author writes:

"A gold idol mask found in El Fuerte of Teotitlan is of soft gold, about $1 \mathrm{in}$. high, and of delicate workmanship [pl. $\mathrm{xv}, a]$. It is composed of two metals - gold and silver, one-half the face (I believe the left side) being of gold, the other half of silver; the parts do not appear to be soldered together, so closely and perfectly are they joined; the whole work is cleverly done, no trace of tools being visible. The figure must have been first cast and afterward polished.

\section{A N D MONOGR A P H S}




\begin{tabular}{|c|c|}
\hline 166 & GOLDSMITH'S ART \\
\hline & $\begin{array}{l}\text { The crown is especially interesting, as it is very } \\
\text { high, and the details of the decoration are dis- } \\
\text { tinct; the sides of the face seem to be covered } \\
\text { with a mantle ornamented with designs. Its } \\
\text { face has a long, crooked nose, is absolutely } \\
\text { expressionless, and on the whole rather resembles } \\
\text { an Egyptian figure. It is a mere shell; indeed, } \\
\text { all the figures, whether of gold, silver, or clay, } \\
\text { are hollow." } \\
\text { "In the same apartment that contained the } \\
\text { grave of the cacique, mentioned at the begin- } \\
\text { ning of Part I, the above figure and a number of } \\
\text { others were found, having been placed in a vase, } \\
\text { which contained a number of hollow gold skulls, } \\
\text { representing death masks, about } \frac{1}{2} \text { in. high- } \\
\text { also cast figures as the rough edges on the inside } \\
\text { and back plainly indicate. The inside is black } \\
\text { and shows other signs that favor this conclusion. } \\
\text { Evidently the figure was cast before it was pol- } \\
\text { ished over; a hieroglyphic sign adorns each side } \\
\text { of the head near the ear. This vase also con- } \\
\text { tained several thin sheets of gold, each having } \\
\text { two holes at its upper end, which suggest their } \\
\text { being pendent ornaments such as earrings, and } \\
\text { the three lower figures in the illustration on } \\
\text { page } 184 \text {, which are plainly earrings [see pl. } \\
\text { xvir, b-d]. With these were also some silver } \\
\text { turtles with rattles in them; a pair of gold } \\
\text { pinchers; a perfect copper needle; several copper } \\
\text { adzes or celts, one of which is herewith repro- } \\
\text { duced. } \\
\text { "All come from El Fuerte with the exception } \\
\text { of the needle, which is from a level foundation } \\
\text { cimiento or house site. These few figures I was } \\
\text { fortunate enough to see, but a great many others }\end{array}$ \\
\hline & I N D A N NOTES \\
\hline
\end{tabular}




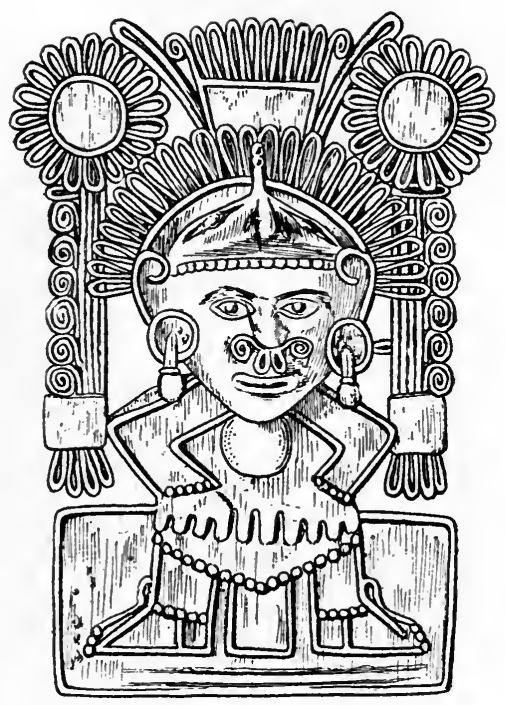





\section{OAXACA JEWELS}

have been melted into gold rings and other ornaments.

"A number of silver and other metallic figures were found in the Mazatec country, which adjoins the region of Teotitlan and pertains to the same district. These figures are, I suppose, Aztec. The Mazatec country is not a mining district, no ore-bearing rocks being found in any section, with the possible exception of Mazatlan, which is near Teotitlan. Teotitlan is a mining country; some of the quartz outcrops along the river banks of the Teotitlan river, showing, by analysis of numerous specimens, some lead, silver, and slight indications of gold; and the mounds in which these gold figures were found resemble in every respect the stone-roofed mounds of the Teotitlan regions. It is, therefore, to be presumed that these metallic objects of the Mazatec regions are of Aztec origin. If such a connection is not well established, the burden of proof would, at least, rest on any assertion to the contrary."

In the same article Forsyth makes the following observation:

"Notwithstanding that the mounds at Pueblo Viejo near the Rio Salado were isolated, they were important graves or houses, and must have been opened about eighty years ago if not later, and doubtless contained valuable relics, possibly of gold and silver, for which reason they attracted the attention of the treasure seekers. It is surprising and regrettable how many important finds have thus been made which, owing to the

\section{A N D MONOGR A P H S}


carelessness of the grave robbers or their ignorance, were melted into rings and other ornaments that could be easily sold. I have seen dozens of such rings made from rare gold idols. Another reason why these figures are melted by the finders is their fear of having them seized by the athorities, for the museums."

The region above described is occupied by the Mazatecs, and their language, according to Belmar, is to be classed as a dialect of the Zapotecan tongue.

Forsyth's final observation, as said before, is true not only of Mexico, but of all other parts of Latin America where gold is found in the graves. Priceless treasures of ancient art have been destroyed for this reason.

We recall the statements of early writers quoted in the first part of this paper regarding the casting of objects in a single piece of alternate sections of gold and silver. The mask from near Teotitlan is the only object of this class now known to the writer from ancient Mexico.

An interesting bell from Tlaxiaco, in the Mixteca (pl. $\mathrm{xv}, b)$, was collected by $\mathrm{Dr}$ Seler and is now in Berlin. It represents a monkey, with the hands grasping a rod

\section{N D I A N N O T E S}



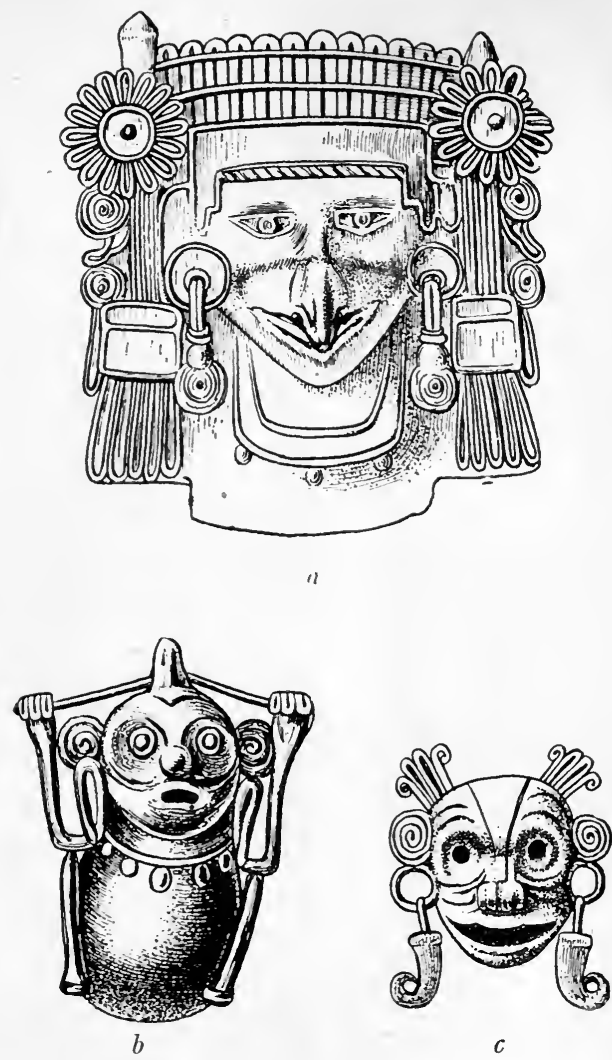

GOLD ORNAMENTS FROM THE STATE OF OAXACA 



\section{OAXACA JEWELS}

held over the head. There is a small ring on the top of the head for attachment. Another object representing the head of a monkey, with pendent articulated earornaments, is shown in $c$ of the same plate; it is in the Sologuren collection, and has been illustrated by Peñafiel and León. ${ }^{89}$ In the same collection is the monkey figure (pl. xvi, b) which has also been illustrated by Peñaficl. ${ }^{90}$ The plate from which the figure rises recalls the gold pieces from Costa Rica and Chiriqui, and this type of object is quite rare in Mexico. Pl. xvI, $a$, represents an analogous monkey-like figure, treated in filigree style; it is not, however, from Oaxaca, but was collected by Strebel from the Cerro Montoso region, in the territory of the Totonaca, state of Vera Cruz, and is now in Berlin. ${ }^{91}$

The objects shown on pl. Xvir have been already mentioned in Forsyth's account of his researches, with the exception of $a$, which is in the Sologuren collection and has been illustrated by Peñafiel. ${ }^{92}$ It is in all respects like the specimens from the Teotitlan region, illustrated and described

\section{A N D MONOGRA P H S}




\begin{tabular}{|l|l|}
\hline 170 & \multicolumn{1}{|c|}{ G O L D S M I T H'S A R T } \\
\hline $\begin{array}{l}\text { by Forsyth, and it may have come from the } \\
\text { same locality, although found many years } \\
\text { previous to the finding of the objects } \\
\text { mentioned by Forsyth. } \\
\text { The writer collected in Oaxaca, for the } \\
\text { American Museum of Natural History, } \\
\text { forty-three gold objects, of which a few } \\
\text { will now be illustrated and described. } \\
\text { These include twenty-eight beads, of which } \\
\text { hundreds, of varying sizes and from widely } \\
\text { different localities, have been found from } \\
\text { time to time, many of them having gone to } \\
\text { the melting-pot. In 1902 forty gold beads } \\
\text { were discovered in a single grave near } \\
\text { Tlacolula, not far from Mitla, and being } \\
\text { covered with earth, their value was not } \\
\text { realized by the Indian who found them, } \\
\text { who sold the handful for twelve reals } \\
\text { (\$1.50 in Mexican currency). These beads, } \\
\text { as a rule, are simple, hollow spheres, but } \\
\text { some time ago a string of fluted beads and } \\
\text { fluted bells was found in a tomb in the } \\
\text { South Side Group at Mitla. In the Amer- } \\
\text { ican Museum of Natural History area single } \\
\text { bead and bell from this tomb. Dr Solo- } \\
\text { guren possessed several from this find, but }\end{array}$ \\
\hline \multicolumn{1}{|c|}{ I N D I A N N O T E S } \\
\hline
\end{tabular}



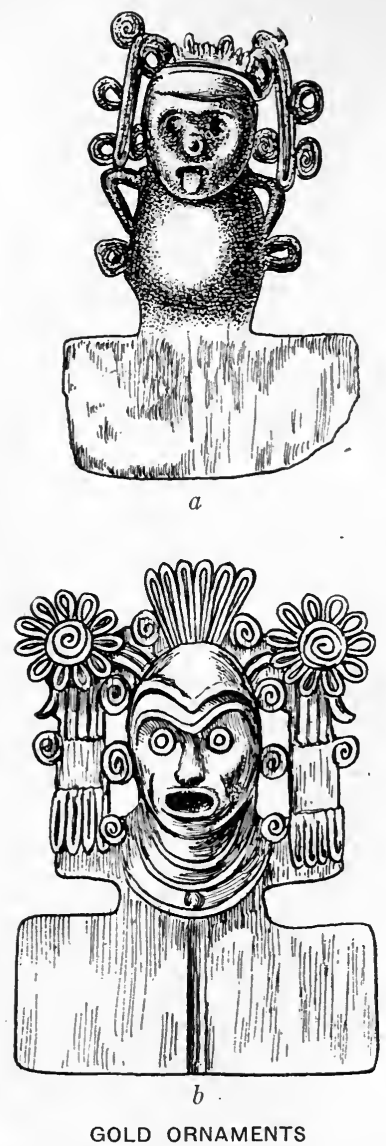

( $a$, From the State of Vera Cruz; $b$, From the State of Oaxaca) 



\begin{tabular}{|c|c|}
\hline OAXACA JEWELS & 171 \\
\hline $\begin{array}{l}\text { the greater number were sold to goldsmiths } \\
\text { and went to the crucible. On pl. xvir,, } c \text {, } \\
\text { we present in colors, natural size, an illus- } \\
\text { tration of a bell similar to the ones from } \\
\text { Mitla, save that this specimen, which is } \\
\text { from Huitzo and in the Sologuren collec- } \\
\text { tion, is slightly larger. It shows the imita- } \\
\text { tion of filigree work around the upper part } \\
\text { and on the ring for attachment. } \\
\text { The splendid eagle's head (quauhtli) } \\
\text { shown in the same plate (a, b) comes from } \\
\text { Juquila, in the southwestern part of Oaxaca, } \\
\text { in Zapotecan territory. It is perhaps the } \\
\text { most esthetic piece in the collection of the } \\
\text { American Museum of Natural History, } \\
\text { and, as regards workmanship, one of the } \\
\text { most perfect jewels yet found in Oaxaca, } \\
\text { although the part by which it was attached } \\
\text { to the garment is missing. The quauhtli } \\
\text { was one of the day-signs of the Nahua } \\
\text { month, and it was also the insignia of a } \\
\text { certain grade of warriors, who attained it } \\
\text { only by valor in actual warfare. }{ }^{93} \\
\text { On pl. xIx, the upper left-hand figure (a) } \\
\text { is a beautiful ornament representing a con- } \\
\text { ventionalized owl's head (tecolotl), from }\end{array}$ & \\
\hline AND MONOGRAPHS & \\
\hline
\end{tabular}




\begin{tabular}{|l|l|}
\hline 172 & \multicolumn{1}{|c|}{ G O L D S M I T H'S A R T } \\
\hline $\begin{array}{l}\text { Achiutla in the Mixteca. It is a symbol } \\
\text { which we have found several times on the } \\
\text { headdress of funeral-urns placed in front of } \\
\text { Zapotecan tombs in the valley of Oaxaca. } \\
\text { It also occurs in stucco on the façades of } \\
\text { tombs and in the hieroglyphic inscriptions } \\
\text { at Monte Alban. The ornament has a } \\
\text { perforation on the top of the head for } \\
\text { attachment to a garment. The inside, } \\
\text { which still shows traces of the black sub- } \\
\text { stance that formed part of the matrix, is } \\
\text { granular, not smoothed and polished like } \\
\text { the outside. } \\
\text { The bell or rattle shown on pl. xIx, } b, c \\
\text { depicts the head of a monkey (ozomatli); it } \\
\text { was found in Huitzo. It is probable that a } \\
\text { sufficient number of bells, alternating with } \\
\text { beads to form a necklace, were found in the } \\
\text { grave which was discovered by an Indian, } \\
\text { as two similar bells were brought to Oaxaca } \\
\text { and sold-one to Dr Sologuren, the other } \\
\text { to Don Abraham Castellanos. The ozo- } \\
\text { matli was one of the twenty day-signs of } \\
\text { the Nahua month. The large object } \\
\text { (pl. xIx, } d \text { ) representing an eagle's head } \\
\text { is a lip-ornament (tentell), and was found in }\end{array}$ \\
\hline \multicolumn{1}{|c|}{ I N D I A N N O T E S } \\
\hline
\end{tabular}



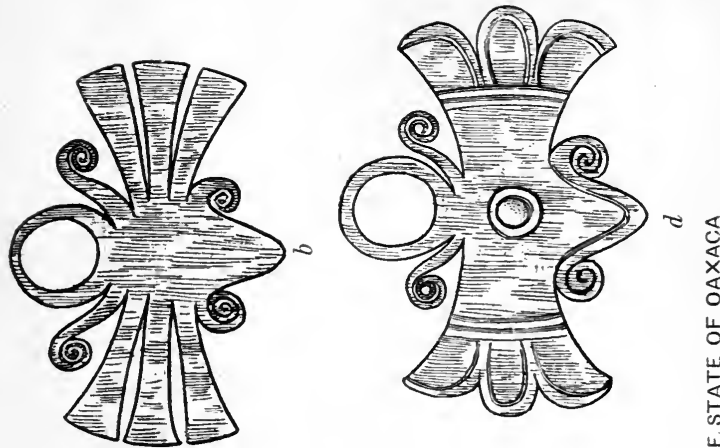

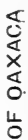

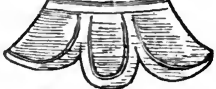

感

I

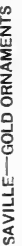
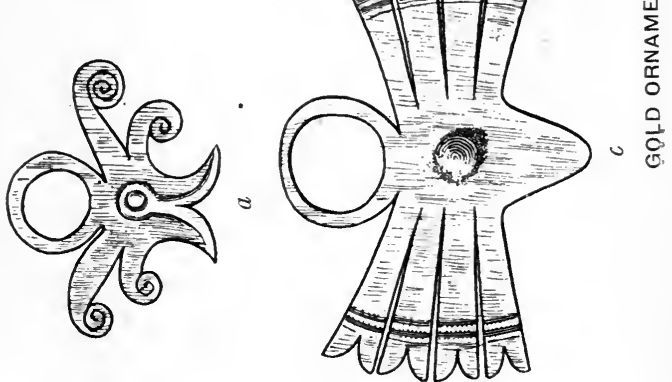

Coatlan, near Miahuatlan. It is the largest labret known from ancient Mexico; indeed it seems almost too large to have been worn by an individual, although labrets larger in diameter, but of different shape, are still worn by old women in British Columbia. It is more likely to have been the lip-ornament of an idol.

In the Sologuren collection and in that of the American Museum of Natural History are other interesting specimens of gold from Oaxaca, which we do not illustrate. Brief mention of several of them will close our discussion of the subject. In the former collection is a small gold frog from Tututepec, south of Juquila, and a similar specimen is in the American Museum of Natural History. At least six similar objects were found in the same grave. The example in the American Museum of Natural History still contains a considerable quantity of the hardened, pulverized charcoal and clay that formed part of the matrix, and is perforated in four places on the under part for attachment to a garment.

Two tiny beads from Nochistlan, in the

\section{A N D MONOGRAPHS}




\begin{tabular}{|c|c|}
\hline 174 & G OLDSM I TH'S A R T \\
\hline & $\begin{array}{l}\text { Mixteca, are modeled in filigree style, } \\
\text { presenting an arrangement of fine gold } \\
\text { wire coiled to make a simple design, and } \\
\text { then cast. There are also four cone-shaped } \\
\text { ornaments with a fringe of tiny beads at } \\
\text { the base. These are hollow, with a bar } \\
\text { across the base for attachment to a gar- } \\
\text { ment. A similar specimen is in the Solo- } \\
\text { guren collection. All came from the same } \\
\text { grave, in Juquila. } \\
\text { Numerous eagle heads, each with open } \\
\text { beak containing the head of a warrior, } \\
\text { were discovered in a tomb in San Antonio } \\
\text { del Alto. They have two perforations at } \\
\text { the back to afford means for attachment. } \\
\text { One of these specimens is now in the Solo- } \\
\text { guren collection, one in the Berlin Muscum, } \\
\text { and two in the American Museum of Natu- } \\
\text { ral History. } \\
\text { A singular ornament in the last men- } \\
\text { tioned Museum is a human molar repre- } \\
\text { sented in gold, from the valley of Oaxaca. } \\
\text { It has two perforations, either for sus- } \\
\text { pension as part of a necklace, or for attach- } \\
\text { ment to a garment. Two other specimens, }\end{array}$ \\
\hline & I N I A N NOTES \\
\hline
\end{tabular}




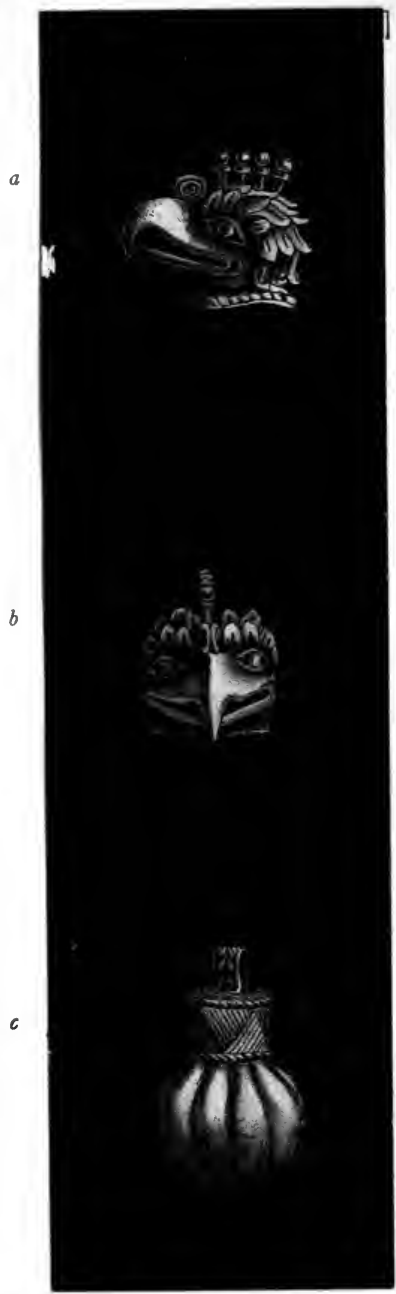

GOLD ORNAMENTS FROM THE STATE OF OAXACA American Museum of Natural History. (Actual size)

I. N. M. -2 



\section{OAXACA JEWELS}

found at the same time, were formerly in possession of Don Francisco Lcón of Oaxaca.

An interesting specimen in the Sologuren collection is a gold disc, $13 \mathrm{~cm} .1 \mathrm{~mm}$. in diameter, recently found in a grave at San Pablo Huitzo. It is a breast ornament, with faint incised lines around the edge, representing the hieroglyph of the sun, tonatiuh. In the center is the hieroglyph ollin, the seventeenth of the twenty daysigns of the Nahuan calendar, and means motion or movement. Hence the meaning of the combined glyphs would be "the movement of the sun," referring to the four seasons of the ycar. Padre Gay mentions that the Mixtecan Indians "sold to some European antiquarians, very thin plates of gold, cvidently worked with the hammer, which their ancestors had been able to preserve, and on which were engraved ancient hieroglyphs." 95

Mrs William Stuart, during her residence in San Gerónimo, in the Tehuantepec region of Oaxaca, was much interested in archeology and accumulated a small collec-

\section{A N D MONOGRAPHS}




\begin{tabular}{|c|c|}
\hline 176 & GOLDSMITH'S ART \\
\hline & $\begin{array}{l}\text { tion. In a short paper Mrs Stuart has the } \\
\text { following note: } \\
\text { "In the neighboring districts, many valuable } \\
\text { specimens have been found during the past ten } \\
\text { years, notably two small gold images, which I am } \\
\text { told have been forwarded to the United States, } \\
\text { and one small gold idol head, weighing one } \\
\text { ounce, which was found some years ago at the } \\
\text { foot of the hill of Ixtaltepec, and presented by } \\
\text { the finder, Count Henri de Gyves, a citizen of } \\
\text { San Geronimo, to the President of the Republic } \\
\text { of Mexico."96 } \\
\text { NAHUAN REGION } \\
\text { From the center of the great region dom- } \\
\text { inated by Montezuma, the valley of Mexico, } \\
\text { as has been already stated, we have almost } \\
\text { no authenticated specimens of the gold- } \\
\text { smith's art. As Penafiel laments: "There } \\
\text { is nothing left of the grand and artistic } \\
\text { wealth of gold and silver articles of the } \\
\text { Aztec empire. The National Museum } \\
\text { [of Mexico] has a few articles, which can } \\
\text { give only an imperfect idea of the work } \\
\text { done by the ancient Mexican silversmiths." } \\
\text { Atzcapotzalco was the greatest manufac- } \\
\text { turing place of gold jewels, and of stone } \\
\text { mosaic-work in which gold was freely used. }\end{array}$ \\
\hline & I N D I A N OTES \\
\hline
\end{tabular}



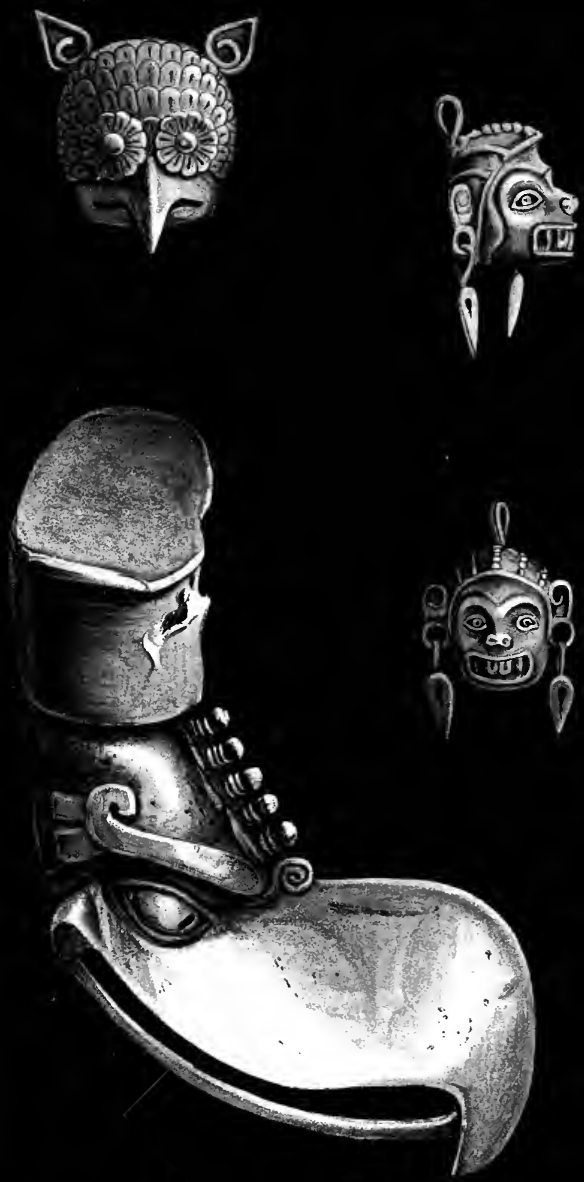

GOLD ORNAMENTS FROM THE STATE OF OAXACA (ICTUAL SIZE) 

Bernal Díaz, in describing the temple of Tenochtitlan, gives some information regarding the erection of the great structure, and says that when it was erected, on the laying of the foundations every inhabitant contributed his mite of gold, silver, pearls, and precious stones, to be buried in the foundations. His interesting description is as follows:

"There was a report that at the time they began to build that great Cue, all the inhabitants of that mighty city had placed as offerings in the foundations, gold and silver and pearls and precious stones, and had bathed them with the blood of the many Indian prisoners of war who were sacrificed, and had placed there every sort and kind of seed that the land produces, so that their idols should give them victories and riches, and large crops. Some of my inquisitive readers will ask how we could come to know that into the foundations of that great Cue they cast gold and silver and precious chalchihuites and seeds, and watered them with the human blood of the Indians whom they sacrificed, when it was more than one thousand years ago that they built and made it. The answer I would give to this is that after we took that great and strong city, and the sites were apportioned, it was proposed that in [the place of] that great Cue we should build a church to our patron and guide, Señor Santiago, and a great part of the site of the great temple of

\section{A N D MONOGRAPHS.}




\begin{tabular}{|c|c|}
\hline 178 & GOLDSMITH'S ART \\
\hline & $\begin{array}{l}\text { Huichilobos was occupied by the site of the holy } \\
\text { church, and when they opened the foundations } \\
\text { in order to strengthen them, they found much } \\
\text { gold and silver and chalchihuites and pearls } \\
\text { and seed pearls and other stones. And a settler } \\
\text { in Mexico who occupied another part of the } \\
\text { same site found the same things, and the officers } \\
\text { of His Majesty's treasury demanded them, } \\
\text { saying that they belonged by right to His } \\
\text { Majesty, and there was a lawsuit about it. I } \\
\text { do not remember what happened except that } \\
\text { they sought information from the caciques, and } \\
\text { chieftains of Mexico, and from Guatemoc, who } \\
\text { was then alive, and they said it was true that } \\
\text { all the inhabitants of Mexico at that time cast } \\
\text { into the foundations those jewels and all the } \\
\text { rest of the things, and that so it was noted in } \\
\text { their books and pictures of ancient things, and } \\
\text { from this cause those riches were preserved for } \\
\text { the building of the holy church of Santiago."98 } \\
\text { The present cathedral in the City of } \\
\text { Mexico is built on the above-mentioned } \\
\text { site, the Spaniards demolishing entirely } \\
\text { the pyramid and ancient temple of the } \\
\text { Aztecs. The present level of the city is } \\
\text { fully ten feet above that of ancient Tenoch- } \\
\text { titlan. It is interesting to have modern } \\
\text { corroborative evidence as to the correctness } \\
\text { of the statement of the old conqueror, } \\
\text { concerning the offerings made when the }\end{array}$ \\
\hline & INDIAN NOTES \\
\hline
\end{tabular}




\section{NAHUAN REGION}

Aztec temple was built. In the year 1900 excavations were conducted in Mexico in connection with laying of pipe for an improved drainage system. In Escalerillas street, back of the cathedral, the deep excavation revealed the foundations of the old temple, and a very large number of objects were found in the mud, which were manifestly placed below the foundations at the time of its erection. The writer was fortunate in being in the city at this time, and on several occasions was permitted to take part in the recovery of objects, during the latter part of the work, in the month of December. Notwithstanding the fact that thousands of specimens were found, but few examples of gold were discovered. These have been noted by Batres ${ }^{99}$ and Seler. ${ }^{100}$ Nine pieces found on October 16 are figured by Batres. Possibly other pieces were discovered and concealed by the workmen, notwithstanding the strict supervision of the work by the Inspector of Monuments, Leopoldo Batres, or by his employees. As Seler writes, "This find of gold is important not only for the value of

\section{A N D M ONOGRAPHS}




\begin{tabular}{|c|c|}
\hline 180 & GOLDSMITH'S AR'T \\
\hline & $\begin{array}{l}\text { the metal, but because there has come } \\
\text { down to us almost no vestige of the famous } \\
\text { art of the ancient Mexican jewelers, for } \\
\text { the reason that the Spaniards did not } \\
\text { appreciate the artistic merit of these objects, } \\
\text { and melted them up." The specimens } \\
\text { recovered were, two gold discs (see pl. xx, } \\
\text { b), perfect and highly polished, with a } \\
\text { diameter of } 20 \text { cm., and with four small } \\
\text { perforations near the rim for suspension. } \\
\text { Discs were called teocuitlacomalli by the } \\
\text { Aztecs, and were used as breast ornaments } \\
\text { by the caciques, and often placed on the } \\
\text { chests of idols, the central piece of a neck- } \\
\text { lace of jadeite beads. Many such are } \\
\text { represented in the codices, and it was the } \\
\text { decoration par excellence of Tezcatlipoca. } \\
\text { "the shining mirror." In the Codex Ra- } \\
\text { mirez this deity is represented with the } \\
\text { breast covered by a circular plate of gold. } \\
\text { He is described as wearing many gold } \\
\text { jewels, and he "wears suspended from the } \\
\text { neck a jewel of gold so large as to cover all } \\
\text { of the breast."101 These discs are identical } \\
\text { with some found in the states of Michoa- } \\
\text { can, Vera Cruz, and Oaxaca, in Mexico, }\end{array}$ \\
\hline & I N D I N NOTES \\
\hline
\end{tabular}



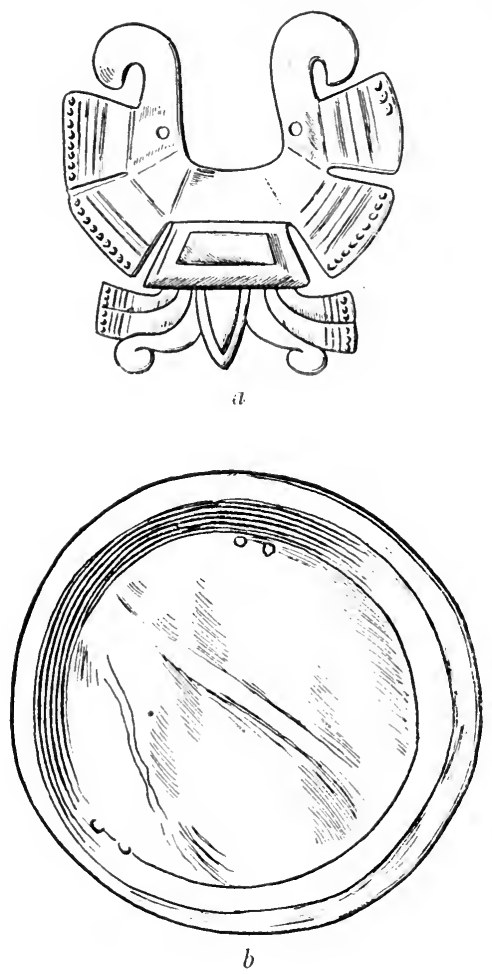

GOLD ORNAMENTS FROM THE CITY OF MEXICO (Museo Nacional of Mexico) 



\section{TARASCAN REGION}

and in Costa Rica, Chiriqui, and South America.

Six other smaller annular discs were found with the two larger ones, all having been bent double. A large ornament for the nose, similar to those shown in many instances in the codices, is illustrated on pl. $\mathrm{xx}, a$; it is $7.8 \mathrm{~cm}$. high and $7.5 \mathrm{~cm}$. wide. This is shaped in the form of the conventionalized butterfly, and is called yaca papalotl, or yaca uicolli. It is the particular attribute of the God of Pulque, of the Goddess of the Earth, and of the Huaxteca people. Small gold beads, undecorated, have been found in the valley of Mexico from time to time, and the writer collected there a gold rattle or bell, in the form of the rattles of the rattlesnake, which is in the collection of the American Museum of Natural History:

\section{TARASCAN REGION}

Gold-leaf applied as a decoration to pottery objects was first presented by Bishop Francisco Plancarte in an interesting report of his explorations in Tarascan

\section{A N D MONOGRAPHS}




\begin{tabular}{|l|l|}
\hline 182 & \multicolumn{1}{|c|}{ G O L D S M I T H S A R T } \\
\hline $\begin{array}{l}\text { territory, in the valley of Zamora, near the } \\
\text { Indian village of Jacona, state of Mich- } \\
\text { oacan, sent to Professor Holmes and pub- } \\
\text { lished in The American Anthropologist in } \\
\text { 1893. In a burial chamber in a small } \\
\text { mound Plancarte dug out some carbonized } \\
\text { and calcined human bones, and among } \\
\text { other objects "gold films or plating and } \\
\text { some five or six fragments of gilded beads, } \\
\text { all mingled with ashes, pieces of coal } \\
\text { lcharcoal], and carbonized remains of tex- } \\
\text { tiles." He further remarks that, "the } \\
\text { great moisture of the place and the action } \\
\text { of time have completely destroyed most of } \\
\text { the gilded objects, leaving only the plates } \\
\text { or films, which I found in rather large } \\
\text { numbers; a few fragments of beads still } \\
\text { retain the gilding." } \\
\text { A short time later, in the early nineties, } \\
\text { Lumholtz, while in the city of Tepic, about } \\
\text { two hundred miles in a direct line northwest } \\
\text { of the place where Plancarte made his } \\
\text { finds, secured some specimens of gold of an } \\
\text { exceedingly interesting character. In his } \\
\text { "Unknown Mexico" he describes and } \\
\text { illustrates some of these specimens. The }\end{array}$ \\
\hline I N D I A N N O T E S \\
\hline the
\end{tabular}




\section{TARASCAN REGION}

183

objects under discussion were found by a native while Lumholtz was on the ground. In a stone grave were two skeletons "around whose necks were altogether twenty-six small bells of solid gold, besides some turquoises. On the breast of one of the dead was a large plate of solid hammered gold which had been used as an ornament."103 The most important piece was a magnificent terra cotta "glazed" jar, ${ }^{104}$ of a technic similar to the vessels which the writer has recently described in an article in the "Holmes Anniversary Volume."105 This vessel is one of the most important examples of ceramic art thus far found in ancient America. It is designed and decorated in imitation of a turkey, and is unique in one particular - the head and neck of the turkey are painted bright red, and the wattles, all clearly indicated, are each ornamented with a thin leaf of gold. Around the neck of the vessel, and in the spaces where the wings, legs, and feet are represented, the "glazed" surface of the vase has been ground off, and this rough surface has been covered with $a_{0}$ thin whitish coat-

\section{AND MONOGRAPHS}




\begin{tabular}{|c|c|}
\hline 184 & GOLDSMITH'S ART \\
\hline & $\begin{array}{l}\text { ing like stucco, which bears traces of a } \\
\text { thin gold-foil covering. The highly fin- } \\
\text { ished surface of this receptacle would not } \\
\text { have retaincd the gold-leaf but for the } \\
\text { grinding-off process, and this piece is the } \\
\text { only one having this treatment which has } \\
\text { come to light, although some of the pottery } \\
\text { from Cholula has thin paint or stucco } \\
\text { applied or worked into unpolished surfaces; } \\
\text { but this ware is not of the "glazed" type, } \\
\text { and no examples have cver been reported } \\
\text { with gold-leaf decoration. This art seems } \\
\text { to be confined to the Tarascan region in } \\
\text { question. } \\
\text { The gold bells from the grave mentioned } \\
\text { are like those of copper found in this region, } \\
\text { while the disc of gold is in every respect } \\
\text { similar to other breast-plates found in dif- } \\
\text { ferent parts of Mexico, and in Central and } \\
\text { South America. } \\
\text { The finds in Michoacan and Tepic } \\
\text { entirely disprove the statements of early } \\
\text { chroniclers that the natives were not good } \\
\text { beaters of gold. The gold-leaf on the } \\
\text { Lumholtz jar is as fine as it would seem } \\
\text { possible to hammer it, even with the best }\end{array}$ \\
\hline & I N IU A N NOTES \\
\hline
\end{tabular}




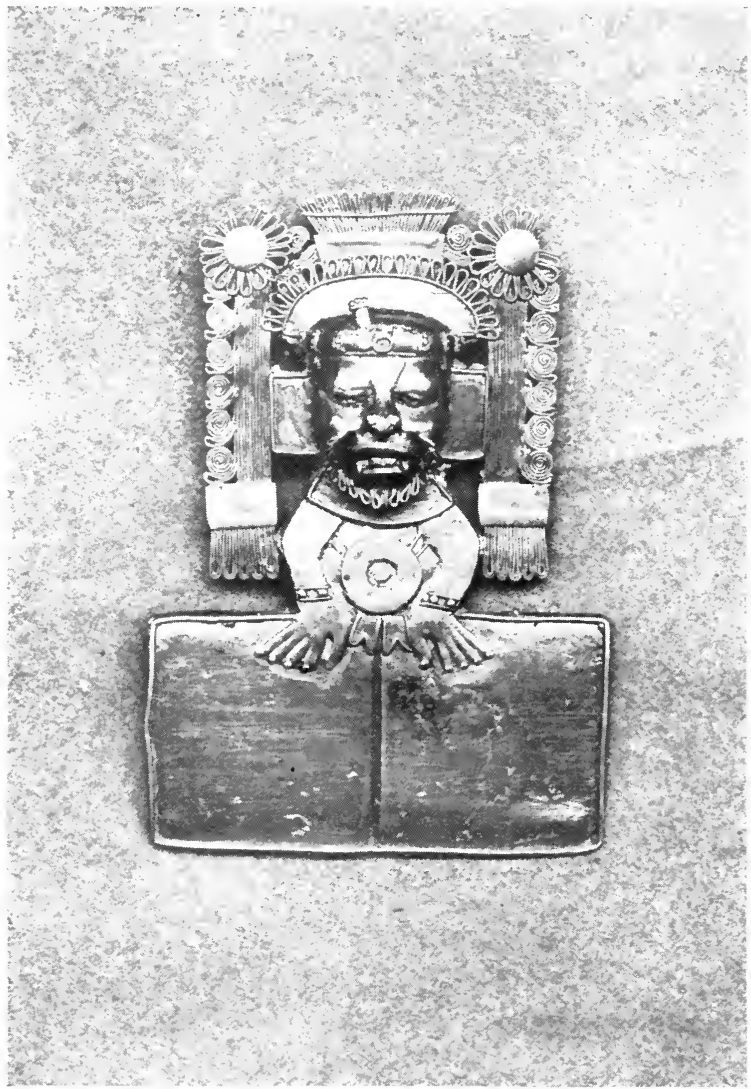

GOLD ORNAMENT FROM THE RUINS OF PAPANTLA, STATE OF VERA CRUZ 
t) 


\section{TOTONACAN, REGION}

modern tools. As we have before stated, other examples of the use of gold-leaf may be seen in several specimens of beautifully carved atlatls, or throwing-sticks, in various European museums, which undoubtedly were sent to Europe in the first period of the conquest, and they still preserve their gilt.

Dr Hamy has described the model of a gold tooth perforated for suspension for a necklace. It was found in Tepito, and Hamy considers it a trophy brought from Michoacan by a soldier of one of the kings Axayacatl or Montezuma. ${ }^{106}$

\section{TOTONACAN REGION}

The large jewel illustrated on pl. xxI is from the ruins of Papantla, otherwise known as El Tajin, in the state of Vera Cruz. ${ }^{107}$ It is $11.5 \mathrm{~cm}$. high, and bears in relief on the reverse of the plate, below the figure, in Nahuan hieroglyphs, the date 4 Ocelotl (tiger) of the year 1 Acatl (reed). This specimen, which is in the Museo Nacional of Mexico, ${ }^{108}$ represents a man with closed eyes, and with an elaborate

\section{A N I $M O N O G R A P H S$}




\begin{tabular}{|c|c|}
\hline 186 & GOLDSMITH'S ART \\
\hline & $\begin{array}{l}\text { head-dress. A peculiar feature is what } \\
\text { appears to be a sparse beard simulated by } \\
\text { a line of wire loops extending around the } \\
\text { chin from near the base of the nose. Large } \\
\text { squares extend from the sides of the face, } \\
\text { either covering or replacing the ears. A } \\
\text { decorated band with a projection in the } \\
\text { center runs around the forehead. On the } \\
\text { chest is an annular disc similar to those } \\
\text { found back of the cathedral in the City of } \\
\text { Mexico. The imitation of filigree work is } \\
\text { noteworthy. As a whole this piece is the } \\
\text { most elaborate specimen of gold-work } \\
\text { which we now know from Mexico, with the } \\
\text { exception of the Zapotecan ornament on } \\
\text { pl. Iv. Although found in present Toto- } \\
\text { nacan territory, the hieroglyphs suggest } \\
\text { that it should be attributed to the Nahuan } \\
\text { people. } \\
\text { In the foregoing study of the goldsmith's } \\
\text { art in ancient Mexico, we have aimed to } \\
\text { present the sources of information concern- } \\
\text { ing it, rather than to enter into a definitive } \\
\text { treatment of the art itself. The evidence }\end{array}$ \\
\hline & I N D A N NOTES \\
\hline
\end{tabular}




\section{CONCLUSION}

is sufficient to show that the Mexicans had attained a high proficiency in this class of work. From the descriptions of the many gold jewels and of objects in which gold was used as a decoration, which we derive from the inventories, as well as of the few jewels recently found in ancient tombs, it is clear that the extravagant statements of the early chroniclers are not highly exaggerated. That so much revealing the artistic temperament of the Mexicans has been irretrievably lost is a matter of lasting regret. So far as the few specimens of gold from Mexico justify us in making a comparison with the same class of objects from other parts of ancient America, we are safe in placing these jewels as works of barbaric art on a higher plane generally than those of the inhabitants of Chiriqui, $\mathrm{Co}$ lombia, Ecuador, and Peru. Certain very small gold jewels from the province of Esmeraldas, Ecuador, are in a distinct class, and the wonderful hollow figures, bottles, and canteens from the region of the Quimbayas in Colombia may possibly be excepted from the above assertion. The

\section{A N D MONOGRAPHS}




\begin{tabular}{|c|c|}
\hline 188 & GOLDSMITH'S ART \\
\hline - & $\begin{array}{l}\text { combination of stone-mosaic with gold was } \\
\text { probably in vogue among the ancient Pe- } \\
\text { ruvians, but the writer cannot recall ever } \\
\text { seeing any specimens of that kind. Such } \\
\text { mosaics from the coast of Peru are on shell } \\
\text { and wooden matrices. Mosaics have also } \\
\text { been found in the great Southwestern cul- } \\
\text { ture area in the United States. The writer } \\
\text { once found traces of mosaic-work in an } \\
\text { ancient tomb in the valley of Oaxaca, and } \\
\text { the occurrence of one or two other instances } \\
\text { of such fragments in other parts of Mexico } \\
\text { have come to our attention. The jewel } \\
\text { which we have illustrated is thus far the } \\
\text { only specimen that shows the artistic } \\
\text { character of this work.109 The great region } \\
\text { where gold was used in abundance was that } \\
\text { occupied by the Nahuas, Zapotecs, Mixtecs, } \\
\text { and Tarascans, together with the coast } \\
\text { region of Vera Cruz. } \\
\text { We have not taken into account the } \\
\text { Mayan region, where the first specimens of } \\
\text { jewels were obtained on the coast of Yuca- } \\
\text { tan, Campeche, and Tabasco. Very few, } \\
\text { if any, gold jewels have been found in } \\
\text { Mayan tombs. The only important finds }\end{array}$ \\
\hline & I D I A N NOTE \\
\hline
\end{tabular}


of this kind were those made in the great cenote in Chichen Itza, Yucatan, where they were thrown into the water as ceremonial offerings, with many other objects. These have not yet been described, nor are they at present available for study.

At the present time the goldsmiths of Mexico are exceedingly clever in making gold and silver filigree objects, probably more so than in any other part of Latin America. It is perhaps a survival on the part of the present-day Indians of the art which flourished on the Mexican plateau in the early part of the sixteenth century. But the mosaic-work, and especially the even more interesting feather-mosaic which was truly an esthetic achievement, are arts that have passed away, owing to the complete subjugation and subsequent degradation of one of the highest cultures of ancient America.

\section{NOTES}

1. Peter Martyr, De Orbe Novo, Fourth Decade, book $\mathrm{x}$.

2. This expedition has been the subject of inquiry by the writer in a recently published

\section{AND MONOGRAPHS}




\begin{tabular}{|c|c|}
\hline 190 & GOLDSMITH'S ART \\
\hline & 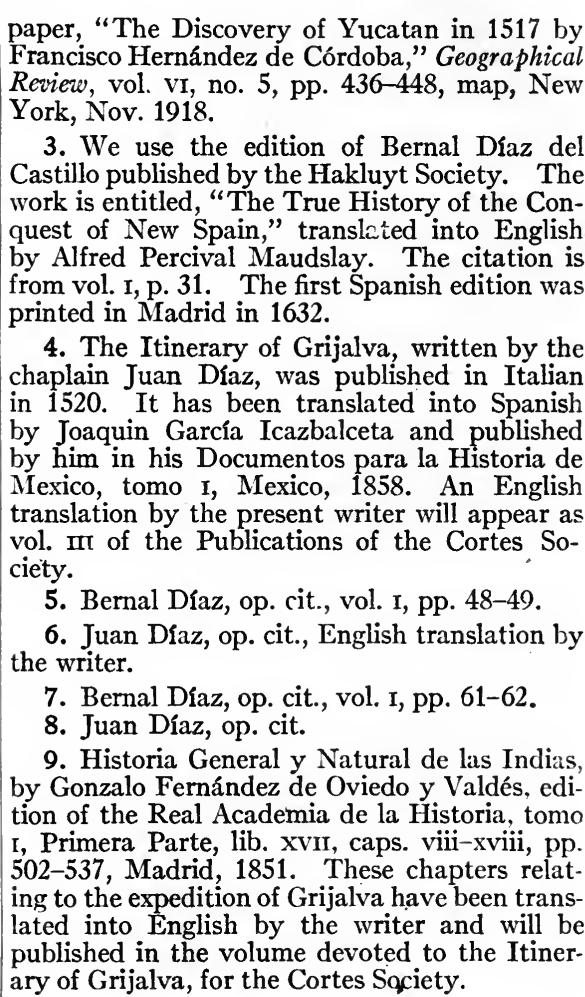 \\
\hline & I N I A N NOTES \\
\hline
\end{tabular}


10. Francisco Lopez de Gomara, Conquista de México, Segunda Parte de la Cronica General de las Indias, edition of Don Enrique de Vedia, Historiadores Primitivos de Indias, in Biblioteca de Autores Españoles, tomo I, pp. 298299, Madrid, 1877.

11. Peter Martyr, op. cit. I quote from the latest translation made and edited by Francis A. MacNutt, vol. II, book III, p. 16, New York, 1912.

12. The writer has called attention to the finding of gold fishhooks on the Ecuadorian coast in his "Archeological Researches on the Coast of Esmeraldas. Ecuador," in Verhandlungen des XVI Internationalen Amerikanisten-Kongresses, p. 341, Vienna, 1909.

13. These valuable gifts are described in the work of Bernal Díaz del Castillo, Andrés de Tápia, and a serving man who saw them in Vera Cruz. They were examined in Sevilla by Oviedo y Valdés, and in Valladolid by Peter Martyr and Father Las Casas, the latter two writers giving us more detailed descriptions than any of the others. The anonymous writer of a letter dated November 7, 1519, of which copies are extant in both Spanish and German, saw them in Sevilla, and they are mentioned also in a letter of the same date written by a servant named Diego Dienz. This is all the source material known in regard to the treasure written by eye-witnesses, with the possible exception of the account of Gomara, later chaplain to Hernan Cortés. His description seems too exact to have been written secondhand, but he makes

\section{A N D MONOGRAPHS}




\begin{tabular}{|c|c|}
\hline 192 & GOLDSMITH'S ART \\
\hline & $\begin{array}{l}\text { no specific statement of the fact. He follows } \\
\text { closely the description of Las Casas, and pos- } \\
\text { sibly had access to the manuscript of his work. } \\
\text { All the other authorities cited write that they } \\
\text { had seen the objects. We give here, in extenso, } \\
\text { the various accounts of the treasure. The first } \\
\text { and longest by a companion of Cortés is that of } \\
\text { Bernal Diaz. He writes: "The first article pre- } \\
\text { sented was a wheel like a sun, as big as a cart- } \\
\text { wheel, with many sorts of pictures on it, the } \\
\text { whole of fine gold, and a wonderful thing to } \\
\text { behold, which those who afterward weighed it } \\
\text { said was worth more than ten thousand pesos. } \\
\text { Then another wheel was presented of greater } \\
\text { size made of silver of great brilliancy in imita- } \\
\text { tion of the moon with other figures shown on it, } \\
\text { and this was of great value as it was very heavy } \\
\text { and the chief brought back the helmet full of } \\
\text { fine grains of gold, just as they are got out of } \\
\text { the mines, and this was worth three thousand } \\
\text { pesos. This gold in the helmet was worth more } \\
\text { to us than if it had contained twenty thousand } \\
\text { pesos, because it showed us that there were } \\
\text { good mines. Then were brought twenty golden } \\
\text { ducks, beautifully worked and very natural } \\
\text { looking, and some lornaments] like dogs, of the } \\
\text { kind they keep, and many articles of gold } \\
\text { worked in the shape of tigers and monkeys, and } \\
\text { ten collars beautifully worked and other neck- } \\
\text { laces; and twelve arrows and a bow with its } \\
\text { string, and two rods like staffs of justice, five } \\
\text { palms long, all in beautiful hollow work of fine } \\
\text { gold. Then there were presented crests of gold } \\
\text { and plumes of fine feathers, and others of silver. } \\
\text { and fans of the same material, and deer copied }\end{array}$ \\
\hline & I N I A N NOTES \\
\hline
\end{tabular}




\section{NOTES}

in hollow gold, and many other things that I . cannot remember, for it all happened so many years ago."-Op. cit., vol. I, chap. xxxix, pp. 143-144.

Captain Andrés de Tápia does not give any extended description, simply saying that Montezuma "ordered that the Marquis should be given a certain present of gold and silver, and in it was a wheel of gold, and another of silver, each one the size of a cart-wheel, although not very thick, which they said were made in the semblance of the sun and moon." Relacion de Andrés de Tápia sobre la Conquista de Mexico, published by Joaquin García Icazbalceta, in Colección de Documentos para la Historia de Mexico, tomo II, p. 562, Mexico, 1866.

Francisco de Aguilar is quite as brief, for he writes only that "here they were given a present of a golden sun among some weapons, and a moon of silver, and certain golden collars, which were sent to the emperor.'

Finally, we have the letter written by a servant to his master from New Sevilla near the port of Archidoma, under date of June 28, 1519. It enumerates "two round discs, one of fine gold, the other of finesilver, finely worked with beautiful figures out of free hand, which were given to the Captain. The gold disc is seven palms broad and seven palms long, the other of silver is the little finger smaller.

"Furthermore: the head of a great snake or dragon, which is a figure of very fine gold, with gold teeth: this is a full palm broad, and three fingers thick, note how large this head is. The

\section{A N D MONOGRAPHS}




\begin{tabular}{|c|c|}
\hline 194 & GOLDSMITH'S ART \\
\hline & $\begin{array}{l}\text { eyes are of costly precious stones, and decor- } \\
\text { ated with costly feathers. } \\
\text { "Furthermore: a great disc of precious } \\
\text { stones; it is on the inside and outside lined with } \\
\text { a tiger-skin, which skins are very highly valued. } \\
\text { "Furthermore: four necklaces with many } \\
\text { costly stones mounted in gold. } \\
\text { "Furthermore: a horn of a seafish made of } \\
\text { gold, two palms long and about two palms } \\
\text { broad, entirely of gold. } \\
\text { "Furthermore: a head of gold, and many } \\
\text { other pieces of gold and silver and precious } \\
\text { stones." } \\
\text { After the arrival of the treasure in Sevilla on } \\
\text { November 5, it was seen by several person whose } \\
\text { writings have come down to us. An anonymous } \\
\text { letter written to Juan de la Pena in Burgos is } \\
\text { dated two days after its arrival in Sevilla. A } \\
\text { similar letter has been found, undated, indited to } \\
\text { the Archbishop of Granada. There can be no } \\
\text { doubt that the two were composed by the same } \\
\text { person, but the first letter contains a few more } \\
\text { details than the latter. } \\
\text { Oviedo saw the treasure in the House of } \\
\text { Trade in Sevilla, and writes about the great } \\
\text { quantity of gold "given to Hernando Corté } \\
\text { and the Spaniards, especially two great wheels. } \\
\text { one of gold and the other of silver, like metal } \\
\text { plates, worked in medium relief; the one of gold } \\
\text { they had in reference of the sun, and that of } \\
\text { silver in memory of the moon. The one of gold } \\
\text { weighed four thousand, eight hundred pesos. } \\
\text { and that of silver forty-eight and fifty marks; } \\
\text { each one was nine and one-half palms wide and } \\
\text { thirty in circumference. Which [things] I saw }\end{array}$ \\
\hline & I NDIAN NOTES \\
\hline
\end{tabular}


in Sevilla, in the House of Trade, with many other jewels of gold and silver." Oviedo states that he talked with the proctors, Montejo and Portocarrero, and the pilot Alaminos, and this was "almost at the end of 1519."

Peter Martyr describes these objects after an examination of them, for in the Fifth Decade, written to Pope Adrian VI, he writes regarding the gifts which Cortés received from Montezuma in person in the city of Tenochtitlan, that "the gifts Cortés received from Montezuma are so marvelous, both for their intrinsic value and for their workmanship, that it is better not to describe them until we see them. In company with Your Beatitude, we have examined in the famous city of Valladolid the first ones sent over, and we have described them in our Fourth Decade. Cortés writes that within a few days he will send a number of presents, but that the first to reach us are much inferior in number, quality, and value."

The description of Peter Martyr, referred to above by him, was dedicated to Pope Leo X. We quote it in extenso, using the Eden translation, but have given modern spelling to the text.

"Let us now therefore come to the other presents which were brought to the king. Among these were two broad and round plates (which some have named the images of the sun and moon), the one of silver and the other of gold, in largeness and roundness much like to the stones of hand mills: yet but thin, and in manner both of one of circumference, that is, xxviii spans in circuit. That of gold is of the

\section{A ND MONOGRAPHS}




\begin{tabular}{|c|c|}
\hline 196 & GOL D S M T H'S A R T \\
\hline & $\begin{array}{l}\text { weight of three thousand and viii hundred cas- } \\
\text { tellans, where as we have said before that a } \\
\text { castellane is a coin of gold which weigheth more } \\
\text { than a ducat by a trient, that is the third part } \\
\text { of a pound. In the center of this, was the im- } \\
\text { age of a king of half a cubit long, sitting in a } \\
\text { throne and appareled to the knee, like unto a } \\
\text { maumette, with such countenance as our painters } \\
\text { are wont to paint fairies or sprites. About the } \\
\text { image, were the shapes of trees and flowers, so } \\
\text { that it seemed to sit as though it had been in a } \\
\text { field. The other, of silver, was made to the } \\
\text { same similitude, being also in manner of the } \\
\text { same weight, and both of pure metal. They } \\
\text { brought likewise certain grains of rude gold } \\
\text { (that is such as was never molten) about the } \\
\text { bigness of fitches or the pulse called lentils in } \\
\text { token of plenty of native gold. Also two chains } \\
\text { of gold, whereof the one contained viii links in } \\
\text { the which were set two hundred three score and } \\
\text { two fair and clear red stones, and yet no rubies: } \\
\text { furthermore, a hundred and four score and } \\
\text { three green stones, and yet no emeralds. Nev- } \\
\text { ertheless, these are in like estimation with } \\
\text { them, as the other are with us. At the edge of } \\
\text { this chain, there hang xxvii golden bells, having } \\
\text { between every. [one] of them, four jewels of } \\
\text { precious stones enclosed in gold, at every [one] } \\
\text { of the which in like manner hang certain spangles } \\
\text { of gold. The other chain consisteth only of } \\
\text { four golden links, beset round about with a } \\
\text { hundred and two red stones, and a hundred } \\
\text { threescore and twelve green stones, with xxvi } \\
\text { golden bells curiously wrought and placed in } \\
\text { comely order. In the very midst of the chain, }\end{array}$ \\
\hline & INDIAN NOTES \\
\hline
\end{tabular}


are ten great precious stones enclosed in gold, at the which also hang a hundred golden pendants of cunning workmanship. They brought furthermore twelve pair of leather buskins of divers colors, some embroidered with gold and some with silver, with plates and jewels of gold and precious stones enclosed, and at every [one] of them certain golden bells. Also certain miters beset with precious stones of divers colors, among the which some are blue, like unto sapphires. Of crests, girdles, and fans made of feathers, I wot not what I should say. But surely if ever the wits and inventions of men have deserved honor or commendation in such arts, these seem most worthy to be had in admiration. I do not marvel at gold and precious stones. But am in manner astonished to see the workmanship excel the substance. For I have with wondering eyes beheld a thousand forms and similitudes, of the which I am not able to write. And in my judgment, I never saw any thing whose beauty might so allure the eye of men. As they marveled at the natural beauty of the feathers of our peacocks and pheasants, so did we no less marvel at the artificial beauty of such things as they make of feathers and quills impaled with gold. For I saw in many of their works, all manner of native colors even in the quills whereof they make such instruments.

"They brought also two helmets garnished with precious stones of a whitish blue color. One of these is edged with bells and plates of gold, and under every bell two knobs of gold. The other, beside the stones wherewith it is

\section{A N D MONOGRAPHS}




\begin{tabular}{|c|c|}
\hline 198 & GOLDSM I TH'S A R T \\
\hline & $\begin{array}{l}\text { covered, is likewise edged with xxv golden bells } \\
\text { and knobs: and hath on the crest, a green bird } \\
\text { with the feet, bill, and eyes cf gold. Also four } \\
\text { spears much like unto trout or eel spears, the } \\
\text { wood whereof is all covered with quills of divers } \\
\text { colors marvelously wreathed with gold wires and } \\
\text { plates intermixed. Every [one] of these spears } \\
\text { have three pikes, whose edges or teeth are all of } \\
\text { precious stones made fast with wires of gold. } \\
\text { Of like workmanship they brought a great } \\
\text { scepter beset with precious stones and bells of } \\
\text { gold, also a bracelet of gold, and shoes made of } \\
\text { a hart's skin, sewed and embroidered with golden } \\
\text { wires, with a white sole beneath. Furthermore } \\
\text { a glass [mirror] of a bright blue stone, and an- } \\
\text { other of white, both enclosed in gold. Like- } \\
\text { wise a precious stone of the kind of them that } \\
\text { are called Sphinges [sphinx], enclosed in gold. } \\
\text { Furthermore the head of a great lizard, two } \\
\text { great shells, two ducks, the shapes of divers } \\
\text { other birds, fowls, and fishes, and all of massive } \\
\text { gold. Furthermore xxiil round and square tar- } \\
\text { gets, shields, and bucklers of gold, and five of } \\
\text { silver. Also a triple crown of plates, and wires } \\
\text { of gold marvelously wreathed with quills and } \\
\text { feathers of divers colors, having on the front a } \\
\text { plate of gold on the which is graven the image } \\
\text { of the idol Zemes. About this image, hang four } \\
\text { other plates like cresses of gold in the which } \\
\text { are graven the heads of divers beasts, as lions, } \\
\text { tigers, wolves, and such other. They brought } \\
\text { also the similitudes of certain beasts made some } \\
\text { of rods or twigs, and some of wood with the } \\
\text { beasts' own skins thereon, and garnished with } \\
\text { collars of laton bells. Iikewise divers sheets }\end{array}$ \\
\hline & I N I A N NOTES \\
\hline
\end{tabular}


weaved of gossampine cotton of sundry colors whereof two are richly fringed with gold, and precious stones, and three other with quills and feathers intermixed with gossampine cotton of sundry colors and checkered like the panes of a chess board. Some are on the one side, of black, white, and red colors: and on the other side, plain without any variety. Other some, are wrought in like manner with variable colors with a wheel or circle of black in the midst intermixed with shining feathers and sparks of gold like stars. They brought also cloth of Aras or Verdure of marvelous workmanship. Likewise a soldier's cloak such as their princes wear in the wars, with certain privy coats of fence, and sundry tirements pertaining to their heads, with also many such other things more beautiful to the eye than rich or precious, whereof to entreat particularly, it should be more tedious than profitable."-The Decades of the Newe Worlde of West India, etc., London, 1555, Arber reprint, the First Three English Books on America, Westminster, 1895, pp. 197198. The description of the Cortés booty by Peter Martyr, given above, was first published in Latin in "De Nvper svb D. Carolo Repertis Insulis, simulatque incolarum moribus, R. Petri Martyris, Enchiridion, Dominæ Margaritæ, Diui Max. Caes filiæ dictatum," Basileæ, Anno M.D.XXI, 44 pp. This was translated integro by Eden. Our extract is found on pp. $36-39$ of the 1521 edition.

The account of Las Casas follows:

"A present of such rich things, fabricated and made of such workmanship that they ap-

\section{A N D MONOGRAPHS}




\begin{tabular}{|l|l|}
\hline \multicolumn{1}{|c}{ G O L D S M I T H'S A R T } \\
\hline $\begin{array}{l}\text { peared like a dream, and not as if made by } \\
\text { man's hands. There was a diversity of small } \\
\text { shirts, and some very delicate and varicolored } \\
\text { cotton cloths, for the vestments such as they } \\
\text { were accustomed to wear, intermingled with } \\
\text { very delicate and divers colored bird's feathers: } \\
\text { a helmet, I think [made] of wood, very thin, } \\
\text { and covered with grains of gold [such as used] } \\
\text { for smelting: a helmet of plates of gold, and little } \\
\text { bells hanging [from it], and on it stones like } \\
\text { emeralds: many shields made of certain thin } \\
\text { and very white rods, intermingled with feath- } \\
\text { ers, and discs of gold and of silver, and some } \\
\text { very small pearls, like misshapen pearls, the } \\
\text { workmanship of which no one can express in } \\
\text { writing, nor its beauty, richness and loveliness: } \\
\text { certain plumes of large divers colored feathers, } \\
\text { with the ends of gold embroidery, hanging down: } \\
\text { fans of very rich feathers, with a thousand } \\
\text { beautiful decorations of gold and silver, and of } \\
\text { marvelous workmanship: armlets and other } \\
\text { pieces of armor of gold and silver, that they } \\
\text { were accustomed to use in their wars in such a } \\
\text { way that with their green and yellow feathers } \\
\text { intermingled, and reddish deer-skins very well } \\
\text { tanned, one could not duly describe their work- } \\
\text { manship and beauty: sandals of very well } \\
\text { tanned deer-skin sewed with gold threads, and } \\
\text { for soles, a white and blue stone, a precious } \\
\text { thing very thin and with very delicate upper } \\
\text { soles of cotton: mirrors made of margasita } \\
\text { (marcasita, pyrites?) which is a very beautiful } \\
\text { metal like silver, very shining, and these mirrors } \\
\text { [are] large like a fist, round like a ball, set in } \\
\text { gold, that leaving out the value of the gold, }\end{array}$ \\
\hline \multicolumn{1}{c}{ I N D I A N N O T E S } \\
\hline
\end{tabular}


only for the workmanship and beauty of them, one might sell at a high price, and which might be presented to any lord and great king as a suitable present: many mantles and curtains for the bed, very thin [made] of cotton, which seemed to be finer and richer than if made of silk, and made of divers colors: many pieces of gold and silver: a necklace of gold which had more than one hundred emeralds, and many more rubies, or what seemed to be [rubies], from which hang many little golden bells: another [necklace] with many emeralds, and certain rich pearls, and of admirable workmanship: other small pieces of gold, like frogs and little animals, and jewels like large and small medals, which only for the hand-work as they say, or of the beauty of the artifice with which they were fashioned, were worth more than the value of the gold and silver, and a great deal more: many grains of gold for smelting, as it is taken out of the mines, like chickpeas, and larger. Above all this they sent two wheels, one of gold [with] the figure of the sun carved on it, with its rays and ornaments, and certain figures of animals designed on it. I think it weighed more than one hundred marks: the other of silver, with the figure of the moon carved in the same manner as that of the sun, [weighing] fifty and some odd marks. It has the thickness of a toston of four reales, both [are] massive. Each one is very little smaller in roundness than a cart-wheel. These wheels were certainly things well worth seeing. I saw them with all the other things, in the year 1520 in Valladolid, the day that they were

\section{A N D MONOGRAPHS}




\begin{tabular}{|c|c|}
\hline 202 & GOLDSMITH'S ART \\
\hline & $\begin{array}{l}\text { seen by the Emperor, for they arrived there } \\
\text { then, sent by Cortés, as God be pleased, it will } \\
\text { be seen below. All those who saw those things, } \\
\text { so rich and beautiful, as things that had never } \\
\text { been seen nor heard of before, chiefly because } \\
\text { until then, things like them had never been } \\
\text { seen before, remained surprised and greatly } \\
\text { astounded. The Indians said that that present } \\
\text { and those gifts were sent by Montezuma to } \\
\text { those who had come there these passed days, } \\
\text { who were Juan de Grijalva and his companions, } \\
\text { only that when they had arrived at the sea-coast } \\
\text { with them, they [Grijalva and his men] had } \\
\text { already departed. The gold and silver which } \\
\text { was there was valued at twenty to twenty-five } \\
\text { thousand castellanos, but their beauty and } \\
\text { workmanship make them worth as much more." } \\
\text { - Historia de las Indias, tomo Iv, cap. cxxi, } \\
\text { pp. 284-286, Madrid edition, } 1876 \text {. } \\
\text { Gomara first speaks of the presents received } \\
\text { by Cortés as follows: } \\
\text { "Thus they passed seven or eight days, } \\
\text { receiving many visits from the Indians, and } \\
\text { awaiting the coming of the Governor, and the } \\
\text { answer from that great lord [Montezuma] as } \\
\text { he was called by all. He [the Governor] arrived } \\
\text { presently with a very handsome and rich } \\
\text { present. There were many mantles and pieces } \\
\text { of clothing of embroidered white and colored } \\
\text { cotton, such as they used. Many plumes and } \\
\text { other lovely feathers, and some things made of } \\
\text { gold and feathers, rich and beautifully orna- } \\
\text { mented. A quantity of jewels and pieces of } \\
\text { silver and gold, and two thin wheels, one of } \\
\text { silver, weighing fifty-two marks, with the }\end{array}$ \\
\hline & I N D I N NOTES \\
\hline
\end{tabular}




\section{NOTES}

figure of the moon [on it], and the other of gold, weighing one hundred marks, made like the sun, with many decorations and animals in relief, a very beautiful work. They hold these two objects in that land as gods, and make them of the color of metal they resemble. Each one measured ten palms in width and thirty around. These presents may be valued at twenty thousand ducats or a little more. The said present they had [brought] to give to Grijalva if he had not departed [before they arrived], according to what the Indian said."

Gomara's itemized list begins:

"The two wheels of gold and silver given by Teudilli from Montezuma.

"A necklace of gold [composed] of eight pieces, in which there were set one hundred and eighty-three small emeralds, and two hundred and thirty-two small stones similar to rubies not of great value; from it hung twenty-seven little bells of gold, and some heads of pearls or berruecos.

"Another necklace [composed] of four crooked pieces, with one hundred and two small rubies, and one hundred and seventy-two small emeralds, ten fine pearls not badly set, and with a border of twenty-six little bells of gold. Both necklaces were well worth seeing. and they had other beautiful things without those mentioned.

"Many grains of gold, none larger than the size of chick-peas, such as are found on the soil.

"A plain helmet [filled] with grains of unsmelted gold, unrefined, and not accounted for.

"A head-piece of wood, covered with gold

\section{A N D MONOGRAPHS}




\begin{tabular}{|c|c|}
\hline 204 & GOLDSMITH'S ART \\
\hline & $\begin{array}{l}\text { and covered outside with much mosaic-work, } \\
\text { and for bebederos? [perhaps a misprint for } \\
\text { babaderos, bibs] twenty-five little golden bells, } \\
\text { and for a crest [it has a green bird with the } \\
\text { eyes, bill, and feet of gold. } \\
\text { "A helmet of small gold plates and little } \\
\text { gold bells around it on the outside, and covered } \\
\text { with stones. } \\
\text { "A bracelet of very thin gold. } \\
\text { "A rod like a royal scepter, with two rings } \\
\text { of gold for the ends, and decorated with pearls. } \\
\text { "Four tridents with three hooks covered } \\
\text { with feathers of many colors, and [with] the } \\
\text { points of pearls tied with gold thread. } \\
\text { "Many shoes like sandals, of deer-skin sewed } \\
\text { with gold thread, with the soles of a certain } \\
\text { white and blue stone, very thin and transparent. } \\
\text { [Clavigero translates this as "the soles of which } \\
\text { were made of blue and white stone it:tli, very } \\
\text { thin." In a note Clavigero says, "Gomara } \\
\text { does not say expressly that the stone was itztli, } \\
\text { but it is to be understood from his' account."] } \\
\text { "Six other pairs of shoes of a leather of } \\
\text { various colors, decorated with gold, silver, or } \\
\text { pearls. } \\
\text { "A shield of wood and leather, and around } \\
\text { it little bells of Moorish brass [?], the main part } \\
\text { a plate of gold, sculptured on which is Vitcilo. } \\
\text { puchtli, god of battles, and in each quarter four } \\
\text { heads with their feathers or hair in natural } \\
\text { size, alive or flayed, which [heads] were a lion. } \\
\text { tiger, eagle, and an owl. } \\
\text { "Many skins of birds and animals, tanned. } \\
\text { with their feathers and hair. }\end{array}$ \\
\hline & I N I A N NOTES \\
\hline
\end{tabular}




\section{NOTES}

"Twenty-four shields of gold, feathers, and rude pearls, very handsome and of much beauty.

"Five shields of feathers and silver.

"Four golden fishes, two ducks, and other birds, hollow and cast of gold.

"Two large golden shells, which are not found here, a frightful crocodile, with many thick threads of gold around it.

"A bar of brass [probably burnished copper ${ }^{7}$ and made from the same, certain hatchets ar some spades.

"A large mirror adorned with gold and other smaller ones.

"Many miters and crowns of worked feathers and gold, and with a thousand colors and pearls and stones.

"Many feathers very handsome and of all colors, not dyed but natural [color].

"Many feather-pieces and plumes, large, handsome and rich, with gold and rude pearl mosaic-work.

"Many fans and feathers, and [some] only of feathers, large and small of all sorts, but all very beautiful.

"A mantle like a cloak of woven cotton, of many colors and of feathers, with a black wheel in the center, with its rays, and plain in the center.

"Many surplices and vestments of priests, veils, altar cloths, and ornaments of temples and altars.

"Many others of these mantles of cotton, of white only, or white and black checkered, or red, green, yellow, blue, and other colors also. Yet on the wrong side [they were] always with-

\section{A N D MONOGRAPHS}




\begin{tabular}{|c|c|}
\hline 206 & GOLDSMITH'S ART \\
\hline & $\begin{array}{l}\text { out fleece or color, on the right [out]side } \\
\text { fleecy like plush. } \\
\text { "Many short shirts, jackets, kerchiefs for } \\
\text { the head, of cotton, for men. Many mantles } \\
\text { for the bed, cloths and spreads of cotton. } \\
\text { "These things were more beautiful than } \\
\text { costly, although the wheels were very precious, } \\
\text { and the workmanship was worth more than the } \\
\text { things themselves, because the colors of the } \\
\text { cotton sheets were exceedingly fine, also those } \\
\text { of feathers [were] of natural colors. The cast } \\
\text { work exceeded the skill of our silversmiths, of } \\
\text { which we shall speak in the proper place."- } \\
\text { Op. cit., pp. 313, 322-323. } \\
\text { 14. This inventory was published by } \\
\text { Navarrete in } 1842 \text {, at the end of the "Rela- } \\
\text { cion del descubrimiento y conquista de Nueva } \\
\text { España, hecha por la Justicia y Regimiento de } \\
\text { la nueva ciudad de Villa Rica de Vera Cruz, } \\
\text { a } 10 \text { de julio de } 1519, \text {, in Coleccion de Doct- } \\
\text { mentos Inéditos para la Historia de España, t. I, } \\
\text { pp. } 461-472 \text { It was utilized by Prescott in his } \\
\text { Conquest of Mexico, appearing in } 1843 \text {; he gives } \\
\text { a very free translation of a few of the items. } \\
\text { It was reprinted by Mora in Mexico in 1844, } \\
\text { as an appendix to his Spanish translation of } \\
\text { Clavigero's Historia Antigua de Mexico y de } \\
\text { su Conquista. Finally, it was included by } \\
\text { Gayangos in his edition of the Cartas y Rela- } \\
\text { ciones de Hernan Cortés, published in Paris in } \\
\text { 1866. } \\
15 \text {. The word guarique, unintelligible to } \\
\text { Mora, was thought by Gayangos "to be the } \\
\text { Arabic waric, which signifies work of leaves." } \\
\text { But Oviedo y Valdés, in describing the barter }\end{array}$ \\
\hline & I N I A N NOTES \\
\hline
\end{tabular}


obtained by Grijalva, states that it was a kind of ear ornament, for he mentions "a pair of guariques, or carcillos (earrings, probably hoopshaped), of gold for the ears." (Op. cit., tomo I, lib. XVII, cap. xiii, p. 521.)

16. Pascual de Gayangos, op. cit., second letter of Cortés, p. 85.

17. Fray Bernardino de Sahagun, Historia General de las Cosas de Nueva España, edition of Carlos María de Bustamante, México, 1829, lib. doceno, cap. xvii, pp. 25-26.

18. Francisco Cervantes de Salazar, Crónica de la Nueva España, lib. cuarto, cap. xlvii, p. 378, edition of the Hispanic Society of America, Madrid, 1914.

19. Fray Diego Duran, Historia de las Indias de Nueva España y Islas de Tierra Firme. The original manuscript is in the Biblioteca Nacional, Madrid, and there are copies in the New York Public Library and the Museo Nacional, Mexico. A copy was in the collection of manuscripts gathered by Lord Kingsborough, but it was not published in his monumental work. At the sale of his collection in 1842 it was purchased by Sir Thomas Phillips; it was sold in the section of his library disposed of in June, 1919, and is now owned by John B. Stetson, of Philade! phia. The Kingsborough copy consists of 2543 pages bound in two thick folio volumes, and is illustrated with about one hundred and twenty water-color drawings. The work was published in Mexico, from the copy there, the first volume, annotated by José Fernando Ramírez, coming out in 1867. The final volume and atlas of plates were not

\section{A ND MONOGRAPHS}




\begin{tabular}{|c|c|}
\hline 208 & GOLDSMITH'S ART \\
\hline & 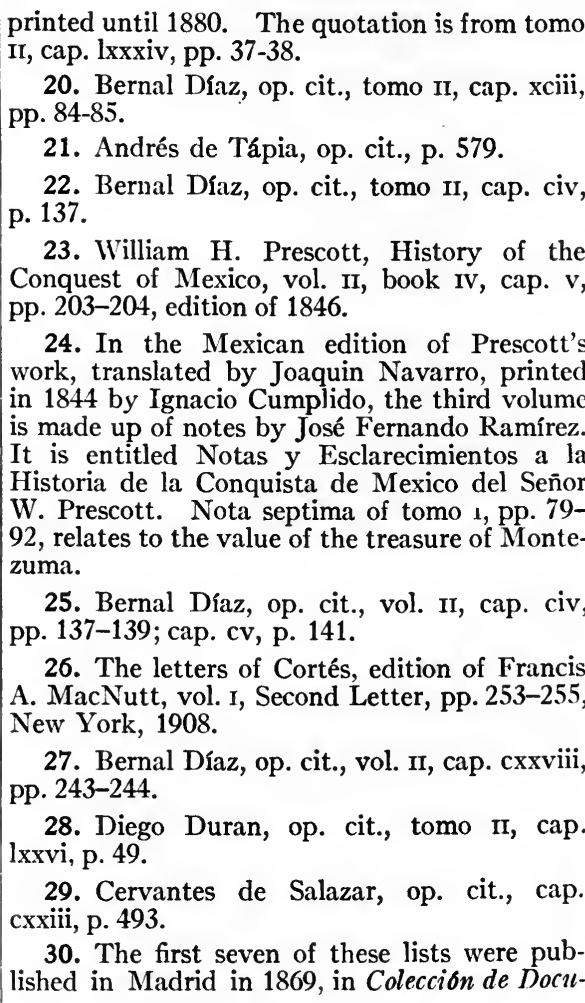 \\
\hline & I NDIAN NOTES \\
\hline
\end{tabular}




\begin{tabular}{|c|c|}
\hline NOTES & 209 \\
\hline $\begin{array}{l}\text { mentos Inéditos Relativos al Descubrimiento, } \\
\text { Conquista y Organisacion de las Antiguas Poses- } \\
\text { iones Fs pañolas sacados de los archivos del Reino } \\
\text { y muy Especialmente del de Indias, por D. Luis } \\
\text { Torres de Mendoza, tomo xII. The last inven- } \\
\text { tory has recently been found by Fr. Cuevas and } \\
\text { published in Cartas y Otras Documentos de } \\
\text { Hernan Cortés Novisimamente Descubiertos en } \\
\text { el Archivo General de Indias de la Ciudad de } \\
\text { Sevilla é ilustrados por el P. Mariano Cuevas, } \\
\text { S. J., pp. 21-25, Sevilla, 1915. } \\
31 \text {. Gayangos writes that "two officers } \\
\text { called Alonso de Avila and Antonio de Quiñones } \\
\text { were entrusted with the carrying to Castile of } \\
\text { the letters and errand [Montezuma's treasure]; } \\
\text { moreover in the island of Santa Maria of the } \\
\text { Azores, where the boat made port, Quiñones } \\
\text { died in a night brawl, and Avila continued his } \\
\text { voyage, escorted by two other caravels of } \\
\text { Domingo Alonso. They fell in with some } \\
\text { French corsairs near the head of Cape San } \\
\text { Vicente, and the rich spoils of the Aztecs went } \\
\text { to fill up the treasure of Francis I." One } \\
\text { of the accompanying caravels, called Sancti } \\
\text { Spiritus, was saved, the pirates being content } \\
\text { simply to rob the ship of its rich cargo, and } \\
\text { dllowed it to proceed: From an extract of the } \\
\text { Registro de la Contralacion we learn that this } \\
\text { vessel entered the port of Sevilla on November } 7 \text {, } \\
\text { 1522. } \\
\text { 32. See note } 30 \text {. } \\
33 \text {. William Robertson, History of America, } \\
\text { book vit, note xxxiv. This work was concluded } \\
\text { in } 1788 \text {. } \\
34 \text {. Alexander von Humboldt, Researches }\end{array}$ & . \\
\hline A N D MONOGRAPHS & \\
\hline
\end{tabular}




\begin{tabular}{|c|c|}
\hline 210 & GOLDSMITH'S ART \\
\hline & $\begin{array}{l}\text { Concerning the Institutions and Monuments of } \\
\text { the Ancient Inhabitants of America, translated } \\
\text { into English by Helen Maria Williams, vol. I, } \\
\text { p. 183, London, } 1814 \text {. } \\
\text { 35. Bernal Día, op. cit., vol. II, pp. 127-128. } \\
\text { 36. Cortés, op. cit., vol. I, pp. 242-244. } \\
\text { 37. The history of this, one of the most } \\
\text { important of Mexican codices, is too long for } \\
\text { details here The original Tribute Roll on } \\
\text { maguey paper is now in the National Museum } \\
\text { of Mexico, and has been recently reproduced in } \\
\text { colors by Peñafiel. A copy on European paper, } \\
\text { made before 1550, also in colors, forms part of } \\
\text { the so-called Codex Mendoza, or Codice Mendo- } \\
\text { cino, now in the Bodleian Library at Oxford. } \\
\text { Several fragments of leaves of the maguey paper } \\
\text { original are in the rooms of the American Philo- } \\
\text { sophical Society of Philadelphia. The writer } \\
\text { has had the privilege of examining them in the } \\
\text { various places they are now preserved, and has } \\
\text { had access to all the publications in which they } \\
\text { are reproduced. At some future time he hopes } \\
\text { to publish a complete account of this codex. } \\
38 \text {. The reproduction of the Tribute Roll } \\
\text { is found in Monumentos del Arte Mexicano } \\
\text { Antiguo, by Dr Antonio Peñafiel, tomo II, pl. } \\
228-259 \text {, Berlin, } 1890 \text {. } \\
\text { 39. The Tribute Roll was published by } \\
\text { Archbishop Lorenzana of Mexico, in his His- } \\
\text { tory of New Spain, being the Letters of Cortés, } \\
\text { Mexico, } 1770 \text {. He took it from the original } \\
\text { maguey paper codex, and it appears under the } \\
\text { title, Cordillera de los Pueblos que antes de } \\
\text { la Conquista pagagaban Tributo a el Em- }\end{array}$ \\
\hline & INDIAN NOTES \\
\hline
\end{tabular}


perador Muctezuma y en que especie, y cantidad. There are 31 plates.

40. The Codex Mendoza, containing the Tribute Roll, was included by Lord Kingsborough in his monumental work, in nine volumes, on the Antiquities of Mexico, London, 1831-33, from the European paper copy in Oxford. The codex is reproduced in colors, in the first 72 plates of vol. I, the Tribute Roll being the second part, pl. 19-57. In vol. v, pp. 37-126, is the explanatory text, pp. 54-89 explaining the Tribute Roll. Several of the towns mentioned in this Tribute Roll will be found in the extract of the letter by Cortés which we have just quoted in extenso.

41. A translation, by the writer, of the Anonymous Conqueror, has been published by the Cortes Society as vol. I of the Documents and Narratives Concerning the Discovery and Conquest of Latin America. The title is, Narrative of Some Things of New Spain and of the Great City of Temestitan, Mexico, written by the Anonymous Conqueror, a Companion of Hernan Cortes, p. 79, New York, 1917.

42. Andrés de Tápia, op. cit., pp. 582-583.

43. Antonio de Herrera, Historia de las Indias Occidentales, edition of A. Gonzales Barcia, Madrid, 1726-30, Dec. II, lib. vi, cap. xii, p. 155.

44. Padre Horacio Carochi, Arte de la Lengua Mexicana, p. 77, 1st ed., Mexico, 1645.

45. Brinton's Library of Aboriginal American Literature, no. vII, Ancient Nahuatl Poetry, introd., p. 29, Philadelphia, 1887.

\section{A N D MONOGRAPHS}




\begin{tabular}{|c|c|}
\hline 212 & GOLDSMITH'S ART \\
\hline & $\begin{array}{l}\text { 46. Brinton, ibid., p. } 65 \text {. This song is a } \\
\text { part of a collection which was undoubtedly } \\
\text { brought together by Father Sahagun. Brinton } \\
\text { published a portion of them from a faulty copy } \\
\text { made by Brasseur de Bourbourg. Dr Peña- } \\
\text { fiel has issued a sumptuous edition of the songs, } \\
\text { in facsimile, under the title, Cantares en Idioma } \\
\text { Mexicano, Mexico, 1904. In his Colección } \\
\text { de Documentos para la Historia de México. } \\
\text { México, } 1899 \text {, Peñafiel printed a transcription of } \\
\text { these songs, made from the original manuscript } \\
\text { which is conserved in the Biblioteca Nacional. } \\
\text { City of Mexico. As yet the only translation } \\
\text { which the writer knows of is that into English } \\
\text { by Brinton, which includes fewer than a third } \\
\text { of the songs. } \\
\text { 47. Brinton, in his Library of Aboriginal } \\
\text { Literature, no. vin, "Rig Veda Americanus } \\
\text { Sacred Songs of the Ancient Mexicans," pp. } \\
56-58, \text { first published the original text and an } \\
\text { English translation. This song is part of a } \\
\text { collection contained in the Nahuatl version of } \\
\text { Sahagun's great History of the Things of New } \\
\text { Spain, as yet unpublished, and conserved in } \\
\text { the private library of the King of Spain. Seler } \\
\text { later made a copy of the collection and pub- } \\
\text { lished them with a translation into German and } \\
\text { with copious explanatory notes in his Gesam- } \\
\text { melte Abhandlungen zur Amerikanischen Sprach- } \\
\text { und Alterthumskunde, Bd. II, Berlin, 1904. } \\
\text { Seler shows that the translations of Brinton are } \\
\text { exceedingly faulty. On this subject see the } \\
\text { paper by Seler, On Ancient Mexican Religious } \\
\text { Poetry, in Proceedings of the International Con- } \\
\text { gress of Americanists, 13th Session, New York, } \\
\text { pp. 171-174. }\end{array}$ \\
\hline & INDIAN NOTES \\
\hline
\end{tabular}




\section{NOTES}

48. On this point consult the work of Sahagun. See note 58 .

49. The following are some of the more common words used in connection with gold objects: teocuitlamecall, a chain or necklace; mecatl, a cord; teocuitlamaquiztli, a gold bracelet; maquiztli, bracelet; teocuitlacoscatl, gold jewel; cozcall, jewel; teocuillacomalli, gold plate or disc; comalli, the clay griddle of circular form; teocuitlacoyolli, gold bell; coyolli, bell. See Alonzo de Molina, Vocabulario Mexicano, Mexico, 1571.

50. "Those who stole silver and gold were flayed alive, and sacrificed to the god of the goldsmiths and silversmiths who was called Xipe, and were taken through the streets as a warning to others, for it was a crime against the false god." Vetancurt, Teatro Mexicano, tomo I, Parte segundo, Tratado tercero, cap. xiii, p. 484, second ed., Mexico, 1870. 65-67.

51. Anonymous Conqueror, op. cit., pp.

52. Obras Historicas de Don Fernando de Alva Ixtlilxochitl, tomo II, Historia Chichimeca, cap. xxxvi, p. 180, published in Mexico in 1892 under the editorship of Alfredo Chavero.

53. Kingsborough edition, op. cit., vol. I, pl. 71, fig. 24 .

54. The Mappe Tlotzin once formed a part of the Collection of Boturini. It is mentioned by him in his Catalogo del Museo Indiano, Madrid, 1746, in sec. III, no. 3, p. 4. It was acquired by Aubin, and later by Goupil, being now in the Boturini Aubin-Goupil Collection

\section{A ND MONOGRAPHS}




\begin{tabular}{|c|c|}
\hline 214 & GOLDSMITH'S A R T \\
\hline & $\begin{array}{l}\text { in the National Library, Paris. It has been } \\
\text { published in colors, pl. I-IIr, in Mémoires sur la } \\
\text { Peinture Didactique et l' Ecriture Figurative } \\
\text { des Anciens Mexicains, par J. M. A. Aubin, } \\
\text { with an introduction by E. T. Hamy, Paris, } \\
\text { 1885. The illustration we give is on pl. II. } \\
\text { 55. Fray Toribio de Motolinia, Historia de } \\
\text { los Indios de la Nueva España, in Colección de } \\
\text { Documentos para la Historia de Mexico, publi- } \\
\text { cada por Joaquin García Icazbalceta, tomo I, } \\
\text { cap. xiii, pp. } 212-213 \text {, Mexico, 1858. } \\
\text { 56. Two gilded atlatls came to light a few } \\
\text { years ago in Florence which are splendid ex- } \\
\text { amples of this class of decoration. They have } \\
\text { been illustrated and described by David I. } \\
\text { Bushnell, Jr., in the article "Two Ancient } \\
\text { Mexican Atlatls," published in the American } \\
\text { Anthropologist, N. s., vol. 7, no. 2, April-June, } \\
\text { 1905, pp. 218-221, pl. xxi-xxii. Bushnell writes } \\
\text { "The carved surfaces of both specimens were } \\
\text { originally covered with a thin layer of yellow } \\
\text { gold, the greater portion of which still adheres, } \\
\text { although on the higher, more exposed parts of } \\
\text { the relief, it has been rubbed or worn away." } \\
\text { These specimens are now preserved in the } \\
\text { Museo Nazionale d' Antropologia ed Etnologia } \\
\text { del R. Instituto di Studi Superiori in Florence. } \\
\text { There is another specimen, equally richly carved } \\
\text { and covered with gold, in the Kircheriana } \\
\text { Museum in Rome. } \\
57 \text {. Fray Juan de Torquemada, Segunda } \\
\text { Parte de los Veinte i Un Libros Rituales i } \\
\text { Monarchia Indiana, lib. III, cap. xxxiv, p. 487, } \\
\text { 2d ed., Madrid, 1723. } \\
58 \text {. Fray Bernardino de Sahagun, Historia }\end{array}$ \\
\hline & I N I A N NOTES \\
\hline
\end{tabular}




\section{NOTES}

General de las Cosas de Nueva España que en Doce Libros y Dos Volumenes escribió el R. P. Fr. Bernardino de Sahagun, published by Carlos María de Bustamante, tomo II, lib. IX, cap. xv, p. 387, Mexico, 1829. Also published by Lord Kingsborough, op. cit., vol. v, chap. $\mathrm{i}$-xl, of the sixth book, pp. 346-493. Vol. vi, 464 pp. (London, 1831), contains books one to five, chapters xli-xliii of the sixth book, and books seven to twelve.

59. Eduard Seler, L' Orfèverie des Anciens Mexicains et leur Art de Travailler la Pierre et de Faire des Ornements en Plumes, Compte rendu de la VIIIeme Session du Congrès International des Américanistes, Paris, 1890, pp. 401-452. The chapter on the goldsmiths is on pp. 401-418. This paper, with slight changes in the French translation of the Nahuatl text, and some revision, is included in his Gesammelte Abhandlungen zur Amerikanischen Sprachund Alterthumskunde, zweiter Band, Berlin, 1904, pp. 620-634. In his introduction Seler writes: "It is a well established fact that the arts and industries of ancient Mexico had come to a high degree of perfection. The historians of the Conquest are full of admiration for the works that Mexican gold-workers executed, as well as the stone workers, the jewelers and the artisans of featherwork. In order to be convinced of the justice of their commendation, it is enough to examine the long list of objects enumerated in the "Memoria de los plumajes $y$ joyas que se envian á España para dar y repartir á las iglesias é monasterios é personas particulares siguientes" (Colección de Documentos Ineditos del

\section{A N D MONOGRAPHS}




\begin{tabular}{|c|c|}
\hline 216 & G OLDSM I TH'S A R T \\
\hline & $\begin{array}{l}\text { Archivo General de Indias, t. xII, pp. 318, 345), } \\
\text { objects that the conquerors thought worthy of } \\
\text { consideration by the side of the ornaments with } \\
\text { which they covered the images of the saints } \\
\text { and the rich vestments of the priests of the } \\
\text { Church. } \\
\text { "Unfortunately, there remain to us but } \\
\text { very few of these masterpieces. As to the } \\
\text { gold objects, they were sent to the melting pot. } \\
\text { The coats of feathers and the round shields } \\
\text { were lost, ruined by vermin. There are only } \\
\text { the objects worked in polished stone which have } \\
\text { been saved in any considerable quantity. } \\
\text { "Up to the present, we know very little } \\
\text { about the methods of working employed by } \\
\text { these artisans. As these professions continued } \\
\text { during the first century which followed the } \\
\text { conquest, the historians, for the most part. } \\
\text { did not take the trouble of going into detail } \\
\text { with the subject. They refer the reader to } \\
\text { the artisans themselves and not to their work. } \\
\text { Among the articles that Father Sahagun col- } \\
\text { lected, there are three chapters which treat of } \\
\text { technical subjects. But the venerable priest } \\
\text { has not wished to make a translation of it } \\
\text { because 'the contents of this chapter have no } \\
\text { connection with the Faith, and do not bear on } \\
\text { IIorality in any way.' } \\
\text { "In the month of May in the year } 1890 \text {, } \\
\text { I was permitted, thanks to the kindness and } \\
\text { obligingness of competent authorities, to study } \\
\text { the two fragmentary manuscripts of the orig- } \\
\text { inal text in Aztec of the work of Father Sahagun. } \\
\text { which were preserved in the libraries of Madrid. } \\
\text { I profited by this occasion by making an exact } \\
\text { copy of the three following chapters. They }\end{array}$ \\
\hline & I N I A N NOTES \\
\hline
\end{tabular}




\begin{tabular}{|c|c|}
\hline NOTES & 217 \\
\hline $\begin{array}{l}\text { constituted a part of the Manuscrit de l' Aca- } \\
\text { démie de l' Histoire, a manuscript which forms } \\
\text { the second half of the work of Father Sahagun } \\
\text { from the eighth book. The first of these } \\
\text { chapters, corresponding to the sixteenth chap- } \\
\text { ter of the ninth book of the Spanish edition, } \\
\text { commences on the second page of folio } 44 \text { of } \\
\text { said manuscript. } \\
60 \text {. Sahagun, op. cit., tomo II, cap. vi, pp. } \\
\text { 388-389. } \\
\text { 61. Arqueologia Zapoteca, Memoria leida } \\
\text { por el Dr Nicolas Leon en la Sociedad Mexicana } \\
\text { de Geografia y Estadistica (Separate edition, } \\
18 \text { pages, pl.), Mexico, } 1900 \text {. } \\
62 \text {. It may be well to record here a state- } \\
\text { ment regarding gilding, which thus far has } \\
\text { never been verified. If it were true, a very } \\
\text { important trade secret has been lost. Oviedo } \\
\text { y Valdés (Historia General y Natural de } \\
\text { Indias, t. I, lib. vI, cap. viii, p. 189, Madrid, } \\
\text { 1851), in writing about the natives of Central } \\
\text { America, states that they knew how to "gild } \\
\text { the pieces or things which they worked from } \\
\text { copper and very base gold, in a manner resemb- } \\
\text { ling gold of } 23 \text { carats." This color was im- } \\
\text { parted by means of certain herbs, which pro- } \\
\text { cess they kept a secret from the Spaniards, } \\
\text { although Oviedo further remarks that he madc } \\
\text { repeated attempts to induce the Indians to } \\
\text { tell him the secret of this gilding, which they } \\
\text { refused to do. } \\
\text { Martinez Gracida believes that gilding was } \\
\text { accomplished by the use of quicksilver. He } \\
\text { writes: "Gilding, according to reports brought } \\
\text { together from lost traditions, seems to have }\end{array}$ & \\
\hline A N I MONOGRAPHS & \\
\hline
\end{tabular}




\begin{tabular}{|c|c|}
\hline 218 & GOLDSMITH'S ART \\
\hline & 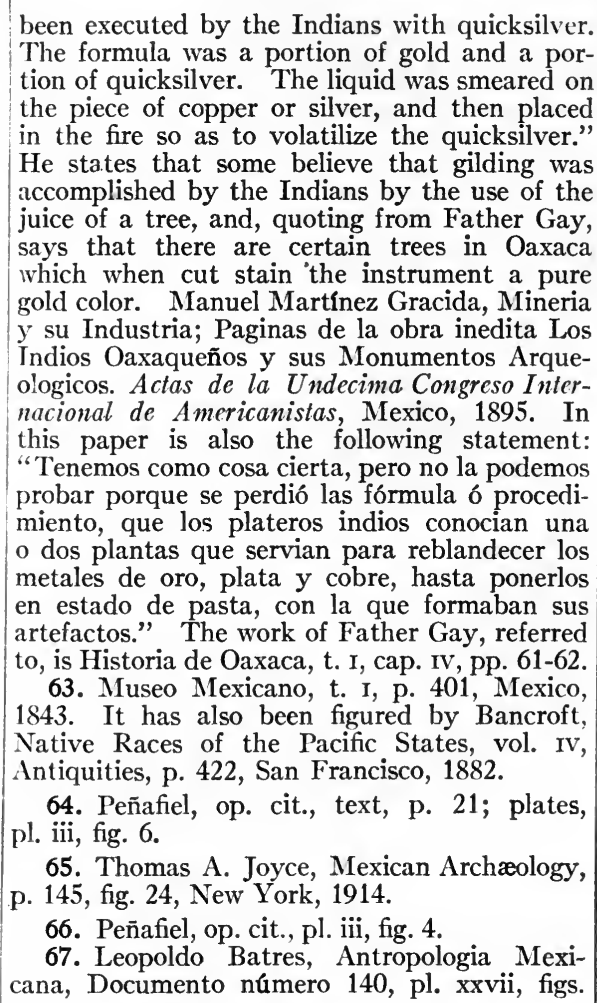 \\
\hline & I N D I N NOTES \\
\hline
\end{tabular}


9,10. This work is an appendix to the Memoria que el Secretario de Justicia é Instrucción Publica Licenciado Joaquin Baranda presenta al Congreso de la Union, Mexico, 1889.

68. Teobert Maler, Découverte d' un Tombeau Royal Zapotéque, á Tehuantepec en 1875, La Nature, Paris, June 24, 1879. pp. 22-24. The illustrations have been copied by Nadaillac in his Prehistoric America, New York, 1890, pp. 369, 371.

69. Alfredo Chavero, México a Traves de los Siglos, t. I, p. 407, Mexico, Barcelona, 1887.

70. Joyce, op. cit. pl. xi, fig. 5; also Chavero, op. cit., p. 408.

71. These two pieces are also illustrated by Chaveró, op. cit., pp. 407-408. Our plate vi, $a$, has also been illustrated in colors by Peñafiel, op. cit., pl. 113.

72. See Peñafiel, op. cit., pl. iii, fig. 8 .

73. Batres, op. cit., pl. xxvii, fig. 4 ; also Peñafiel, op. cit., pl. iii, fig. 3.

74. Francisco del Paso y Troncoso, Escritura Pictórica. Codice Kingsborough, lo que nos Enseña. Proceedings of the Eighteenth International Congress of $\cdot$ Americanists, London, 1912, pp. 455-460, pl. Troncoso describes the contents as follows: "It is a memorial or statement by the native inhabitants of Tepetlaoztoc (a small hill-town between Tetzcoco and Otumba) of the extortionate tribute exacted, and the ill-treatment suffered under the Spanish masters to whom successively they had been assigned by the King of Spain."

75. In the sale catalog of the Wilkinson col-

\section{A N D MONOGRAPHS}

I. N. M. -2 


\begin{tabular}{|c|c|}
\hline 220 & GOLDSMITH'S ART \\
\hline & $\begin{array}{l}\text { lection of Mexican books in } 1914 \text { a copy of the } \\
\text { Gates reproduction is thus described: "Codex } \\
\text { Tepeztlaustuc. A Mexican picture ms. with } \\
\text { portraits of many of the Conquistadores, the } \\
\text { native chief men, the exactions imposed, } \\
\text { jewels, feather ornaments, mantles, etc., build- } \\
\text { ings erected, and various historical matter. } \\
\text { Folio, pp. 140. This work is probably one of } \\
\text { the most beautifully executed pieces of work } \\
\text { that have come down to us; dating from the } \\
\text { period immediately following the Conquest, } \\
\text { the technical execution is beyond praise. The } \\
\text { illustrations are accompanied by a text in } \\
\text { Spanish, in an exquisite hand, giving the names } \\
\text { of the personages and the entire story of the } \\
\text { incidents related." This copy was purchased } \\
\text { by the Hispanic Society of America. There is } \\
\text { another copy in the library of Peabody Museum, } \\
\text { Harvard University. } \\
76 \text {. Le6n Pinelo, Biblioteca Occidental, t. II, } \\
\text { titulo xiv, p. 700, 2d ed., Madrid, 1738. } \\
77 \text {. Kingsborough, op. cit., vol. I, pl. 68, } \\
\text { no. 28. } \\
78 \text {. Ibid., pl. 48, nos. } 24,25 \text {. } \\
79 \text {. This figure has been published by Seler } \\
\text { in Die Mexikanischen, Bilderhandschriften } \\
\text { Alexander von Humboldt's in der Kgl. Biblio- } \\
\text { thek zu Berlin, Berlin, 1893. A translation } \\
\text { has appeared in Bulletin } 28 \text { of the Bureau of } \\
\text { American Ethnology, Washington: The Mexican } \\
\text { Picture Writings of Alexander von Humboldt } \\
\text { in the Royal Library at Berlin. The drawing } \\
\text { is Fragment III, pl. viII, of the Bureau publica- } \\
\text { tion. The original painting on maguey paper } \\
\text { was formerly a part of the Boturini collection. }\end{array}$ \\
\hline & INDIAN NOTES \\
\hline
\end{tabular}




\section{NOTES}

80. Peñafiel, Indumentaria Antigua Mexicana, Mexico, 1903, pl. 15, 4b.

81. For more detailed information concerning Mexican shields the reader is referred to the paper by Mrs Zelia Nuttall on "Ancient Mexican Shields," published in Internationales Archiv für Ethnographie, Bd. v, Leiden, 1892; also to Ferdinand von Hochstetter's memoir, "Ueber Mexikanischen Reliquien aus der Zeit Montezuma's in der K. K. Ambraser Sammlung," Separatabdruck aus dem xxxv Bande der Denkschriften der Philosophisch-Historischen Classe der Kaiserlichen Akademie der Wissenschaften, Wien, 1884, pl. iv.

82. The Book of the Life of the Ancient Mexicans, Containing an Account of their Rites and Superstitions, an Anonymous Hispano-Mexican Manuscript Preserved at the Biblioteca Nazionale Centrale, Florence, Italy, Reproduced in Facsimile with Introduction, Translation, and Commentary, by Zelia Nuttall. Part I, introduction and facsimile, Berkeley, 1903.

83. Codex Magliabecchiano XIII. 3. Manuscrit Mexicain Post-Colombien de la Biblioteca Nazionale de Fैlorence reproduit en photochromographie aux frais du Duc de Loubat, Rome, 1904.

84. George Byron Gordon, "The Serpent Motive in the Ancient Art of Central America and Mexico," reprinted from Transactions, Department of Archaology, University of Pennsylvania, vol. I, part iii, Philadelphia, 1905, pl. xvi-xvii.

\section{A ND MONOGRAPHS}




\begin{tabular}{|c|c|}
\hline 222 & GOLDSMITH'S A R T \\
\hline & $\begin{array}{l}\text { 85. See paper by the writer, "The Cruciform } \\
\text { Tombs of Mitla and Vicinity," Putnam Anni- } \\
\text { versary Volume, New York, 1909. } \\
\text { 86. Peñafiel, Monumentos del Arte Mexi- } \\
\text { cano Antiguo, pl. III, fig. 5. Batres, op. cit., } \\
\text { pl. xxvii, fig. 5. } \\
\text { 87. Leó, op. cit., fig. 3a. } \\
\text { 88. Records of the Past, vol. virr, parts 3, 4, } \\
\text { May-June, July-Aug., 1909. } \\
\text { 89. Peñafiel, op. cit., pl. 111, fig. 7. Leon, } \\
\text { op. cit., fig. 10a. } \\
\text { 90. Peñafiel, op. cit., pl. 111, fig. } 7 \text { (central } \\
\text { figure). } \\
\text { 91. This specimen was collected by Hermann } \\
\text { Strebel, and has been described and illustrated } \\
\text { by him in Alt-Mexiko, first part, p. 51, and } \\
\text { pl. xvi, fig. 7, Hamburg und Leipzig, 1885. } \\
\text { This site is just north of the road taken by } \\
\text { Cortes in his march from Vera Cruz to the } \\
\text { present city of Jalapa. Our illustration is } \\
\text { from a photograph furnished by Professor Seler. } \\
\text { 92. Peñafiel, op. cit., pl. 111, fig. } 9 \text {. } \\
\text { 93. In the Lienzo de Tlaxcalla we find many } \\
\text { warriors wearing the eagle insignia. See Anti- } \\
\text { güedades Mexicanas, published by the Junta } \\
\text { Colombina, Mexico, 1892. Tobar, the author } \\
\text { of Codice Ramirez, published by Vigil in his } \\
\text { Biblioteca Mexicana, in the same volume with } \\
\text { the Cronica Mexicana of Tezozomoc, in de- } \\
\text { scribing events under the reign of Montezuma, } \\
\text { states, "There was another order of caballeros } \\
\text { (knights), who were called the eagles, and } \\
\text { another called the lions or tigers; they were } \\
\text { allowed to wear garments and cloaks of cotton }\end{array}$ \\
\hline & INDIAN NOTES \\
\hline
\end{tabular}




\section{NOTES}

richly worked and decorated, and jewels of gold and silver." (p. 87.)

94. Two specimens of this type are illustrated by León, op. cit., pl. 11a, 12a.

95. Gay, op. cit., vol. I, cap. iv, p. 62.

96. Notes on Some Mexican Relics, Archeological Report for 1900, Toronto.

97. Peñafiel, op. cit., p. 20.

98. Bernal Díaz, op. cit., t. II, cap. xcii, pp. 79-80.

99. Leopoldo Batres, Excavaciones en la Calle de las Escalerillas, Mexico, 1900, pp. 22-23.

100. Eduard Seler, "Die Ausgrabungen an Orte des Haupttempels in Mexico" (Sonderabdruck aus Band xxxI [Der Dritten Folge Band I] der Mittheilungen der Anthropologischen Gesellschaft in Wien), Vienna, 1901, p. 137. Also translated into Spanish, "Las Excavaciones en el Sitio del Templo Mayor de Mexico," Anales del Museo Nacional de Mexico, tomo vir, entrega 8, March, 1902, pp. 255-256.

101. Codice Ramírez, op. cit. (see note 93), pl. 21.

102. Francisco Plancarte, "Archeologic Explorations in Michoacan, Mexico," American Anthropologist, vol. vi, Jan. 1893, pp. 79-84.

103. Carl Lumholtz, Unknown Mexico, vol. II, p. 295, New York, 1902.

104. Ibid., pp. 295-299; pl. vii is a beautiful reproduction in colors of this remarkable specimen.

105. Marshall H. Saville, "The Glazed Ware

\section{A N D M ONOGRAPHS}




\begin{tabular}{|c|c|}
\hline 224 & GOLDSMITH'S ART \\
\hline & $\begin{array}{l}\text { of Central America," etc., Holmes Anniversary } \\
\text { Volume, Washington, 1916, pp. 421-426, pl. } \\
\text { i-ii. } \\
\text { 106. E. T. Hamy, "La Dent d' Or de } \\
\text { Tepito," Decades Americanæ, Paris, n. d., } \\
\text { pp. 161-162, figs. 79-80. } \\
\text { 107. Papantla or Tajin is the most important } \\
\text { known group of ruins in the state of Vera Cruz. } \\
\text { Unfortunately no investigations have been } \\
\text { carried on at this site. } \\
\text { 108. This important specimen has been } \\
\text { illustrated by Peñafiel, Monumentos del Arte } \\
\text { Mexicano Antiguo, pl. 112. } \\
\text { 109. Since this monograph was in type the } \\
\text { University Museum of Philadelphia has placed } \\
\text { on exhibition a number of gold objects from } \\
\text { Mexico. One of these is the gold ring men- } \\
\text { tioned on p. 147 and illustrated on pl. III, } f . \\
\text { Another piece is a labret representing the head } \\
\text { of a crested eagle, which has been figured by } \\
\text { Peñafiel, pl. 111, 1-2, of his Monumentos del } \\
\text { Arte Mexicana Antiguo. A gold bell, formerly } \\
\text { in the possession of Sr Antonio Rolleri, figured } \\
\text { by Peñafiel (ibid., pl. 114), has likewise been } \\
\text { acquired by the University Museum. There is } \\
\text { also a small gold ring like the one given in our } \\
\text { pl. mI, } e \text {, which lacks the upper decoration. In } \\
\text { the collection are eight small gold bells, and } \\
\text { four others of a larger size, one of which is sim- } \\
\text { ilar to our pl. xvmI, } c \text {. Finally, there is a large } \\
\text { fragment, seemingly of silver, bearing a human } \\
\text { head projecting from the upper part; it is char- } \\
\text { acterized by a long nose, and various parts of } \\
\text { the face are outlined with broad gold bands, } \\
\text { while the mouth contains a portion of a mosaic }\end{array}$ \\
\hline & INDIAN NOTES \\
\hline
\end{tabular}


of turquoise, and shell inlays are found in places. This fragment may well be the central feature of one of the numerous shields sent to Spain by Cortés, mentioned in the inventories. There is also a gold bell somewhat like the bell figured in our pl. $\mathrm{xv}, b$.

110. Through inadvertence the following paragraph was omitted in translating this inventory:

For the Lords Officials of the Casa de Contratación (House of Trade)

Item: three shields, one, the field blue and a serpent in the middle, and [a] red feather in the middle; another, the field green, and another serpent of gold and blue; the other, the field blue and a red serpent of feathers and gold in the middle.

\section{A N D MONOGRAPHS}





\section{INDEX}

Achintla, gold object from, 172

Acocospa, tribute paid by, 109

Acuitlapan, tribute paid by, 109

Adarmes of silver, 30

Admiral of Castilla, gifts to, 62

Adrian VI addressed by Peter Martyr, 195

Age of gold objects, 8

Aguilar, Alonso de, see Aguilar, Francisco de

Aguilar, Francisco de, on Aztec treasure, 42-43;

on gold and silver wheels, 35; on Spanish

loot, 193; on the gold disc, 37

Alabaster, pitchers of, 17

Alaminos, a pilot, 195

Alaras, Anton de, gold taken by, 91

Alba, Duke of, gifts to, 65

Albornoz, Rodrigo de, paymaster, 97

Alcarrazas of gold, 70

Alderete, Julian, King's proctor, 86, 87, 96

Alfaro, Luis Hernandes de, gold consigned to, 89,90

Alloys made by Aztecs, 134

Alonso, Domingo, shipmaster, 209

Alum used in gold-working, 132, 140-142

Amazons, report of 18-19

Amber, labrets of, $71,112,113$

American Museum of Natural History, gold objects in, $150,170,171,173,174,181$

\section{A ND MONOGRAPHS}




\begin{tabular}{|c|c|}
\hline 228 & GOLDSMITH'S A R T \\
\hline , & 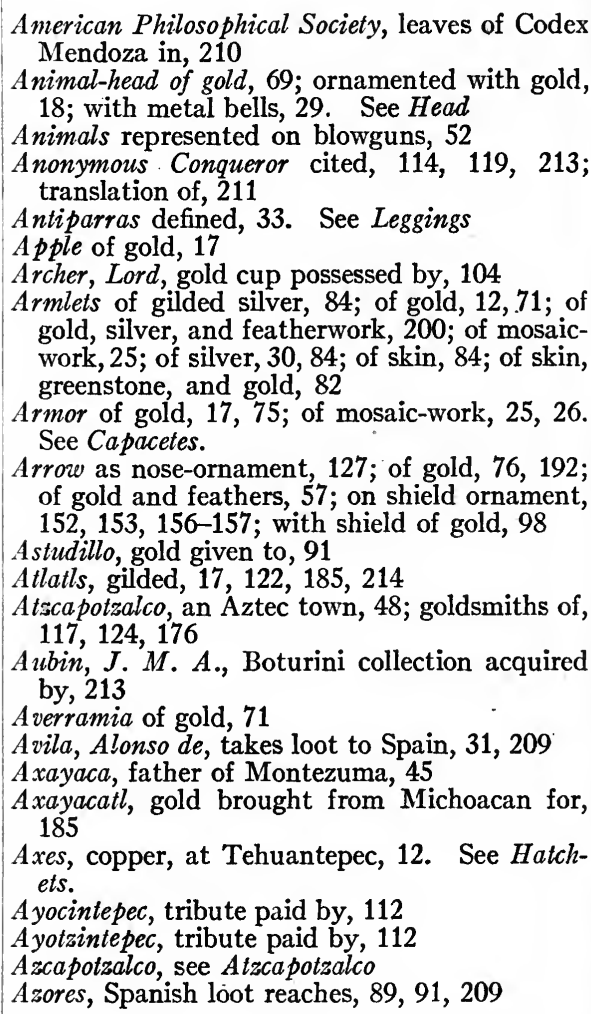 \\
\hline & INDIAN NOTES \\
\hline
\end{tabular}




\section{N D E X}

Baeza, Governor, gift to, 66

Bags sent to King, 97, 100; used in trade, 19. See Pouch

Bancroft, $H$. $H$., cited, 218

Baranda, Joaquin, cited, 219

Barcia, A. Gonzales, edition of Herrera by, 211

Batres, Leopoldo, cited, 150, 164, 179, 218, 219, 223

Beads, clay, with gold-leaf, 17; glass, used in trade, 12, 19; gold, crown of, 14; of gilded wood, 16; of gold, $13,16,17,71,85,100$, $145,170,173,181$; of gold on armor, 26; of gold on head-piece, 29; of jadeite on idols, 180; of stone found in tomb, 147; on gold flowers, 70; on gold necklace, 67, 68; on gold object, 174; represented in codex, 108, 112; sent to King, 97; with gilding, 182. See Rosary

Beards represented on idol, 186

Beçotes, see Lip-ornaments

Bee of gold on shield, 63

Bells as ear-ornaments, 69; as ring pendants, 145; Aztec name for, 213; beads used as, 101; in form of monkey-head, 172; of gold, 12, $16,23,25,26,29,38-39,76,115,168,170$, 181, 183, 184, 196-198, 203, 204, 224 ; of turquoise in Aztec poetry, 116; on eaglehead ornament, 149; on gold collars, 129; on gold jewel, 148-150; on shield ornament, 152, 156 ; represented in codex, 108, 112; with beads, 98

Benavides, Alonso de, gold taken by, 89

Berendt, C. H., drawings of gold objects by, 146, 163,164

Berlin Museum, gold objects in, 149, 169, 174

\section{AND MONOGRAPHS}




\begin{tabular}{|c|c|}
\hline 230 & GOLDSMITH'S ART \\
\hline ' & 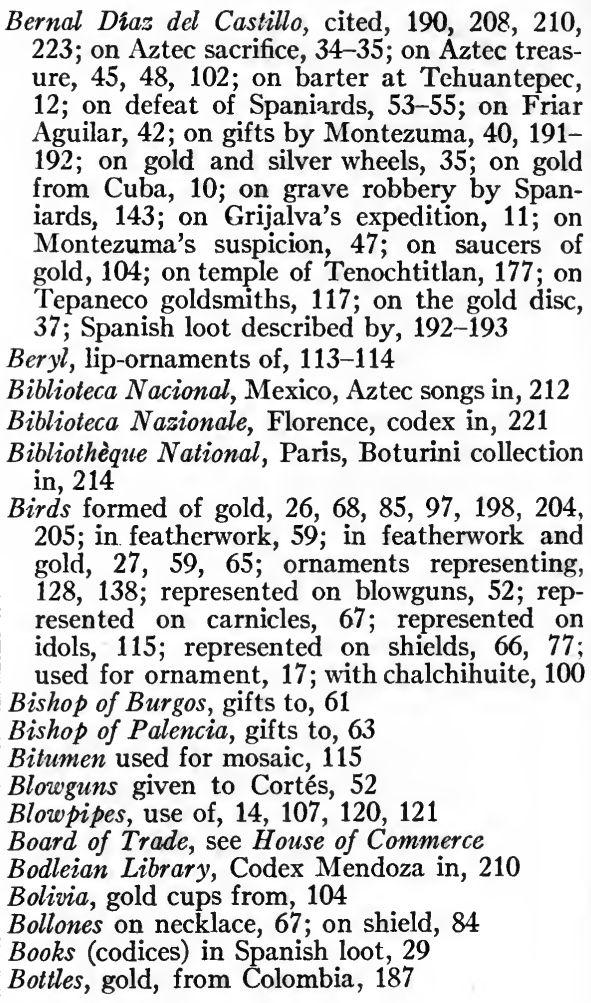 \\
\hline & INDIAN NOTES \\
\hline
\end{tabular}


Boturini collection cited, 213, 220

Bowl, decorated, from Texcoco, 162. See Pottery Bows of gold sent to Spain, 192

$B o x$ of leather and featherwork, 24

Bracelets, Aztec name for, 213; of gold, 12, 15, $71,85,198,204$; with eagle-claws, 82

Brasseur de Bourbourg, Aztec song copied by, 212 Brazales, see Wristguards

Breast-ornaments of gold, 175, 180, 183; on idols, 186

Brinton, D. G., cited, 116; on ancient Nahuatl poetry, 211; on existence of certain codex, 155

British Columbia, labrets worn in, 173

British Museum, copy of Codex Kingsborough presented to, 154; Mexican manuscripts in, 153

Bronze age of Europe, 7

Bronse objects of Middle America, 7

Brooch, gold, found in tomb, 151

Bucklers of gold, 198

Bugle presented to King, 79, 99

Burgos, castle of, compared with Mexican fort, 106; certification of gold objects at, 102 . See Crucificio of Burgos

Bushnell, D. I., Jr., cited, 214

Buskins among Spanish loot, 12, 197

Bustamante, C. M. de, cited, 123-125, 215; edition of Sahagun by, 207

Butterflies as ear-ornaments, 69 ; nose-ornaments in form of, 181; of gold, 58, 83; of gold, stone, and shell, 70, 83; ornaments in form of, 98, 150 ; represented on head-crest, 78; represented on shield, 63,76

Buttons, blue, on chasuble, 58; of gold, 123

\section{A N D MONOGRAPHS}




\begin{tabular}{|c|c|}
\hline 232 & GOLDSMITH'S ART \\
\hline 。 & 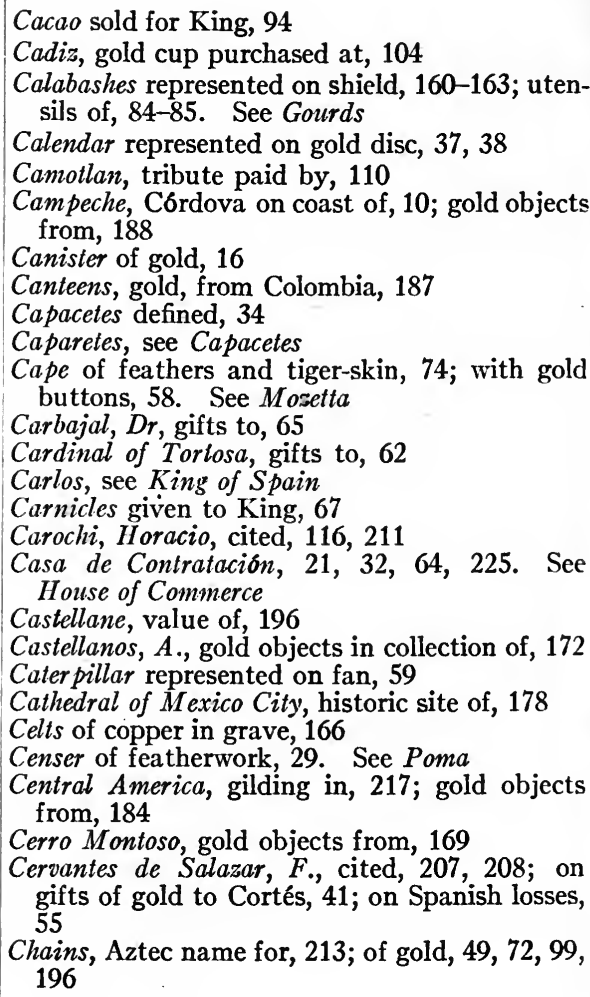 \\
\hline & INDIAN NOTES \\
\hline
\end{tabular}


Chalchihuite, medals ornamented with, 72; offered to Tenochtitlan temple, 177; on lion ornament, 98; on mirror, 67 ; set in ornaments, 98-101; ornaments of, 46, 68-69; shell ornamented with, 70

Chapel of Sant Elifonso, gifts to, 57

Charcoal used in gold-working, 126-131, 137, 140, 142

Charles V, loot received by, 32. See King of Spain

Chasubles of featherwork, 57-59

Chavero, Alfredo, cited, 213, 219; gold objects described by, 148-149

Chiapas, source of gold tribute, 113

Chichen Itza, gold objects from, 189

Chimalli, the Mexican shield, 152

Chinantecs, gold from land of, 105

Chinantlan, tribute paid by, 112

Chipetlan, tribute paid by, 109

Chiriqui, gold objects from, 169, 181, 187

Cholula, Cortés at, 40; pottery from, 184; seat of Quetzalcoatl, 117

Churches, gifts to, 57-60

Cicadas formed of gold 68; made of feathers, 62; of gold in necklace, 68; of gold on shield, 65, 66 ; of gold with rosary, 98; with chalchihuites and turquoise, 100

Cimeras, see Helmets

Clavigero, F. X., cited, 206; on Spanish loot, 204 Clay used in gold-working, 126, 129, 136, 139, 142

Clayton, Thomas, gold objects purchased by, 148 Clothing of cotton in Spanish loot, 30-31. See Cotton; Garments

Coatelicamat, ruler of Culua, 106-107

\section{A N D MONOGRAPHS}




\begin{tabular}{|c|c|}
\hline 234 & GOLDSM ITH'S A R T \\
\hline , & 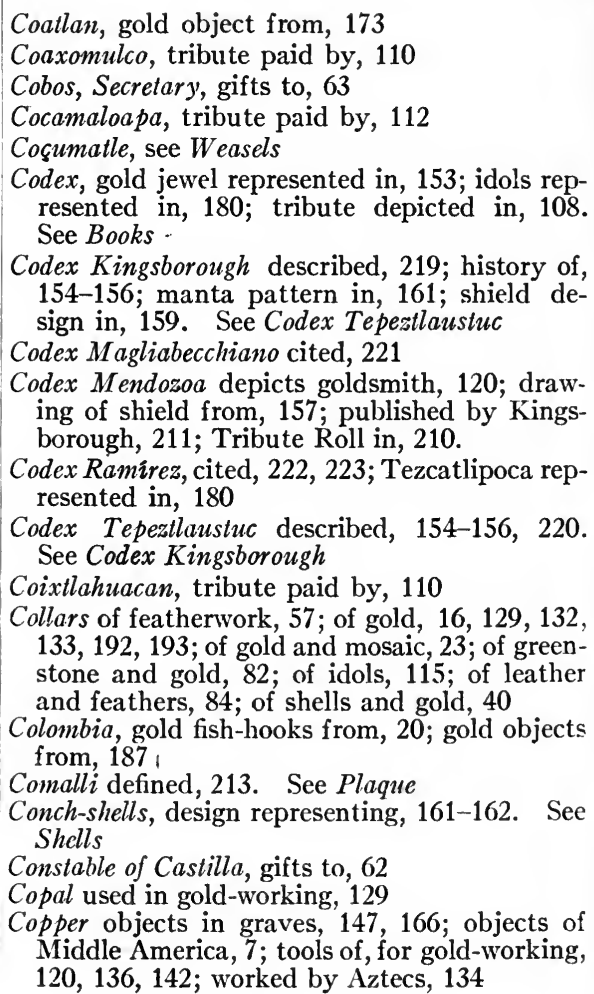 \\
\hline & INDIAN NOTES \\
\hline
\end{tabular}


Cordoba, F. H. de, expedition of, 9, 10; paper on, 190

Córdova, Juan de, gold consigned to, 89, 90

Corn represented in featherwork, 57

Cornstalk sent to King, 74

Corselet given Grijalva, 12; gold embroidered, 59; of feathers and gold, 56; of gold armor, 75, 79

Cortés, Hernán, atlatls sent to Spain by, 122; certification by, 96; examines Aztec treasure, 45-47; expedition of, 20; gold gathered for, 102, 103; gold objects given to, by Montezuma, 40, 193; gold treasure stamped by, 49; informed of saucers of gold, 104; inventory signed by, 66; jewels registered by, 97 ; letters of, cited, 206, 208, 210, 211; loot received by, 195; objects sent to King by, 31, 79-88, 202; on defeat of Spaniards, 55; on Montezuma's treasure, $35,41-42,50-53,119$; on source of gold, 105; on Tenochtitlan market, 119; on the Royal fifths, 22; route from Vera Cruz to Jalapa, 222; shields obtained by, 85; shields sent to King by, 95, 159; wheels of gold and silver given to, 35

Cortés Society, publications of, cited, 190, 211

Costa Rica, gold objects, from, 169, 181

Cotastla identified with Cuetlaxtla, 20

Cotton, cloth of, presented to Cortés, 52; cloth of, sent to King, 85; garments, 18, 30-31, 44, 205, 206; garments of gold and, 198-200; garments of, insignia of knights, 222; mantles made of, 18; sold for King, 94; woven with double woof, 34

Coyoacan, see Cuyoacan

Coyollapan, tribute paid by, 110

Coyolli defined, 213

\section{A N D MONOGRAPH S}




\begin{tabular}{|c|c|}
\hline 236 & GOLDSMITH'S ART \\
\hline & 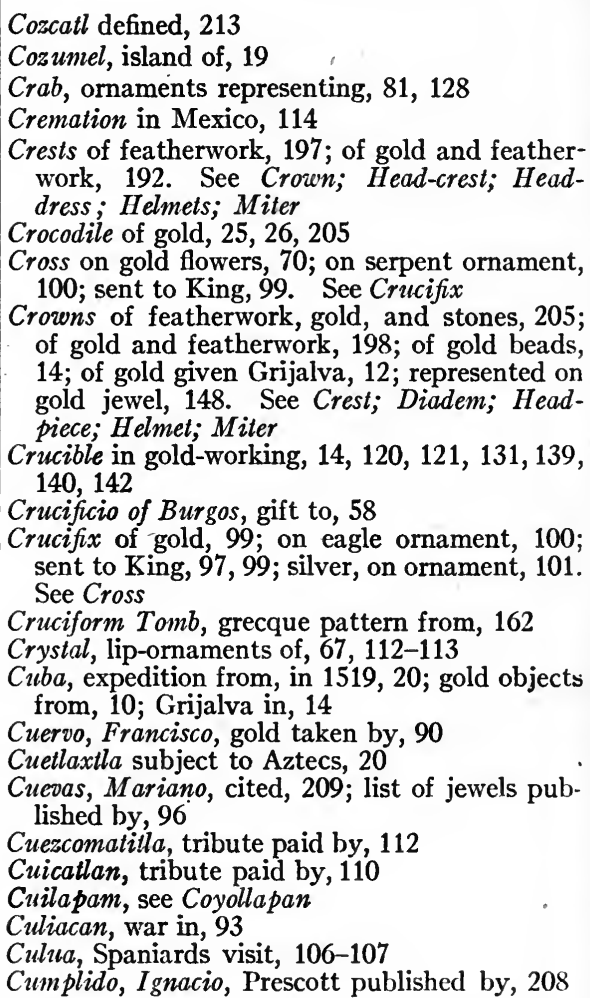 \\
\hline & INDIAN NOTES \\
\hline
\end{tabular}


Cups of gold, 16, 44, 99, 103-104

Cuyoacan, certificate of objects executed at, 86,96

Cuzula, gold from, 105-106

Dávila, Alonso, King's proctor, 49, 53, 72, 86, $87,90,91$

Death's figure of greenstone and gold, 81

Death's head of gold, 69. See $S k u l l$

Deer of gold, 192-193

Decrskin among Spanish loot, 29, 200; leggings trimmed with, 23; shoes of gold and, 198

Designs, how applied to ornaments, 135; on Mexican shields, 156-160

Diadems of gold, 11, 13; represented in codex, 108, 112. See Crest

Diaz, Juan, cited, 190; on gold among Sacrificios islanders, 13; on Grijalva's expedition, 11

Dienz, Diego, loot examined by, 36, 191, 193

Discs of gold, 24, 70, 151, 180,181; of gold and silver, 200; of gold, Aztec name for, 213; of precious stones, 194; represented in codex, 109. See Wheels

Dog-head of mosaic, 18

Doña Juana, see Queen of Spain

Doñate, see Oñate

Doorman, Agustin, rings in possession of, 145

Doublet of colored feathers, 18. See Garments Dragon represented in gold, 193. See Monsters Drums of silver in Aztec poetry, 116; sent to King, 79

Duck-head of gold and greenstone, 81

Ducks of feathers and gold, 58; of gold, 11, 70, $71,192,198,205$; of gold in Cuba, 10

\section{A ND MONOGRAPHS}




\begin{tabular}{|c|c|}
\hline 238 & GOLDSMITH'S A RT \\
\hline & 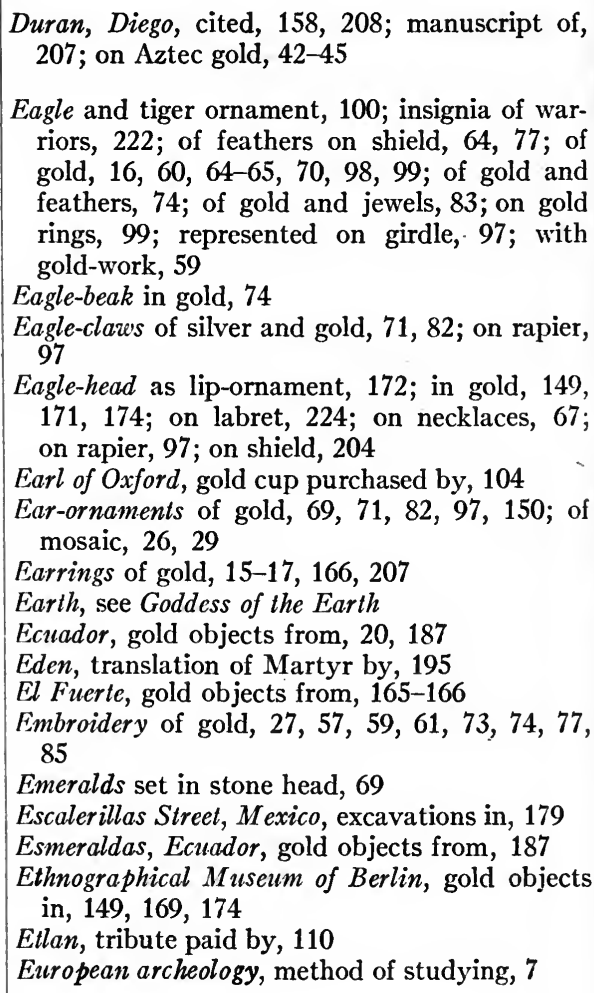 \\
\hline & INDIAN NOTES \\
\hline
\end{tabular}


Face of chalchihuite, 84 ; of greenstone, 83

Fans of featherwork, 27, 29, 66, 197, 205; of feathers and embroidery, 58; of feathers and gold, 17, 24, 28, 58, 59, 78, 200; of featherwork and turtle-bone, 78; of gold, 192; of tortoise-shell, 60 ; with flowers and embroidery, 57; with gold idol, 15 . See Mosqueador Feathers, see Quills

Featherwork among Spanish loot, 24, 51-52, 72$76,197,202$; box made of, 24; destruction of, 216; of ancient Mexico, 189; on garments, $18,23,199,200$; on golden snake, 194; on rods, 34 ; on shields, $17,103,158,159$; represented in codex, 154; various objects of, 2431, 56-85, 205

Feather-workers, designs for metal made by, 135

Fernaindes, Vicente, gold taken by, 91

Figueroa, graves robbed of jewels by, 143

Filigree, gold and silver, 189; objects of, 149, $164,169,171,174,186$

Finger-rings found in tomb, 145 . See Rings

Fish, how made in metal, 121; of gold, 34, 97-99,

128, 198, 205

Fish-hooks of gold, 16, 19-20, 191

Florence, Italy, Mexican. codex in, 160

Flowers of chalchihuite, 68 ; of gold, 57, 70, 82, $129,138,196$; of gold and silver, 70 ; of snailshells, 71; of stone, 70; of stone and gold, 81; represented on blowguns, 52

Flutes of gold, 68

Fonseca, Antonio de, gifts to, 65

Forsyth, L. M. N., on gold objects, 165-168

Frog of gold, 16, 173, 201

Funeral-urns, symbols on, 172

\section{A N D MONOGRAPHS}




\begin{tabular}{|c|c|}
\hline 240 & GOLDSMITH'S ART \\
\hline & $\begin{array}{l}\text { Gallego, Pedro, gold taken by, } 91 \\
\text { Garments, cotton, insignia of knights, 222; gold- } \\
\text { en, in Aztec poetry, 117; of cotton and gold, } \\
\text { 198-200; of feathers, 159; of tiger-skin, 72, } \\
74 ; \text { represented in codex, 161; sent to King, } \\
79 ; \text { used in trade, } 19 \\
\text { Gates, W. E., on Codex Tepeztlaustuc, 154-155, } \\
\text { 220. } \\
\text { Gay, Father, cited, 175, 218, 223 } \\
\text { Gayangos, Pascual de, cited, 206, 207, 209 } \\
\text { Geological stratification, European archeology } \\
\text { based on, } 7 \\
\text { Gilding in Central America, 217; of atlatls, 122; } \\
\text { of beads, 16. See Leaf-gold } \\
\text { Girdles of featherwork, 197; of idols, 115; sent } \\
\text { to King, 99; with ornaments, 97, 101. See } \\
\text { Clothing; Garments } \\
\text { Girls, Indian, sent to Spain, 32 } \\
\text { Glass objects used in trade, 19 } \\
\text { Gloves of tanned skin, 29, 34 } \\
\text { Goalteca heads on rings, } 99 \\
\text { Goddess of the Earth, nose-ornament of, 181 } \\
\text { God of Pulque, nose-ornament of, 181 } \\
\text { Gold-leaf, see Leaf-gold } \\
\text { Gomara, F. L. de, cited, 191; on Aztec jewels, 38- } \\
\text { 39; Spanish loot described by, 15-19, 191-192, } \\
\text { 202-206 } \\
\text { Gordon, G. B., cited, 162, 221 } \\
\text { Goupil, Boturini collection acquired by, 213 } \\
\text { Gourds, common use of, 160; designs of, in co- } \\
\text { dex, 160-162; for collecting gold, 105; gold- } \\
\text { dust kept in, 108-110. See Calabashes } \\
\text { Gracida, Martinez, on ancient gilding, 217-218 } \\
\text { Grado, Alonso de, sends loot to Spain, 31, 79- } \\
\text { 86, } 96\end{array}$ \\
\hline & I NDIAN NOTES \\
\hline
\end{tabular}




\section{N D E X}

Granada, Archbishop of, letter on Spanish loot written to, 194

Graves, gold objects found in, 170, 172, 173, 175, 183; near Pueblo Viejo, 167; robbed by Spaniards, 143. See Tomb

Grecque pattern in Mexico, 161-163

Greenstones among Spanish loot, 196; as jewels, 23; heads made of, 69-70; human face of, 69; on gold necklaces, 38, 39; ornaments of, 69, 81,98

Greyhounds, collars for, 84; turquoise necklace for, 71

Griddle, clay, Aztec name for, 213

Grijalva, Juan de, barter obtained by, 207; exploration by, 10, 19, 190; gold objects given to, 11; report of, on gold objects, 14-19, 202

Guadalupe, see Our Lady of Guadalupe

Guarique defined, 206-207; of unknown meaning, 34

Guascaza in Spanish loot, 31

Guatêmoc, interview with, 178

Guaxteca figure on mirror, 67

Guerrero, gold from, 105

Guzman, Cristobal de, steward of Cortés, 53

Gyves, Count Henri de, gold object presented by, 176

Hair-cord of feathers and gold, 58, 74

Hamy, E. T., cited, 19, 185, 214, 224

Hand of gold with tiger figure, 101; represented on feather-pieces, 85

Harpoons of featherwork, 24; of flint, 28. See Spears

Hat of featherwork, 77; of gold, 79

Hatchets of copper, 205; of gold, 17. See Axes

\section{AND MONOGRAPHS}




\begin{tabular}{|c|c|}
\hline 242 & GOLDSMITH'S AR'T \\
\hline & 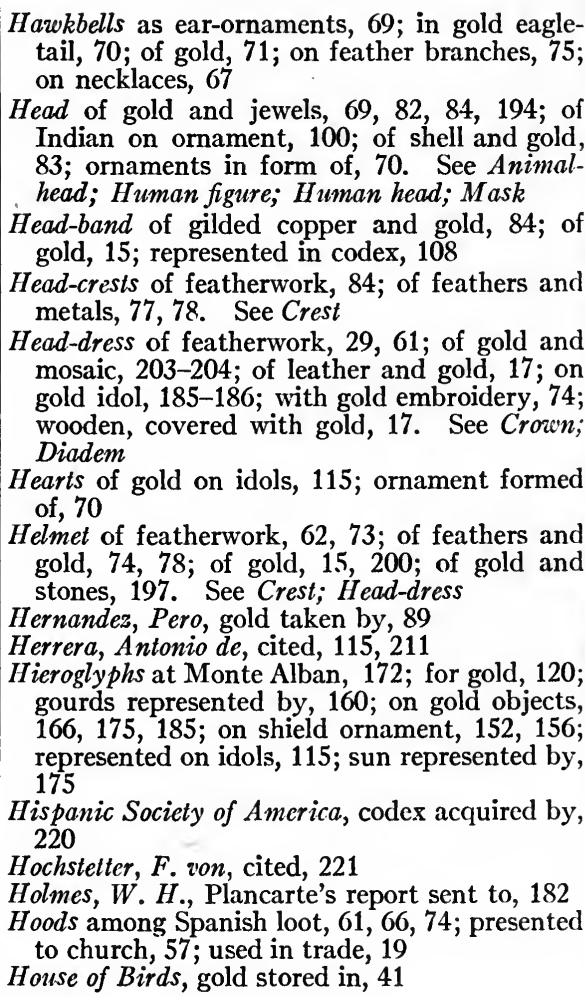 \\
\hline & INDIAN NOTES \\
\hline
\end{tabular}




\section{N D E X}

House of Commerce, King's objects delivered to, 86, 96, 195, 225. See Casa de Contratación Huajuapan, tomb found near, 144-145

Huaxayac, tribute paid by, 110

Huaxteca, butterfly an attribute of, 181

Huichilobos, temple of, 178

IInitsilopochlli, idol of, 114

Huitzo, gold ornaments from, 171, 172. See San Pablo Huitzo

Human face on gold ring, 145

Human figures of gold, 13-14, 185; on gold disc, $37,68,196$; represented in jewel, 148; represented on shield, 56-58, 76. See Idol

Human head of gold, 68, 69; represented on cup, 104. See Head

Human sacrifice by Aztecs, 118, 177, 213; corselet worn at, 56; knives used in, 18; preparations for, 34-35; represented on shield, 76

Humboldt, Alexander von, cited, 209-210, 220; Mexican paintings of, 158; on Aztec gold cup, 104

Hunter, Annie, codex copied by, 155

Icazbalceta, J. G., cited, 190, 193, 214

Idol adorned with breașt ornaments, 180; head

of gold, 176; lip-ornaments of, 173; of gold,

15, 16; ornamented with jewels, 114-115

Images sent to King, 98. See Human figures

Inventories of Spanish loot, 21-35, 56-102

Iron unknown to Middle America, 7-8

Iron age of Europe, 7

Itzlli, sandals ornamented with, 204

Ixtaltepec, gold object from, 176

Ixtlilxochitl, Fernando de Alva, cited, 213

\section{A N D MONOGRA PHS}




\begin{tabular}{|c|c|}
\hline 244 & GOLDSMITH'S ART \\
\hline & 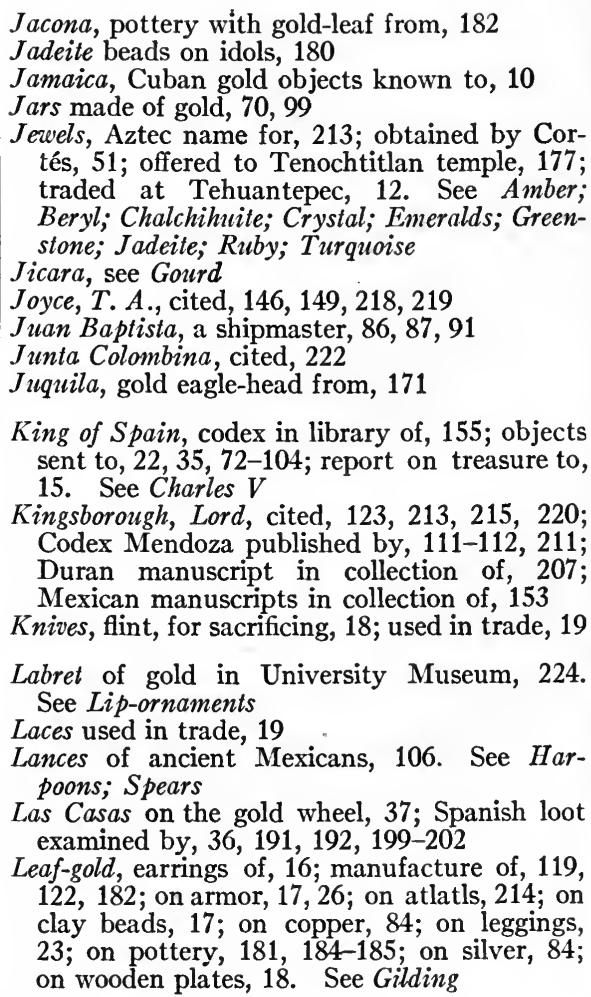 \\
\hline & INDIAN NOTES \\
\hline
\end{tabular}


Leaf-silver on leggings, 23

Leggings given to Spaniards, 23; of mosaicwork, 25

Leo X, Martyr's description dedicated to, 195

Leon, Francisco, gold objects in collection of, 175; on Aztec gold-working, 125

León, Juan Velásquez de, debt of, to King, 93

Leon, Nicolas, cited, 217, 222; gold object illustrated by, 164; mentioned, 125

Lion, heads of, in gold, 198; head of, on shield, 204; insignia of knights, 222; of gold, 16, 98; represented on mirror, 67

Lip-ornaments as tribute, 113; in gold object, 164; jeweled, 71, 72, 148; of gold, 172; of quartz and gold, 85; represented in codex, 108, 112. See Labret

Lizards of gold, 11, 72, 98, 198; teeth of, in gold necklace, 68

Lizas defined, 34

Locust, see Cicada

Lomayca, Juan de, gold taken by, 91

Loot obtained by Spaniards, 8-56. See Inventories

Lopez de Balbas, Pero, golden jewels taken by, 89 López de Gomara, see Gomara

Lorenzana, Archbishop, Tribute Roll published by, 108, 159, 210

Lothrop, $S$. K., drawing of jewel furnished by, 155

Loubat, Duc de, codex reproduced by, 161, 221; interest in Mexican codex, 154

Loubat Expedition, gold not found by, 144; grecque pattern found at Mitla by, 162

Lugo, Francisco de, Aztec treasure mentioned to, 45

\section{A ND MONOGRAPHS}




\begin{tabular}{|c|c|}
\hline 246 & GOLDSMITH'S ART \\
\hline & 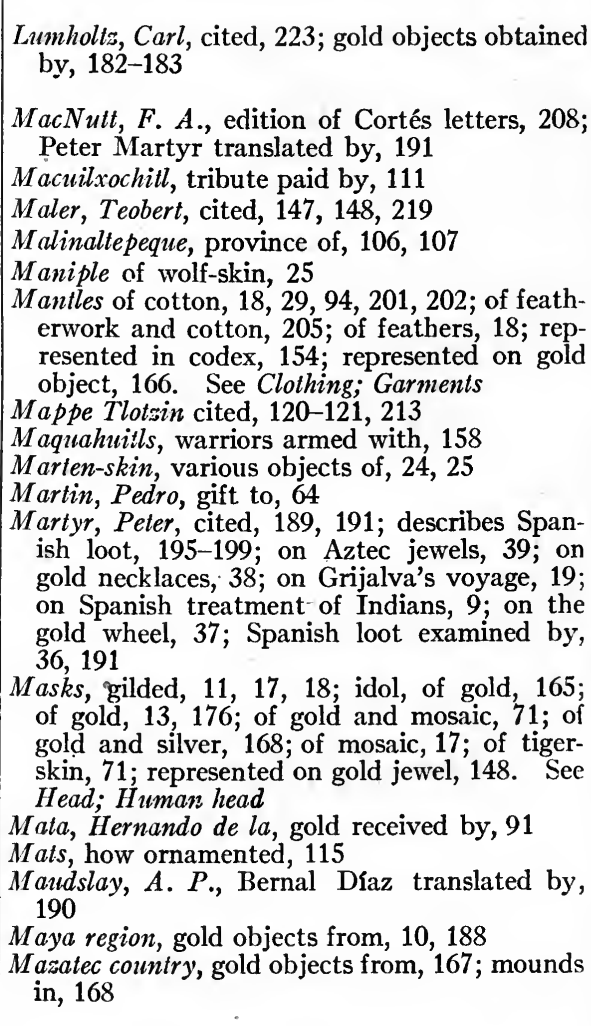 \\
\hline & I NDIAN NOTES \\
\hline
\end{tabular}


Mecatl defined, 213

Medals of gold, 201; of gold and jewels, 70-72, 81, 98; of gold on helmet, 73

Medellin, ornament for church in, 88

Medellin, Count de, gifts to, 66; gifts to grandson of, 66

Mejża, Gonzalo, King's treasurer, 49, 53

Men depicted on idols, 115. See Human figures; Idols

Mendoza, Alonso de, gold sent by, 92

Mendoza, L. T. de, cited, 209

Mendoza Codex, see Codex Mendoza

Miahuatlan, gold object found near, 173

Michapan, tribute paid by, 112

Michatlan, tribute paid by, 112

Michoacan, gilded pottery from, 182; gold objects from, 180, 184, 185

Mictlan, tribute paid by, 110

Mines, gold, in Mexico, 104-107

Mingoval, gifts to, 65

Mirrors adorned with gold, 16, 200-201, 205; of stone and gold, 198; on eagle figure, 59; sent to King, 67; used in trade, 19; with mosaic-work, 25

Miters of featherwork, gold, and stones, 205; of gold, 31; of gold and stones, 197; of mosaicwork, 24

Mitla, expedition to, 144; gold objects from, 170; grecque pattern from, 162; mosaic-work at, 162. See Mictlan

Mixteca, antiquities of, 144; bell from, 168; gold objects from, 168, 172, 174, 175, 188; tomb found in, 151

Mixtlan, tribute paid by, 112

\section{A ND MONOGRAPH}




\begin{tabular}{|c|c|}
\hline 248 & GOLDSMITH'S ART \\
\hline & 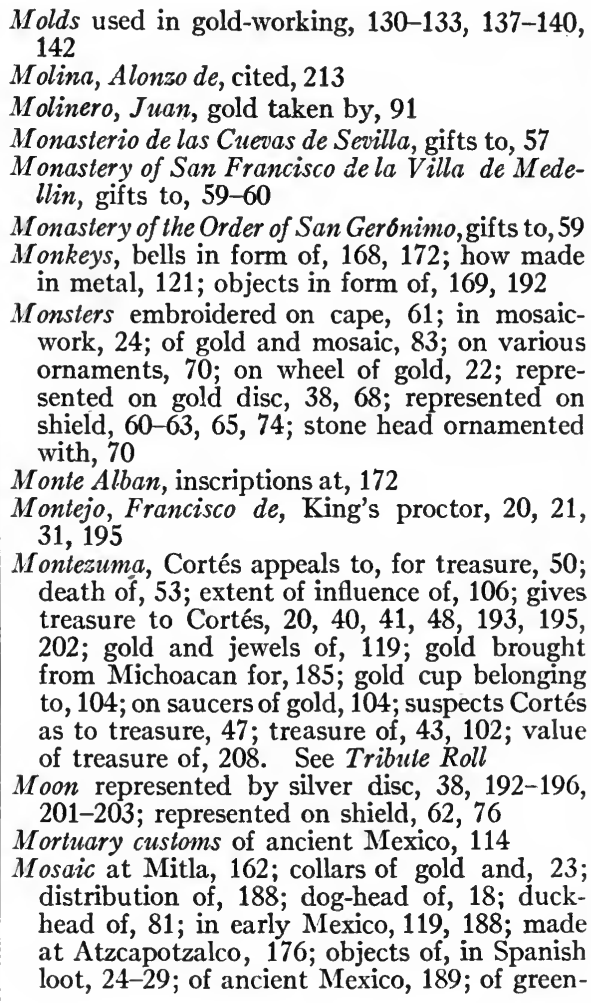 \\
\hline & INDIAN NOTES \\
\hline
\end{tabular}




\section{N D E X}

stone on monster, 83 ; of blue store, 24 ; of feathers, 72, 73, 78; of mother-of-pearl, 115; of pearls, 205; of turquoise on ornament, 152; on armor, 17; on gold objects, 224; on helmet, 204; on idols, 114; on masks, 17, 18, 71 ; on shield, 75, 76, 79; on shield ornament, 156; staff made of, 62; specimens of, ęxtant, 103. See Featherwork

Moscador defined, 33

Mosqueador defined, 33

Mother-of-pearl, mosaic of, 115. See Pearls Motolinia, see Toribio de Motolinia

Mozetta of feathers and gold, 74; of featherwork, 61, 73. See Cape

Mulberries of gold on head-crest, 77

Muñoz, Juan Bautista, on Spanish loot, 21, 32

Museo Mexicana, finger-rings illustrated in, 145

Museo Nacional, Mexico, gold objects in, 150, 164, 176, 185; Mexican painting in, 158-159; shield in, 103; Sologuren collection purchased by, 144; Tribute Roll in, 210

Museo Nazionale, Florence, gilded atlatls in, 214

Nadaillac, Marquis de, cited, 219

Nahuan region, gold objects from, 176-181

Narvaez, Pamfilo de, with Cortés, 54

National Museum of Mexico, see Museo Nacional Navarrete, M.F. de, cited, 206

Navarro, Joaquin, Prescott translated by, 208

Necklaces, Aztec name for, 213; for greyhounds, 71 ; gold, given Grijalva, 11; of beads used in trade, 19; of gold, 11-13,16, 17, 38, 192; of gold and jewels, 194, 201, 203; of greenstone and gold, 71; on idols, 15, 180; sent to King, 97, 98; with bollones, 67

\section{A N D MONOGRAPHS}




\begin{tabular}{|c|c|}
\hline 250 & GOLDSMITH'S ART \\
\hline & 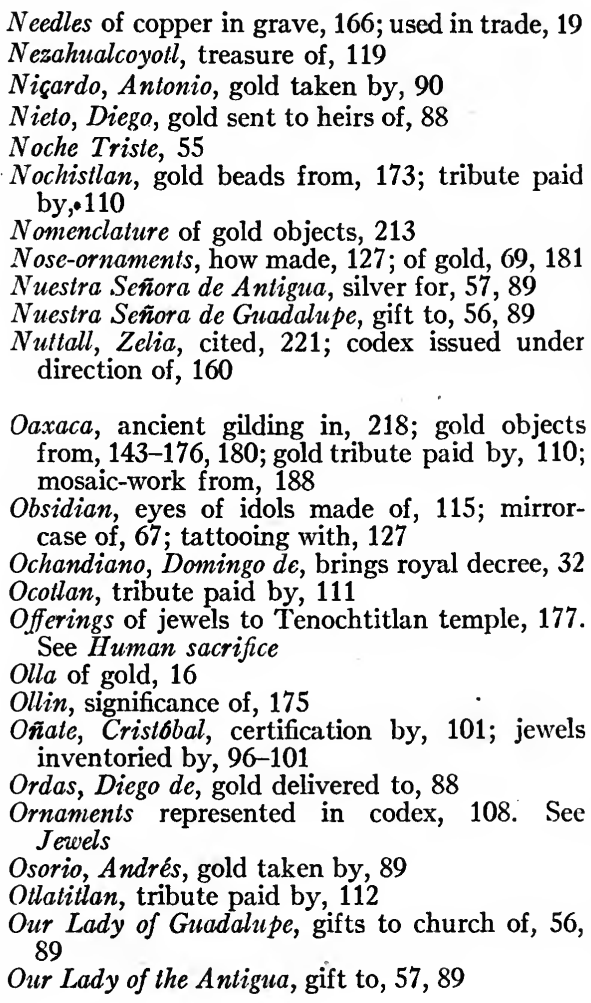 \\
\hline & INDIAN NOTES \\
\hline
\end{tabular}


Oviedo y Valdés, J. F. de, cited, 190, 206-207; loot examined by, 36, 191, 194-195; on gilding in Central America, 217; on Grijalva expedition, 14-15; on the gold disc, 37

Owl of gold, 97; on gold rings, 99; represented on mirror, 67; represented on shield, 62

Oicl-head in gold, 171-172; on shield, 204

Oxitlan, tribute paid by, 112

Ozomalli, significance of, 172. See Monkeys

Pablo, cabin-boy, gold taken by, 91

Pacheco, Luis, gifts to, 64-65

Padilla, Garcia de, gifts to, 63

Papantla, gold jewel from, 185; ruins of, 224

Parrot of feathers and gold, 62; of gold, 85

Paso y Troncoso, Francisco, cited, 43, 124, 154, 156, 219

Patena defined, 33

Peabody Museum, codex in, 155, 220

Pearls among Spanish loot, 200; consigned to King, 89; in serpent ornament, 100 ; mosaicwork of, 205; offered to Tenochtitlan temple, 177; scepter decorated with, 204; shields ornamented with, 205. See Mother-of-pearl

Pena, Juan de la, letter to, on Spanish loot, 194

Peñafiel, Antonio, cited, 212, 218-225; gold objects illustrated by, $145, \cdot 164,169$; on Aztec gold objects, 176; on Zapotec tribute, 111; Tribute Roll reproduced by, 108, 210

Pendants of gold, 23, 166, 197; on carnicles, 67; on eagle-head ornament, 149; on earrings and necklaces, 33; on gold eagle, 83 ; on gold necklaces, 38-39, 67, 201, 203; on gold ornaments, $85,98,148-150$; on jeweled head, 84 ; on medal, 100; on shield ornament, 156; sent to King, 99, 101

\section{A N D MONOGR A P H S}




\begin{tabular}{|c|c|}
\hline 252 & GOLDSM I TH'S A R T \\
\hline & 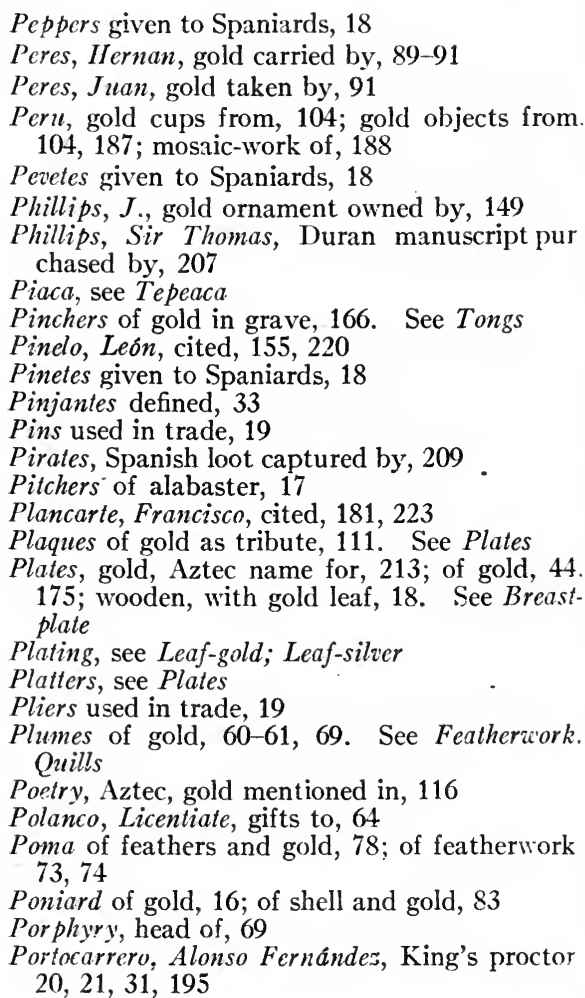 \\
\hline & I N IA N NOTES \\
\hline
\end{tabular}


Portocarrero, Juan, see Puerto-Carrero

Potonchan, barter with Indians of, 15

Pottery found in tomb, 147; ornamented with gold, 181, 183-184; scraper of, in gold-working, 136

Pouch of gold network, 52. See Bags

Prescott, W. H., cited, 206, 208

Pueblo Viejo, mounds near, 167; tomb found in, 151

Puertocarrero, see Portocarrero

Puerto-Carrero, Juan, gifts to, 66

Puetlan, tribute paid by, 112

Pujantes, defined, 33

Pulque, see God of Pulque

Pyrites, eyes of idols made of, 115

$P y x$ sent to King, 69, 97

Quartz, lip-ornaments of, 85

Quauhtli defined, 171. See Eagle-head

Quaxaca, Spanish party sent to, 143. See Oaxaca

Queen of Spain, objects sent to, 22, 35, 72-104

Quetzalcoatl., goldsmiths' art improved by, 117

Quetsal-feathers on shield, 159

Quicksilver used in gilding, 217-218

Quills covered with gold, 28; gold kept in, 107; of gold, 16, 58, 62, 78, 82. See Feathers

Quimbayas, gold objects from, 187

Quiñones, Antonio de, King's proctor, 72, 86, 87, 90, 91, 209

Ramirez, J. F., Duran manuscript annotated by, 207; on value of Aztec treasure, 48; Prescott annotated by, 208

Rapiers adorned with gold, 78; sent to King, 97

\section{A N D M O NOGRAPHS}




\begin{tabular}{|c|c|}
\hline 254 & GOLDSMITH'S A RT. \\
\hline & 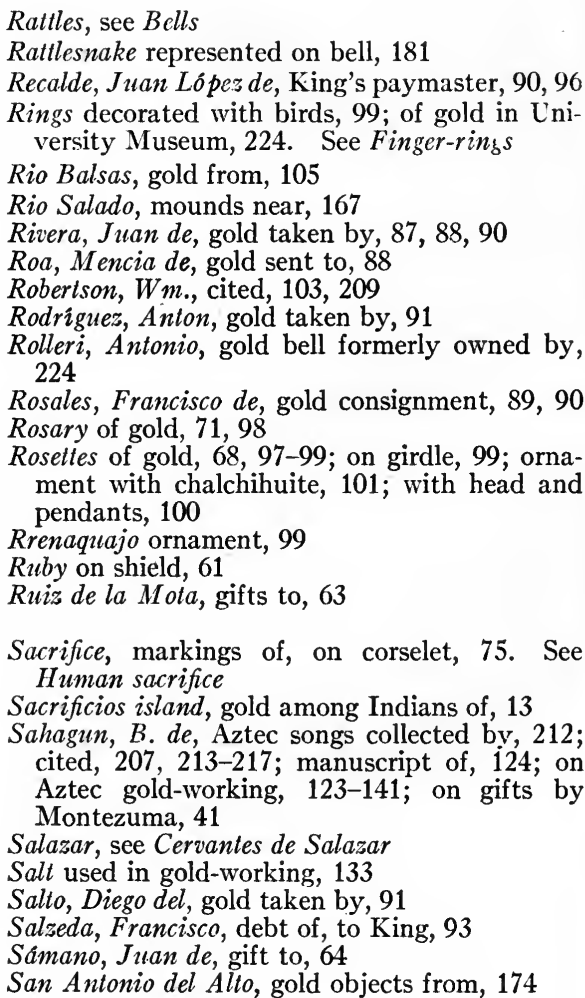 \\
\hline & I N I A N NOTES \\
\hline
\end{tabular}


Sanchez, Ambrosio, voyage of, 33

Sanchez, Matheo, gold taken by, 91

Sancti Spiritus, a caravel, 209

Sand used in gold-working, 136

Sandals of skin and gold, 200, 204; sewn with gold thread, 25; used in trade, 19. See Shoes

San Francisco de Cibdad de Real, gifts to, 58-59

San Francisco de Medellin, silver for, 89

San Jerónimo, island of Española, 22

San Juan de Ulia, barter with Indians of, 15

San Pablo Huitzo, gold objects from, 175. See Huitzo

San Salvador de Oviedo, gifts to, 60

San Sebastian, gold jewels in tomb at, 147

Santa Clara de Tordesillas, gifts to, 60

Santa María de la Rábida, a ship, 86, 87, 91

Santiago, Licentiate, gift to, 64

Santiago de Galicia, gifts to, 60-61

Santo Domingo, Cuban gold objects known to, 10 Santo Tomás de Avila, gifts to, 58

Sargent, Homer E., gold ring possessed by, 145

Saucers of gold, 16, 104-107

Saville, M.H., cited, 190, 191, 211, 222, 223

Scallop-shells of silver, 76; ornaments of, 82-83

Scepter of gold, 204; of mosaic-work, 24, 27, 198

Scissors used in trade, 19

Scorpion represented on ornament, 100

Scrapers used in gold-working, 136

Seeds sacrificed to Tenochtitlan temple, 177

Seler, E., Aztec song published by, 212; bell collected by, 168; cited, 220, 223; copy of Kingsborough codex given to, 154; on Aztec poetry, 116-117; on gold found in excavation, 179; on Mexican goldwork, 141-142, 215-217; Sahagun chapters published by, 124

\section{A N D MONOGRAPHS}




\begin{tabular}{|c|c|}
\hline 256 & G OLDSMITH'S ART \\
\hline & 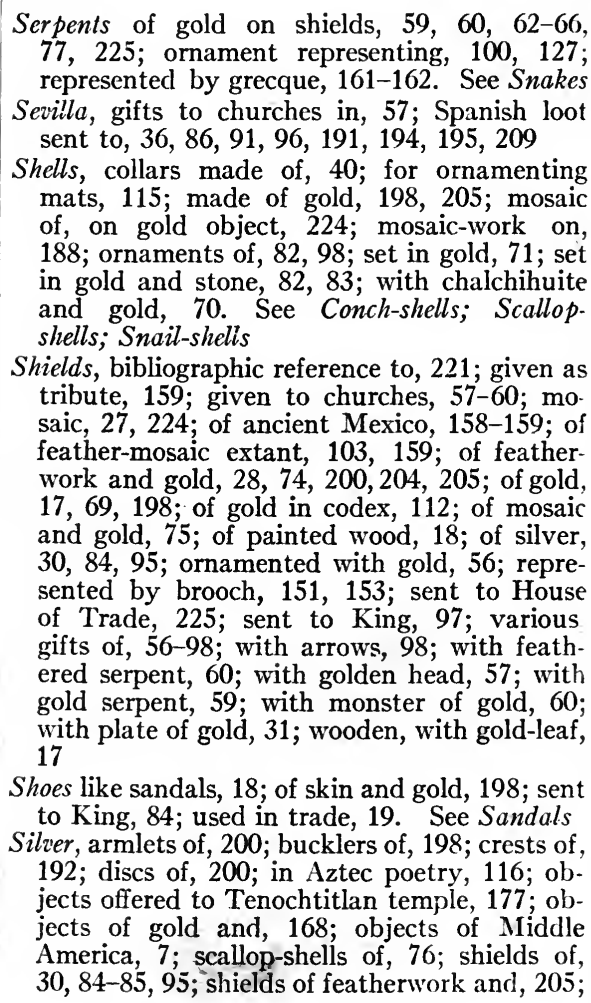 \\
\hline & INDIAN NOTES \\
\hline
\end{tabular}




\section{N D E X}

turtles of, in grave, 166; various objects of, 30, 165; wheel of, in Spanish loot, 30, 35-33, 192-196, 201-203; worked by Aztecs, 133-134 Skins of birds and animals, 204; painted red, 18 Skull of gold in grave, 166. See Death's head Slaves sold by Spaniards, 93

Snail-shells as ear-ornaments, 69; flowers of, 71; of gold, 69; of gold in necklace, 68; of gold on shield, 60, 62, 64; with greenstone, 71 . See Shells

Snakes, ears represented by, 69; head of, on forehead of image, 69; lip-ornaments shaped like, 85; mosaic scepter in form of, 27; represented in gold, 100, 101, 193; represented on idols, 115. See Serpents

Society of Antiquaries, gold cup exhibited to, 104 Soconusco, tribute paid by, 113

Soldering by gold-workers, 141

Sologuren, objects in collection of, 144, 150-152, 169-175

Sombrerito, tomb found at, 144-145

Songs of ancient Mexicans, 212

Soto, Diego de, objects of gold sent by, 66, 76-79 So:rres of gold, 14, 104-107

South America, gold objects from, 181, 184 Spades of copper, 205 .

Spaniards represented in codex, 154

Spears of gold and featherwork, 198. See Harpoons; Lances

Spindles of gold, 71

Spoons of gold, 71; used in gold-working, 140-142 Staff of gold, 79; of mosaic-work, 62

Standard of wolf-skin, 25

Sletson, J. B., Duran manuscript in collection of, 207

\section{A N D M ONOGRAPHS}




\begin{tabular}{|c|c|}
\hline 258 & GOLDSMITH'S AR T \\
\hline & 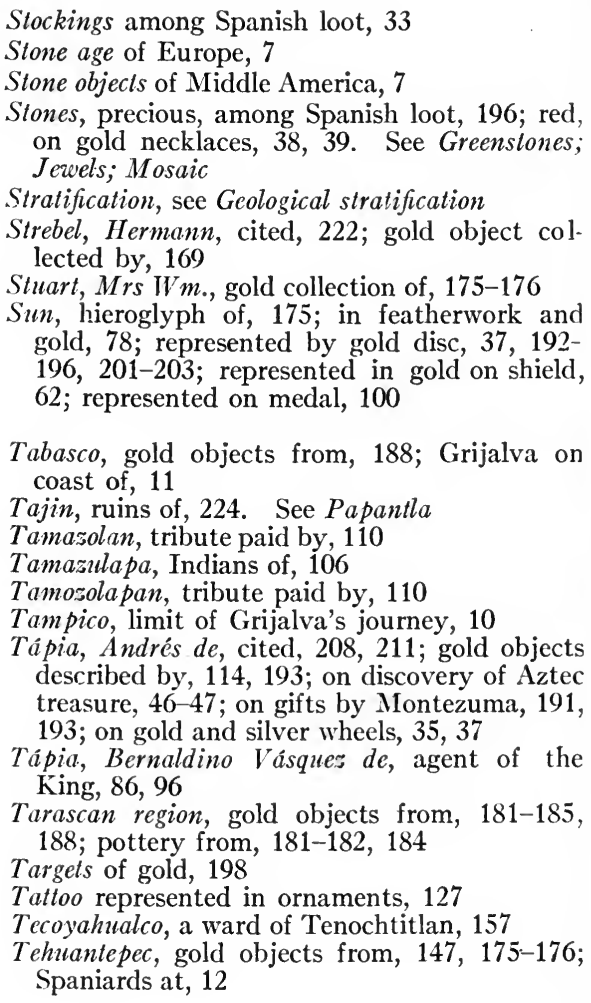 \\
\hline & I N D A N NOTES \\
\hline
\end{tabular}


Temixtillan, gold sent from, 92; shields from, 85 ; silver shields from, 95; war in, 93

Temple of the Columns, mosaic-work in, 162

Tendile, gifts sent through, 20. See Teudilli

Teniz, Spaniards explore, 106

Tenochtitlan, a market for treasure, 118-119; ancient site of, 178; exchange of gifts at, 40; gold objects received at, 195; jewels registered at, 97; temple of, 176-178; tribute to chiefs of, 108; wards of, 157

Tenuxtitan, see Tenochtitlan

Teocuitlacomalli defined, 180, 213

Teocuitlacoyolli defined, 213

Teocuillamaquistli defined, 213

Teocuislamecatl defined, 213

Teocullan, tribute paid by, 111

Teotillan, gold objects from, 169; mask from. 168; tribute paid by, 112

Teotitlan del Camino, gold objects from, 165

Tepaneco, the, as goldsmiths, 117

Tepeaca, sale of slaves of, 93-94

Tepetetlaostoc, codex pertaining to, 153, 219

Tepic, gold objects from, 182, 184, 185

Tepito, gold tooth from, 185

Tepuscululan, tribute paid by, 110

Teteutlan, tribute paid by, 112

Tetipac, tribute paid by, 111

Teudilli, gold and silver wheels given by, 203 . See Tendile

Teuhcalco, Aztec wealth stored in, 41

Teuhtlile, see Tendile; Teudilli

Texcoco, see Tezcuco

Texopan, tribute paid by, 110

Tezcallipoca, Aztec deity, 180

\section{A N D MONOGRAPH S}




\begin{tabular}{|c|c|}
\hline 260 & GOLDSMITH'S ART \\
\hline & 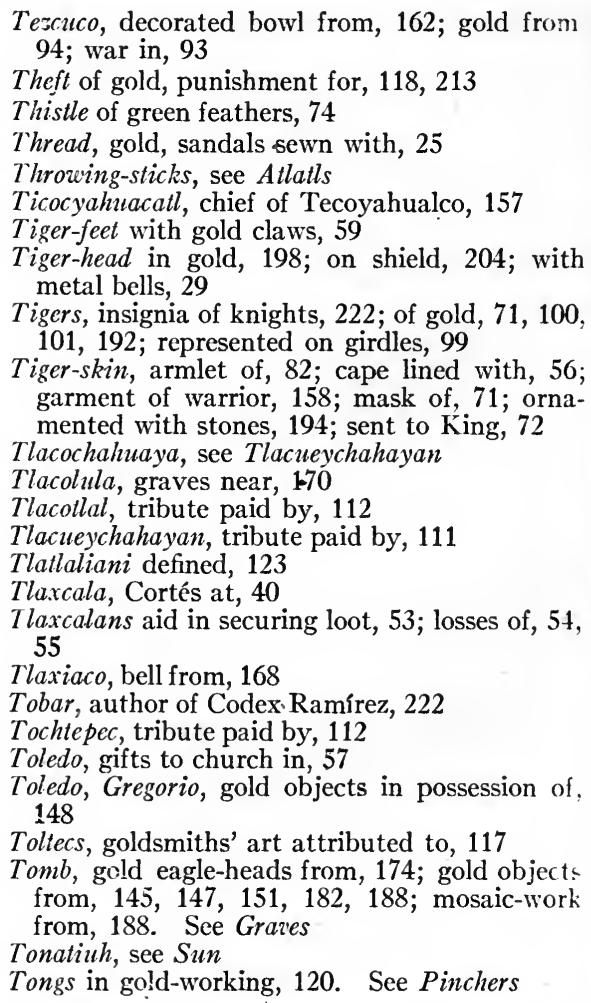 \\
\hline & I NDIAN NOTES \\
\hline
\end{tabular}


Tooth, human, in gold, 174, 185

Tooth-picks of gold, 101

Tordesillas, Indian girls at, 32

Toribio de Motolinia, cited, 121-122, 214

Torquemada, Juan de, cited, 122-123, 214

Torres, Antonio de la, gold consigned to, 90

Torres, Juan de, gold consigned to father of, 89

Tortoise-shell, fan of, 60

Totonaca, gold objects from region of, 169, 185186

Tototepec, tribute paid by, 112

Tostlan, tribute paid by, 112

Tozzer, A. M., acknowledgment to, 155

Trade, objects used in, 19; with Indians at Tehuantepec, 12; with Mexican coast Indians, 15

Trees represented on blowguns, 52; represented on carnicles, 67; represented on gold disc, 196 Tribute exacted by Spaniards, 219; levied by Montezuma, 158; of gold in Mexico, 108; represented in codex, 154

Tribute Roll of Montezuma, 108; certain designs in, 157-159; copies of, 210

Troncoso, see Paso y Troncoso

Trumpet, golden, in Aztec poetry, 116

Tubes, cane, gold kept in, 107, 108

Tuchitepeque, gold from, 107

Tulteca defined, 123

Turkey represented on pottery, 183

Turkey-feathers, fan made of, 58

Turquoise, earrings ornamented with, 16; from Tepic, 183; in Aztec poetry, 116; mosaic of, $18,152,224$; necklace of, 71 ; set in gold, 52; used on rings, 99

Turtle-bone in fan, 78

\section{A N D M O N O G A P H S}




\begin{tabular}{|c|c|}
\hline 262 & GOLDSM I T H'S A R T \\
\hline & 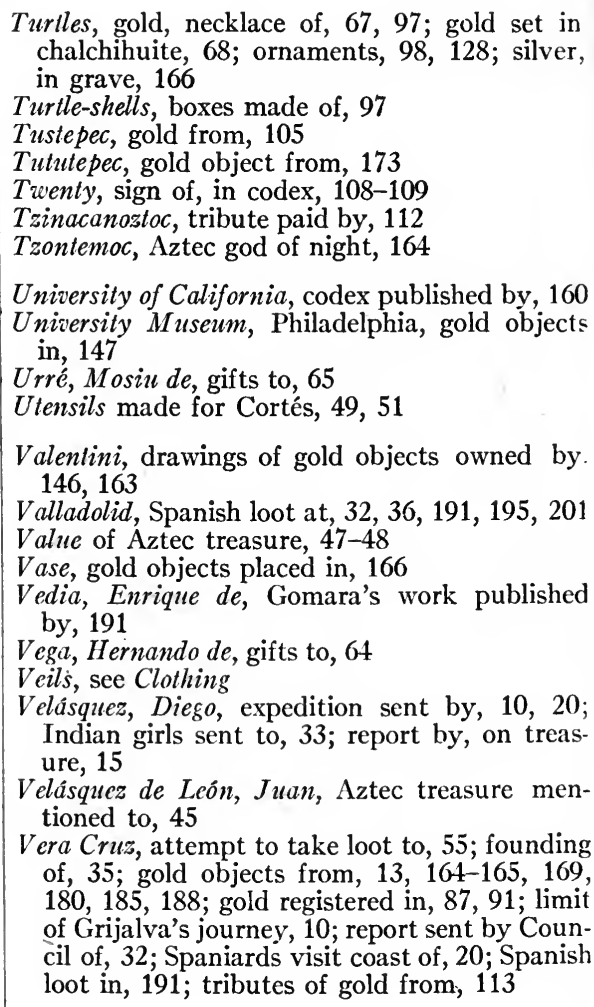 \\
\hline & - INDIAN NOTES \\
\hline
\end{tabular}


Veret, Luis, delivery of loot to, 32

Vergara, Alonso de, a notary, 86-87, 90

Verjitas defined, 34

Vessels of gold among Aztec treasure, 44

Vetancurt, Agustin, cited, 213

Vitcilopuchtli, God of Battles, 204

Warriors, insignia of, 171

Wax used in gold-working, 126, 129, 130, 137140,142

Weasels represented in ornaments, 97-100

Wheels of feathers, 31; of gold and silver, 22, 30, 35-38, 192-196, 201-203; of gold on featherpiece, 60; of gold on helmet, 78; of gold on shield, 62-64, 66; of silver, 30, 38; on gold eagle ornament, 149; on- silver strip, 84; with gold embroidery, 74 . See Discs

Wildcat-skins lined with cotton, 29

Williams, Helen Maria, Humboldt translated by, 210

Wolf-heads in gold, 198; with metal bells, 29

Wood, mosaic-work on, 188

Worms of gold for pendants, 101

Wristguards sent to King, 84

Xaltepec, tribute paid by, 110

Xayaca, tribute paid by, 112

Xicales, see Gourds

$X$ icaltepec, tribute paid by, 112

$X i p e$ Totec, a deity, 109, 116, 118, 213

Yaca papalotl defined, 181

Yaca vicolli defined, 181

Yancuitlan, tribute paid by, 110

Yañes, Alonso, discovers Aztec treasure, 45

\section{A N D M ONOGRAPHS}




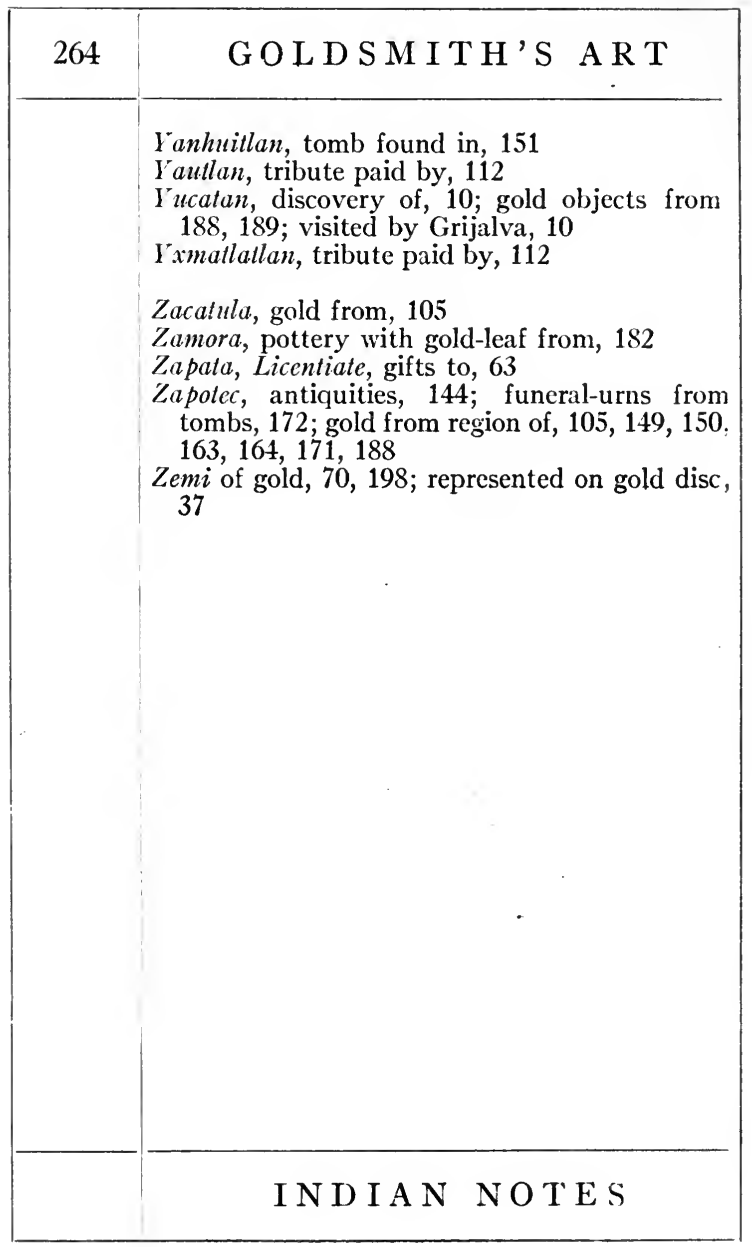







\section{N D I A N NOTES}

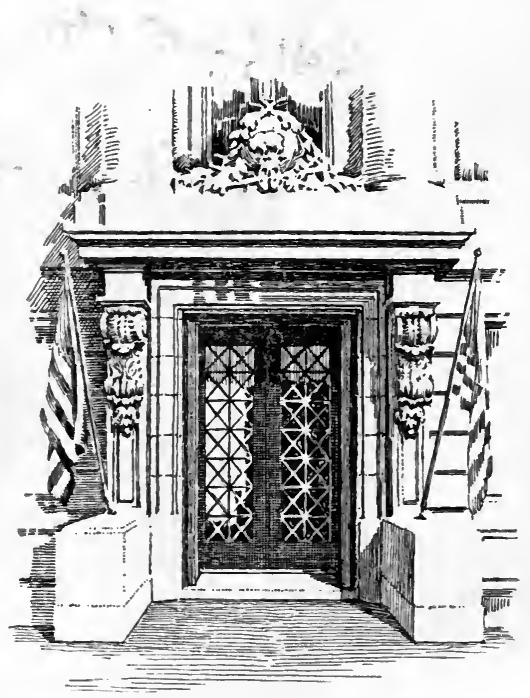




\section{PLEASE DO NOT REMOVE}

CARDS OR SLIPS FROM THIS POCKET

\section{UNIVERSITY OF TORONTO LIBRARY}


